AFGHANISTAN IN 2010

\title{
A Survey of the Afghan People
}
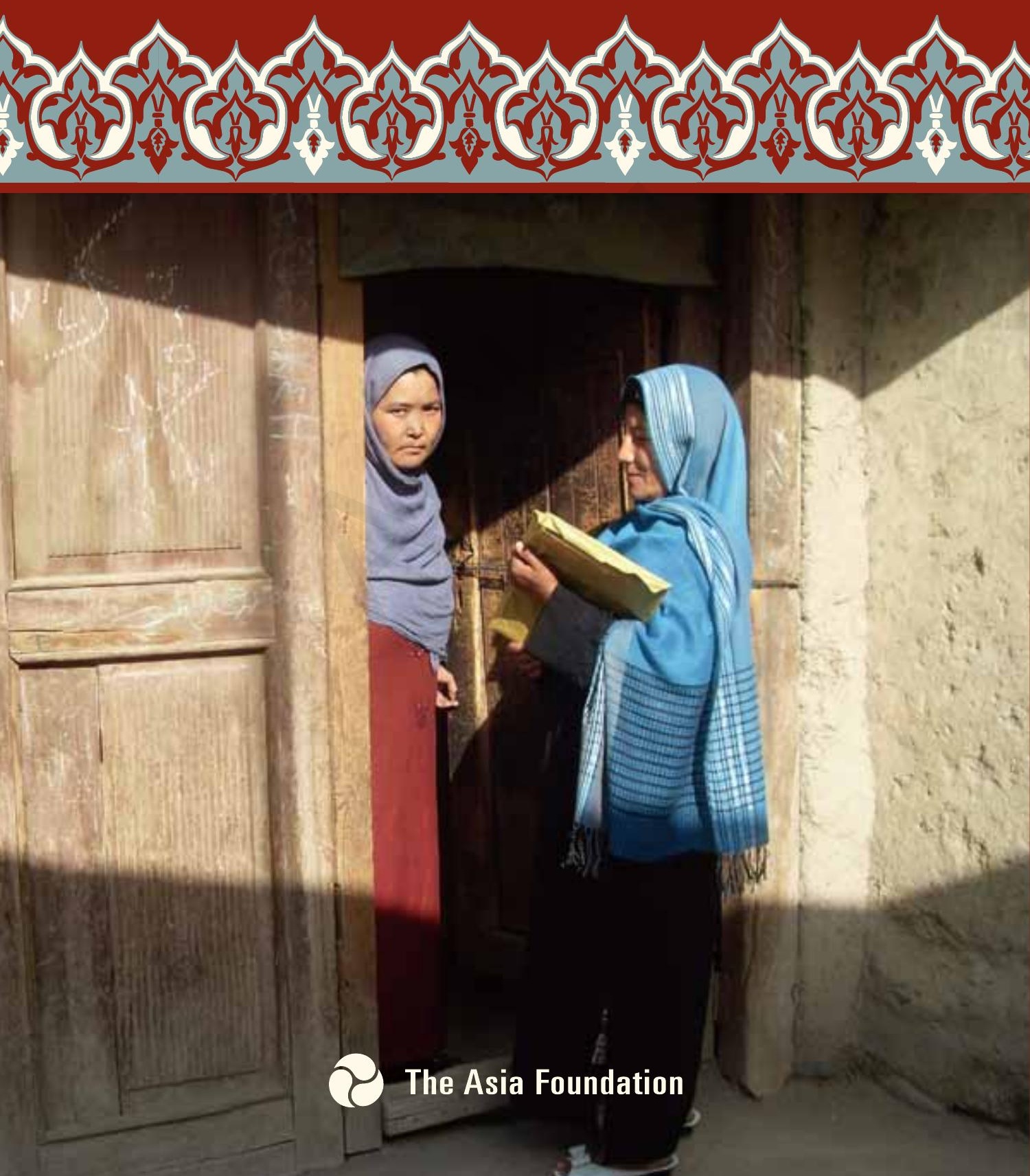


\title{
AFGHANISTAN IN 2010 \\ A Survey of the Afghan People
}

\author{
The Asia Foundation
}




\title{
Afghanistan in 2010 \\ A Survey of the Afghan People
}

\section{Project Design and Direction}

The Asia Foundation

\author{
Editor \\ Ruth Rene
}

Report Authors

Mohammad Osman Tariq

Najla Ayoubi

Fazel Rabi Haqbeen

\section{Fieldwork \\ Afghan Centre for Socio-economic and Opinion Research (ACSOR), Kabul}

\section{Report Design and Printing}

The Asia Foundation

AINA Media, Kabul

(C) 2010, The Asia Foundation

\begin{abstract}
About The Asia Foundation
The Asia Foundation is a non-profit, non-governmental organization committed to the development of a peaceful, prosperous, just, and open Asia-Pacific region. The Foundation supports Asian initiatives to improve governance, law, and civil society; women's empowerment; economic reform and development; sustainable development and the environment; and international relations. Drawing on nearly 60 years of experience in Asia, the Foundation collaborates with private and public partners to support leadership and institutional development, exchanges, and policy research.

With 18 offices throughout Asia, an office in Washington, DC, and its headquarters in San Francisco, the Foundation addresses these issues on both a country and regional level. In 2009, the Foundation provided more than $\$ 86$ million in program support and distributed nearly one million books and journals valued at over $\$ 43$ million.
\end{abstract}

The Asia Foundation is not an endowed organization, and depends solely on monetary contributions from donors to accomplish its work.

For more information, visit www.asiafoundation.org

This survey was made possible by support provided by the U.S. Agency for International Development (Award No. 306-A-00-09-00514-00). The opinions expressed herein do not reflect the views of the U.S. Agency for International Development. 


\section{Table of contents}

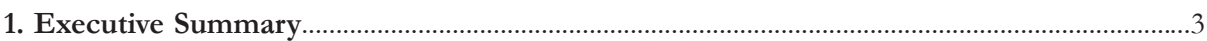

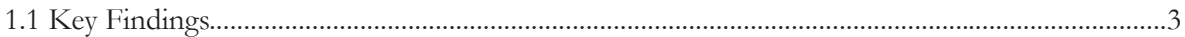

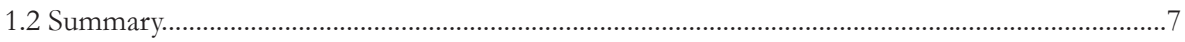

1.3 Restriction on survey field work and replacements of sampling points for security reasons........14

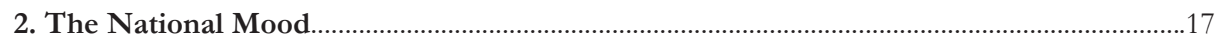

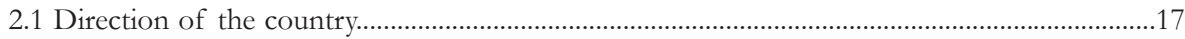

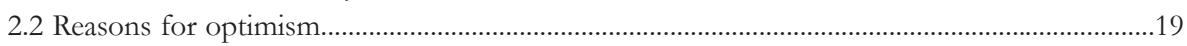

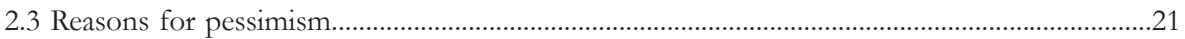

2.4 Afghanistan's biggest problems: National level........................................................................23

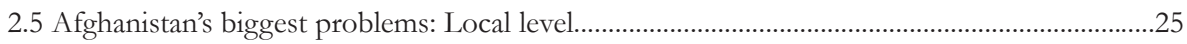

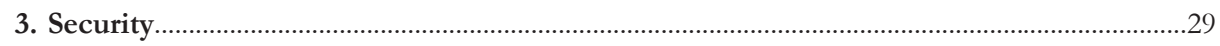

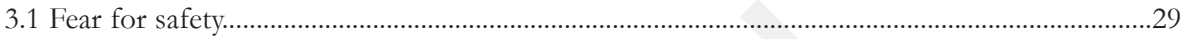

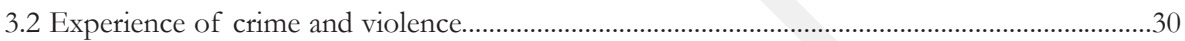

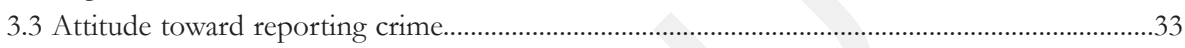

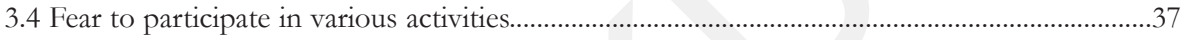

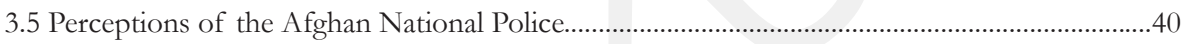

3.6 Perceptions of the Afghan National Army......................................................................................42

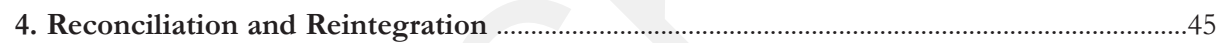

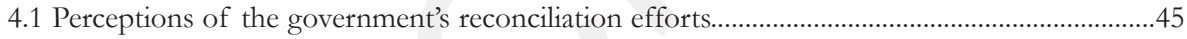

4.2 Sympathy with armed opposition groups......................................................................................4

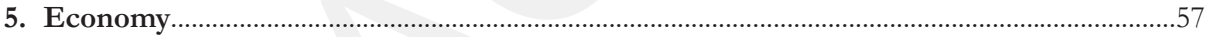

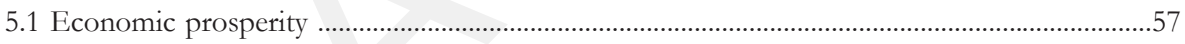

5.2 Household situation over the last year..............................................................................................59

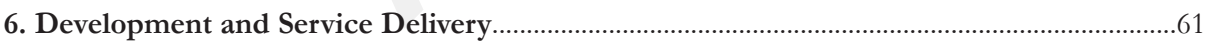

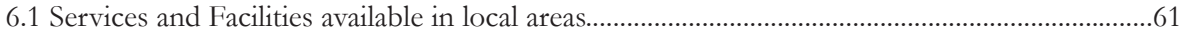

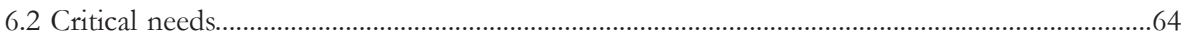

6.3Awareness of development programs.............................................................................................65

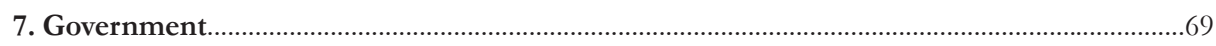

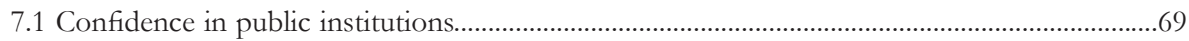

7.2 Satisfaction with the performance of the central government.....................................................

7.3 Satisfaction with central government performance in policy and service delivery....................73

7.4 Important achievements and failings of the central government ...............................................76

7.5 Satisfaction with the performance of local government...............................................................79

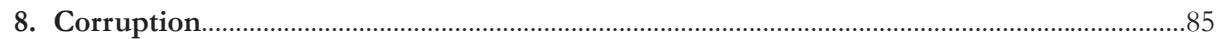

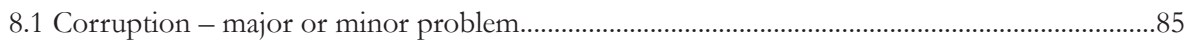

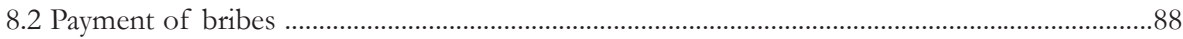




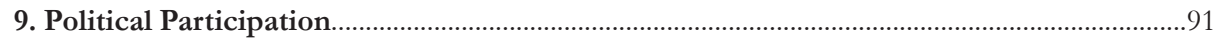

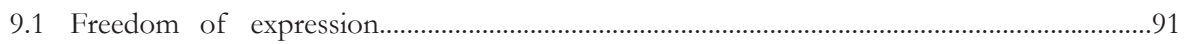

9.2 Personal Efficacy: ability to influence government decisions.....................................................96

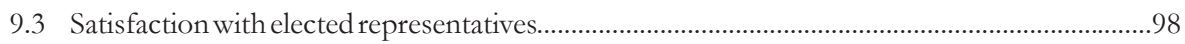

9.4 Consideration of the public interest when making decisions and policies...............................100

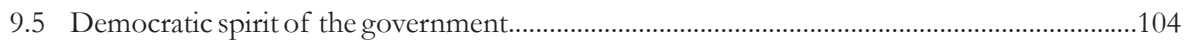

9.6 Attitudes toward participation in democratic processes .............................................................108

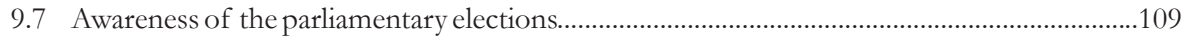

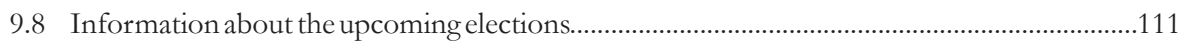

9.9 Intention to vote in the 2010 parliamentary elections...............................................................112

9.10 Perceptions of the 2009 presidential elections..................................................................116

9.11 The Afghan government's ability to conduct elections and the involvement of the international community......

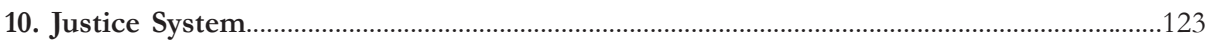

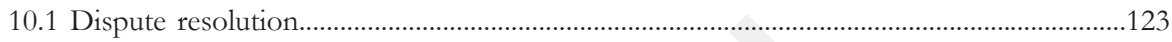

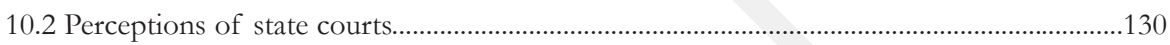

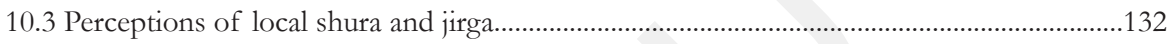

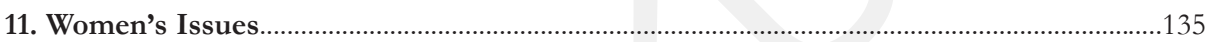

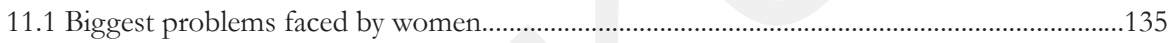

11.2 Attitudes toward gender equality: women and education.......................................................137

11.3 Attitudes toward gender equality: women and employment.................................................139

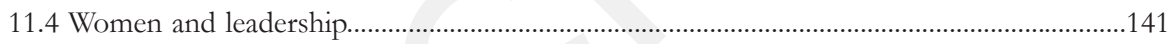

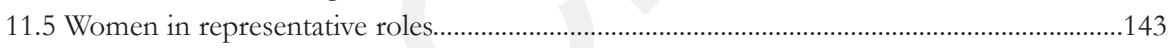

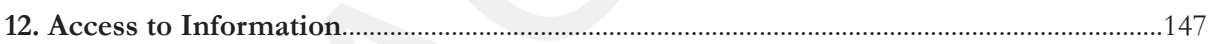

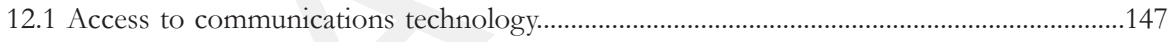

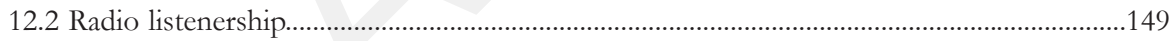

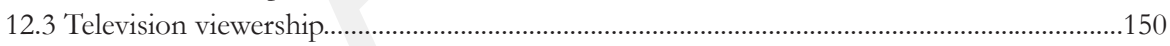

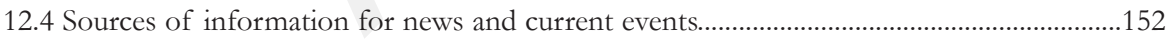

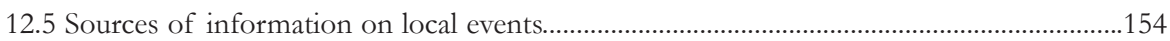

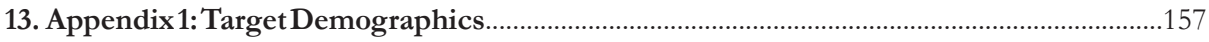

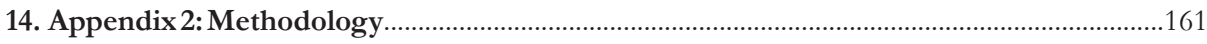

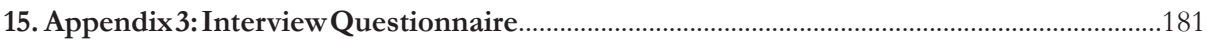

16. Appendix 4: Afghanistan Provincial and Regional map..........................................................226 


\section{Preface}

2010 has been a critical year in and for Afghanistan. The 12 months since the last survey have been filled with historic events and significant challenges. Aiming to provide policy makers and influential actors in government, civil society, the international community, and the broader Afghan citizenry with useful, actionable information, the 2010 Survey of the Afghan People presents a comprehensive overview of national perceptions in a number of key policy areas, including security, economy, governance, democratic values, and women and society. Expanding from its limited scope in 2004, and building upon previous surveys conducted in 2006, 2007, 2008, and 2009, the 2010 survey continued tracking core areas of interests, while also adapting the questionnaire to the current landscape and strengthening methodology to address current constraints and challenges. The survey's value is in its consistent reliability in measuring public perception systematically in each passing year, making it an important public policy tool and "snapshot" barometer of public opinion in Afghanistan.

The 2010 survey, like the previous ones, employed a standard questionnaire designed to solicit actionable responses from typical Afghans which would prove useful to policy makers, social researchers, as well as donor organizations in their own assessments and planning. In addition to core tracking questions included in the questionnaire since the survey's initial inception in 2004, The Asia Foundation consulted

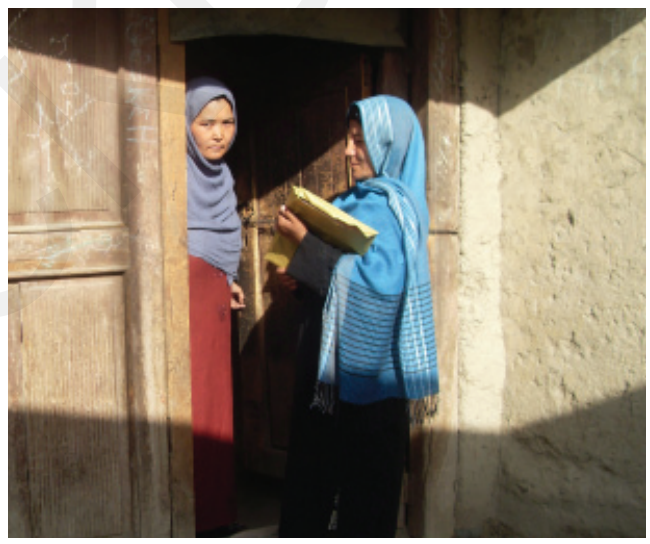

Field surveyer in Kabul; preparing to start interview administeration experts, stakeholders, and donors for review and suggestions for new assessment elements in 2010. This is reflected in the survey through a greater emphasis placed on the areas of sub-national governance, economy and development, women and society, and democratic values.

Operationally, 634 field surveyors throughout all 34 provinces of Afghanistan interviewed 6,467 adult Afghans between June 18 and July 5, to construct 2010 Survey data sets. Sample points were randomly distributed proportional to geographical and residential characteristics, with Kish grids used to select individual respondents within households. Instability, presence of active fighting, logistical constraints, and 
natural impediments in some provinces caused a number of sampling points to be tactically adjusted or replaced in order to keep interviewers out of harm's way and able to conduct their interviews. Full details on the methodology of the survey are available in the Appendix 2 of this report. The survey questionnaire, with percentage of responses by each question, can be found in Appendix 3 .

The survey also represents the most visible product of a comprehensive approach by The Asia Foundation to build Afghan research capacity. Although the survey was commissioned, developed, and managed by the Foundation's Afghanistan office, several Afghan organizations benefited from the partnerships forged by the program. Fieldwork was conducted by the Kabul-based Afghan Center for Socioeconomic and Opinion Research (ACSOR), which has received support from The Asia Foundation since 2006. An internship program to build capacity for students and serve the broader Afghan research community was continued from 2008 in partnership with the National Centre for Policy Research (NCPR) at Kabul University. In addition to specialized trainings, selected students completed projects and received practical hands-on work experience through placements with various research organizations. The Asia Foundation also offered specialized training on statistical tools for personnel from the Afghan Government's Central Statistic Organization (CSO). Further internships and trainings are planned for later this year.

In addition, this year, three members of our Afghan staff wrote up the full survey report: Mohammad Osman Tariq, Najla Ayoubi and Fazel Rabi Haqbeen. Four Foundation colleagues, including, Jehangir Gabar, the survey manager traveled to Nepal to receive training from Asia Foundation partners who had written the survey in previous years, Sudhindra Sharma and Pawan Sen from the Interdisciplinary Agency (IDA), who also facilitated this year's write-up process by providing basic structure in the form of a preliminary draft. Ruth Rennie, consultant to the Foundation, also provided editorial support, as she did last year. In Afghanistan Mr. Jehangir Gabar managed the overall aspects of the project including preparing annexes and composing the report for the printing. Ms. Sheilagh Henry and Mr. Zoran Milovic provided overall guidance and support to the project.

Finally, the generous support and confidence of the United States Agency for International Development (USAID) and its team of professionals - particularly Mr. Mir Waez Zarif - made this important research and capacity building tool possible.

The Asia Foundation

Kabul, Afghanistan

October 2010 


\section{Executive Summary}

\subsection{Key Findings}

In $2010,47 \%$ of respondents say that the country is moving in the right direction. This figure has been increasing since 2008 (38\%) and 2009 (42\%).

The main reason cited for optimism continues to be the perception of good security, mentioned by $38 \%$ of respondents who say the country is moving in the right direction. This number has decreased from 44\% in 2009. A little more than a third of respondents in 2010 also cite construction and rebuilding (35\%), and opening of schools for girls $(15 \%)$ remains the third reason for optimism in 2010, although this has decreased from $21 \%$ in 2009 .

Insecurity also remains the main reason for pessimism, cited by $44 \%$ of respondents who say the country is moving in the wrong direction. The proportion of respondents that highlight insecurity in 2010 has increased slightly from $42 \%$ in 2009 . The proportion of respondents who identify corruption as a reason for pessimism has increased significantly to $27 \%$ in 2010 from 17\% in 2009. The other main reasons for pessimism identified by respondents include bad government (18\%) and unemployment $(16 \%)$.

Insecurity (including attacks, violence and terrorism) is also identified as the biggest problem in Afghanistan by over a third of respondents (37\%), particularly in the South East (51\%), West (43\%) and South West (42\%). Unemployment remains the second biggest problem, mentioned by $28 \%$ of respondents. Corruption is identified by $27 \%$ of respondents making it the third biggest problem in 2010 , and marking a significant increase from 2009 when it was mentioned by $17 \%$. A poor economy $(11 \%)$, lack of education (11\%) and poverty (10\%) also continue to be identified amongst Afghanistan's biggest problems.

Unemployment continues to feature amongst the most important problems at both national (28\%) and local (26\%) levels. Other major problems at the local level concern basic infrastructure and services such as electricity (28\%), roads (24\%), water $(22 \%)$ and lack of health care/clinics/hospitals $(17 \%)$, as in previous years.

Over half of respondents (54\%) say they fear for their personal safety in their local area. However, much higher proportions of respondents report at least sometimes fearing for their safety in the West (66\%), North East (64\%) and South East (61\%), than in other parts of the country. There has also been a significant rise in the incidence of crime and violence experienced by respondents in the South East and the North East since 2009. 
Seventeen percent of respondents report that they or someone in their family have been victims of violence or crime in the past year. The most common form of crime experienced remains physical attack or beating (35\%) followed by racketeering and extortion (12\%) and various forms of theft (10\%-12\%). Nearly one in ten victims of violence report that this was due to the actions of militias and insurgents $(9 \%)$ and about one in sixteen report that it was due to the actions of foreign forces $(6 \%)$. Violence resulting from militant/insurgent actions is mentioned most often in the Central/Hazarajat (21\%), Central/Kabul (15\%), North East (12\%), North West (9\%), South West (9\%), West (9\%) and East (8\%). Violence due to the actions of foreign forces is most commonly reported in the East (19\%) and South West (11\%).

Levels of fear to participate in public activities continue to rise over time. Half of respondents $(51 \%)$ say they would have no fear participating in resolving problems in the community, but this is the only activity in which a majority of people say they can participate without fear. The proportion of respondents who express fear to vote in a national election has risen significantly, from 51\% in 2009 to $60 \%$ in 2010. This is now true for the majority of respondents in the South West (83\%), South East (78\%), East (69\%), West (64\%) and North East (62\%) of the country.

Support for the Government's approach for negotiation and reintegration of armed opposition groups is significantly higher in 2010 than in 2009. Eighty three percent of respondents support the government's attempts to address the security situation through negotiation and reconciliation with armed anti-government elements, compared to $71 \%$ in 2009. Support is highest in the East (89\%), South East (85\%) and North West (85\%) and lowest in the Central/Hazarajat region (78\%). Eighty-one percent agree with the government providing assistance, jobs and housing to those who lay down arms and want to reintegrate into society, compared to $71 \%$ in 2009 . Men (88\%) are more supportive than women (78\%) of this approach. Around three quarters of all respondents $(73 \%)$ think that the government's reconciliation efforts will help stabilize the country.

The proportion of respondents who say they have some level of sympathy with the motivations of armed opposition groups has fallen from 56\% in 2009 to $40 \%$ in 2010. However, at least half of respondents say they have some level of sympathy with armed opposition groups in the South West (52\%), South East (50\%) and West $(50 \%)$.

In 2010, Afghans give a more optimistic assessment of their economic situation than in 2009. More Afghans say they are better off now than a year ago in all domains, particularly in terms of the financial wellbeing of their household (from 31\% in 
2009 to $42 \%$ in 2010), availability of products in the market (from 19\% in 2009 to $27 \%$ in 2010), quality of food diet (from 23\% in 2009 to $33 \%$ in 2010 ) and employment opportunities (from 11\% in 2009 to $17 \%$ in 2010).

In terms of local amenities and services, respondents continue to report the greatest satisfaction with the availability of education for children (68\%), water for drinking $(63 \%)$ and the ability to move safely in local areas (63\%). Just under half of respondents are satisfied with services related to water for irrigation $(49 \%)$ and clinics and hospitals (46\%). Respondents are least satisfied with the availability of jobs and electricity. Seventy two percent say the availability of jobs in their local area is bad and $66 \%$ say the same about the supply of electricity.

More than half (54\%) of respondents say they are aware of development projects in their local area relating to education and to the reconstruction/building of roads and bridges. Forty-three percent are aware of projects related to drinking water supply, 39\% know of healthcare programs and 28\% are aware of programs relating the electricity supply. Varying levels of awareness of development projects across regions suggests that there is a heavier concentration of donor assisted development projects in certain areas of the country, particularly the East, while other regions, especially the Central/Hazarajat and to a lesser extent the North West, are less aware of development assistance.

Satisfaction with the performance of the national government has risen steadily over the last three years (from 67\% in 2008 to $71 \%$ in 2009 and $73 \%$ in 2010). The 2010 survey records the highest levels of positive assessments of national government performance since 2007 in almost all regions. Satisfaction with the performance of central government in policy and service delivery is consistently highest in the East, North West, and Central/Kabul regions. The most commonly mentioned achievements of the current government are a better education system $(27 \%)$, reconstruction $(24 \%)$ and establishing peace and security $(24 \%)$. The most commonly mentioned government failings are administrative corruption (37\%), insecurity (30\%), lack of job opportunities (17\%) and weak government $(10 \%)$.

In terms of local government, respondents give the most positive assessment of the performance of Provincial Councils (78\%), followed by district authorities (61\%) and municipalities (53\%). However, in 2010 the level of satisfaction with the performance of provincial government rose slightly (from 75\% in 2009 to $78 \%$ ) but fell for district authorities (from 69\% in 2009 to 61\%) and municipal authorities (from $58 \%$ in 2009 to $53 \%$ ). 
The majority of respondents say that corruption is a major problem in all facets of life and at all levels of government. Fifty-five percent say corruption is a major problem in their daily lives, $50 \%$ say this about their neighborhood, $56 \%$ say corruption is a major problem in local authorities, $65 \%$ say this about their provincial government and $76 \%$ say corruption is a major problem for the country as a whole. Around half of respondents who had contact with basic public services such as accessing healthcare, applying for jobs, receiving official documents and dealing with the police or the courts encountered some level of corruption.

Confidence in representative bodies remains relatively high. Representative bodies continue to enjoy the confidence of around two thirds of respondents, including community shura and jirga (66\%), Provincial Councils (62\%), Community Development Councils (CDC) (61\%) and Parliament (59\%). Sixty-seven percent of respondents say parliament is useful (including $28 \%$ who say it is very useful). Sixty four percent say that they are satisfied with their MP representing them in the Parliament.

Nationally $25 \%$ of respondents say that people feel safer to express their opinions now than a year ago while $17 \%$ say that people feel less safe to do so now, especially in the South West (27\%), South East (21\%) and Central/Kabul (20\%) regions. The major barriers to freedom of expression are identified as fear for personal safety (34\%), poor local security conditions (25\%), presence of the Taliban $(24 \%)$ and government restrictions on freedom of political opinion $(11 \%)$

Eighty-one percent of respondents say they agree with the democratic principle of equal rights for all groups to participation and representation. This figure has remained stable since 2009 , but does not reverse the declining trend which has been evident since 2007 (from 90\% in 2006 and 2007 to 84\% in 2008, 80\% in 2009 and $81 \%$ in 2010). However, levels of support for allowing peaceful opposition rose significantly in 2010 to $83 \%$ after falling consistently from $84 \%$ in 2006 to $81 \%$ in 2007,78 in 2008 and $77 \%$ in 2009.

Perceptions of elections remain positive in 2010. Around three quarters (74\%) of respondents say they think elections have improved the country. However, 2010 sees a significant decline in public confidence in a number of election-related institutions including the Independent Election Commission (from 67\% in 2009 to 54\% in 2010) and political parties (from 47\% in 2009 to $43 \%$ in 2010).

The majority of respondents (54\%) say that the 2009 Presidential elections were free and fair. However this is lower than the 64\% of respondents who in 2009 had said they expected the Presidential elections would be free and fair before the poll was held. Perceptions that the 2009 Presidential elections were not free and fair were highest in the South East (47\%), South West (44\%), Central/Hazarajat (29\%), North 
West $(27 \%)$ and East (27\%) regions. Respondents who thought the 2009 elections were not free and fair identified a range of problems such as cheating in the vote count $(40 \%)$ and buying of votes $(33 \%)$. A small proportion mentioned that men voted in the place of women $(7 \%)$.

The survey was conducted in June 2010 with the Parliamentary elections scheduled for September. Three months before the elections $78 \%$ of respondents were aware of the elections. Awareness of the upcoming parliamentary elections in 2010 was lower than the level of awareness for the same period regarding the planned presidential elections in 2009 (85\%), and significantly lower than the first presidential election in 2004 (91\%). Around three quarters $(74 \%)$ of respondents said they were likely to vote in upcoming parliamentary elections, including 39\% who said this was very likely. These figures are similar to those regarding participation in the presidential and Provincial Council elections in 2009, although in 2009 almost half of respondents (48\%) said they were very likely to vote. It would seem however that voting intention reported by survey respondents in 2010 was significantly higher than actual electoral participation which has been estimated at around $40 \%$ nationally for the 2010 parliamentary poll.

As in previous years, education and illiteracy (31\%) remain the major problems facing women in Afghanistan. Stated support for gender equality remains high, including support for equal educational opportunities for women (87\%). However, support for women being allowed to work outside the home continues to fall, from $71 \%$ in 2006 to $64 \%$ in 2010 , which is the lowest level recorded to date.

Radio remains the most accessible media for Afghan households. Eighty-two percent of respondents say they own a functioning radio and there is little difference in radio ownership between urban and rural areas. Other communications technologies such as television, mobile phones and computers are significantly more accessible in urban areas. Just under half $(46 \%)$ of respondents use radio most often to get news and information, while just over a quarter (28\%) use television. Around one in five respondents $(19 \%)$ depend on friends and family to receive news and information. Low income households continue to have the lowest levels of access to radio (68\%) and television (69\%).

2010 saw an increase in mobile telephone ownership compared to previous years. Since 2009 the majority of respondents (59\%) now have access to this technology.

\subsection{Summary}

In 2010, the proportion of respondents who say the country is moving in the right direction has risen, and those who say it is moving in the wrong direction has fallen compared to 2008 and 2009. 
Security continues to be a major factor in the way respondents assess the direction of the country. Good security is identified as the most important reason for optimism, although it is mentioned by fewer respondents this year than in 2009. However, insecurity is also cited as the main reason for pessimism, and by slightly more respondents in 2010 than in 2009.

Insecurity (including attacks, violence and terrorism) is also identified as the biggest problem in Afghanistan, particularly by respondents in the South East, South West and West of the country. Moreover, security conditions imposed greater restrictions on the movement of survey researchers in 2010 in all regions except the Central/ Hazarajat, indicating that insecurity now affects increasing parts of the country. Given the limited access of survey researchers to insecure areas, assessments of the security situation in the 2010 survey should be interpreted with some caution.

Levels of fear for personal safety and to participate in various public activities continue to rise. However, the reasons for this appear to differ across regions. While fears for safety in the Southern regions and the West of the country appear to be correlated with poor local security conditions, levels of fear in the North East and South East appear consistent with a significant rise in the incidence of crime and violence experienced by respondents.

In 2010, the only activity in which a majority of people say they can participate without fear is resolving problems in their community. The proportion of respondents who express fear to vote in a national election has risen significantly since 2009 , when the elections were accompanied by reports of intimidation of voters by antigovernment militants, and accusations of widespread electoral malpractice. In 2010 the majority of respondents in five of the eight regions say they would be afraid to vote in national elections, and similar trends are visible for other public activities such as running for public office and participating in a peaceful demonstration.

Actual experience of crime and violence remains relatively low, although there has been a significant rise in reported criminal victimization amongst respondents in the North East and South East. Victims most often report crime to the Afghan National Police (ANP), particularly in urban areas where access to the police is likely to be easier. However, crime is also reported to a wide range of other governmental and social institutions including district governor/woleswal, the Afghan National Army (ANA), shura/elders, tribal leaders/maliks and mullahs. The ANA and the ANP remain the public institutions which enjoy the highest levels of public confidence and the majority of respondents think these bodies are effective in performing their functions, although they also believe that both the ANA and the ANP are unprofes- 
sional and poorly trained and require the support of foreign troops. There has also been a significant fall in the last year in the proportion of respondents who agree that the ANP helps to improve security.

Support for the government's approach to negotiation and reintegration of armed opposition groups is significantly higher in 2010 than in 2009, suggesting that an increasing proportion of the Afghan public is in favor of a political solution to the ongoing conflict in the country, rather than a purely military one. The highest levels of support for the reintegration approach are in the East and West, which are also amongst the regions that record the highest levels of sympathy for armed opposition groups. Women are less supportive of the government's reintegration efforts than men and are less likely to say that reintegration of armed opposition groups will stabilize the country. Hazara respondents record the highest proportion who say that reintegration will stabilize the country, but the lowest levels of support for government efforts to negotiate and reintegrate former militants, suggesting that the lower levels of support for the government's reintegration efforts in this region are not related to concerns about security and stability.

In 2010, Afghans give a more optimistic assessment of their economic situation than in 2009. More Afghans say they are better off now than a year ago in all domains, particularly in terms of the financial wellbeing of their household. However, the benefits of increased financial well-being are not evenly shared, with those in the highest income bracket significantly more likely to report an improvement in their financial well-being in the past year than those in the lowest income category. Employment appears to be a major factor affecting perceptions of economic wellbeing. In 2010 unemployment is again identified as one of the biggest problems at both national and local levels and the majority of respondents express dissatisfaction at government performance in reviving/developing the economy and the creation of job opportunities.

Alongside unemployment, other basic infrastructure and public services, such as electricity, roads, water and healthcare, continue to dominate the list of problems at the local level. Respondents remain least satisfied with the provision of electricity, which is identified as the most critical need in the East, West and North West. Roads emerge as the top priority in the Central/Kabul, South West and North East regions. The most critical need in the South East is water supply, particularly for irrigation, whereas in the Central/Hazarajat it is health care. Overall assessments of the availability of most basic facilities and public services have not registered significant improvement over time, and satisfaction with health services, such as the availability of clinics and hospitals and the availability of medicines, has been falling consistently since 2007. 
On the other hand, respondents are positive about the level of reconstruction and rebuilding, which remains the second most important reason for optimism cited by respondents who say the country is moving in the right direction. As in previous years, respondents are most satisfied with the availability of education for children in their local area, and the opening of schools for girls continues to be mentioned as a reason for optimism in the country, although to a lesser degree than in 2009.

The majority of respondents are also aware of development projects in their local area relating to education and the same is true for projects targeting the reconstruction or building of roads and bridges. However, levels of awareness of development projects across regions suggests that donor assisted development projects are heavily concentrated in certain areas of the country, particularly the East, while other regions, especially the Central/Hazarajat and to a lesser extent the North West, are significantly less aware of development assistance. This is likely to be due, in part, to donor strategies designed to link development initiatives with security related initiatives. Indeed, awareness of security-related projects such as de-mining and demilitarization/disarmament are also highest in the East and the North East.

In 2010, there has been a significant fall in confidence in both national and international non-governmental organizations (NGOs) compared to previous years. This lower confidence corresponds with the perception that both NGOs and the donors who fund them more often make decisions that serve their own interests rather than the interests of the Afghan public. This drop in confidence in 2010 may also be influenced by changes to the legal framework governing the operations of NGOs which may make their work less evident to the Afghan public.

Satisfaction with the performance of the national government has risen steadily over the last three years and 2010 records the highest levels of positive assessments of national government performance since 2007 in almost all regions. Satisfaction is highest in the North West, East and North East. These are also the regions that record the highest proportion of respondents who think the country is going in the right direction.

Government performance is judged most positively with regard to the provision of basic public services such as education, healthcare and security, but least positively with respect to developing the economy, creating jobs and fighting corruption. These findings are consistent with respondents' views of the availability of basic services and amenities in their local area, clearly suggesting that the public's assessment of government performance is closely related to the ability of government to provide basic public services at the local level. The greatest achievements of government identified by respondents are broadly similar to the reasons for optimism given 
by respondents who say that the country is moving in the right direction, and the same is true of the government's main failings which closely mirror the reasons for pessimism, suggesting that respondents consider government to play a critical role in leading the country towards positive development.

In terms of local government, respondents give the most positive assessment of the performance of Provincial Councils, followed by district authorities and municipalities. The highest levels of satisfaction with provincial government are recorded in the North West and Central/Kabul regions and the lowest in the South East and South West. Nationally, the overall level of satisfaction with the performance of municipal authorities decreased in 2010 compared to 2009, particularly in the North West, North East, South West and Central/Hazarajat. On the other hand, satisfaction with municipal authorities increased in the East, West and South East. Positive assessments of the performance of rural local authorities decreased in almost all regions in 2010 compared to 2009, except in the Central/Hazarajat.

The majority of Afghans continue to say that corruption is a major problem in all facets of life and at all levels of government. In 2010, there has been a sharp increase since 2009 in the proportion of respondents who identify corruption as one of Afghanistan's major problems, and as a main reason for pessimism amongst respondents who say that the country is moving in the wrong direction. Corruption is also given greater emphasis than insecurity as a government failure, suggesting that respondents feel the government is better placed to tackle this issue but has failed to do so. This is borne out by respondents' experience that between a third and a half of contacts with core government institutions involve some level of corruption

Confidence in both formal and informal representative bodies, including community shura and jirga, Provincial Councils, Community Development Councils (CDC) and Parliament remains relatively high. More respondents believe that the government considers the Afghan public interest rather than its own interests when making decisions, however this is not the case for other public institutions such as the courts or Parliament. Nonetheless, the majority of respondents are satisfied with their MP representing them in the Parliament, particularly in the North West, East, North East, West and Central/Hazarajat. With the exception of the Central/Hazarajat, these regions also record the highest levels of confidence in the ability to influence government decisions and the highest levels of satisfaction with the performance of central government and government service provision, suggesting that perceptions of the performance of individual MPs and perceptions of the performance of government generally are closely associated. Conversely, the South West and South East regions record corresponding low levels of confidence and satisfaction across all these domains. 
Support for the application of democratic principles of governance remains high. There has been little change in the quality of freedom of expression in the last year, with slightly more respondents saying that it is now safer to express their political opinions, than those saying it has become less safe. However, a higher proportion of Pashtun respondents report that it is less safe now to express their opinions compared to one year ago than those from any other ethnic group. Greater limitations to freedom of expression are particularly mentioned in the South West, South East and Central/Kabul regions. The Southern regions are also those that most frequently identify security as a significant local problem. Responses show that local security conditions and the guarantee of freedom of expression are the key factors in making people feel safer to express their opinions.

Levels of agreement with the democratic principle of equal rights for all groups to participation and representation remain high, but do not reverse the declining trend which has been evident since 2006. However, levels of support for allowing peaceful opposition rose significantly in 2010 after falling consistently since 2006. In 2010 the majority of respondents agree that a person should vote the way his or her community votes, not how they feel individually, although this figure has been falling since 2008. Only in the North East do the majority of respondents say that voting should be a matter of individual choice.

When the survey was conducted in June 2010, with the Parliamentary elections scheduled for September, over three quarters of respondents were aware of the planned polls and a similar proportion intended to vote. Levels of awareness were lower than for the presidential elections in 2009 although voting intention was about the same. It would seem however that voting intention reported by survey respondents was significantly higher than actual electoral participation which has been estimated at around 40\% nationally for the 2010 parliamentary poll.

The overall perceptions of elections remain positive in 2010 with around three quarters of respondents saying that elections have improved the country. However, 2010 sees a significant decline in public confidence in a number of election-related institutions. Confidence in the Independent Election Commission declined significantly compared to 2009. This decrease may be due to the contested performance of the IEC in the 2009 elections, which were marred by widespread irregularities and accusations of bias leveled at the Commission. Confidence in political parties also peaked in the run up to the 2009 elections, but fell back in 2010 to a level similar to those recorded in previous years.

Perceptions of the 2009 presidential elections have clearly had an impact on public confidence and the willingness of respondents to participate in electoral processes. While a slim majority of respondents say that the 2009 Presidential elections were 
free and fair, the figure is significantly lower than those who had said they expected the Presidential elections would be free and fair before the poll was held. Problems identified with the 2009 elections include cheating in the vote count, buying of votes, restrictions to women's electoral participation, including men voting on behalf of women, and husbands not letting their wives vote, and intimidation of voters or party activists. Analysis of responses reveals that respondents who said that they intended to vote in the 2010 elections are predominantly those who think that the 2009 elections were free and fair, and who believe that elections have improved the country, suggesting that public confidence in the quality of the electoral process has a significant positive impact on people's willingness to exercise their right to democratic participation.

The majority of respondents were confident that the Afghan government could conduct elections on its own in 2010, however the majority in all regions, except the South West and South East also feel that the international community should continue to play a role.

As in previous years, education and illiteracy remain the major problems facing women in Afghanistan. The second biggest problem identified is the lack of job opportunities for women, particularly in the North West and North East followed by the Central/Hazarajat, Central/Kabul and Western regions. These are also the regions that identify unemployment as a major problem either at national or local level, suggesting that concern about job opportunities for women is often part of an overall concern about employment, rather than a specific issue for women. However, the Central/Kabul, Central/Hazarajat, North West and North East are also the regions where the largest number of respondents say that women should be allowed to work outside the home, suggesting that there is greater demand and opportunity for women to take jobs in these regions.

Stated support for gender equality remains high, including support for equal educational opportunities for women. However, support for women being allowed to work outside the home continues to fall to its lowest level to date in 2010. Support for women working outside the home is highest amongst women themselves, respondents in younger age groups and in low income households, which is likely to reflect the greater acknowledgement amongst low income families of the potential value of women's paid employment to increase household income.

Women continue to have a greater belief than men in equal sharing of political leadership roles, although there is little difference between the sexes regarding their opposition to being represented by a woman across a range of representative institutions. Opposition to being represented by a woman is lower for institutions close to the community level, such as shura/jirga, Community Development Councils (CDC) and Dis- 
trict Development Assemblies (DDA), but higher with regard to female representation in higher level institutions such as Provincial Councils and the national parliament.

Radio remains the most accessible media for Afghan households, although television ownership and the use of television to access news and information is increasing, particularly in urban areas. Low income households continue to have the lowest levels of access to radio and television, highlighting the challenges of providing information through technological means to the poorer segments of Afghan society. Since 2009 the majority of respondents own a mobile telephone and the proportion continues to rise. Computer ownership has also almost doubled between 2008 and 2010 although the proportion of respondents who own one remains very small compared to other forms of communication technology. Only in the Central/Kabul region do most respondents get news and information from television rather than radio, whereas in the Central/Hazarajat, where access to both television and radio is comparatively low, friends and family still constitute a major source of information on news and current events.

The use of oral communication to get news and information is high, with more than half of respondents using meetings in the community and sermons in mosques for this purpose, showing that traditional means of information dissemination continue to remain important in Afghan society. Respondents continue to prefer to get information on local news and events from personal acquaintances rather than leadership figures within their community, however the proportion of respondents who rely on personal contacts to access information on local events has been falling since 2006. On the other hand, the popularity of both local and international radio stations as a source of local information has significantly increased, doubling between 2008 and 2010 .

\subsection{Restriction on survey field work and replacement of sampling points for security reasons}

In 2010 there were much greater restrictions on the movement of survey researchers due to security concerns compared to previous years. This limitation and restriction caused the survey field work administration to replace sampling points from those insecure areas to more secure areas. In 2010, more than one in six (16\%) random sampling points had to be changed across the country for security reasons. This is higher than 2009 when $12 \%$ of sampling points were changed for security reasons, and very much higher than in 2008 (3\%) and 2007 (2\%) when the replacement rate was not statistically significant. 
Replacements of sampling points due to security problems (Appendix 2: Methodology) COMPARISON OF 2007, 2008, 2009 and 2010

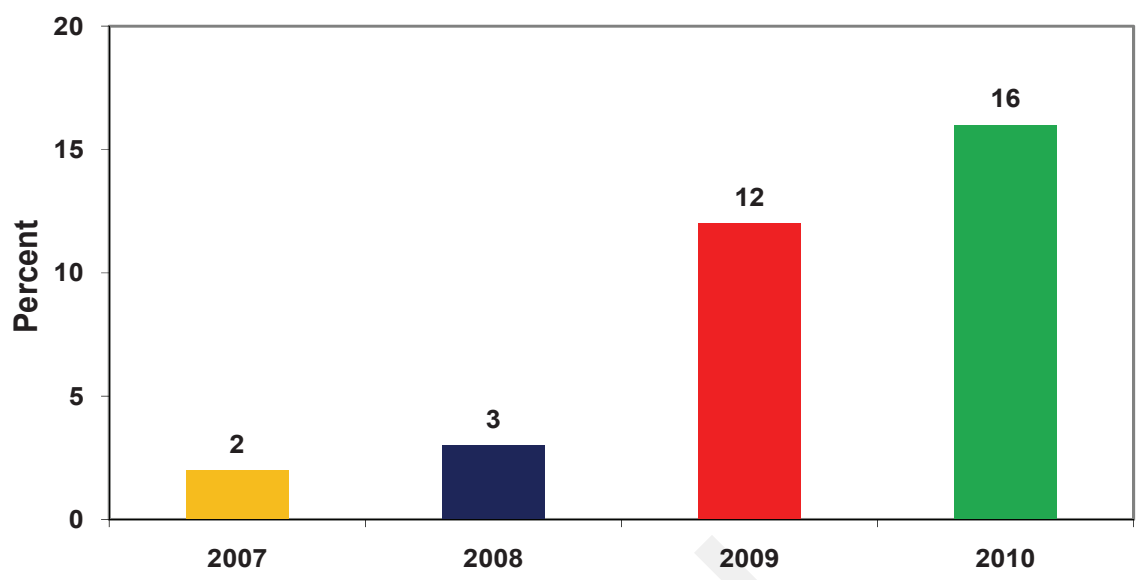

Fig. 1.1

This means that again in 2010 findings related to security and other issues in which the security dimension is an important factor are likely to under-represent the level of insecurity, given that survey researchers are unable to access insecure areas in increasingly large parts of the country.

The replacement of sampling points for security reasons since 2007 demonstrates clearly that the number of regions affected by security problems has been increasing. In 2007 , only 11 of the 626 sampling points had to be replaced because the areas were inaccessible due to security problems ( $2 \%$ of all sampling points). More than half of the replacements were made in just one region - the South East (55\% - 6 sampling points), and more than a quarter in a second region - the South West $(27 \%$ - 3 sampling points). One security-related replacement was needed in the West and another in the Central/Kabul region. No changes of sampling points were needed due to security problems in any of the other regions.

In 2008, 18 of the 659 sampling points were replaced due to security problems (i.e. $3 \%$ of all sampling points). These replacements were again mainly concentrated in the South East (6 replacements, 33\%) and South West (5 replacements, 28\%) but other replacements were distributed among seven of the eight regions with the exception of the North West. Two sampling points had to be replaced in the East and West and one each in the North East Central/Hazarajat and Central/Kabul regions.

However, in 2009 the total number of security-related replacements of survey sampling points increased fourfold, from $3 \%$ in 2008 to $12 \%$. One hundred and two 
of the 823 random sampling points were inaccessible to survey researchers due to insecurity, and replacements were required in all regions. In addition, the number of insecure areas which could not be accessed at least tripled in the South East (from 6 to 18) and the South West (from 5 to 17) and rose even more dramatically in all other regions, from 2 to 14 in the East and the West, from 1 to 13 in the Central/ Kabul region, from 1 to 11 in the North East. In the North West where no replacements had been needed in 2008, in 200913 sampling points had become inaccessible due to insecurity. In the Central/Hazarajat two replacements were needed in 2009, compared to just one in previous year.

In 2010, the situation continues to deteriorate. One hundred and thirty eight of the 885 random sampling points were inaccessible to survey researchers due to security problems ( $16 \%$ of all sampling points). Again the number of replacements rose significantly in most regions. The regions most affected continue to be the South East (28 replacements, compared to 18 in 2009), South West (24 replacements compared to 17 in 2009) and the East (21 replacements compared to 14 the previous year). In 2010 the situation in the North continues to mirror that of the South and East. In the North East 23 replacements were made, compared to 11 in 2009, and in the North West 20 sampling points were inaccessible, compared to 13 the previous year. There was a small drop in the number of security related replacements in the West (from 14 to 12) and the Central/Kabul regions (from 13 to 10). However, restricted accessibility for survey researchers show that insecurity continues to be widespread and appears to be increasing. In 2010 the Central/Hazarajat was the only region where no replacements of sampling points were made due to security problems.

Actual number of replacements of sampling points due to security problems (See Appendix 2: Methodology) ALL AND BY REGION COMPARISON OF 2007, 2008, 2009 AND 2010

\begin{tabular}{|l|c|c|c|c|c|c|c|c|c|}
\hline $\begin{array}{l}\text { Number of Sample } \\
\text { Points Replaced for } \\
\text { Security Reasons }\end{array}$ & All & $\begin{array}{c}\text { Central/ } \\
\text { Kabul } \\
\mathbf{( \% )}\end{array}$ & $\begin{array}{c}\text { East } \\
\mathbf{( \% )}\end{array}$ & $\begin{array}{c}\text { South } \\
\text { East } \\
\mathbf{( \% )}\end{array}$ & $\begin{array}{c}\text { South } \\
\text { West } \\
\mathbf{( \% )}\end{array}$ & $\begin{array}{c}\text { West } \\
\mathbf{( \% )}\end{array}$ & $\begin{array}{c}\text { North } \\
\text { East } \\
\mathbf{( \% )}\end{array}$ & $\begin{array}{c}\text { Central/ } \\
\text { Hazarajat } \\
(\mathbf{\%})\end{array}$ & $\begin{array}{c}\text { North } \\
\text { West } \\
\mathbf{( \% )}\end{array}$ \\
\hline 2007 & 11 & 1 & 0 & 6 & 3 & 1 & 0 & 0 & 0 \\
\hline 2008 & 18 & 1 & 2 & 6 & 5 & 2 & 1 & 1 & 0 \\
\hline 2009 & 102 & 13 & 14 & 18 & 17 & 14 & 11 & 2 & 13 \\
\hline 2010 & 138 & 10 & 21 & 28 & 24 & 12 & 23 & 0 & 20 \\
\hline
\end{tabular}




\section{National Mood}

\subsection{Direction of the country}

The survey sought to uncover how the men and women of Afghanistan assess the overall situation of their country. Respondents were first asked whether they think things in the country today are going in the right direction or the wrong direction. Slightly less than half of the respondents $(47 \%)$ say that things in the country are moving in the right direction. However, a sizeable proportion $(27 \%)$ say things are moving in the wrong direction. About one in five respondents $(22 \%)$ has mixed views on the overall direction of the country.

Generally speaking, do you think things in Afghanistan today are going in the right direction, or do you think they are going in the wrong direction? (Q-4, base-6467)

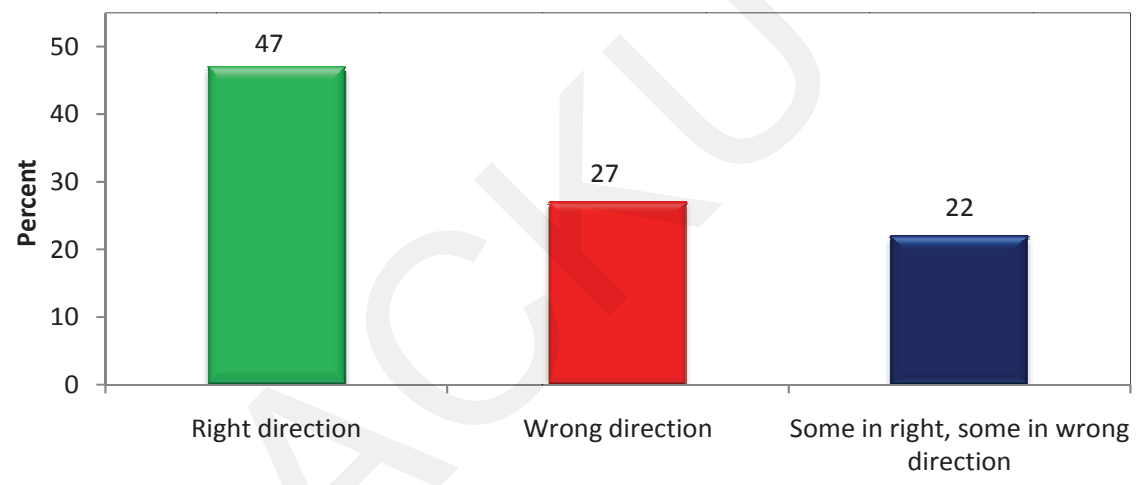

Fig 2.1

The assessment of the overall situation differs between ethnic communities. A higher proportion of Uzbeks $(64 \%)$ think that things are moving in the right direction than Tajiks (50\%), Hazara (49\%) and Pashtuns (41\%). On the other hand, one in three Pashtuns (33\%) think that things are moving in the wrong direction, but this is true only for one in five Hazara (21\%) and around one in seven Uzbek (15\%) respondents.

Income also seems to have a bearing on this issue: A higher proportion of households $(58 \%)$ with lower incomes think the country is moving in the right direction compared to higher income groups $(42 \%)$. About a third $(31 \%)$ of those in the high income categories say that the country is moving in the wrong direction compared to around a fifth $(19 \%)$ in the lowest group who hold this opinion. 
A clear majority in the North East (57\%) and North West (57\%), Central/Hazarajat $(52 \%)$ and the East (50\%) think that the country is moving in the right direction, while this is true for only around a third in the South West (31\%) and South East (37\%) regions. The North East, North West and Central/Hazarajat are the most likely to cite improving security as the main reason for optimism (see below 2.2 Reasons for optimism), whereas the Southern regions, along with the East are the most likely to mention insecurity as a reason for pessimism (see below 2.3 Reasons for pessimism). Three of the four regions where a majority of respondents say the country is moving in the right direction also report the highest levels of satisfaction with government provision of security services (the North East, North West and Central Hazarajat). The East and North West also record amongst the highest levels of satisfaction with the provision of other government services, but satisfaction with other services is low in the North East and Central/Hazarajat (see Chapter 7, 7.3 Satisfaction with central government performance in policy and service delivery). This again suggests that security issues continue to play a major role in respondents' overall perceptions about the situation in the country and the prospects for the future.

The proportion of respondents saying that the country is moving in the right direction in $2010(47 \%)$ is the highest since 2006. In 2010, $27 \%$ say that the country is moving in the wrong direction compared to $29 \%$ in 2009 and $32 \%$ in 2008 who felt so. This figure is higher than in 2007 (24\%) and 2006 (21\%). However, given the importance of security issues for perceptions of the direction of the country, and the increasing limitations on the movement of survey researchers due to security concerns in the last two years, this level of optimism should be read with some caution (see Chapter 1, 1.3 Restriction on survey field work and replacement of sampling points for security reasons). The proportion of respondents with mixed views has been stable at around one fifth for the last three years.

Generally speaking, do you think things in Afghanistan today are going in the right direction, or do you think they are going in the wrong direction? (Q-4) COMPARISON BETWEEN 2006, 2007, 2008, 2009 AND 2010

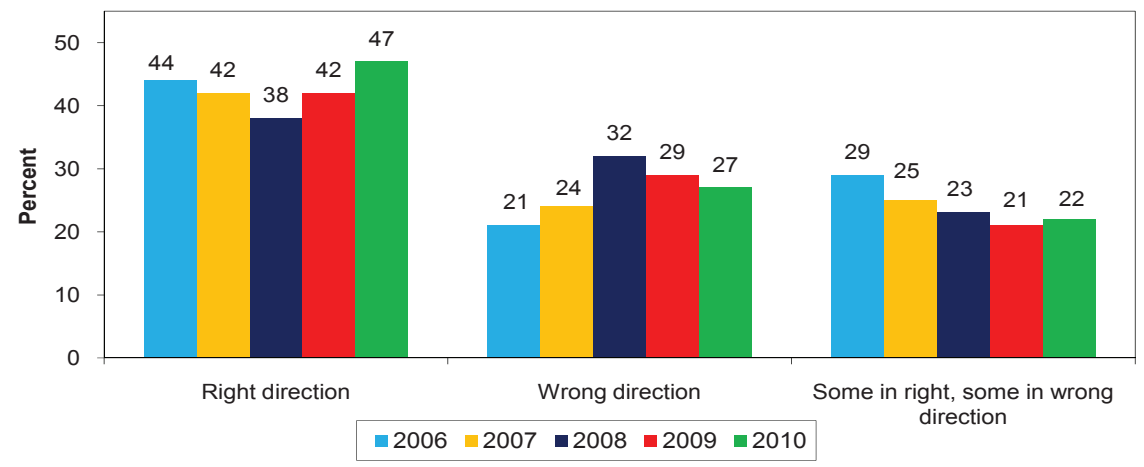

Fig 2.2 


\subsection{Reasons for optimism}

Respondents who say that the country is moving in the right direction (47\% of all respondents) were then asked to give the two most important reasons why they think this is so. The most commonly mentioned reasons are good security (38\%), reconstruction/rebuilding (35\%) and opening of schools for girls (15\%). One in eight respondents mention peace or end of war $(12 \%)$ while around one in ten mention economic revival (10\%), improvement in the education system $(10 \%)$ and good government $(9 \%)$ as factors for optimism.

Why do you say that things are moving in the right direction? (Q-5a\&b combined, Base 3020: Those saying right direction)

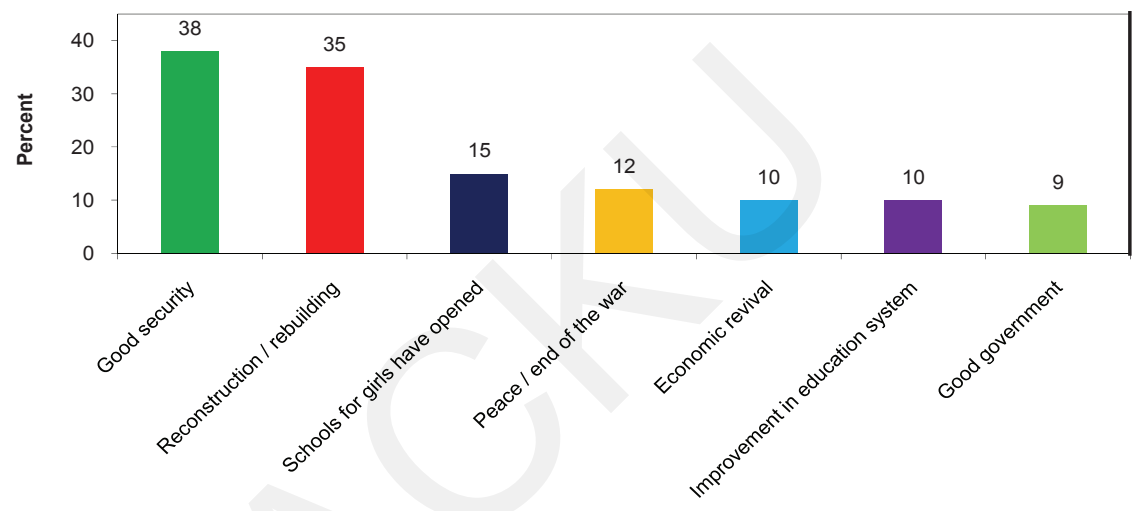

Fig 2.3

Even allowing for the limited access of survey researchers to insecure areas, the proportion of those identifying good security as the main reason why the country is moving in the right direction has dropped this year across all regions except for the Central/Hazarajat where 59\% give this reason in 2010 compared to $53 \%$ in 2009. Good security is also most frequently mentioned by Uzbeks (59\%), Hazara (43\%) and Tajiks (41\%) whose populations are largely concentrated in the North East, North West and Central/Hazarajat regions. On the other hand good security is only mentioned by $13 \%$ of respondents in the South East and $21 \%$ in the South West.

Reconstruction/rebuilding is most frequently cited as the main reason for the optimism in the Central/Kabul (42\%), South East (42\%) and South West (40\%) regions. Conversely, only $12 \%$ of respondents mention this in the Central/Hazarajat region. 
Peace and the end of war is cited by over one in four respondents (27\%) in the Central / Hazarajat region and nearly one in five (19\%) in the North West, but just $2 \%$ in the East and under one in ten in the West (7\%), South West $(8 \%)$ and South East $(8 \%)$.

The proportion of respondents citing the opening of schools for girls also shows significant regional variations with one in five citing this in the West (20\%), North East $(20 \%)$ and Central/Kabul (20\%) regions, but one in twenty-five giving this reason in the Central/Hazarajat (4\%), and fewer than one in ten in the North West $(7 \%)$ and South West (8\%).

Among households with lower incomes, good security is the main reason mentioned for the country moving in the right direction (52\%). For those in higher income group the main reason mentioned is reconstruction/rebuilding (43\%).

Table 2.1: Reasons given by those saying things are moving in the right direction (Q-5a\&b combined, Base 3020) BY REGION

\begin{tabular}{|c|c|c|c|c|c|c|c|c|c|}
\hline $\begin{array}{l}\text { Base: Those saying } \\
\text { right direction }\end{array}$ & $\begin{array}{l}\text { All } \\
(\%)\end{array}$ & $\begin{array}{c}\text { Central/ } \\
\text { Kabul } \\
(\%)\end{array}$ & $\begin{array}{l}\text { East } \\
(\%)\end{array}$ & $\begin{array}{c}\text { South } \\
\text { East } \\
(\%)\end{array}$ & \begin{tabular}{|c|} 
South \\
West \\
$(\%)$
\end{tabular} & \begin{tabular}{l|} 
West \\
$(\%)$
\end{tabular} & $\begin{array}{c}\text { North } \\
\text { East } \\
(\%)\end{array}$ & $\begin{array}{c}\text { Central/ } \\
\text { Hazarajat } \\
(\%)\end{array}$ & $\begin{array}{c}\text { North } \\
\text { West } \\
(\%)\end{array}$ \\
\hline Good security & 38 & 39 & 29 & 13 & 21 & 25 & 53 & 59 & 51 \\
\hline $\begin{array}{l}\text { Reconstruction / } \\
\text { rebuilding }\end{array}$ & 35 & 42 & 32 & 42 & 40 & 31 & 29 & 12 & 38 \\
\hline $\begin{array}{l}\text { Schools for girls } \\
\text { have opened }\end{array}$ & 15 & 20 & 11 & 13 & 8 & 20 & 20 & 4 & 7 \\
\hline $\begin{array}{l}\text { Peace / end of the } \\
\text { war }\end{array}$ & 12 & 12 & 2 & 8 & 8 & 7 & 12 & 27 & 19 \\
\hline Economic revival & 10 & 11 & 9 & 11 & 9 & 12 & 12 & 4 & 5 \\
\hline Good government & 9 & 7 & 11 & 7 & 10 & 14 & 5 & 16 & 10 \\
\hline $\begin{array}{l}\text { Democracy / } \\
\text { elections }\end{array}$ & 7 & 6 & 12 & 5 & 8 & 9 & 10 & 3 & 4 \\
\hline $\begin{array}{l}\text { Freedom / free } \\
\text { speech }\end{array}$ & 4 & 6 & 1 & 1 & 3 & 6 & 3 & 9 & 5 \\
\hline
\end{tabular}

Since 2006, good security and reconstruction/rebuilding have consistently been identified as the two most important reasons why respondents say that the country is moving in the right direction. The proportion of people mentioning good security rose steadily between 2006 (31\%) and 2009 (44\%), however, the proportion of people citing this reason dropped to $38 \%$ in 2010, close to the level recorded in 2008 $(39 \%)$. On the other hand, slightly more people mention peace/end of the war in $2010(12 \%)$ than in $2009(9 \%)$. 
The proportion mentioning reconstruction/rebuilding has been relatively consistent since 2007, with very little change between the figures recorded in 2009 (36\%) and 2010 (35\%). The opening of schools for girls is mentioned by fewer respondents this year $(15 \%)$ than in any year since 2006 . However, improvement in the education system generally is cited for the first time, by one in ten of respondents $(10 \%)$ as a reason for optimism.

Democracy and elections are also cited less frequently as reasons for optimism than in most previous years. They are mentioned by $7 \%$ of respondents in 2010 compared to $10 \%$ in 2009 shortly before the elections were held. The 2010 figure is as low as the one recorded in 2008 which, unlike 2010, was not an election year, suggesting that the 2009 elections have not substantially raised confidence in the electoral process as a reason for optimism about the future of the country (see Chapter 9, 9.10 Perceptions of the 2009 presidential elections). However, the figure for economic revival $(10 \%)$ is the highest since 2006 . There is a slight decrease in the perception of respondents who cite good government as a reason for optimism, from $12 \%$ in 2009 to $10 \%$ in 2010 , however this figure is consistent with those of previous years.

Table 2.2: Why do you say that things are moving in the right direction? (Q-5a\&b combined) COMPARISON BETWEEN 2006, 2007, 2008, 2009 AND 2010

\begin{tabular}{|l|c|c|c|c|c|} 
& $\begin{array}{c}\mathbf{2 0 0 6} \\
\mathbf{( \% )}\end{array}$ & $\begin{array}{c}\mathbf{2 0 0 7} \\
\mathbf{( \% )}\end{array}$ & $\begin{array}{c}\mathbf{2 0 0 8} \\
\mathbf{( \% )}\end{array}$ & $\begin{array}{c}\mathbf{2 0 0 9} \\
\mathbf{( \% )}\end{array}$ & $\begin{array}{c}\mathbf{2 0 1 0} \\
\mathbf{( \% )}\end{array}$ \\
\hline Good security & 31 & 34 & 39 & 44 & 38 \\
\hline Reconstruction/ rebuilding & 21 & 39 & 32 & 36 & 35 \\
\hline Schools for girls have opened & 16 & 19 & 19 & 21 & 15 \\
\hline Democracy/ elections & 10 & 9 & 7 & 1 & 7 \\
\hline Peace/ end of the war & 29 & 16 & 21 & 9 & 12 \\
\hline Economic revival & 7 & 9 & 5 & 6 & 10 \\
\hline Improvement in Education System & - & - & - & - & 10 \\
\hline Good Government & 9 & 9 & 9 & 12 & 10 \\
\hline
\end{tabular}

\subsection{Reasons for pessimism}

Respondents who say that things are moving in the wrong direction $27 \%$ of all respondents) were also asked to give the two main reasons for their view. Insecurity is cited by $44 \%$ of respondents, making it by far the most important reason for pessimism. This indicates that security remains a key concern for Afghans and a significant factor in the way they assess progress in the country. Just over one in four respondents $(27 \%)$ identify corruption as the reason for pessimism, followed by bad government (18\%) and unemployment $(16 \%)$. 
Why do you say that things are moving in the wrong direction? (Q-6a\&b combined, Base 1747: Those saying wrong direction)

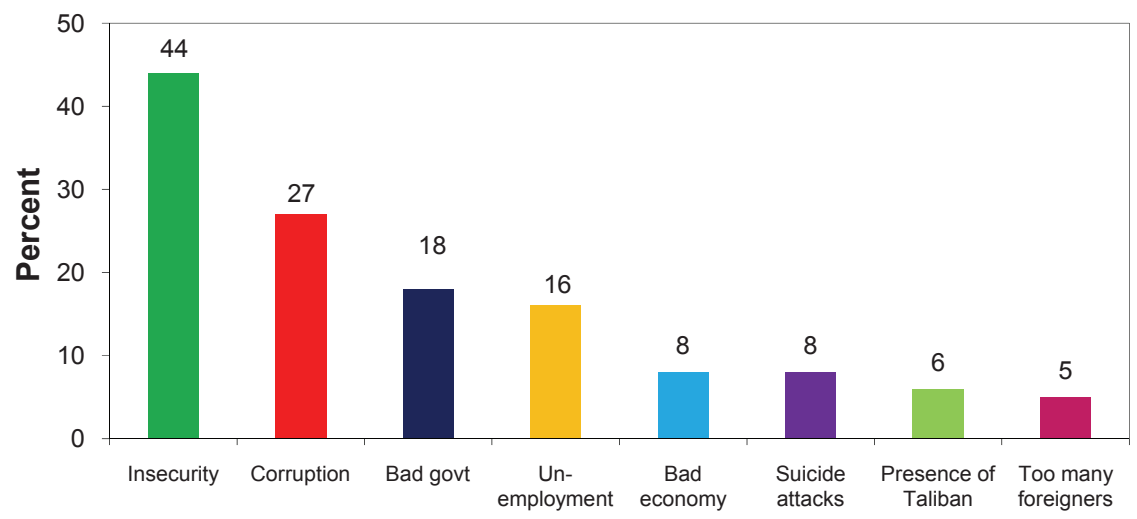

Fig 2.4

The reasons cited for believing that the country is moving in the wrong direction also differ significantly between regions. Whereas insecurity remains the most common reason given by respondents in all the regions, this is mentioned more frequently by residents of the South East (65\%), East (55\%) and South West (50\%). Similarly, though insecurity is cited by all ethnic groups, more Pashtuns $(52 \%)$, who represent the majority of the population in the South and East of the country, say this than Hazara (43\%), Uzbeks (41\%) and Tajiks (33\%).

Corruption is most often given as the reason the country is moving in the wrong direction in the North West $(34 \%)$ where it is mentioned as often as insecurity, followed by the West $(31 \%)$ and by more than a quarter of respondents in all other regions except the East $(22 \%)$ and the Central/Hazarajat $(10 \%)$.

Table 2.3: Why do you say that things are moving in the wrong direction? (Q-6a\&'b combined, base1747) BY REGION

\begin{tabular}{|c|c|c|c|c|c|c|c|c|c|}
\hline $\begin{array}{l}\text { Base: Those saying } \\
\text { wrong direction }\end{array}$ & $\begin{array}{l}\text { All } \\
(\%)\end{array}$ & $\begin{array}{c}\text { Central/ } \\
\text { Kabul } \\
(\%)\end{array}$ & $\begin{array}{l}\text { East } \\
(\%)\end{array}$ & $\begin{array}{l}\text { South } \\
\text { East } \\
(\%)\end{array}$ & \begin{tabular}{|c|} 
South \\
West \\
$(\%)$
\end{tabular} & $\begin{array}{l}\text { West } \\
(\%)\end{array}$ & $\begin{array}{c}\text { North } \\
\text { East } \\
(\%)\end{array}$ & $\begin{array}{c}\text { Central/ } \\
\text { Hazarajat } \\
(\%)\end{array}$ & $\begin{array}{c}\text { North } \\
\text { West } \\
(\%)\end{array}$ \\
\hline Insecurity & 44 & 35 & 55 & 65 & 50 & 39 & 33 & 42 & 34 \\
\hline Corruption & 27 & 27 & 22 & 26 & 26 & 31 & 29 & 10 & 34 \\
\hline Bad government & 18 & 18 & 8 & 11 & 18 & 24 & 24 & 29 & 24 \\
\hline Unemployment & 16 & 20 & 12 & 18 & 11 & 8 & 19 & 14 & 17 \\
\hline Bad Economy & 8 & 11 & 5 & 9 & 3 & 7 & 8 & 12 & 10 \\
\hline Suicide attacks & 8 & 8 & 20 & 8 & 5 & 3 & 7 & 0 & 4 \\
\hline Presence of Taliban & 6 & 6 & 11 & 5 & 5 & 4 & 6 & 5 & 6 \\
\hline $\begin{array}{l}\text { Too many foreigners } \\
\text { are getting involved }\end{array}$ & 5 & 4 & 4 & 2 & 6 & 6 & 7 & 12 & 2 \\
\hline
\end{tabular}


The proportion of respondents identifying insecurity as a reason for pessimism in 2010 (44\%) has risen slightly since 2009 (42\%), but remains lower than in 2007 (48\%) and 2008 (50\%). This shift may be due to the fact that in 2009 and 2010 many more areas were inaccessible to survey researchers for security reasons than in 2007 and 2008. On the other hand, the proportion of respondents mentioning corruption has significantly risen in 2010 (27\%) compared to 17\% in 2009, 19\% in 2008 and $13 \%$ in 2007. Fewer respondents mention bad government in general in 2010 (18\%) compared to 2009 (25\%). However, the figure is still higher than in $2006(15 \%)$ and $2007(12 \%)$. This may be due to the increased focus, particularly by the international community, on corruption as a key dimension of bad governance. The proportion of respondents mentioning a bad economy (8\%) and lack of reconstruction (4\%) are at their lowest levels since 2006. The proportion mentioning unemployment has remained stable since 2007 .

Why do you say that things are moving in the wrong direction? (Q-6a\&'b combined) COMPARISON BETWEEN 2006, 2007, 2008, 2009 AND 2010

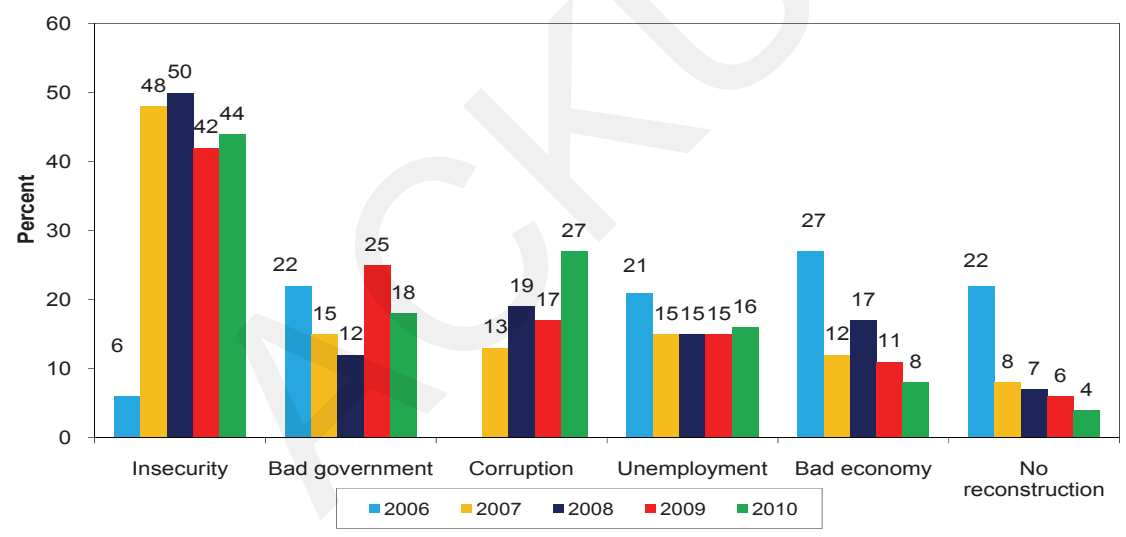

Fig 2.5

\subsection{Afghanistan's biggest problems: National level}

The survey attempted to gauge public opinion regarding the biggest problems facing Afghanistan as a whole. Insecurity (including attacks, violence and terrorism) is identified as the biggest problem in Afghanistan by over a third of respondents $(37 \%)$. This is followed by unemployment which is mentioned by $28 \%$ and corruption mentioned by $27 \%$ of respondents. Other major problems identified include poor economy (11\%), lack of education $(11 \%)$, poverty $(10 \%)$, presence of the Taliban $(8 \%)$ and interference of foreign countries. 
In your view, what is the biggest problem facing Afghanistan as a whole? (Q-7a\&b combined, Base 6467)

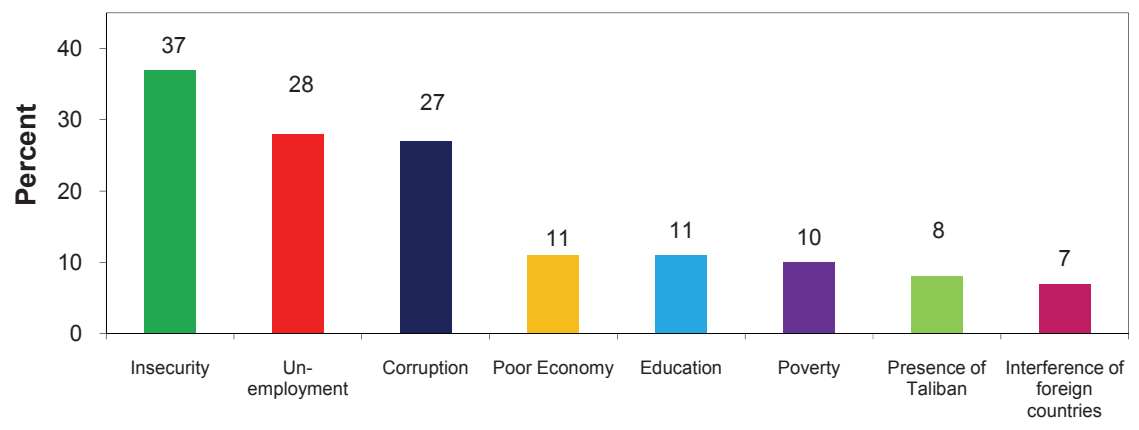

Fig. 2.6

Again, the regional variations are significant. Almost twice as many respondents in the South East (51\%) and a significantly larger proportion in the West (43\%) and South West $(42 \%)$ identify insecurity as the biggest problem facing the country than those living in the Central/Hazarajat region (28\%). Unemployment is most often identified as the most important issue facing the country by respondents living in the Central/Kabul (37\%), Central Hazarajat (31\%) and North West (30\%) regions. Though corruption is cited as the third biggest problem nation-wide, it is mentioned most often by respondents in the North East (35\%), East (33\%), South East (30\%) and North West (28\%).

Since 2006, insecurity and unemployment have consistently been identified as the biggest problems for the country as a whole. However, while the proportion of respondents identifying insecurity as the biggest problem in Afghanistan has remained almost the same since 2008. The proportion of respondents mentioning unemployment has gone down in 2010 (28\%) compared to previous years (35\% in 2009 and $31 \%$ in 2008). In contrast however, the proportion of respondents citing corruption has increased to $27 \%$ in 2010 , which is much higher than in previous years. (The figure was $17 \%$ in $2009,14 \%$ in 2008, $16 \%$ in 2007 and $19 \%$ in 2006). The proportion of respondents identifying education $(11 \%)$ and poverty $(10 \%)$ as major national problems remains broadly comparable with previous years. 
In your view, what is the biggest problem facing Afghanistan as a whole? (Q-7a\&b combined) COMPARISON BETWEEN 2006, 2007, 2008, 2009 AND 2010

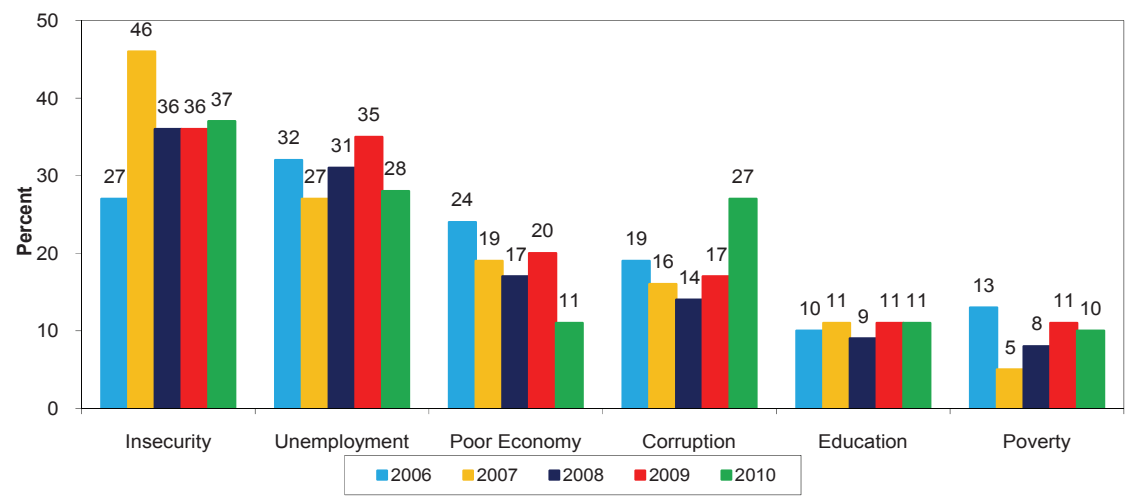

Fig 2.7

\subsection{Afghanistan's biggest problems: Local Ievel}

The biggest problems identified by respondents at the local level are quite different from those identified at the national level. The survey asked respondents about the biggest problem in their local area and invited them to mention two. As in previous years, it is development issues, rather than security or governance that priorities at the local level. The problems most often mentioned by respondents are electricity $(28 \%)$ and unemployment $(26 \%)$ followed by lack of roads $(24 \%)$, lack of drinking water $(22 \%)$, lack of health care/clinics/hospitals (17\%) and lack of education/ schools/literacy (16\%). Insecurity is also mentioned by $13 \%$ of respondents.

Unemployment is identified as one of the biggest problems at both national and local levels. Twenty-eight percent of respondents identify unemployment among the top two problems at the national level and a similar proportion (26\%) say the same at the local level.

What is the biggest problem in your local area? (Q-8a\&b combined, Base 6467)

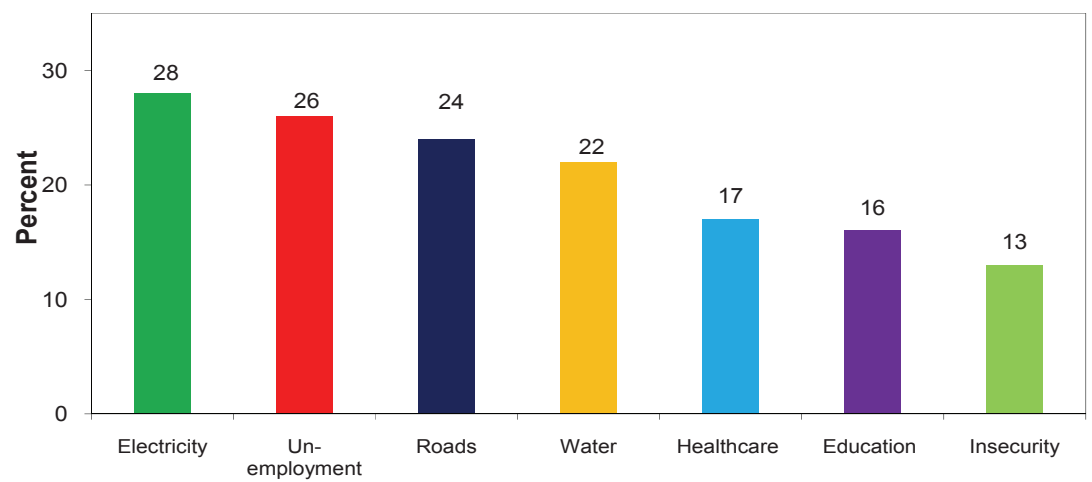

Fig. 2.8 
The local problem most often cited by respondents in urban areas is roads $(33 \%)$ followed by drinking water (23\%). In rural areas electricity $(29 \%)$ is identified as the biggest local problem followed by unemployment $(27 \%)$. More than twice as many respondents in rural $(15 \%)$ as urban $(6 \%)$ areas mention insecurity as a major local problem.

The identification of the biggest local problem varies by region. A lack of electricity features as the most important local problem in the East (42\%), North West $(40 \%)$ and North East (35\%). Lack of roads is cited as the most important problem in the Central/Kabul (30\%) region and is mentioned by more than a quarter of respondents in the North East (30\%), North West (29\%) and Central/Hazarajat (26\%) regions. Lack of drinking water is particularly mentioned in the North West $(37 \%)$.

Lack of access to healthcare is the biggest problem identified by respondents in the Central/Hazarajat (42\%) where it is mentioned by twice as many respondents as in any other region. Problems of education, schools and illiteracy are also mentioned most often in the Central/Hazarajat (26\%) and South West (27\%).

Unemployment is mentioned by the highest proportion of people in the South East (34\%), followed by the North East (27\%) and Central/Kabul (27\%) regions.

Although nationally only $13 \%$ of respondents mention insecurity as a significant local problem, more than one in four respondents in the South East $(29 \%)$ and South West $(26 \%)$ highlight insecurity in their local area, compared to less than one in twenty in the North West (5\%) and Central/Hazarajat (3\%).

Table 2.4: What is the biggest problem in your local area? (Q-8a\&b combined, Base 6467) BY REGION

\begin{tabular}{|c|c|c|c|c|c|c|c|c|}
\hline & $\begin{array}{c}\text { Central } \\
\text { /Kabul } \\
(\%)\end{array}$ & $\begin{array}{l}\text { East } \\
(\%)\end{array}$ & $\begin{array}{c}\text { South } \\
\text { East } \\
(\%)\end{array}$ & \begin{tabular}{|c|} 
South \\
West \\
$(\%)$
\end{tabular} & $\begin{array}{l}\text { West } \\
(\%)\end{array}$ & $\begin{array}{c}\text { North } \\
\text { East } \\
(\%)\end{array}$ & $\begin{array}{c}\text { Central/ } \\
\text { Hazarajat } \\
(\%)\end{array}$ & $\begin{array}{c}\text { North } \\
\text { West } \\
(\%)\end{array}$ \\
\hline Electricity & 16 & 42 & 21 & 23 & 30 & 35 & 15 & 40 \\
\hline Unemployment & 27 & 24 & 34 & 26 & 23 & 27 & 22 & 21 \\
\hline Roads & 30 & 19 & 14 & 11 & 22 & 30 & 26 & 29 \\
\hline Drinking Water & 16 & 16 & 17 & 11 & 24 & 26 & 25 & 37 \\
\hline Health care / clinics / hospitals & 19 & 15 & 14 & 11 & 13 & 21 & 42 & 18 \\
\hline Education / schools / literacy & 14 & 17 & 15 & 27 & 14 & 15 & 26 & 15 \\
\hline Insecurity / attacks / violence & 10 & 13 & 29 & 26 & 10 & 10 & 3 & 5 \\
\hline
\end{tabular}


The major local problems identified by the Afghan people have remained relatively stable since 2006. The identification of unemployment as a local problem was highest in 2006 (34\%) but has since remained stable at around 26\%. However, the identification of roads as a major local problem has risen steadily over this period from $14 \%$ in 2006 to $19 \%$ in $2007,18 \%$ in 2008, and $24 \%$ in 2009 and 2010 ).

What is the biggest problem in your local area? (Q-8a\&b combined) COMPARISON BETWEEN 2006, 2007, 2008, 2009 AND 2010

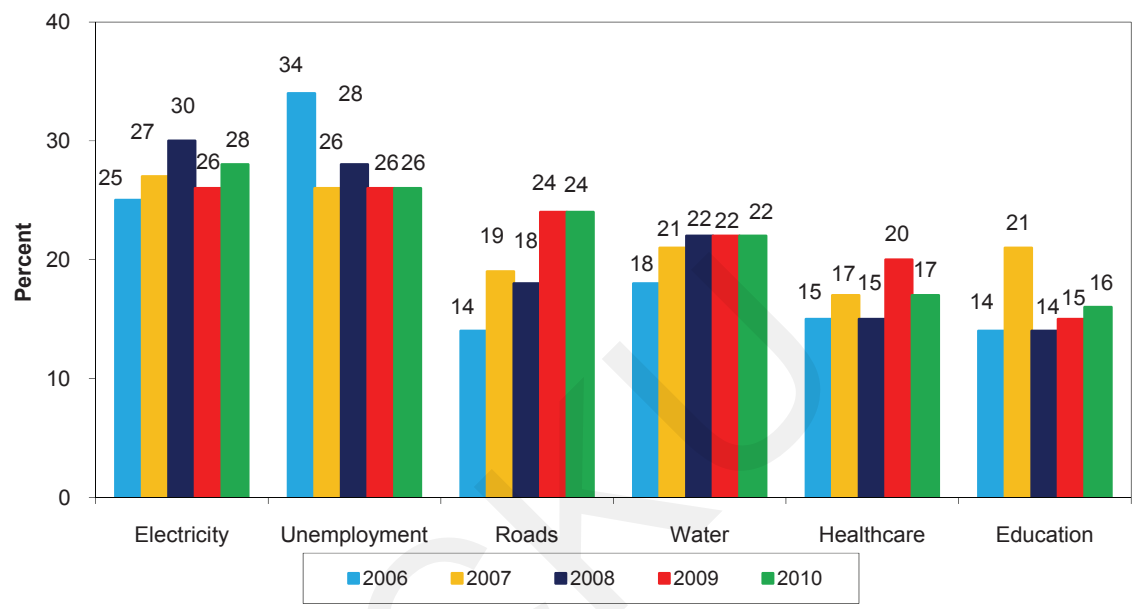

Fig 2.9 


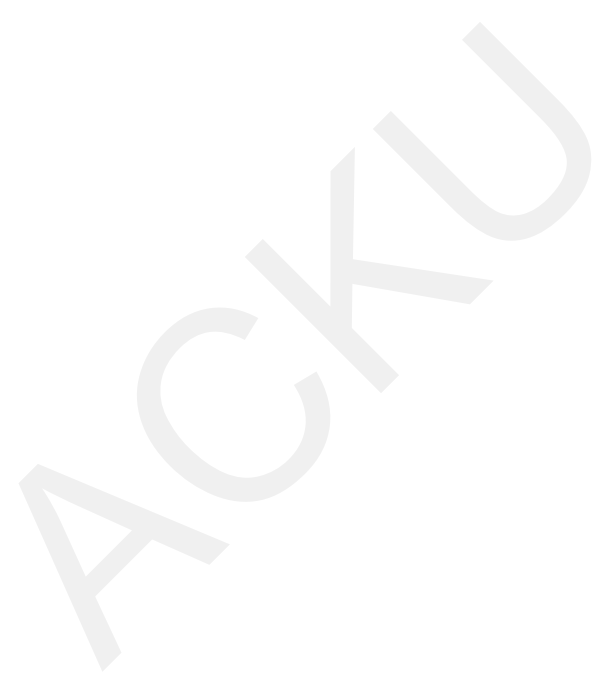




\section{Security}

\subsection{Fear for safety}

The survey attempted to measure perceptions of safety and security for individuals and their families. Slightly more than half $(54 \%)$ of respondents report that they often $(18 \%)$ or sometimes $(36 \%)$ fear for their personal safety or for that of their families. Another $20 \%$ say that they rarely fear for their safety while $26 \%$ say that they never do so. The proportion of respondents who say that they often fear for their safety has been rising steadily over the last five years (from 9\% in 2006 to $11 \%$ in $2007,15 \%$ in 2008, $16 \%$ in 2009 and $18 \%$ in 2010). Similarly, the proportion who says they never do has been declining steadily since $2008(36 \%)$ to reach its lowest recorded level of $26 \%$ in 2010 .

How often do you fear for your own personal safety or security or for that of your family these days? (Q-15) COMPARISON BETWEEN 2006, 2007, 2008, 2009 AND 2010

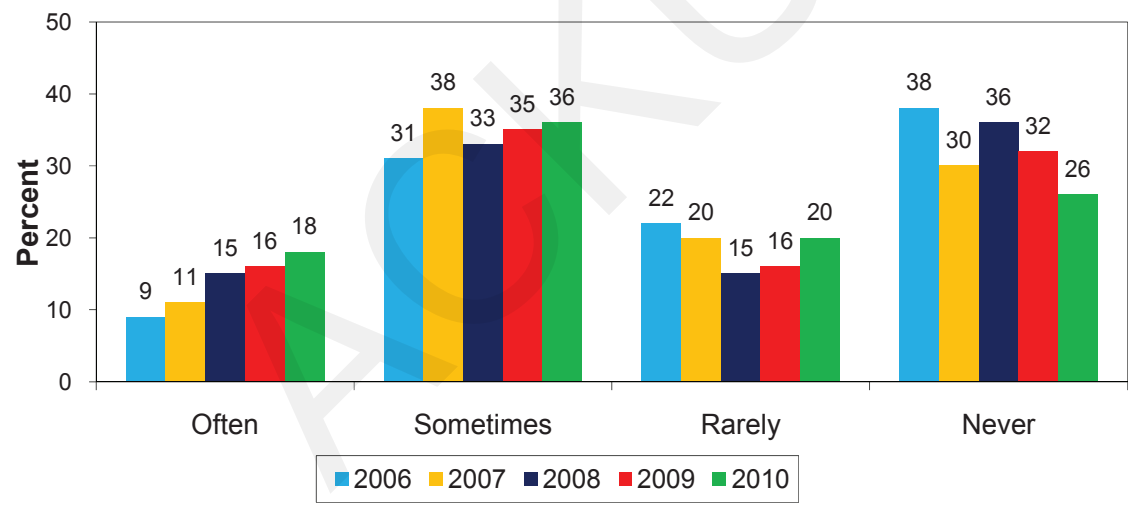

Fig. 3.1

The proportion of respondents who report never having any fear is highest in the Central/Hazarajat (65\%), followed by the North West (45\%) and Central/Kabul (34\%) regions. On the other hand, more than $60 \%$ of respondents report often or sometimes fearing for their safety in the West (66\%), the North East $(64 \%)$ and South East (61\%), and more than half in the South West (55\%), East (51\%) and Central/Kabul (51\%) regions say the same. However the factors that influence these perceptions may differ between regions. The South East and South West record the lowest levels of satisfaction with the security situation in their local area with less than half of respondents in the South East $(42 \%)$ and a little more than a third $(36 \%)$ in the South West judging the security situation in their local area to be good (see Chapter 6, 6.1 Services and Facilities available in local areas). On the other hand, 
while three quarters $(73 \%)$ of respondents in the North East say the security situation is good in their local area (see Chapter 6, 6.1 Services and Facilities available in local areas), the proportion of respondents who report having experienced crime or violence in the last year has almost doubled (from 12\% in 2009 to $20 \%$ in 2010) (see below 3.2 Experience of crime and violence).

How often do you fear for your own personal safety or security or for that of your family these days? (Q-15, Base 6467) BY REGION

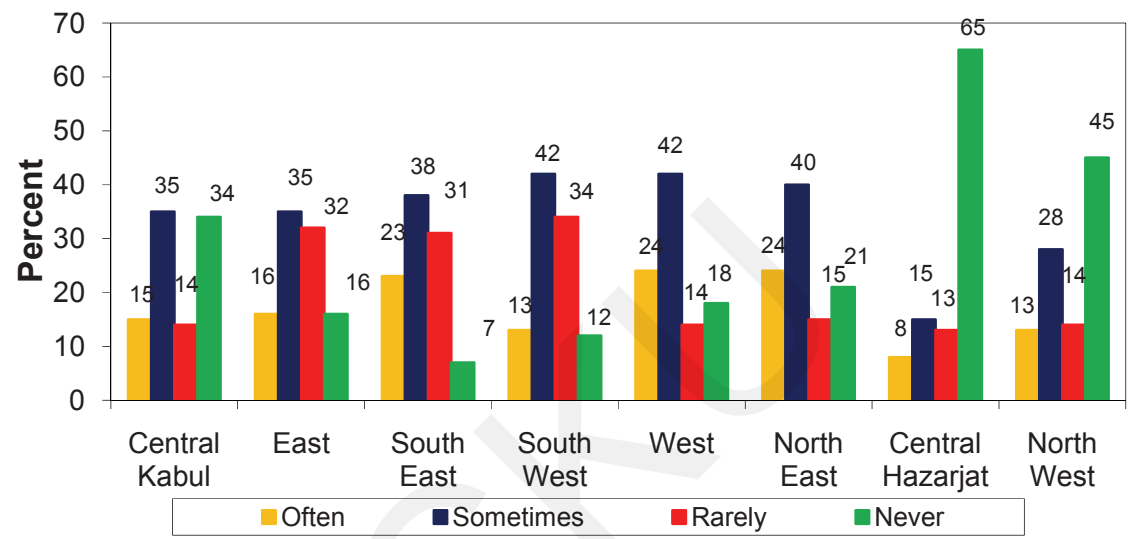

Fig 3.2

\subsection{Experience of crime and violence}

The survey also sought to measure people's actual experience of violence and crime by asking whether they, or anyone in their family, have been a victim of violence or some criminal act in their home or community in the past year. Compared to the proportion of people who report that they sometimes or often fear for their safety (54\%), the proportion of those who have actually experienced violence or crime in the past year is relatively low (17\%), although this group includes just over 1000 individuals.

The proportion of respondents who say they have experienced violence or crime is almost twice as high in rural $(20 \%)$ as in urban $(9 \%)$ areas. This is consistent with the greater concern about insecurity as a major local problem reported by rural $(15 \%)$ compared to urban (6\%) respondents (see Chapter2, 2.5 Afghanistan's biggest problems: Local level).

There are also differences among regions. The highest incidence of crime or violence experienced by respondents is in the South East (34\%), followed by the South 
West (25\%), West (21\%) and North East (20\%). Moreover, while the figure in the South West has been relatively stable over the last few years, there has been a marked rise in the proportion of respondents reporting that they have directly experienced violence or crime in the South East (34\% in 2010 compared to 26\% in 2009 and $21 \%$ in 2008) and in the North East (20\% in 2010 compared to $12 \%$ in 2009 and $15 \%$ in 2008). This may well help to explain the higher levels of fear for personal safety recorded in these regions (see above).

Table 3.1: Have you or has anyone in your family been a victim of violence or of some criminal act in your home or community in the past year? (Q-16) BY REGION, COMPARISON BETWEEN 2008, 2009 AND 2010

\begin{tabular}{|l|c|c|c|} 
& $\begin{array}{c}\mathbf{2 0 0 8} \\
\mathbf{( \% )}\end{array}$ & $\begin{array}{c}\mathbf{2 0 0 9} \\
\mathbf{( \% )}\end{array}$ & $\begin{array}{c}\mathbf{2 0 1 0} \\
\mathbf{( \% )}\end{array}$ \\
\hline Central/Kabul & 13 & 12 & 11 \\
\hline East & 19 & 22 & 18 \\
\hline South East & 21 & 26 & 34 \\
\hline South West & 22 & 25 & 25 \\
\hline West & 17 & 25 & 21 \\
\hline North East & 15 & 12 & 20 \\
\hline Central /Hazarajat & 4 & 10 & 2 \\
\hline North West & 11 & 6 & 6 \\
\hline
\end{tabular}

Respondents who report having been a victim of violence or crime in the past year (17\% of all respondents) were asked about the kinds of violence and crime they or someone in their family had experienced. The most common form of violence or crime mentioned is physical attack or beating (35\%), followed by racketeering/ extortion $(12 \%)$, burglary/looting $(12 \%)$ and theft of livestock $(12 \%)$. Nearly one in ten victims of violence report instances of pick-pocketing $(10 \%)$ or militants/ insurgents actions $(9 \%)$ and one in twenty mention violence resulting from the actions of foreign forces $(6 \%)$,

What kind of violence or crime did you or someone in your family experience in the past year? (Q-17, Base 1114) (percentage based on multiple responses)

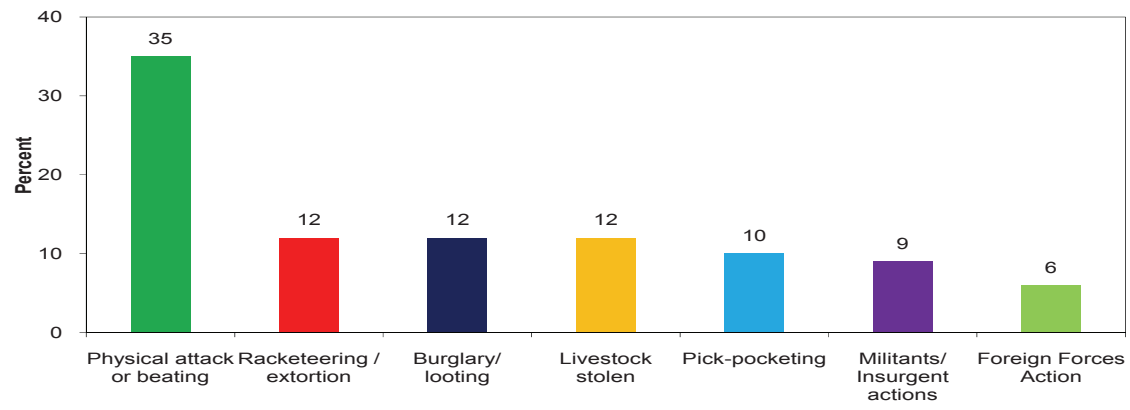

Fig. 3.3 
Over a third (37\%) of crime victims in rural areas report having been victims of physical attack or beating compared to around one in five respondents in urban areas $(22 \%)$. Theft of livestock and pick-pocketing are also more often reported in rural areas. On the other hand, burglary/looting and racketeering/extortion are more prevalent in urban areas.

What kind of violence or crime did you or someone in your family experience in the past year? (Q-17, Base 1114) (Percentage based on multiple responses) BY SETTLEMENT

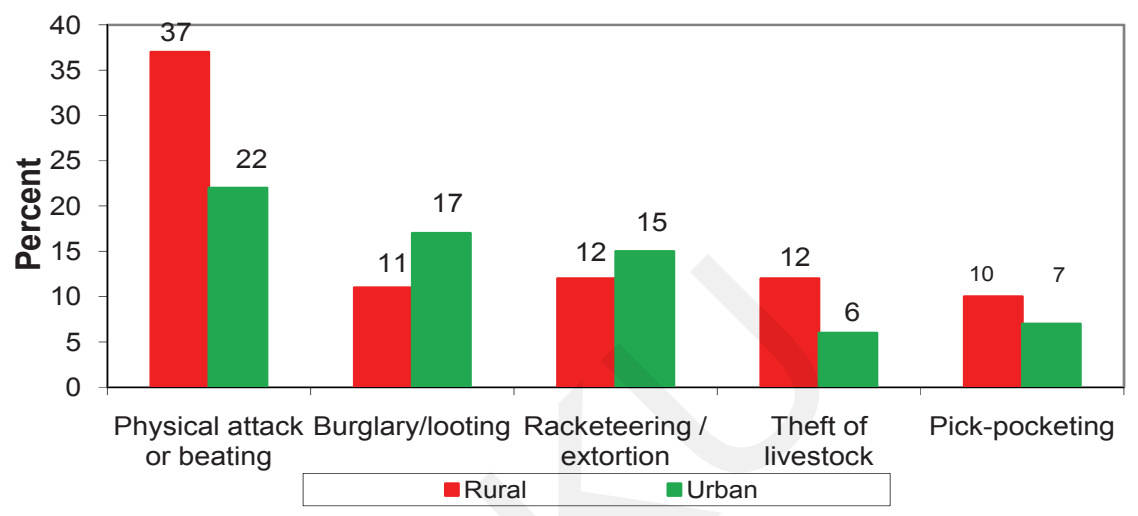

Fig. 3.4

The incidence of victimization from militants/insurgents actions has risen significantly since 2007 (3\%) to around one in ten respondents in 2008 (8\%), 2009 (9\%) and 2010 (9\%). In addition, the experience of conflict-related violence differs significantly among regions. The incidence of victimization from militants/insurgents is highest in the Central/Hazarajat (21\%) followed by the central/Kabul (15\%) regions, and lowest in the South East (4\%).

On the other hand, the experience of violence due to the actions of foreign forces is most often reported in the East (19\%) and the South West (11\%), with no reported cases in the North West or Central/Hazarajat regions.

In addition, around one in twenty respondents report violence or crime as a result of police actions in the North East (7\%), South East (5\%), South West (5\%) and Central/Kabul (5\%) regions. 
What kind of violence or crime did you or someone in your family experience in the past year? (Q-17, Base 1114) (Percentage based on multiple responses) BY REGION

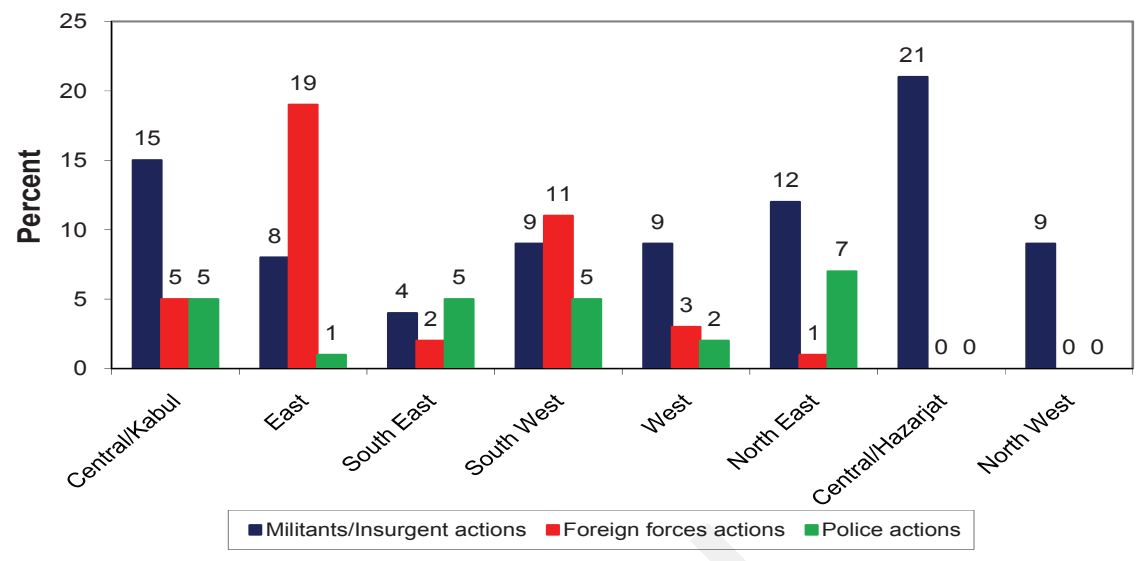

Fig 3.5

\subsection{Attitude toward reporting crime}

Those respondents who have been victims of violence or crime $(17 \%$ of all respondents) were further asked whether they reported the crime to any authority. Just over half $(54 \%)$ cited that they reported the crime, while $30 \%$ say they did not. The percentage of those who say they reported the crime decreased in 2010 (54\%) compared to previous years when it was a little over $60 \%$, whereas those who say they don't know if they reported the crime or not rose substantially (to $15 \%$, from $5 \%$ in $2009,8 \%$ in 2008 and $1 \%$ in 2007).

You said that you've been a victim of violence or a criminal act in the past year. Did you report it to any authority? (Q-18) COMPARISON BETWEEN 2007, 2008, 2009 AND 2010

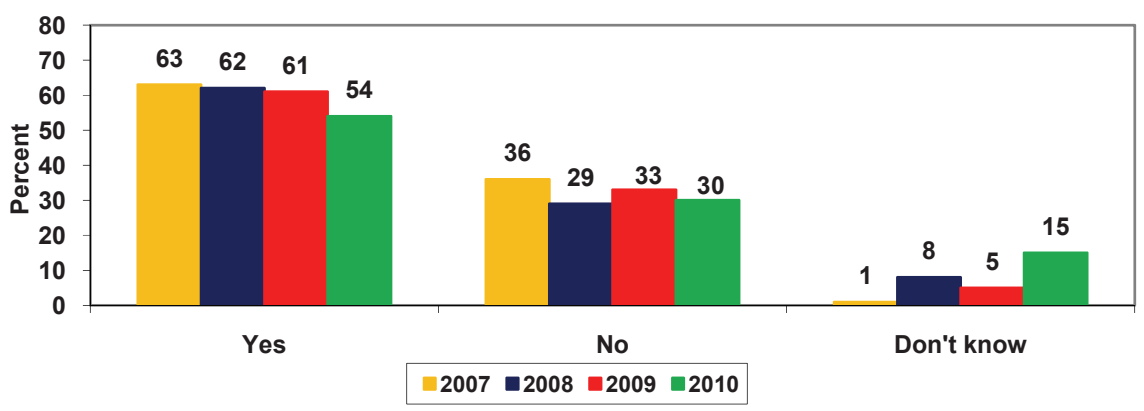

Fig. 3.6 
Respondents who said that they reported violence or crime $(54 \%$ of victims or $9 \%$ of all respondents) were also asked to which agency or institution they reported. Multiple responses were possible. The organization to which respondents most often reported crime is the Afghan National Police (ANP) (37\%). This is consistent with the fact that $70 \%$ of all respondents have confidence in the ANP to arrest those who have committed crimes (see below, 3.5 Perceptions of the Afghan National Police). Respondents also reported crime to other government agencies including the district governor/woleswal (20\%). Around one in eight victims (13\%) reported the incident to the Afghan National Army (ANA). A significant proportion says they reported the crime to informal or traditional institutions such as shura/elders $(18 \%)$, tribal leaders/malik (16\%) and mullahs (8\%).

Respondents in urban areas who have been victims of crime are significantly more likely to report the problem to government institutions such as the ANP $(47 \%$ compared to $36 \%$ in rural areas) or the ANA (19\% compared to $12 \%$ in rural areas). This is likely to be due to the fact that these institutions are more often present in urban settings and are therefore likely to be more accessible to urban residents. On the other hand, rural residents were more likely to report crime to a mullah (9\%) than those in urban areas $(2 \%)$. There is no significant difference in reporting rates to traditional justice mechanisms such as shura/elders and tribal leaders/malik between urban and rural respondents. This is consistent with the fact that local shura and jirga still remain the most trusted and accessible conflict resolution mechanisms for Afghans (see Chapter 10, 10.3 Perceptions on local shura and jirga).

To what agency or institution did you report the crime? (Q-19, Base 602) ALL AND BY SETTLEMENT

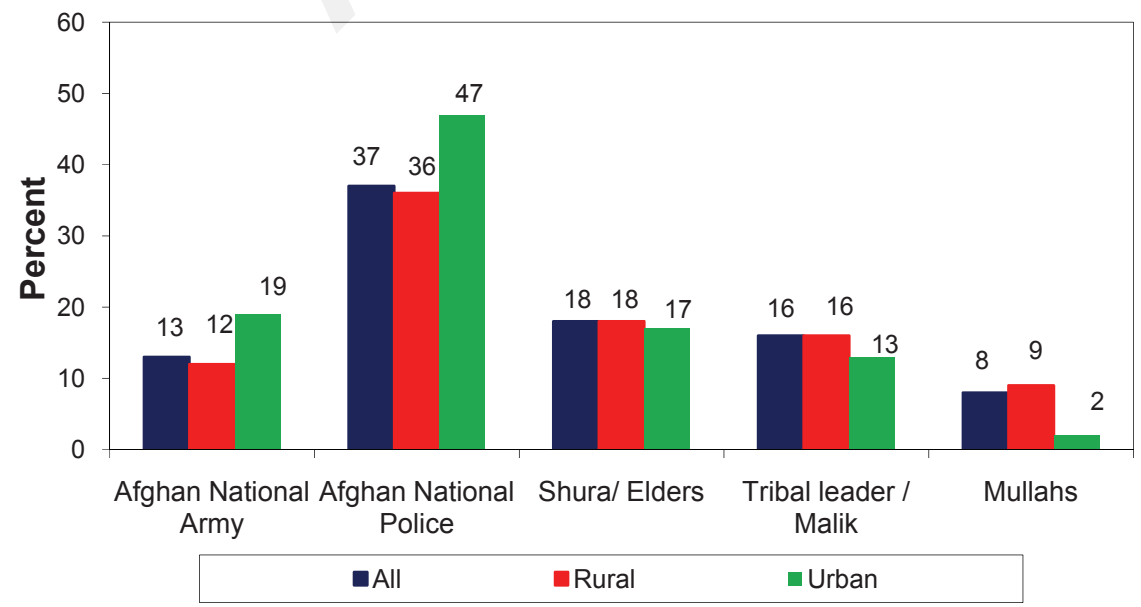

Fig. 3.7 
Respondents, who were victims of crime or violence but did not report it to any authority (i.e., $30 \%$ of victims $/ 5 \%$ of all respondents), were asked to provide reasons why they did not report the crime. Multiple responses were possible. Approximately one quarter $(23 \%)$ say that they did not report the crime because it was not serious. However, a similar proportion $(21 \%)$ says that they were afraid of retaliation. Twice as many rural $(22 \%)$ as urban $(11 \%)$ respondents mentioned danger or fear of retaliation as reason for not reporting crime. A significant proportion (15\%) mentions lack of trust in government officials as the reason for not reporting crime.

Why didn't you report the crime? (Q-20, Base 339)

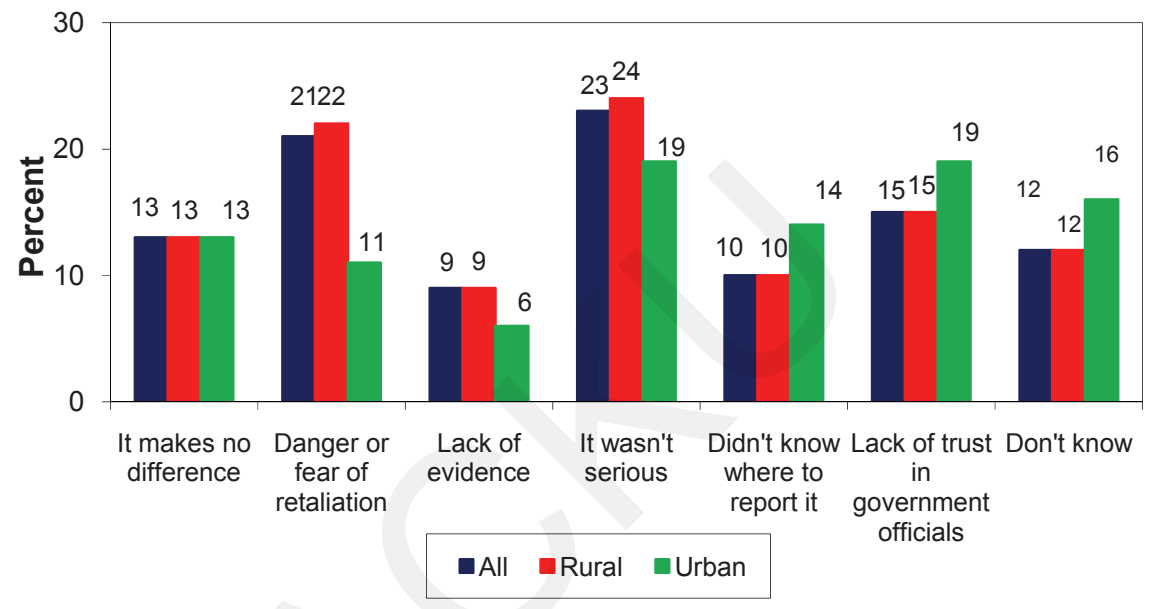

Fig. 3.8

All respondents, regardless of whether they have had personal experience of crime or not, were asked the hypothetical question: "If you were a victim of violence or any criminal act, how much confidence would you have that the governmental law-enforcing organizations and judicial systems would punish the guilty party?" More than half of respondents (57\%) say that they would have some level of confidence (16\% say a great deal of confidence and $41 \%$ say a fair amount of confidence). However, another $24 \%$ say that they would not have very much confidence, and 16\% say they would have no confidence at all.

The majority of respondents in all regions except the South West report overall confidence in government law enforcement agencies, with the highest levels of confidence recorded in the North West (68\%) and North East (62\%). On the other hand, the lowest levels of confidence are recorded in the South West (49\%) and South East (50\%) where nearly half of respondents report having little or no confidence that these agencies would punish those responsible for crime. The Central/Kabul region (21\%) has the highest proportion of respondents who say they have no confidence at all in government law enforcement services, while the lowest proportion is in the North East (9\%). 
If you were a victim of violence or any criminal act, how much confidence would you have that the governmental law-enforcing organizations and judicial systems would punish the guilty party? (Q_21, Base ALL Respondents, 6467) BY REGION

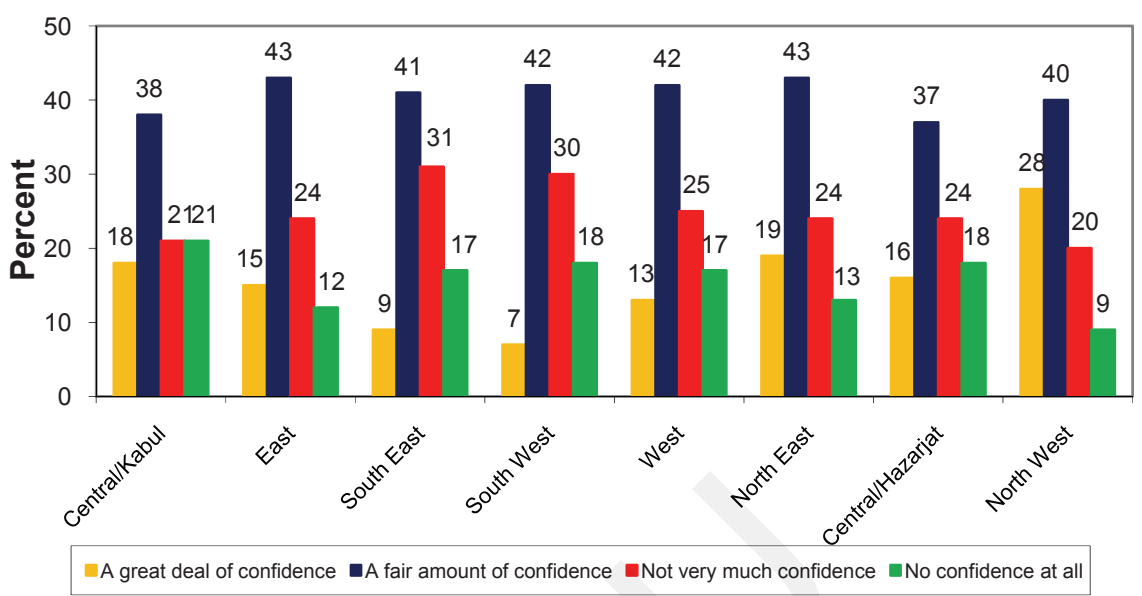

Fig. 3.9

The survey also endeavored to identify what people think are the biggest causes of crime in Afghanistan. The most common causes of crime identified by respondents are unemployment (20\%) and corruption (19\%). Around one in ten respondents identify insecurity $(9 \%)$ amongst the biggest causes of crime. Other factors mentioned include drugs $(6 \%)$, social problems like poverty $(6 \%)$ and illiteracy $(6 \%)$, and governance issues such as weak government $(6 \%)$ and the lack of law and order $(5 \%)$.

Perceptions of the causes of crime differ widely across the regions. Unemployment is the reason most frequently identified in the Central/Kabul (23\%), South West (23\%), North East (20\%) and North West (20\%) regions, whereas corruption is most often mentioned in the East (23\%) and South East (22\%). In the West both unemployment (15\%) and corruption $(16 \%)$ are seen as the principal causes of crime. Poverty is highlighted in the Central/Hazarajat (11\%), and illiteracy in the Central/ Hazarajat $(14 \%)$ and South West $(11 \%)$, whereas drugs are most often mentioned in the East (9\%). The lack of law enforcement is also emphasized in the Central/ Hazarajat region (13\%), while weak government generally is most often mentioned in the North East (9\%). 
Table 3.2: What is the biggest cause of crime in Afghanistan? (Q_22a, Base, 6467) BY REGION

\begin{tabular}{|c|c|c|c|c|c|c|c|c|c|}
\hline & $\begin{array}{l}\text { All } \\
(\%)\end{array}$ & $\begin{array}{c}\text { Central/ } \\
\text { Kabul } \\
(\%)\end{array}$ & $\begin{array}{l}\text { East } \\
(\%)\end{array}$ & $\begin{array}{c}\text { South } \\
\text { East } \\
(\%)\end{array}$ & $\begin{array}{c}\text { South } \\
\text { West } \\
(\%)\end{array}$ & $\begin{array}{l}\text { West } \\
(\%)\end{array}$ & $\begin{array}{c}\text { North } \\
\text { East } \\
(\%)\end{array}$ & $\begin{array}{c}\text { Central/ } \\
\text { Hazarajat } \\
(\%)\end{array}$ & $\begin{array}{c}\text { North } \\
\text { West } \\
(\%)\end{array}$ \\
\hline Unemployment & 20 & 23 & 17 & 18 & 23 & 15 & 20 & 13 & 20 \\
\hline Corruption & 19 & 21 & 23 & 22 & 18 & 16 & 18 & 8 & 17 \\
\hline Insecurity & 9 & 7 & 9 & 7 & 13 & 11 & 6 & 7 & 9 \\
\hline Poverty & 6 & 8 & 3 & 5 & 3 & 5 & 8 & 11 & 9 \\
\hline Illiteracy & 6 & 5 & 6 & 5 & 11 & 4 & 6 & 14 & 9 \\
\hline Drugs & 6 & 6 & 4 & 9 & 3 & 6 & 6 & 5 & 6 \\
\hline $\begin{array}{l}\text { Lack of Government } \\
\text { attention / weak } \\
\text { Government }\end{array}$ & 6 & 7 & 6 & 7 & 5 & 6 & 9 & 6 & 3 \\
\hline $\begin{array}{l}\text { Lack of law } \\
\text { implementation }\end{array}$ & 5 & 5 & 5 & 8 & 3 & 9 & 5 & 13 & 3 \\
\hline
\end{tabular}

\subsection{Fear to participate in various activities}

The survey also measured perceptions of security by discovering whether people are afraid to participate in a range of public activities. A series of activities was read to respondents and they were asked to say whether they would participate in these activities with some degree of fear or without fear. Half of respondents $(51 \%)$ say that they would have no fear participating in resolving problems in their community. This is the only activity in which a majority of people say they can participate without fear. Only $39 \%$ of respondents say they would have no fear voting in a national election, and only $28 \%$ say they would have no fear participating in a peaceful demonstration, or running for public office. The proportion of respondents who say they would not be afraid when traveling from one part of the country to another is the lowest at $24 \%$.

A majority $(52 \%)$ of respondents say they would feel fear when encountering ANP officers, including 19\% who say they would feel a lot of fear. This could be related to the fact that half of the respondents who had contact with ANP officers in the last year report having encountered some level of corruption in the form of payment of bribes (see Chapter 8, 8.2 Payment of bribes) 
Table 3.3: Public's level of fear to participate in various activities (Q-26a-f, Base 6467)

\begin{tabular}{l|c|c|c|} 
& $\begin{array}{c}\text { No fear } \\
(\mathbf{\%})\end{array}$ & $\begin{array}{c}\text { Some fear } \\
\mathbf{( \% )}\end{array}$ & $\begin{array}{c}\text { A lot of fear } \\
(\mathbf{\%})\end{array}$ \\
\hline $\begin{array}{l}\text { a) When participating in resolving problems in } \\
\text { your community }\end{array}$ & 51 & 35 & 11 \\
\hline b) Voting in a national election & 39 & 39 & 21 \\
\hline c) Participating in a peaceful demonstration & 28 & 39 & 28 \\
\hline d) To run for a public office & 28 & 38 & 26 \\
\hline e) When encountering ANP officers & 45 & 33 & 19 \\
\hline $\begin{array}{l}\text { f) When traveling from one part of Afghanistan } \\
\text { to another part of the country }\end{array}$ & 24 & 42 & 32 \\
\hline
\end{tabular}

Fear to participate in the listed activities is particularly high in the South West and South East where around four respondents in five say they would be afraid to vote in a national election (78\% in the South East, $83 \%$ in the South West), participate in a peaceful demonstration ( $84 \%$ in the South East, $79 \%$ in the South West), or run for political office $(79 \%$ in the South East, $83 \%$ in the South West). Similar proportions say the same about traveling to another part of the country $(88 \%$ in the South East, $80 \%$ in the South West). These are also the regions where insecurity is most often identified as a major local problem (see Chapter 2, 2.5 Afghanistan's biggest problems: Local level), and where the majority of respondents say that the security situation is bad in their local area (see Chapter 6, 6.1 Services and Facilities available in local areas). Around three quarters of respondents in the East also report fear to participate in these activities, and the proportion is closer to two-thirds in the West and North East.

The lowest levels of fear are recorded in the Central/Hazarajat for all listed activities except traveling from one part of the country to another, followed by the North West and the Central/Kabul region. 
Table 3.4: Public's level of fear (combination of some fear and a lot of fear) to participate in various activities (Q-26a-f, Base 6467) BY REGION

\begin{tabular}{|c|c|c|c|c|c|c|c|c|}
\hline & $\begin{array}{c}\text { Central } \\
\text { /Kabul } \\
(\%)\end{array}$ & $\begin{array}{l}\text { East } \\
(\%)\end{array}$ & $\begin{array}{c}\text { South } \\
\text { East } \\
(\%)\end{array}$ & $\begin{array}{c}\text { South } \\
\text { West } \\
(\%)\end{array}$ & $\begin{array}{l}\text { West } \\
(\%)\end{array}$ & $\begin{array}{c}\text { North } \\
\text { East } \\
(\%)\end{array}$ & $\begin{array}{c}\text { Central/ } \\
\text { Hazarajat } \\
(\%)\end{array}$ & $\begin{array}{c}\text { North } \\
\text { West } \\
(\%)\end{array}$ \\
\hline $\begin{array}{l}\text { a) Participating in resolving } \\
\text { problems in your com- } \\
\text { munity }\end{array}$ & 36 & 55 & 53 & 65 & 56 & 47 & 23 & 30 \\
\hline $\begin{array}{l}\text { b) Voting in a national } \\
\text { election }\end{array}$ & 47 & 69 & 78 & 83 & 64 & 62 & 34 & 41 \\
\hline $\begin{array}{l}\text { c) Participating in a peace- } \\
\text { ful demonstration }\end{array}$ & 61 & 72 & 84 & 79 & 68 & 69 & 39 & 54 \\
\hline $\begin{array}{l}\text { d) Running for public } \\
\text { office }\end{array}$ & 54 & 74 & 79 & 83 & 67 & 67 & 31 & 51 \\
\hline $\begin{array}{l}\text { e) Encountering ANP } \\
\text { officers }\end{array}$ & 42 & 57 & 65 & 82 & 61 & 47 & 32 & 36 \\
\hline $\begin{array}{l}\text { f) Traveling from one part } \\
\text { of Afghanistan to another } \\
\text { part of the country }\end{array}$ & 68 & 73 & 88 & 80 & 75 & 76 & 69 & 63 \\
\hline
\end{tabular}

Levels of fear to participate in public activities are rising steadily over time. The proportion of respondents who say they would have some fear participating in resolving problems in their community has risen from 32\% in 2006 to $46 \%$ in 2010 . The same is true for voting in a national election (from $41 \%$ in 2006 to $60 \%$ in 2010), with a particularly large rise since 2009 (51\%) when the elections were accompanied by reports of intimidation of voters by anti-government militants, and accusations of widespread electoral malpractice. A similar trend is visible for other public activities such as running for public office (from 50\% in 2006 to 64\% in 2010) and to a lesser extent for participating in a peaceful demonstration (from 61\% in previous years to $67 \%$ in 2010). The proportion of respondents who report being afraid to travel from one part of the country to another is also rising steadily from $61 \%$ in 2008 and $64 \%$ in 2009 to $74 \%$ in 2010 .

Only the levels of fear related to encountering ANP officers has remained mostly stable, although even here a small rise is evident (from 49\% in 2007 and 2008 to $52 \%$ in 2010$)$. 
Table 3.5: Public's level of fear (combination of some fear and a lot of fear) to participate in various activities (Q-26a-f) COMPARISON BETWEEN 2006, 2007, 2008, 2009 AND 2010

\begin{tabular}{|l|c|c|c|c|c|} 
& $\begin{array}{c}2006 \\
(\%)\end{array}$ & $\begin{array}{c}\mathbf{2 0 0 7} \\
(\%)\end{array}$ & $\begin{array}{c}\mathbf{2 0 0 8} \\
(\%)\end{array}$ & $\begin{array}{c}\mathbf{2 0 0 9} \\
(\%)\end{array}$ & $\begin{array}{c}\mathbf{2 0 1 0} \\
(\%)\end{array}$ \\
\hline $\begin{array}{l}\text { a) When participating in resolving problems in } \\
\text { your community }\end{array}$ & 32 & 38 & 39 & 40 & 46 \\
\hline $\begin{array}{l}\text { b) Voting in a national election } \\
\text { c) Participating in a peaceful demonstration }\end{array}$ & 41 & 44 & 45 & 51 & 60 \\
\hline $\begin{array}{l}\text { d) To run for a public office } \\
\text { e) When encountering ANP officers }\end{array}$ & 50 & 56 & 55 & 58 & 64 \\
\hline $\begin{array}{l}\text { f) When traveling from one part of Afghanistan } \\
\text { to another part of the country }\end{array}$ & - & - & 61 & 69 & 74 \\
\hline
\end{tabular}

\subsection{Perceptions of the Afghan National Police}

The institution in Afghanistan that is primarily responsible for ensuring security and fighting crime and violence is the Afghan National Police (ANP). The survey attempted to understand public perceptions of the ANP in various dimensions such as its honesty, fairness, professionalism, efficiency to arrest criminals and capacity to act without the assistance of foreign troops. A series of statements about the ANP was read out to respondents and they were asked to state whether they agree or disagree. The responses to these statements are summarized in the table below.

Table 3.6: Public agreement and disagreement with statements about the ANP (Q-36a-e, Base 6467)

\begin{tabular}{|c|c|c|c|c|}
\hline & $\begin{array}{l}\text { Strongly } \\
\text { agree } \\
(\%)\end{array}$ & $\begin{array}{c}\text { Agree } \\
\text { somewhat } \\
(\%)\end{array}$ & $\begin{array}{l}\text { Disagree } \\
\text { somewhat } \\
\quad(\%)\end{array}$ & $\begin{array}{l}\text { Strongly } \\
\text { disagree } \\
(\%)\end{array}$ \\
\hline $\begin{array}{l}\text { a) ANP is honest and fair with the Afghan } \\
\text { people }\end{array}$ & 44 & 40 & 12 & 4 \\
\hline b) ANP is unprofessional and poorly trained & 20 & 38 & 29 & 11 \\
\hline $\begin{array}{l}\text { c) ANP needs the support of foreign troops } \\
\text { and cannot operate by itself }\end{array}$ & 28 & 41 & 21 & 8 \\
\hline d) ANP helps improve the security & 37 & 40 & 15 & 6 \\
\hline $\begin{array}{l}\text { e) ANP is efficient at arresting those who } \\
\text { have committed crimes so that they can be } \\
\text { brought to justice }\end{array}$ & 30 & 40 & 21 & 8 \\
\hline
\end{tabular}


The Afghan public's assessment of the ANP is mostly positive. More than four out of five respondents agree that the ANP is honest and fair with the Afghan people $(84 \%)$ and more than three quarters think the ANP helps to improve security $(77 \%)$. Seventy percent of respondents believe that the ANP is efficient in arresting those who have committed crimes so they can be brought to justice. However, a similar proportion $(69 \%)$ agrees that the ANP needs the support of foreign troops and cannot operate by itself. A majority (58\%) also think that the ANP is unprofessional and poorly trained.

Public perceptions of the operational capacity of the ANP have been improving since 2007. Fewer respondents now think that the ANP is unprofessional and poorly trained (58\% in 2009 and 2010 compared to 65\% in 2007 and 60\% in 2008) or that it needs the support of foreign troops to operate (69\%-70\% between 2010 and 2008 compared to $77 \%$ in 2007). However, this does not translate into significantly greater satisfaction with police performance. The proportions of respondents who agree that the ANP is honest and fair, or efficient at arresting those who have committed crime, have remained basically stable since 2008. However there has been a significant fall in the last year in the proportion who agree that the ANP helps to improve security (77\% in 2010 compared to $82 \%$ in 2009 , $80 \%$ in 2008 and $86 \%$ in 2007). This again highlights ongoing concerns about insecurity which is consistently identified as the most important problem facing the country (see Chapter 2, 2.4 Afghanistan's biggest problems: National level).

Table 3.7: Public agreement (strongly agree and agree somewhat) with statements about the ANP (Q-36a-e) COMPARISON BETWEEN 2007, 2008, 2009 AND 2010

\begin{tabular}{|c|c|c|c|c|}
\hline & \multicolumn{4}{|c|}{$\begin{array}{c}\text { Agree }(\%) \\
\text { (Strongly agree \& agree somewhat) }\end{array}$} \\
\hline & 2007 & 2008 & 2009 & 2010 \\
\hline $\begin{array}{l}\text { a) ANP is honest and fair with the } \\
\text { Afghan people }\end{array}$ & 86 & 80 & 83 & 84 \\
\hline $\begin{array}{l}\text { b) ANP is unprofessional and poorly } \\
\text { trained }\end{array}$ & 65 & 60 & 58 & 58 \\
\hline $\begin{array}{l}\text { c) ANP needs the support of foreign } \\
\text { troops and cannot operate by itself }\end{array}$ & 77 & 69 & 70 & 69 \\
\hline d) ANP helps improve the security & 86 & 80 & 82 & 77 \\
\hline $\begin{array}{l}\text { e) ANP is efficient at arresting those } \\
\text { who have committed crimes so that } \\
\text { they can be brought to justice }\end{array}$ & - & 73 & 71 & 70 \\
\hline
\end{tabular}




\subsection{Perceptions of the Afghan National Army}

The survey also sought to measure public perceptions of the other most significant national security force, the Afghan National Army (ANA). A similar series of statements about the ANA were read out to respondents and they were asked to indicate whether they agree or disagree. The responses to these statements are summarized in the table below.

Table 3.8: Public agreement and disagreement with statements about the $A N A(Q-35 a-d$, Base 6467)

\begin{tabular}{l|c|c|c|c|} 
& $\begin{array}{c}\text { Strongly } \\
\text { Agree } \\
(\mathbf{0})\end{array}$ & $\begin{array}{c}\text { Agree } \\
\text { somewhat } \\
(\mathbf{\%})\end{array}$ & $\begin{array}{c}\text { Disagree } \\
\text { somewhat } \\
\mathbf{( \% )}\end{array}$ & $\begin{array}{c}\text { Strongly } \\
\text { disagree } \\
\mathbf{( \% )}\end{array}$ \\
\hline a) ANA is honest and fair with the Afghan people & 58 & 34 & 6 & 2 \\
\hline $\begin{array}{l}\text { b) ANA is unprofessional and poorly trained } \\
\text { c) ANA needs the support of foreign troops and } \\
\text { cannot operate by itself }\end{array}$ & 18 & 33 & 30 & 17 \\
\hline d) ANA helps improve the security & 30 & 40 & 21 & 8 \\
\hline
\end{tabular}

Overall, the public has an even more positive assessment of the ANA than it does of the ANP. Nine out of ten respondents $(92 \%)$ agree that the ANA is honest and fair with the Afghan people, compared to around eight out of ten (84\%) who say the same about the ANP. A similarly high proportion agree that the ANA is helping to improve the security situation in the country (86\%), compared to $77 \%$ for the ANP. However, as with the ANP, a high proportion of respondents also think that the ANA needs the support of foreign troops and cannot operate by itself $(70 \%)$. Around half $(52 \%)$ agree that the ANA is unprofessional and poorly trained.

As with the ANP, perceptions of the operational capacity of the ANA have remained basically stable over the last three years, however, unlike the ANP, perceptions of the ANA's performance, including in helping to improve security, also remain stable.

Table 3.9: Public agreement (strongly agree and agree somewhat) with statements about the ANA (Q-35a-d) COMPARISON BETWEEN 2007, 2008, 2009 AND 2010

\begin{tabular}{|c|c|c|c|c|}
\hline & \multicolumn{4}{|c|}{$\begin{array}{c}\text { Agree }(\%) \\
\text { (Strongly agree \& agree somewhat) }\end{array}$} \\
\hline & 2007 & 2008 & 2009 & 2010 \\
\hline $\begin{array}{l}\text { a) ANA is honest and fair with the Afghan } \\
\text { people }\end{array}$ & 90 & 89 & 91 & 92 \\
\hline b) ANA is unprofessional and poorly trained & 62 & 55 & 52 & 52 \\
\hline $\begin{array}{l}\text { c) ANA needs the support of foreign troops and } \\
\text { cannot operate by itself }\end{array}$ & 77 & 69 & 69 & 69 \\
\hline d) ANA helps improve the security & 89 & 86 & 87 & 86 \\
\hline
\end{tabular}


These results mirror the finding that there has been a slight deterioration in public confidence in the police in 2010 but not in the army (see Chapter 7.1: Confidence with various institutions). One reason for this could be the greater degrees of interaction of the public with the police which provides both positive and negative experiences. Indeed, in parts of the country where the ANA is particularly active and involved in military operations and house searches, opinions about their performance tend to be less positive. For instance, in the South West, 31\% of respondents disagree with the statement that the ANA helps to improve security, including $42 \%$ in, Kandahar, $41 \%$ in Zabul and 26\% in Helmand provinces which represent the highest proportions anywhere in the country. 


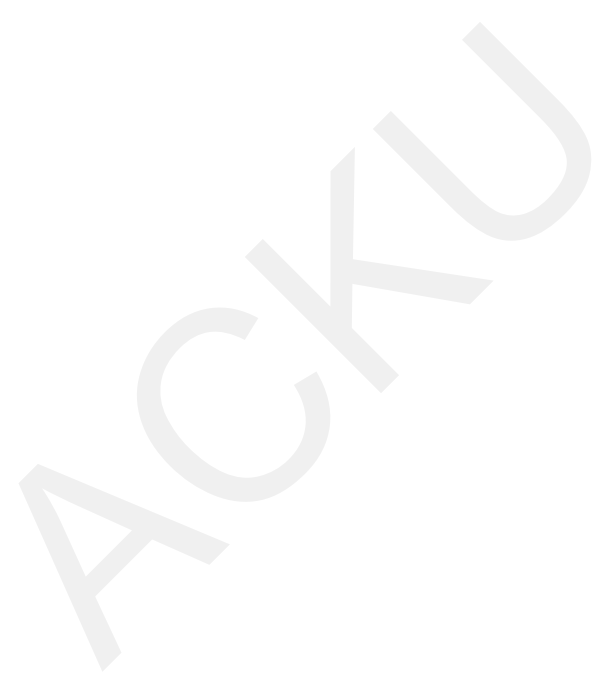




\section{Reconciliation and Reintegration}

\subsection{Perceptions of the government's reconciliation efforts}

The survey asked respondents whether they approve or disapprove of the current government efforts at negotiation and reconciliation with armed anti-government elements. A large majority of respondents (83\%) say they approve of these efforts, with $42 \%$ strongly in favor and $41 \%$ somewhat in favor. The level of support for reconciliation with armed opposition groups has risen significantly since 2009 when less than three quarters of respondents $(71 \%)$ said they approved. This rise could suggest that an increasing proportion of the Afghan public favors a political solution to the ongoing conflict in the country, rather than a purely military one.

Do you strongly agree, agree somewhat, disagree somewhat or strongly disagree with the Government's reconciliation efforts and negotiations with the armed opposition? (Q-42) COMPARISON BETWEEN 2009 AND 2010

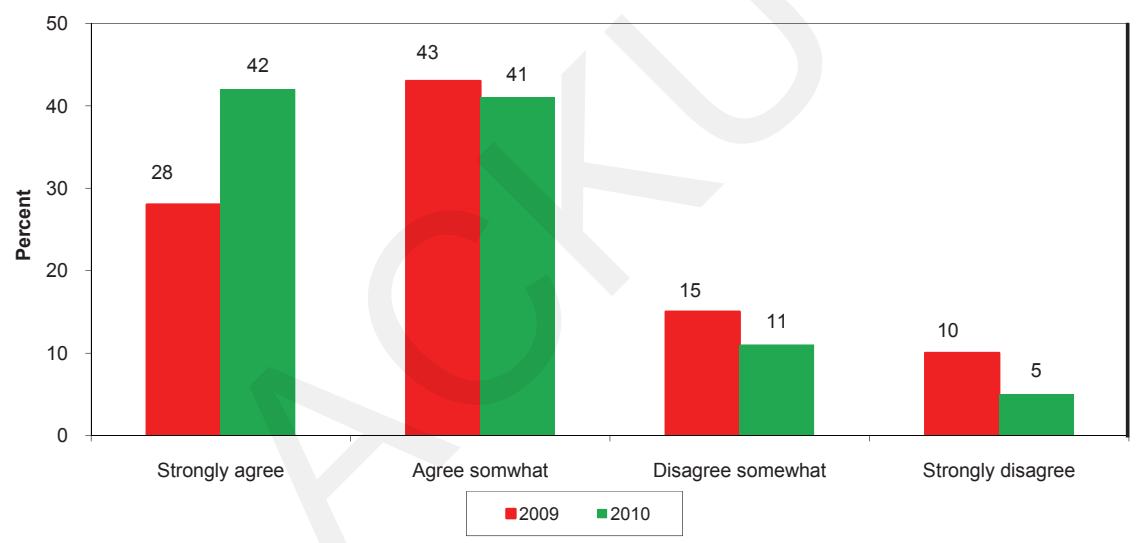

Fig. 4.1

Men are more supportive of the reintegration efforts than women. While almost nine out of ten male respondents $(88 \%)$ say they agree with this approach, including half $(50 \%)$ who strongly agree, this is true for just under eight out of ten women $(78 \%)$, including a third $(33 \%)$ who strongly agree. Almost twice as many women $(20 \%)$ as men $(12 \%)$ say they oppose these efforts. These findings may indicate a level of concern amongst Afghan women regarding a negotiated settlement with the Taliban, whose regime imposed major restrictions on women's participation in Afghan society at all levels.

Support for the government's reconciliation efforts and negotiations with the armed opposition are high in all regions. Support is highest in the East (89\%), South East $(85 \%)$ and North West (85\%) and lowest in the Central/Hazarajat region (78\%). 
Do you strongly agree, agree somewhat, disagree somewhat or strongly disagree with the Government's reconciliation efforts and negotiations with the armed opposition? $(242,6467) B Y$ REGION

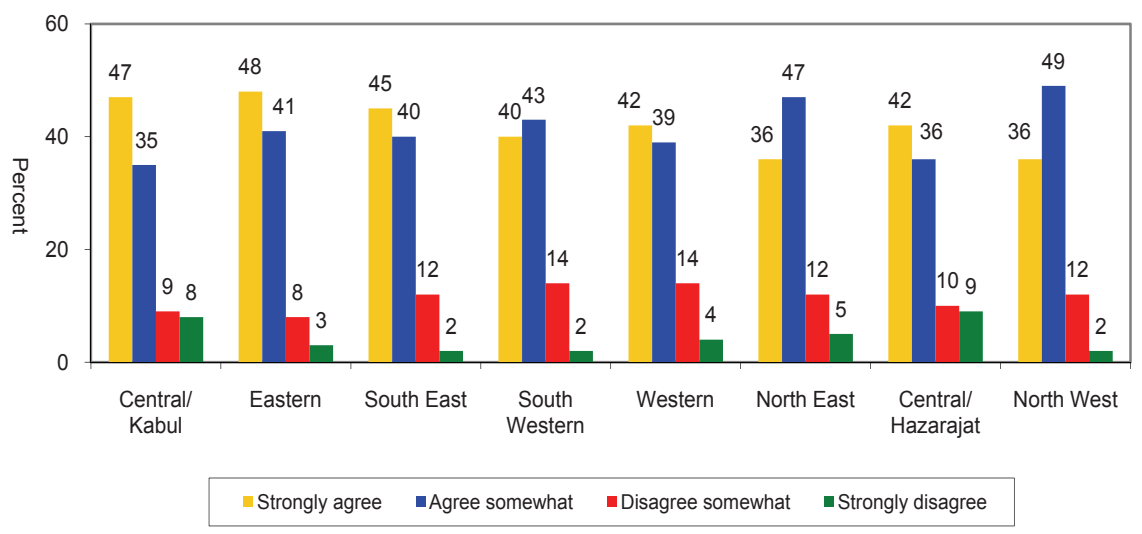

Fig. 4.2

Respondents were also asked whether they think that the government's reconciliation efforts and negotiations will help stabilize the country. Around three quarters $(73 \%)$ of respondents say they think this is the case. Only $23 \%$ think not.

Again men and women have significantly different views. While almost-four fifths $(79 \%)$ of men say the reintegration efforts will help stabilize the country this is true for only two-thirds of women $(66 \%)$. Twenty-eight percent of women say reintegration will not bring stability, compared to $18 \%$ of men.

Even though the majority of respondents in all regions think the government's efforts and negotiations will help stabilize the country, the proportion who think so is significantly higher in the Central/Hazarajat region (84\%), where support for negotiations is the lowest. This suggests that the lower levels of support for the government's reintegration efforts in this region are not related to concerns about security and stability.

Do you think the Afghan Government's reconciliation efforts and negotiations will help stabilize the country? (Q 43, Base 6467) BY REGION

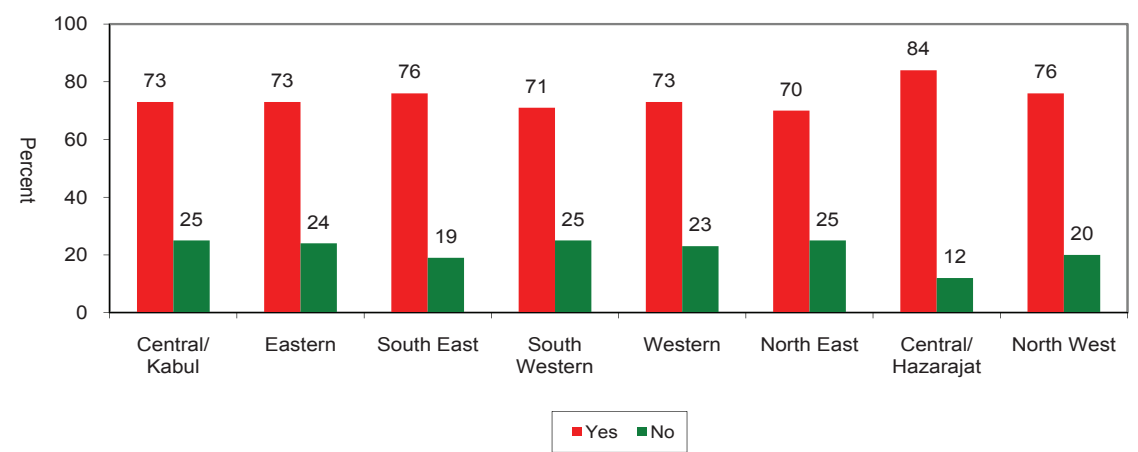

Fig. 4.3 
Respondents were then asked whether they agree or disagree that those anti-government elements who lay down arms and express willingness to reintegrate into society should be provided with government assistance, jobs and housing. Four out of five respondents (81\%) agree with this approach, including 40\% who strongly agree, while $18 \%$ disagree.

Here too there has been a significant rise in support for the government's reintegration approach. In 2009, $71 \%$ of respondents agreed with the provision of assistance for those who choose to lay down their arms and reintegrate into society, compared to $81 \%$ in 2010. In $200928 \%$ strongly agreed with this approach, whereas in 2010 this has risen to $40 \%$. Overall disagreement with this approach has fallen from $25 \%$ to $18 \%$, while strong disagreement has halved, from $10 \%$ in 2009 to $5 \%$ in 2010 .

Do you strongly agree, agree somewhat, disagree somewhat or strongly disagree that those Anti-Government elements who lay down arms and express willingness to reintegrate into society be provided with government assistance, jobs and housing? (Q-44) COMPARISON 2009 and 2010

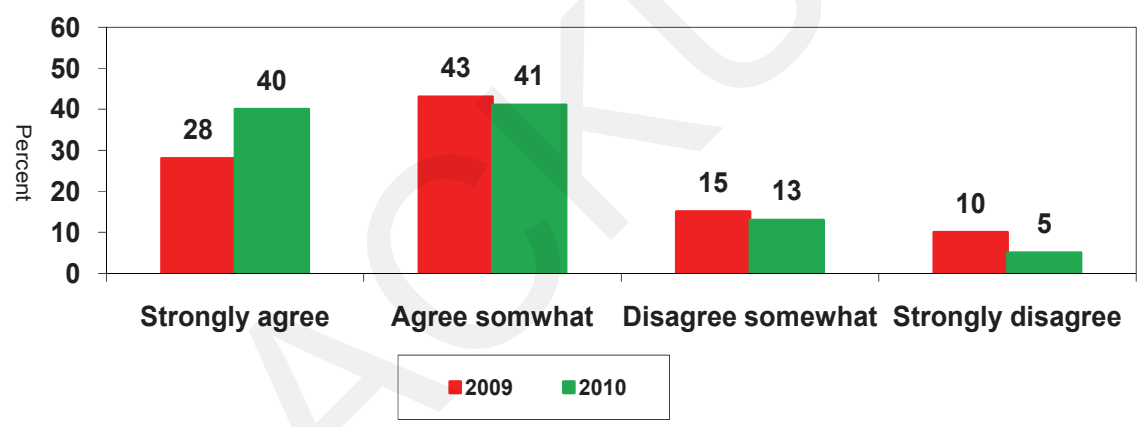

Fig. 4.4

In 2010, support for government assistance to former militants who choose to reintegrate is highest amongst Uzbek (88\%) and Pashtun (83\%) ethnic groups. Support is lowest amongst Hazara (76\%) and respondents from other ethnic groups $(75 \%)$, although three quarters of respondents in both these groups still support the government's approach. 
Do you strongly agree, agree somewhat, disagree somewhat, or strongly disagree those Anti-Government elements who lay arms and express willingness to reintegrate into society to be provided government assistance, jobs and housing? (Q 44, Base 6467) BY ETHNICITY

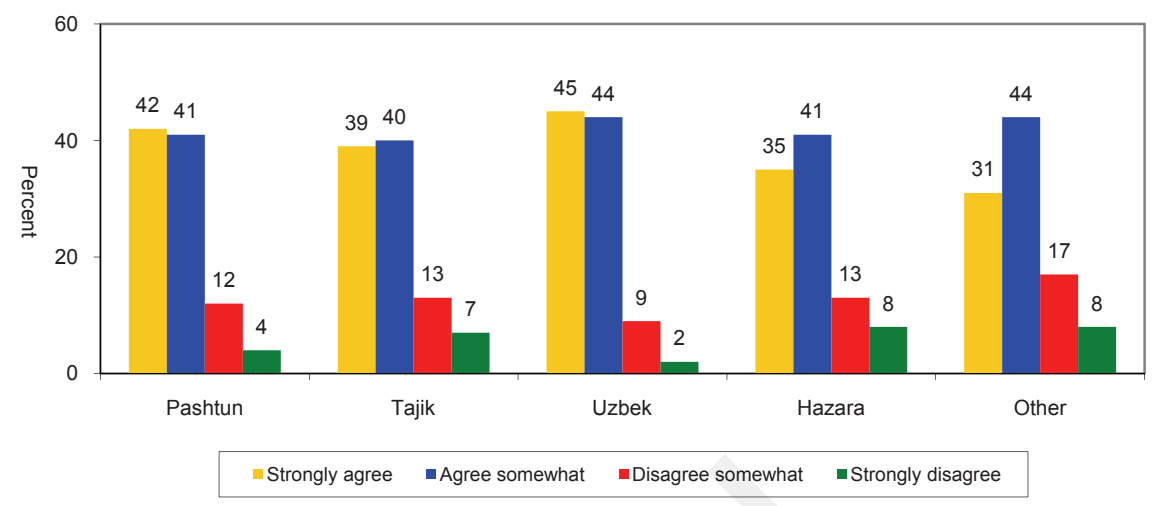

Fig. 4.5

At the regional level, there is over $80 \%$ support for the government's reintegration efforts in all regions except the North East (79\%) and Central/Kabul (77\%) where the level of support is only slightly lower. The highest levels of support are in the East $(87 \%)$ followed by the West (84\%). These are also amongst the regions that record the highest levels of sympathy for armed opposition groups (see following section, 4.2 Sympathy with armed opposition groups).

Do you strongly agree, agree somewhat, disagree somewhat, or strongly disagree those Anti-Government elements who lay arms and express willingness to reintegrate into society to be provided government assistance, jobs and housing? (Q 44, Base 6467) BY REGION

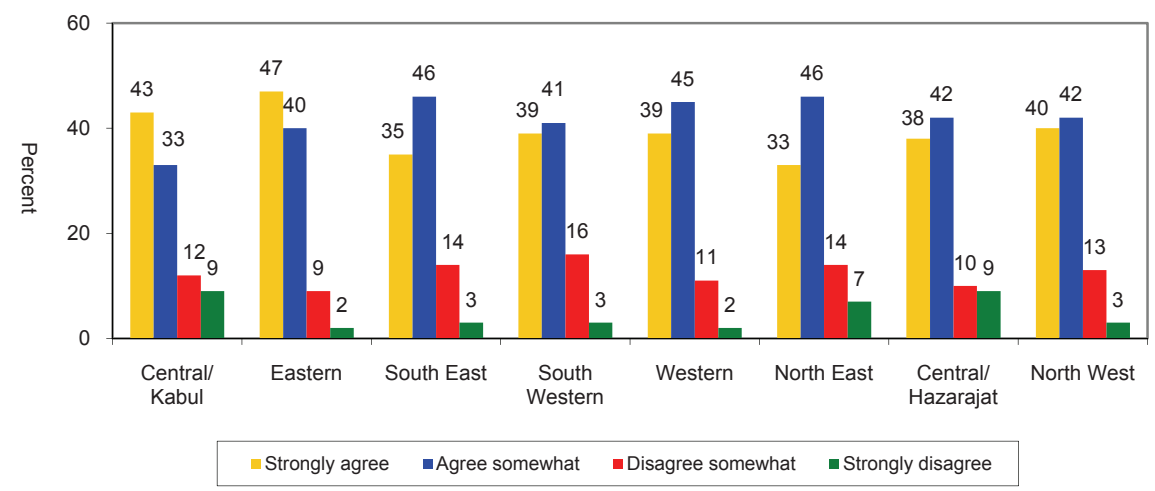

Fig. 4.6 


\subsection{Sympathy with armed opposition groups}

The survey also endeavored to measure public sympathy toward armed anti-government groups. The survey asked all respondents the following question: "Thinking about the reasons the armed opposition used violence during the past year, would you say that you in general have a lot of sympathy, a little sympathy, or no sympathy at all for these anti-government groups?" In total, $40 \%$ percent of respondents say they have some level of sympathy with the motivations of armed opposition groups, including 14\% who say that they have a lot of sympathy. Sympathy for armed opposition groups has fallen significantly since 2009 when the majority of respondents $(56 \%)$ said they had some level of sympathy with them, including $22 \%$ who said a lot of sympathy.

In 2010, the majority of respondents (55\%) say they have no sympathy at all with the use of violence by armed opposition groups. This has risen significantly since 2009 when just over a third $(36 \%)$ of respondents said this.

Thinking about the reasons the armed opposition used violence during the past year, would you say that you in general have a lot of sympathy, a little sympathy, or no sympathy at all for these antigovernment groups? (Q-45) COMPARISON 2009 and 2010

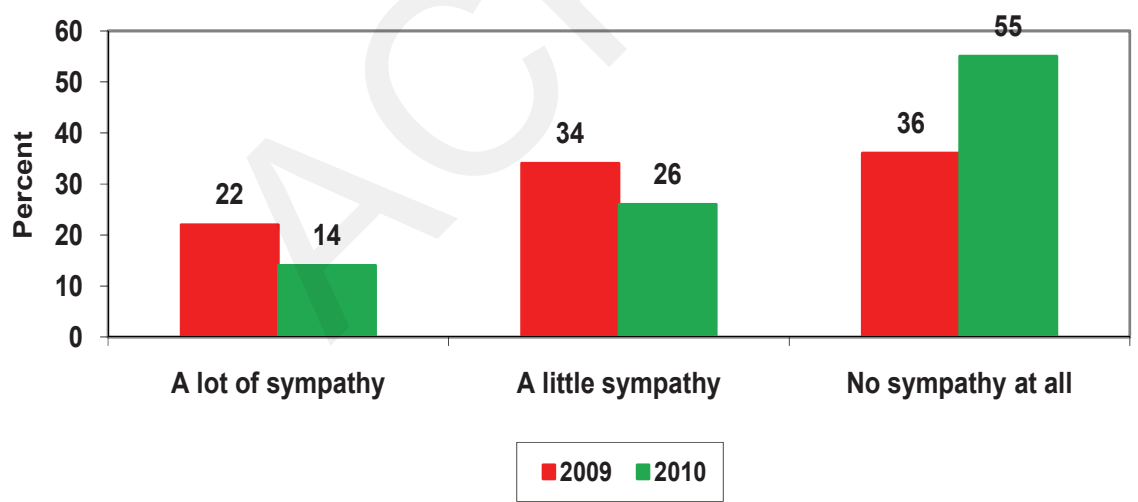

Fig. 4.7

More women say they have no sympathy at all with armed opposition groups $(59 \%)$ than men $(52 \%)$, whereas more men say they have a lot of sympathy $(17 \%)$ than women $(11 \%)$.

Approximately two-thirds of urban respondents (66\%) say they have no sympathy at all for armed opposition groups, but this is true for just over half of rural respondents $(52 \%)$. 
In terms of ethnicity, almost half of Pashtun respondents (49\%) say they have some sympathy with armed opposition groups, compared to around a third of Uzbeks $(36 \%)$ and Tajiks $(32 \%)$ and just over a quarter $(27 \%)$ of Hazara respondents. Sympathy is also relatively high amongst respondents from other ethnic groups (41\%). Those reporting that they have no sympathy at all for the anti-government groups are highest among Hazara (67\%) followed by Tajiks (62\%).

Thinking about the reasons the armed opposition used violence during the past year, would you say that you in general have a lot of sympathy, a little sympathy, or no sympathy at all for these armed opposition groups? (Q 45, Base 6467) BY ETHNICITY \& SETTLEMENT

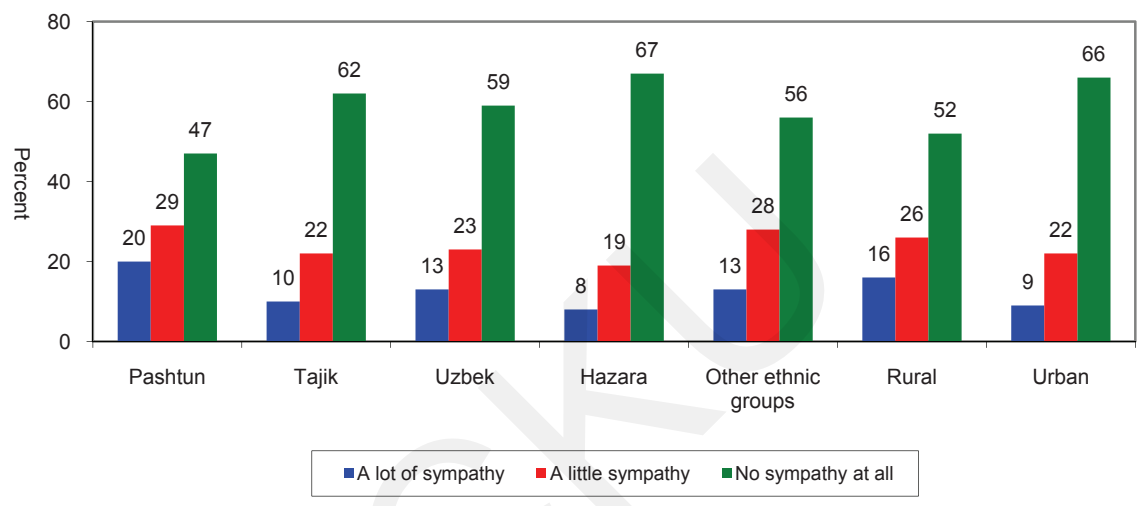

Fig. 4.8

Even though a majority of respondents nationally say they have no sympathy at all for the anti-government groups, this is not the case in all regions. At least half of respondents say they have some level of sympathy with armed opposition groups in the South West (52\%), South East (50\%) and West (50\%). This is also true for $43 \%$ in the East compared to around a third in the North West (33\%), North East (33\%) and Central/Kabul (34\%) regions and just 14\% in the Central/Hazarajat. However, sympathy with armed opposition groups has fallen in all regions since 2009. The decline has been most noticeable in the Central/Hazarajat (from $48 \%$ to $14 \%$ ), but is also notable in the North West (from 60\% to 33\%), East (from 65\% to 43\%), and South East (from 66\% to 50\%). 
Thinking about the reasons the armed opposition used violence during the past year, would you say that you in general have a lot of sympathy, a little sympathy, or no sympathy at all for these armed opposition groups? (Q-45) COMBINATION OF A LOT OF SYMPATHY AND LITTLE SYMPATHY RESPONSES, BY REGION, COMPARISON BETWEEN 2009 AND 2010

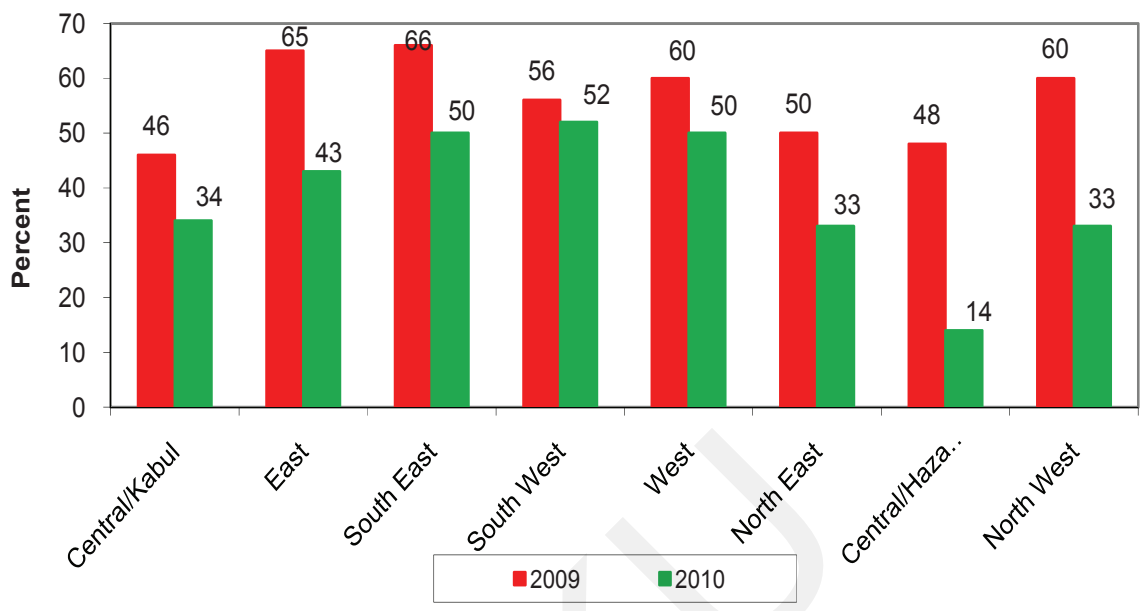

Fig. 4.9

Respondents who said they have a lot of sympathy for the armed opposition groups $(14 \%$ of all respondents) were asked to give their reasons. Around a quarter $(26 \%)$ say this is because the opposition groups are Afghans while a slightly smaller proportion $(23 \%)$ state it is because they are Muslims. Eighteen percent are unable or unwilling to give a reason for their support. Only $6 \%$ specifically mention that they support these groups because they are against the government.

You said that you have a lot of sympathy for the armed opposition groups. Why do you say that? (Q-45a, Base 933)

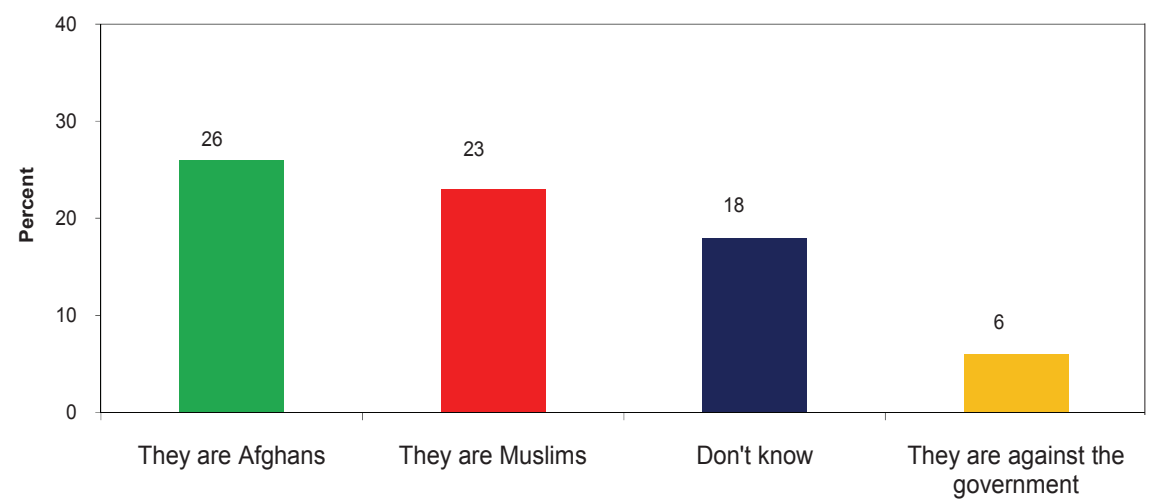

Fig. 4.10 
The reasons for sympathy vary among ethnic groups. More Pashtuns (31\%) say that it is due to the opposition groups being Afghans, while more Uzbeks (36\%) say it is because they are Muslims. Only $7 \%$ of Hazara respondents, who are predominantly Shia, say they have sympathy with armed opposition groups because they are Muslim. Hazara $(43 \%)$ and other ethnic groups $(38 \%)$ are the respondents who have some level of sympathy for armed opposition groups yet do not give a reason for their sympathy.

You said that you have a lot of sympathy for the armed opposition groups. Why do you say that? (Q 45a, Base 933) BY ETHNICITY

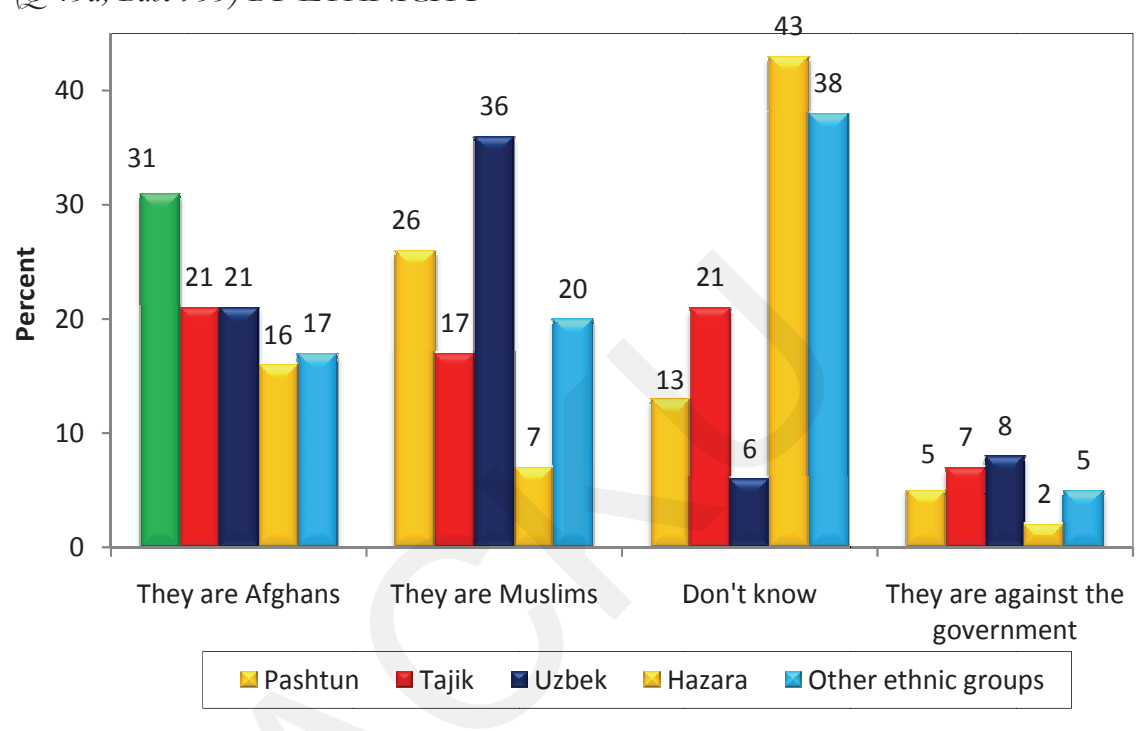

Fig. 4.11

The same question was asked to those respondents who said that they have a little sympathy with armed opposition groups (26\% of all respondents), and similar responses were recorded. Around a quarter (25\%) say this is because the armed groups are Afghans and another 20\% say it is because they are Muslims. Again one in five respondents is unable or unwilling to give a reason. Again, $6 \%$ specifically mention that their support is because the opposition groups are against the government. 
You said that you have a little sympathy for the armed opposition groups. Why do you say that? (Q-45b, Base 1651)

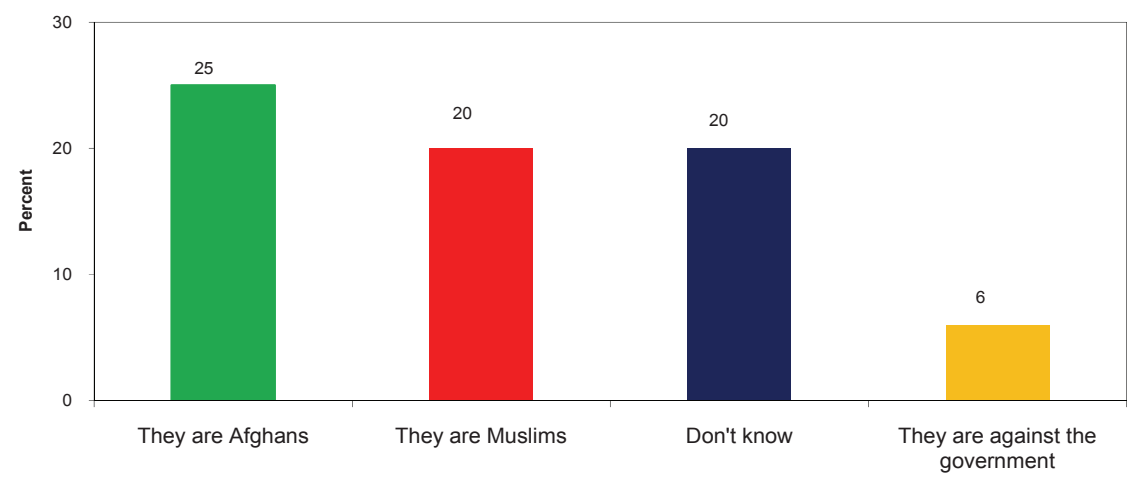

Fig. 4.12

Amongst respondents who have a little sympathy for armed opposition groups, the largest proportions across all ethnic groups say this is because the groups are Afghans. Amongst Uzbeks equal proportions of respondents say it is because the groups are Afghans and that they are Muslims. Very few Hazara (10\%) say they have a little sympathy with armed groups because they are Muslims, but a higher proportion of Hazara respondents $(11 \%)$ than any other group say this is because these groups are against the government $(11 \%)$.

You said that you have a little sympathy for the armed opposition groups. Why do you say that? $(Q$ 45b, Base 1651) BY ETHNICITY

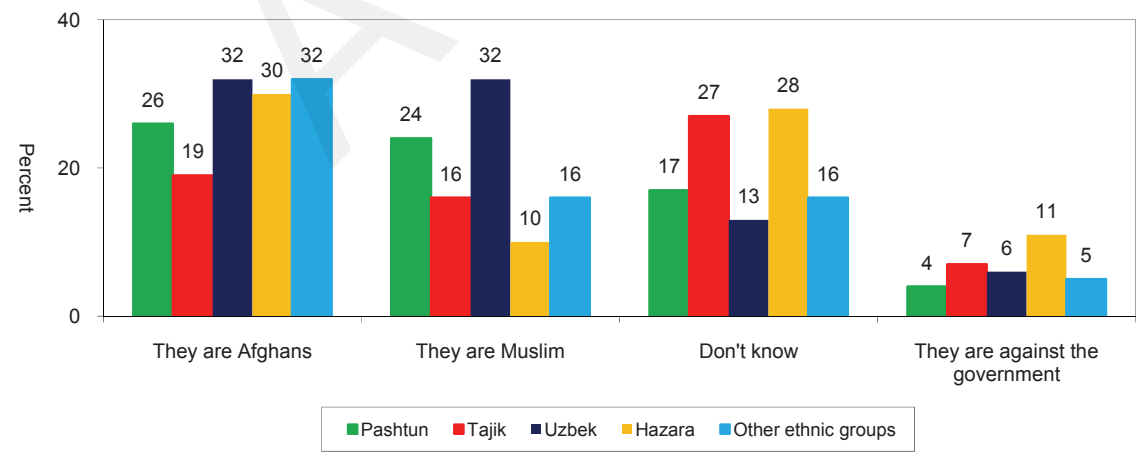

Fig. 4.13

In the same way, the survey asked those respondents who said they have no sympathy at all for the armed opposition groups (55\% of all respondents) to give their reasons. The most common reason, cited by approximately one in five respondents $(21 \%)$, is that the armed opposition groups are oppressors. Around one in seven say 
they have no sympathy for these groups because they do not want peace and security $(15 \%)$, they kill innocent people (15\%), and they are against the government $(14 \%)$. Again a significant proportion (18\%), do not give a definitive reason why they have no sympathy for the armed opposition groups.

You said that you have no sympathy for the armed opposition groups. Why do you say that? (Q-45c, Base 3584)

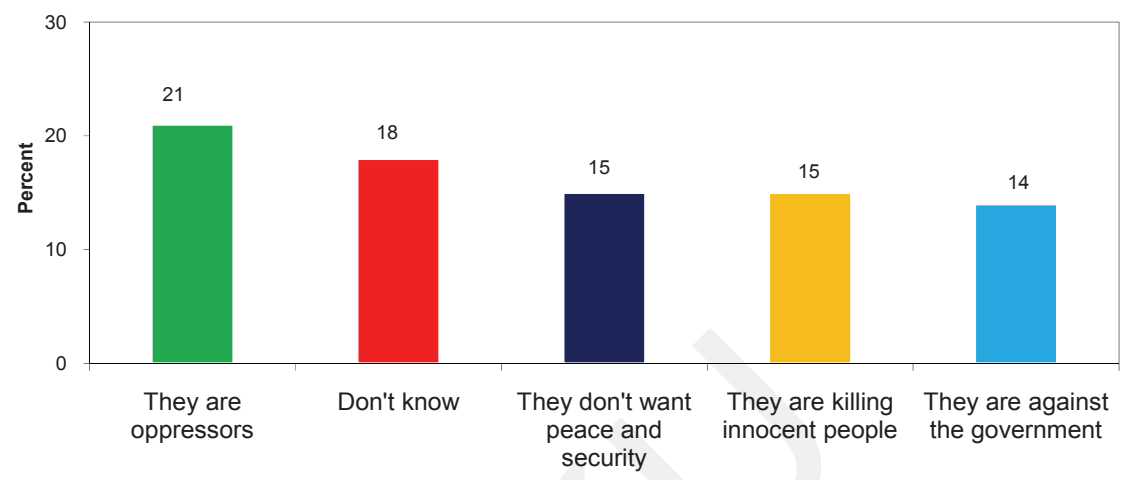

Fig. 4.14

Although, in general, the reasons given by men and women are similar, a quarter of women $(25 \%)$ say they have no sympathy for armed opposition groups because they are oppressors, compared to $17 \%$ of men.

Reasons for the lack of sympathy for armed opposition groups also vary between ethnic groups. Pashtuns most frequently say it is because these groups are killing innocent people $(18 \%)$. On the other hand, the most common reason given by Uzbek $(38 \%)$ and Tajik (21\%) respondents is that the armed opposition groups are oppressors. Among Hazara respondents no single reason dominates.

You said that you have no sympathy at all for the armed opposition groups. Why do you say that? (Q 45b, Base 3584) BY ETHNICITY

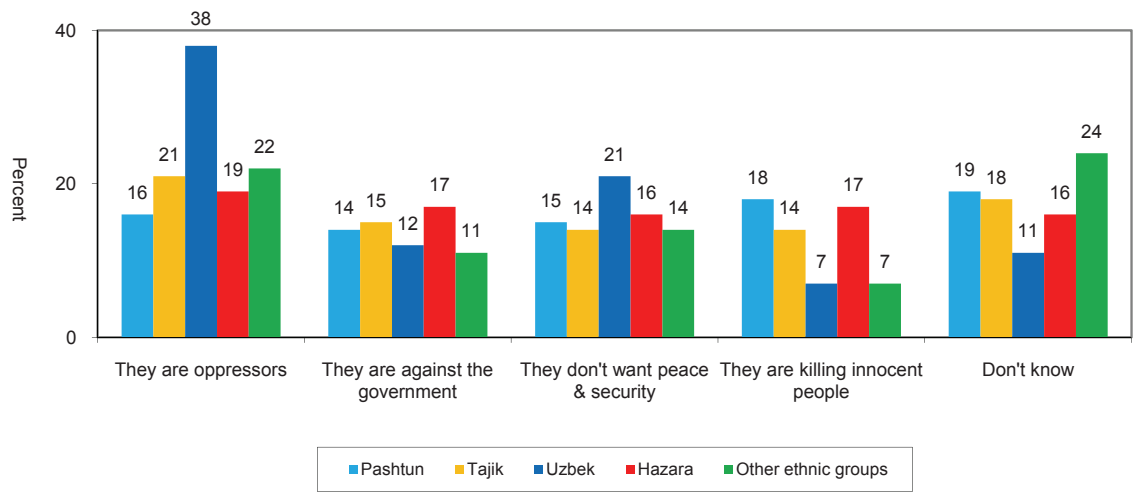

Fig. 4.15 
The perception of armed opposition groups as oppressors is strongest in the North West $(31 \%)$ and Central/Kabul (24\%) regions. The most common reason for the lack of sympathy for such groups amongst respondents in the South East (31\%) and South West $(25 \%)$ is that they kill innocent people. The most common reason given in the Central/Hazarajat region $(29 \%)$ is that these groups do not want peace and security. The largest group of respondents in North East (36\%), East (30\%) and West $(24 \%)$ are unable or unwilling to give a reason why they have no sympathy for armed opposition groups.

You said that you have no sympathy at all for the armed opposition groups. Why do you say that? (Q 45b, Base 3584) BY REGION

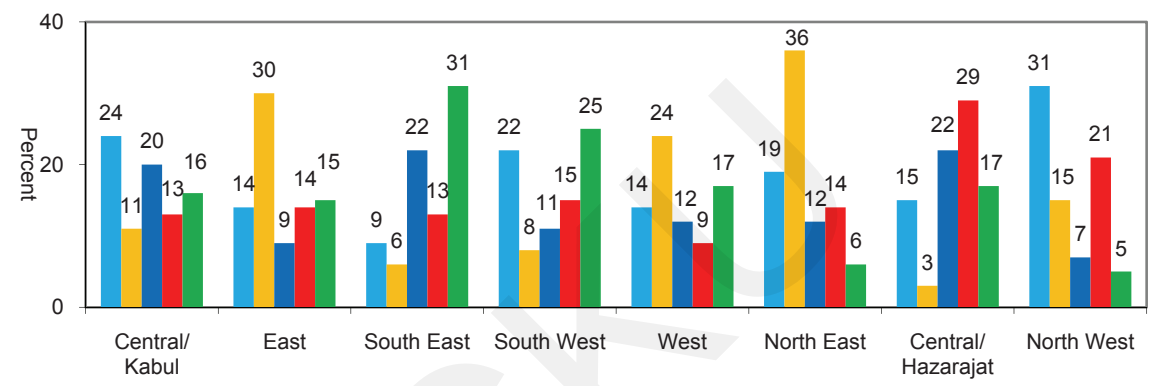

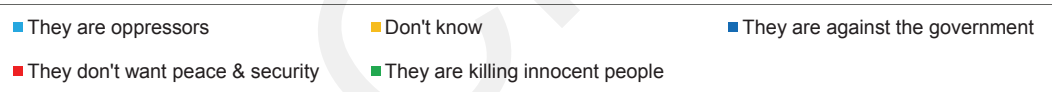

Fig. 4.16 


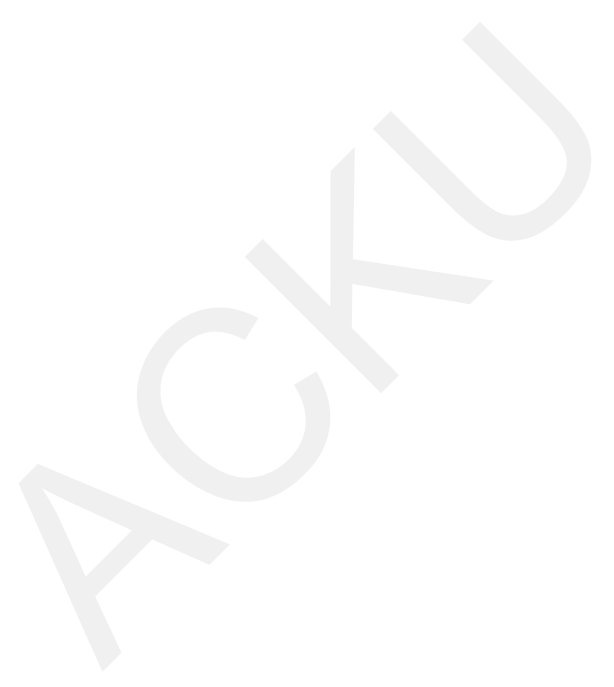




\section{Economy}

\subsection{Economic prosperity}

The survey attempted to find out how people perceive their level of economic prosperity. Respondents were asked to compare their current economic condition with their circumstances under the Taliban government (1996-2001). Forty-one percent of respondents report that their families are more prosperous today than they were under the Taliban regime. Around one-third (36\%) say that they are now less prosperous. Sixteen percent say that their level of economic prosperity is the same, while the remainder were absent during Taliban rule.

As has been the case in previous years, perceptions of current prosperity vis-à-vis that of the Taliban period shows a marked divergence of opinion across communities. Although the majority of Hazara (54\%,), Uzbek (53\%) and Tajik (51\%) respondents say their families are more prosperous today than under the Taliban regime, this is true for only $28 \%$ of Pashtun. Respondents who say their families are less prosperous today are mostly found in the East (43\%), South East (43\%) and South West $(42 \%)$, which are regions with a predominantly Pashtun population.

If you think about your family, would you say that today your family is more prosperous, less prosperous, or about as prosperous as under the Taliban government? (Q-13, Base 6467) BY ETHNICITY

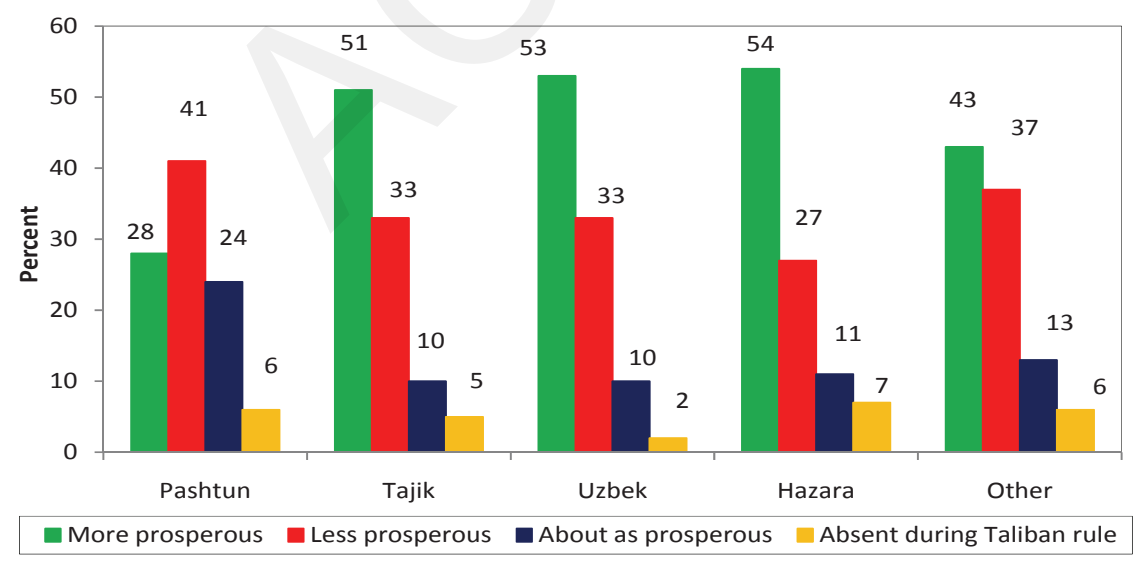

Fig 5.1

Interestingly the majority of respondents $(53 \%)$ in the lowest income group (those earning less than Afs.2000/month) say they are more prosperous now than during the Taliban period. But this is true for a much smaller proportion of respondents (39\%) from middle income groups (those earning between Afs.2000 and 10,000) 
and (40\%) high income groups (those earning over Afs.10,000). More respondents in urban $(48 \%)$ than rural $(40 \%)$ areas say their families are more prosperous today than during the Taliban period.

If you think about your family, would you say that today your family is more prosperous, less prosperous, or about as prosperous as under the Taliban government? (Q-13, Base 6467) BY INCOME AND SETTLEMENT

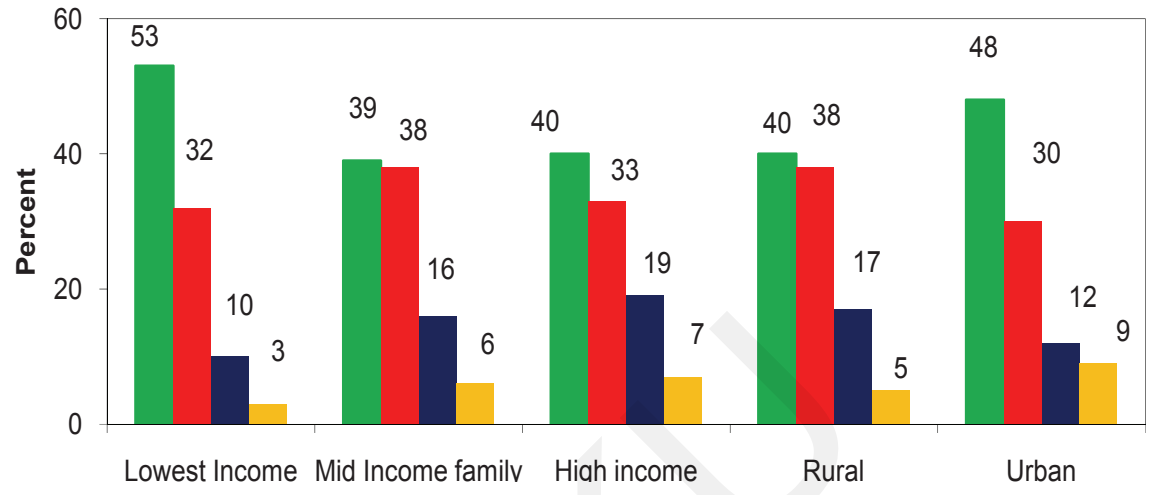

Fig 5.2

The proportion of respondents who say they are more prosperous now has declined in $2010(41 \%)$ compared to 2009 (54\%). The 2010 figure is amongst the lowest recorded since 2006 and is close to the figure recorded in 2008 (39\%) when Afghanistan was strongly affected by the global rise in food prices. Similarly, the proportion of respondents who say they are less prosperous now has risen to over a third $(36 \%)$, as it did in 2008 (36\%), compared to around a quarter in 2006 (26\%), 2007 (28\%) and 2009 (24\%).

Table 5.1: If you think about your family, would you say that today your family is more prosperous, less prosperous, or about as prosperous as under the Taliban government? (Q-13) COMPARI-

SON BETWEEN 2006, 2007, 2008, 2009 AND 2010

\begin{tabular}{|l|c|c|c|c|c|}
\hline & $\begin{array}{c}2006 \\
(\%)\end{array}$ & $\begin{array}{c}2007 \\
(\%)\end{array}$ & $\begin{array}{c}\mathbf{2 0 0 8} \\
\mathbf{( \% )}\end{array}$ & $\begin{array}{c}\mathbf{2 0 0 9} \\
\mathbf{( \% )}\end{array}$ & $\begin{array}{c}\mathbf{2 0 1 0} \\
\mathbf{( \% )}\end{array}$ \\
\hline More prosperous & 54 & 49 & 39 & 54 & 41 \\
\hline Less prosperous & 26 & 28 & 36 & 24 & 36 \\
\hline About as prosperous & 12 & 14 & 16 & 14 & 16 \\
\hline Absent during Taliban rule & 7 & 8 & 7 & 6 & 5 \\
\hline
\end{tabular}

Many factors could lead to this perception, including the inability of the state or the market to generate employment. This is consistent with the finding that the majority of respondents $(56 \%)$ rate the government's performance in reviving/developing the economy to be quite bad or very bad, and two-thirds (67\%) saying the same 
regarding the creation of job opportunities (see Chapter 7, 7.3 Satisfaction with government performance). In addition, unemployment has consistently been identified as one of the biggest problems at both national and local levels (see Chapter 2, 2.4 - Afghanistan's biggest problem: National level and 2.5 Afghanistan's biggest problem: Local level).

\subsection{Household situation over the last year}

The survey also endeavored to measure the economic situation of Afghan households in greater detail by comparing the situation of households today with their situation one year ago in terms of financial and physical well-being, as well as access to basic services and amenities. The proportion of respondents who report improvements in their situation during the last year is summarized in the following table.

Table 5.2: Percentage of people whose situation has gotten better, remained the same or gotten worse compared to one year ago in various domains (Q-14a-h, Base 6467)

\begin{tabular}{|l|c|c|c|} 
& $\begin{array}{c}\text { Better } \\
(\mathbf{\%})\end{array}$ & $\begin{array}{c}\text { The same } \\
(\mathbf{\%})\end{array}$ & $\begin{array}{c}\text { Worse } \\
(\mathbf{\%})\end{array}$ \\
\hline a) Financial well-being of your household & 42 & 49 & 9 \\
\hline b) Employment opportunities & 17 & 44 & 38 \\
\hline c) Availability of products in the market & 27 & 49 & 22 \\
\hline d) Quality of your food diet & 33 & 50 & 16 \\
\hline e) Physical conditions of your house/dwelling & 25 & 54 & 20 \\
\hline f) Health well-being of your family members & 35 & 46 & 18 \\
\hline g) Electric supply & 23 & 36 & 40 \\
\hline h) Access to schools & 42 & 42 & 15 \\
\hline
\end{tabular}

Overall, respondents identify the greatest improvements in the financial well-being of their household and access to schools, which $42 \%$ of respondents say are now better than a year ago. However the benefits of increased financial well-being are not evenly shared. While nearly half of those who earn over Afs.10,000 per month (48\%) report an improvement in their financial well-being in the past year, this is true for only around a third of respondents (35\%) who earn less than Afs.2,000 per month.

The high percentage of respondents who say their access to schools is better than last year $(42 \%)$ corroborates the high levels of satisfaction regarding the availability of education for children ( $68 \%$ of respondents say this is quite good or very good in their local area - see Chapter 6, 6.2: Facilities available in local area). It is also consistent with the finding that the majority of respondents $(54 \%)$ are aware of development programs regarding education (see Chapter 6, 6.3: Knowledge of development programs).

Around a third of respondents report improvements in the health of family mem- 
bers $(35 \%)$ and in the quality of their food diet (33\%). Around a quarter identify Improvement in the availability of products in the market $(27 \%)$, the physical conditions of their house (25\%) and electricity supply (23\%). Respondents report the least improvement in employment opportunities (17\%). Again this is consistent with the identification of unemployment as one of the biggest problems at both national and local levels (see Chapter 2, 2.4 - Afghanistan's biggest problem: National level and 2.5 Afghanistan's biggest problem: Local level).

Although 23\% of respondents reported that their electricity supply has improved compared to last year, there is a big difference between those who live in rural and urban areas. Only $15 \%$ of rural respondents think that the supply of electricity has improved, while $52 \%$ of respondents living in urban areas say this. Central/Kabul is the only region in which the largest group of respondents report that the electricity supply has improved during the past year (46\% compared to the national average of $23 \%$ ).

Only $17 \%$ of respondents say that employment opportunities have improved compared to last year. Not surprisingly, this perception is also correlated with income. Whereas 13\% of those who earn less than Afs. 2000 per month report that employment opportunities have gotten better in the past year, $23 \%$ of those who earn above Afs.10,000 report the same.

These findings are consistent with respondents' views on local services and amenities which show the lowest levels of satisfaction for the availability of jobs and the supply of electricity (see Chapter 6, 6.2: Facilities available in local area).

Across all areas except electricity supply, more people report improvements in the last year in 2010 than in 2009. The greatest increases are amongst respondents reporting an improvement in the financial well-being of their household (42\% in 2010 compared to $31 \%$ in 2009), quality of food diet (33\% in 2010 compared to $23 \%$ in $2009)$ and availability of products in the market (27\% in 2010 compared to $19 \%$ in 2009). However, the proportion of respondents reporting an improvement in the electricity supply has remained stable (23\% in 2009 and 2010).

Table 5.3: Percentage of people whose situation has gotten better compared to one year ago in various domains (Q-14a-h) COMPARISON BETWEEN 2009 AND 2010

\begin{tabular}{|l|c|c|} 
& $\mathbf{2 0 0 9}$ & $\mathbf{2 0 1 0}$ \\
$\mathbf{( \% )}$ & 31 & 42 \\
\hline Financial well-being of your household & 40 & 42 \\
\hline Access to schools & 32 & 35 \\
\hline Health well-being of your family members & 23 & 33 \\
\hline Quality of your food diet & 19 & 27 \\
\hline Availability of products in the market & 20 & 25 \\
\hline Physical conditions of your house/dwelling & 23 & 23 \\
\hline Electric supply & 11 & 17 \\
\hline Employment opportunities & & \\
\hline
\end{tabular}




\section{Development and Service Delivery}

\subsection{Services and Facilities available in local areas}

The survey measures perceptions of the current condition of basic infrastructure and essential public services that citizens can access in their local area. The table below summarizes respondents' views on a range of basic facilities available in the villages and neighborhoods where they live.

Table 6.1: Present condition of basic facilities in localities (Q-10a-i, Base 6467)

\begin{tabular}{|l|c|c|c|c|} 
& $\begin{array}{c}\text { Very } \\
\text { good } \\
\mathbf{( \% )}\end{array}$ & $\begin{array}{c}\text { Quite } \\
\text { good } \\
\mathbf{( \% )}\end{array}$ & $\begin{array}{c}\text { Quite } \\
\text { Bad } \\
\mathbf{( \% )}\end{array}$ & $\begin{array}{c}\text { Very } \\
\text { Bad } \\
(\mathbf{\%})\end{array}$ \\
\hline a) The availability of clean drinking water & 23 & 40 & 25 & 12 \\
\hline b) The availability of water for irrigation & 14 & 35 & 31 & 16 \\
\hline c) The availability of jobs & 5 & 22 & 38 & 34 \\
\hline d) The supply of electricity & 15 & 19 & 25 & 41 \\
\hline e) The security situation & 26 & 39 & 20 & 13 \\
\hline f) The availability of clinics and hospitals & 10 & 36 & 36 & 17 \\
\hline g) The availability of medicine & 10 & 33 & 38 & 17 \\
\hline h) The availability of education for children & 23 & 45 & 22 & 10 \\
\hline $\begin{array}{l}\text { i) Your freedom of movement - the ability } \\
\text { to move safely in your area or district }\end{array}$ & 24 & 39 & 24 & 12 \\
\hline
\end{tabular}

Overall, respondents report the highest level of satisfaction regarding the availability of education for children, with $68 \%$ saying this is quite good or very good in their local area. A similarly high proportion (65\%) judge the local security situation to be quite good or very good, while $63 \%$ say the same about the availability of clean drinking water, and the ability to move safely in their area or district.

On the other hand, people are least satisfied with the availability of jobs. Nearly three quarters $(72 \%)$ of respondents say the availability of jobs in their local area is quite bad or very bad. Two thirds $(66 \%)$ say the same about the supply of electricity.

There are significant regional variations in satisfaction with public services and infrastructure. Although more than three quarters (77\%) of respondents in the Central/ Kabul region say the availability of education for children is good or very good, this falls to a little over a third (39\%) in the South West. This may reflect the difficulties faced by the Ministry of Education, which reports that in 2010 it has only 
been able to open 220 of the 673 schools which were closed in 2009, mostly in the South West ${ }^{1}$. Similarly in the South West, the lowest proportion of respondents in any region say they are aware of development projects regarding the reconstruction/ opening of schools (38\%) (see below 6.3 Awareness of development programs) and only $8 \%$ of respondents mention the opening of schools for girls as the reason why the country is going in the right direction (see chapter 2, 2.2 Reasons for optimism, Table 2.1).

Over three quarters of respondents in the East (78\%) and South East (76\%) say the availability of clean drinking water is very good or quite good, but this is true for less than half of respondents in the Central/Hazarajat (39\%), North West (41\%) and North East (48\%) regions. Conversely, while the majority of respondents in the Central/Hazarajat (62\%) and East (61\%) say the availability of water for irrigation is very good or quite good; this is true for only $37 \%$ in the North West, $46 \%$ in the West and $49 \%$ in the South East.

Forty-six percent of respondents nationally say the availability of clinics and hospitals is very good or quite good, and $43 \%$ say the same about the availability of medicine. Satisfaction is highest in the Central/Kabul region where the majority is positive regarding the availability of medical services (55\%) and medicines (56\%). In the Central/Hazarajat only $21 \%$ of respondents are satisfied with the availability of hospitals and clinics and the availability of medicines. This region also records the lowest proportion of respondents who say they are aware of development projects related to healthcare being implemented in their local area (see below 3.3 Awareness of development programs) and healthcare is ranked as the top development priority in the Central/Hazarajat region (see following section 6.2, Critical needs)

Overall, nearly two-thirds $(65 \%)$ of respondents rated security in their local area as good or very good. While over four-fifths of respondents say this in the North West (84\%) and Central/Hazarajat (83\%) regions, only 36\% in the South West and 42\% in the South East say the same. Similarly, although 63\% of respondents judge their ability to move safely in their local area to be good or very good, this also varies from region to region. The highest proportions of respondents who say they can move safely in their area or district are recorded in the North West (80\%), Central/Hazarajat (75\%), Central/Kabul (73\%) and North East (72\%) compared to only 38\% in the South West, and around half in the South East (50\%), West (51\%) and East (55\%). 
When asked about their local electricity supply, only around one-third (34\%) of respondents nationally give a positive assessment. The majority of respondents in the Central/Kabul region (55\%) say this is good or very good and over a third say the same in the West (35\%) and North East (34\%) but this is true for only one in five in the East $(21 \%)$ and one in eight in the South East (12\%). A much higher proportion of respondents in urban $(70 \%)$ than rural $(23 \%)$ areas give a positive assessment of the electricity supply in their locality.

Only around a quarter of respondents $(27 \%)$ give a positive assessment of the availability of jobs in their local area, with the highest proportions who think the availability of jobs is good or very good in the East (34\%) and West (34\%).

Table 6.2: How would you rate availability of basic facilities? (Q-10a-i, Base 6467) BY REGION

\begin{tabular}{|c|c|c|c|c|c|c|c|c|}
\hline \multirow{2}{*}{$\begin{array}{l}\text { Base: Those saying very } \\
\text { good and quite good }\end{array}$} & Central/ & East & South & South & \multicolumn{2}{|c|}{ West North } & \multirow{2}{*}{$\begin{array}{c}\text { Central/ } \\
\text { Hazarajat } \\
(\%)\end{array}$} & \multirow{2}{*}{$\begin{array}{c}\text { North } \\
\text { West } \\
(\%)\end{array}$} \\
\hline & $\begin{array}{c}\text { Kabul } \\
(\%)\end{array}$ & $(\%)$ & $\begin{array}{l}\text { East } \\
(\%)\end{array}$ & $\begin{array}{l}\text { West } \\
(\%)\end{array}$ & $(\%)$ & $\begin{array}{c}\text { East } \\
(\%)\end{array}$ & & \\
\hline $\begin{array}{l}\text { a) The availability of clean } \\
\text { drinking water }\end{array}$ & 72 & 78 & 76 & 71 & 63 & 48 & 39 & 41 \\
\hline $\begin{array}{l}\text { b) The availability of water } \\
\text { for irrigation }\end{array}$ & 51 & 61 & 49 & 51 & 46 & 55 & 62 & 37 \\
\hline c) The availability of jobs & 25 & 34 & 20 & 33 & 34 & 26 & 12 & 22 \\
\hline d) The supply of electricity & 55 & 21 & 12 & 30 & 35 & 34 & 30 & 25 \\
\hline e) The security situation & 79 & 54 & 42 & 36 & 61 & 73 & 83 & 84 \\
\hline $\begin{array}{l}\text { f) The availability of clinics } \\
\text { and hospitals }\end{array}$ & 55 & 53 & 44 & 35 & 51 & 44 & 21 & 42 \\
\hline $\begin{array}{l}\text { g) The availability of } \\
\text { medicine }\end{array}$ & 56 & 51 & 42 & 31 & 52 & 32 & 21 & 37 \\
\hline $\begin{array}{l}\text { h) The availability of } \\
\text { education for children }\end{array}$ & 77 & 72 & 68 & 39 & 62 & 74 & 68 & 72 \\
\hline $\begin{array}{l}\text { i) Your freedom of movement } \\
\text { - the ability to move safely in } \\
\text { your area or district }\end{array}$ & 73 & 55 & 50 & 38 & 51 & 72 & 75 & 80 \\
\hline
\end{tabular}

Overall assessments of the availability of most basic facilities and public services have not registered significant improvement over time. The availability of education for children has consistently remained the basic amenity with which communities are most satisfied. Approximately two-thirds of respondents have judged the availability of education for children to be good or very good since 2007 (72\% in 2007, 70\% in 2008, 67\% in 2009 and 68\% in 2010). Satisfaction with the availability of clear drinking water has also remained stable with around $62 \%$ of respondents rating this positively. 
Although people remain least satisfied with the availability of jobs, satisfaction has been rising slightly since 2008 (from 21\% who said this is good or very good in 2008 to $24 \%$ in 2009 and $27 \%$ in 2010). However, these figures all remain below the level of satisfaction recorded in 2007 (30\%). Satisfaction with the supply of electricity has also been rising slightly, from $25 \%$ in 2008 , to $34 \%$ who judged this to be good or very good in 2009 and 2010. This result suggests that some small progress is being made even in the areas where respondents are least satisfied with service delivery overall.

On the other hand, satisfaction has been falling consistently since 2007 with regard to health services such as the availability of clinics and hospitals (from 56\% in 2007 to $51 \%$ in $2008,49 \%$ in 2009 and $46 \%$ in 2010), and the availability of medicines (from $49 \%$ in 2008 to $44 \%$ in 2009 , and $43 \%$ in 2010 ).

Table 6.3: Present condition of basic facilities in localities (Q-10a-i) combination of quite good and very good responses COMPARISON BETWEEN 2007, 2008, 2009 AND 2010

\begin{tabular}{l|c|c|c|c|}
\multicolumn{1}{c|}{ Development issues } & $\begin{array}{c}\mathbf{2 0 0 7} \\
\mathbf{( \% )}\end{array}$ & $\begin{array}{c}\mathbf{2 0 0 8} \\
\mathbf{( \% )}\end{array}$ & $\begin{array}{c}\mathbf{2 0 0 9} \\
\mathbf{( \% )}\end{array}$ & $\begin{array}{c}\mathbf{2 0 1 0} \\
\mathbf{( \% )}\end{array}$ \\
\hline $\begin{array}{l}\text { a) The availability of clean drinking water } \\
\text { b) The availability of water for irrigation }\end{array}$ & $\mathbf{6 3}$ & 62 & 63 & 63 \\
\hline c) The availability of jobs & 30 & 47 & 53 & 49 \\
\hline d) The supply of electricity & 31 & 25 & 34 & 27 \\
\hline e) The security situation & 66 & 62 & 64 & 65 \\
\hline f) The availability of clinics and hospitals & 56 & 51 & 49 & 46 \\
\hline g) The availability of medicine & - & 49 & 44 & 43 \\
\hline h) The availability of education for children & 72 & 70 & 67 & 68 \\
\hline i) Your freedom of movement - the ability & - & - & - & 63 \\
to move safely in your area or district & & & & \\
\hline
\end{tabular}

\subsection{Critical needs}

The survey examined how people prioritize development needs, particularly in terms of basic infrastructure such as roads, power, water, healthcare and education. Respondents were asked to rank these issues in order of priority: from 1 - most important to 5 - least important.

Survey results show that nationally roads are ranked as first priority, with power in second place, followed by water, healthcare and education. This is consistent with the low levels of satisfaction with the availability of electricity reported by respondents (see previous section - 6.1 Services and Facilities available in local areas). However, the difference in priority accorded to these five issues is not substantial. The priority order in 2010 is the same as in 2009. 
Table 6.4: Importance of development issues in rank order (Q-9a-e) COMPARISON BETWEEN 2007, 2008, 2009 AND 2010

\begin{tabular}{|l|c|c|c|c|}
$\begin{array}{r}\text { Development issues } \\
\text { Ranking }\end{array}$ & $\begin{array}{c}\mathbf{2 0 0 7} \\
\mathbf{( \% )}\end{array}$ & $\begin{array}{c}\mathbf{2 0 0 8} \\
\mathbf{( \% )}\end{array}$ & $\begin{array}{c}\mathbf{2 0 0 9} \\
\mathbf{( \% )}\end{array}$ & $\begin{array}{c}\mathbf{2 0 1 0} \\
\mathbf{( \% )}\end{array}$ \\
\hline Importance of roads & 1 & 3 & 1 & 1 \\
\hline Importance of power & 3 & 1 & 2 & 2 \\
\hline Importance of water & 2 & 2 & 3 & 3 \\
\hline Importance of healthcare & 5 & 4 & 4 & 4 \\
\hline Importance of education & 4 & 5 & 5 & 5 \\
\hline
\end{tabular}

The highest priority for those living in rural areas is power, followed by roads. This corroborates the much lower levels of satisfaction with electricity supply in rural areas (see previous section - 6.1 Services and Facilities available in local areas). For those living in urban areas, roads are the top-ranked development priority, followed by water.

Development priorities also vary between regions. Roads emerge as the top priority for inhabitants of the Central/Kabul, South West and North East regions, while those living in the East, West and North West accord the highest priority to power supply.

The top priority for people in the South East is water supply which is clearly related to the low levels of satisfaction with the availability of water for irrigation recorded in this region (see previous section 6.1 Services and Facilities available in local areas, table 3.2). In the Central/Hazarajat healthcare emerges as the top priority, reflecting the low levels of satisfaction with access to healthcare facilities and medicine in the region (see previous section 6.1 Services and Facilities available in local areas, table 6.2).

Table 6.5: Importance of development issues in rank order (Q-9a-e, Base 6467) BY REGION

\begin{tabular}{|l|c|c|c|c|c|c|c|c|}
$\begin{array}{c}\text { Development Issues } \\
\text { Ranked }\end{array}$ & $\begin{array}{c}\text { Central/ } \\
\text { Kabul }\end{array}$ & East & $\begin{array}{c}\text { South } \\
\text { East }\end{array}$ & $\begin{array}{c}\text { South } \\
\text { West }\end{array}$ & $\begin{array}{c}\text { West } \\
\text { North }\end{array}$ & $\begin{array}{c}\text { Central/ } \\
\text { East }\end{array}$ & $\begin{array}{c}\text { North } \\
\text { Hazarajat }\end{array}$ & \begin{tabular}{c} 
West \\
\hline Importance of roads
\end{tabular} \\
\hline Importance of power & 5 & 3 & 2 & 1 & 2 & 1 & 2 & 3 \\
\hline Importance of water & 3 & 2 & 1 & 3 & 3 & 3 & 4 & 2 \\
\hline Importance of healthcare & 4 & 4 & 3 & 5 & 5 & 5 & 1 & 4 \\
\hline Importance of education & 2 & 5 & 5 & 4 & 4 & 4 & 3 & 5 \\
\hline
\end{tabular}

\subsection{Awareness of development programs}

International development agencies have been supporting a wide variety of projects and programs in Afghanistan. The survey sought to gauge whether respondents are aware of any project or program in their local area. All respondents were asked 
whether they knew of, or had heard of, any project or program implemented with foreign aid in their area or district in the last 12 months. Respondents were then given a list of the kinds of development programs that might be present in their area.

More than half (54\%) of respondents say they are aware of projects relating to reconstruction/building of roads and bridges, and education including reconstruction/ opening of schools, training teachers etc. Projects related to drinking water supply are mentioned by $43 \%$ of respondents and healthcare programs, such as primary health centers and regular visits of doctors are mentioned by $39 \%$. However, only $28 \%$ of respondents report being aware of development programs relating to electricity supply which has been amongst the highest-ranking development priorities for Afghans since 2008 (see Table 6.1: Importance of development issues in rank order).

Table 6.6: Percentage of respondents who know or have heard of any development project or program implemented with foreign aid in their localities (Q-11 Aa-l, Base 6467)

\begin{tabular}{|c|c|c|c|c|c|c|c|c|c|}
\hline & $\begin{array}{l}\text { All } \\
(\%)\end{array}$ & $\begin{array}{c}\text { Central } \\
\text { /Kabul } \\
(\%)\end{array}$ & $\begin{array}{l}\text { East } \\
(\%)\end{array}$ & $\begin{array}{c}\text { South } \\
\text { East } \\
(\%)\end{array}$ & $\begin{array}{c}\text { South } \\
\text { West } \\
(\%)\end{array}$ & $\begin{array}{l}\text { West } \\
(\%)\end{array}$ & $\begin{array}{c}\text { North } \\
\text { East } \\
(\%)\end{array}$ & $\begin{array}{c}\text { Central/ } \\
\text { Hazarajat } \\
(\%)\end{array}$ & $\begin{array}{l}\text { North } \\
\text { Wes } \\
(\%)\end{array}$ \\
\hline $\begin{array}{l}\text { Reconstruction/ building } \\
\text { of roads, bridges }\end{array}$ & 54 & 53 & 70 & 58 & 56 & 47 & 51 & 43 & 52 \\
\hline $\begin{array}{l}\text { Education (reconstruction/ } \\
\text { opening of school, more } \\
\text { teachers etc.) }\end{array}$ & 54 & 55 & 63 & 63 & 38 & 50 & 66 & 40 & 48 \\
\hline Water supply for drinking & 43 & 41 & 58 & 56 & 55 & 40 & 42 & 9 & 29 \\
\hline $\begin{array}{l}\text { Healthcare (primary health } \\
\text { centre, regular visits of } \\
\text { doctors, etc.) }\end{array}$ & 39 & 37 & 42 & 45 & 40 & 38 & 47 & 19 & 30 \\
\hline De-mining & 30 & 30 & 39 & 25 & 31 & 32 & 34 & 4 & 25 \\
\hline $\begin{array}{l}\text { Demilitarization/disarma- } \\
\text { ment }\end{array}$ & 28 & 26 & 32 & 23 & 20 & 29 & 34 & 17 & 31 \\
\hline Electricity supply & 28 & 47 & 16 & 11 & 25 & 25 & 33 & 22 & 18 \\
\hline Building new mosques & 28 & 32 & 29 & 27 & 35 & 30 & 31 & 11 & 16 \\
\hline Water supply for irrigation & 27 & 25 & 33 & 27 & 42 & 23 & 34 & 10 & 17 \\
\hline $\begin{array}{l}\text { Reconstruction/programs } \\
\text { in agriculture }\end{array}$ & 26 & 22 & 34 & 28 & 34 & 29 & 28 & 12 & 17 \\
\hline $\begin{array}{l}\text { Humanitarian programs - } \\
\text { help in food, medicines, shel- } \\
\text { ter, production materials etc. }\end{array}$ & 23 & 19 & 23 & 25 & 26 & 32 & 21 & 12 & 20 \\
\hline $\begin{array}{l}\text { Reconstruction/programs } \\
\text { in industry }\end{array}$ & 15 & 14 & 21 & 14 & 17 & 18 & 18 & 4 & 9 \\
\hline
\end{tabular}

As the table above indicates, awareness of development projects also varies between regions. While $70 \%$ of respondents in the East say they are aware of road building and reconstruction projects, this is true for less than half of respondents in the 
Central/Hazarajat (43\%) and West (47\%). Similarly, while around two thirds of respondents say they are aware of education related projects in the North East $(66 \%)$, South East (63\%) and East (63\%), this is true for just over one-third of respondents in the South West (38\%) and less than half in the Central/Hazarajat (40\%) and North West (48\%). A similar pattern emerges with respect to healthcare projects. While at least $40 \%$ of respondents are aware of such projects in the North East (47\%), South East (45\%), East (42\%) and South West (40\%), this is true for only $19 \%$ of respondents in the Central/Hazarajat region.

More than half of respondents in the East (58\%), South East (56\%), and South West $(55 \%)$ are aware of projects to improve the supply of drinking water, but less than one in three respondents are aware of these in the North West (29\%) and less than one in ten in the Central/Hazarajat (9\%) regions. Projects targeting water supply for irrigation are again most frequently cited in the South West (42\%), North East (33\%) and East $(32 \%)$ and again by the lowest proportions in the Central/Hazarajat $(10 \%)$ and North West (17\%) regions.

Awareness of the building of mosques with foreign aid is mentioned by around a third of respondents (between 27\% and 35\%) in all regions except the Central/ Hazarajat (11\%) and North West (16\%) regions.

The overall pattern that emerges suggests a heavy concentration of donor-assisted development projects focusing on basic infrastructure and public services in certain areas of the country, particularly the East, with other regions, especially the Central/ Hazarajat and to a lesser extent the North West, less aware of any development assistance in the region. This could be due, in part, to donor strategies designed to link development initiatives with security-related initiatives. Indeed, awareness of security-related projects such as de-mining and demilitarization/disarmament are also highest in the East (39\% de-mining, 32\% demilitarization) and the North East (34\% for each).

This pattern varies to some degree in relation to projects targeting the improvement of electricity supply. While almost half of respondents are aware of such projects in the Central/Kabul (47\%) region and a third in the North East (33\%), this is true for only $11 \%$ in the South East and 16\% in the East. However, the North West (18\%) and the Central/Hazarajat (22\%) regions fare poorly in this area, as well.

Responses in 2010 are broadly similar to those recorded in previous years. Respondents' awareness of road reconstruction and education programs has topped the list for five consecutive years. 
In order to measure public perceptions regarding who is primarily responsible for providing aid for development projects, respondents were asked whether they thought the Afghan government, foreign sponsors or both were responsible for these activities in various sectors. The majority of respondents say the Afghan government is the primary agency responsible for projects to support building mosques (66\%), improving the supply of electricity $(58 \%)$, education $(55 \%)$ and the supply of water for irrigation (50\%). The Afghan government is also seen to be the lead agency for projects to improve the drinking water supply (46\%), demilitarization and disarmament $(46 \%)$, healthcare $(45 \%)$ and reconstruction or building of roads and bridges (38\%). On the other hand, a slightly higher proportion of respondents think foreign donors are mainly responsible for de-mining $(39 \%)$ and humanitarian programs (34\%).

Table 6.7: Has the Afghan government or foreign sponsors been primarily responsible for providing most of the aid for the projects? (Q-11Ba-l, Base 6467)

\begin{tabular}{|l|c|c|c|} 
& $\begin{array}{c}\text { Afghan } \\
\text { Govt. } \\
\mathbf{( \% )}\end{array}$ & $\begin{array}{c}\text { Foreign } \\
\text { Sponsor } \\
\mathbf{( \% )}\end{array}$ & Both \\
\hline a) Reconstruction/ building of roads, bridges & 38 & 33 & 24 \\
\hline b) Water supply for drinking & 46 & 30 & 19 \\
\hline c) Water supply for irrigation & 50 & 24 & 20 \\
\hline d) Electricity supply & 58 & 18 & 17 \\
\hline $\begin{array}{l}\text { e) Healthcare (primary health center, regular } \\
\text { visits of doctors, etc.) }\end{array}$ & 45 & 24 & 25 \\
\hline $\begin{array}{l}\text { f) Education (reconstruction/opening of } \\
\text { school, more teachers etc.) }\end{array}$ & 55 & 17 & 22 \\
\hline g) Demining & 32 & 39 & 24 \\
\hline h) Demilitarization/disarmament & 46 & 24 & 23 \\
\hline i) Reconstruction/programs in agriculture & 44 & 25 & 24 \\
\hline j) Reconstruction/programs in industry & 42 & 31 & 21 \\
\hline k) Building new mosques & 66 & 14 & 11 \\
\hline $\begin{array}{l}\text { l) Humanitarian programs - help in food, } \\
\text { medicines, shelter, production materials etc. }\end{array}$ & 32 & 34 & 26 \\
\hline
\end{tabular}




\section{Government}

\subsection{Confidence in public institutions}

People's confidence in public institutions is a measure of public trust in government and other important governance institutions. Survey respondents were asked about the confidence they have in a range of public institutions and organizations. A list was read out and respondents were asked to state how much confidence they have in each institution to perform its job. The survey reveals that the highest levels of public confidence are still enjoyed by the Afghan National Army (ANA), with $91 \%$ of respondents saying they have a fair amount or a great deal of confidence in this body, as was the case in 2009. The second-highest level of confidence is again recorded for the Afghan National Police (ANP), with $79 \%$ of respondents expressing some level of confidence in them. However, this is lower than 2009 (84\%).

These findings are consistent with the fact that a significant majority of respondents think the ANA (86\%) and the ANP (77\%) help improve security, and believe the ANP is efficient at arresting those who have committed crimes so that they can be brought to justice (70\%) (see Chapter 3, 3.5: Perceptions of the ANP, and 3.6: Perceptions of the ANA). They are also consistent with the relatively high levels of satisfaction with the performance of government in providing security (62\%), as the ANA and the ANP comprise the largest and most visible government security services (see below, 7.3 Satisfaction with central government performance in policy and service delivery). The higher level of confidence expressed in the ANA is also consistent with lower level of corruption encountered in this organization compared to the ANP (see Chapter 8, 8.2 Payment of bribes). Since 2006, these two institutions have consistently secured the highest levels of public confidence. However, public confidence in the ANP has slightly declined over this period, from $86 \%$ in 2006 to $79 \%$ in 2010 .

Public confidence in electronic media such as radio and television is also high (71\%). However, here too confidence levels have been falling since 2006 when the figure was $84 \%$. Just over half $(57 \%)$ of respondents say they have confidence in newspapers and print media, but this figure is also lower than in previous years when it was around $62 \%$.

In 2010, a small majority of respondents report some level of confidence in both national (55\%) and international (54\%) non-governmental organizations (NGOs). However, this represents a significant fall in confidence from previous years. Between 2007 and 2009, confidence in national NGOs was stable at around 60\%, and confidence in international NGOs at around $65 \%$. This fall in confidence in NGOs over the last year may be influenced by recent changes in the Law on Non Governmental Organisations which prohibit NGOs from engaging in various kinds of proj- 
ects and service delivery that they have been involved in the past, which means that the work they carry out may be less visible to the public. In addition, this low level of confidence corresponds with the perception that both NGOs and the donors who fund them more often make decisions that serve their own interests rather than the interests of the Afghan public (see Chapter 9, 9.4 Consideration of the public interest when making decisions and policies).

Representative bodies continue to enjoy the confidence of around two-thirds of respondents, including community shura and jirga (66\%), Provincial Councils (62\%), Community Development Councils (CDC) (61\%) and Parliament (59\%). While confidence in CDCs has remained stable since 2007, confidence in Provincial Councils appears to be falling slightly (from 69\% in 2007 to 65\% in 2008 and 62\% in 2009 and 2010). The same trend is evident regarding confidence in community shura and jirga which has declined from $71 \%$ in 2007 to $69 \%$ in 2008, 67\% in 2009 and 66\% in 2010 .

Respondents show greater ambivalence toward government institutions. A small majority express confidence in the public administration (57\%) and government ministers $(54 \%)$. This is consistent with the generally high levels of satisfaction with central government performance in most regions (see below, 7.2 Satisfaction with the performance of the central government and 7.3 Satisfaction with central government performance in policy and service delivery). It also reflects the perception that the government mostly considers the public interest rather than its own interests when making decisions (see Chapter 9, 9.4 Consideration of the public interest when making decisions and policies).

Confidence falls to $48 \%$ for the government justice system, which is consistent with the finding that the majority of respondents who had contact with the state courts in the last year encountered some level of corruption (see Chapter 8, 8.2 Payment of bribes), and that the majority of respondents think that state courts are corrupt and do not resolve cases promptly (see Chapter 10, 10.2 Perceptions of state courts).

A similarly low proportion of respondents have confidence in municipalities (46\%) which corroborates the low levels of satisfaction with the performance of municipal authorities compared to other local and central government institutions (see below, 7.5 Satisfaction with the performance of local government).

Levels of confidence with most public institutions have remained basically stable, with only minor fluctuations in recent years.

However, this is not true for the Independent Election Commission (IEC). Confidence in the IEC peaked in 2009 at $67 \%$ in the run up to the Presidential and Provincial Council elections, but has decreased significantly to $54 \%$ in 2010 . This 
decrease may be due to the contested performance of the IEC in the 2009 elections, which were marred by widespread irregularities and accusations of bias levelled at the Commission. This also reflects the relatively high proportion of respondents who say that the 2009 elections were not free and fair (38\%), which is nearly twice as many as those who, in 2009, had expected the elections would not be free and fair before they were held (22\%) (see Chapter 9, 9.10 Perceptions of the 2009 presidential elections).

Confidence in political parties also peaked at $47 \%$ in the run up to the 2009 elections, but fell back to $43 \%$ in 2010 , which is similar to the figures recorded in previous years.

Public confidence is again lowest for local militias, with just over one-third of respondents (34\%) expressing any level of confidence in them. This figure rose steadily from 2006 (from 31\% to 33\% in 2007, 36\% in 2008 and $37 \%$ in 2009), but decreased slightly to $34 \%$ in 2010 .

Public confidence in the various organizations and institutions listed is shown in the table below.

Table 7.1: Do you have a great deal of confidence, a fair amount of confidence, not very much confidence, or no confidence at all in the following institutions? (Q-34a-q, Base 6467)

\begin{tabular}{|c|c|c|c|c|c|}
\hline & & Great & $\begin{array}{l}\text { fidenc } \\
1+\mathrm{Fa}\end{array}$ & mount & \\
\hline & $\begin{array}{l}2006 \\
(\%)\end{array}$ & $\begin{array}{c}2007 \\
(\%)\end{array}$ & $\begin{array}{c}2008 \\
(\%)\end{array}$ & $\begin{array}{c}2009 \\
(\%)\end{array}$ & $\begin{array}{c}2010 \\
(\%)\end{array}$ \\
\hline Afghan National Army & 87 & 88 & 89 & 91 & 91 \\
\hline Afghan National Police & 86 & 83 & 82 & 84 & 79 \\
\hline Electronic media such as radio, TV & 84 & 74 & 76 & 70 & 71 \\
\hline Community Shuras/ Jirgas & - & 71 & 69 & 67 & 66 \\
\hline Provincial Councils & - & 69 & 65 & 62 & 62 \\
\hline Community Development Councils & - & 64 & 65 & 64 & 61 \\
\hline Parliament & - & - & - & - & 59 \\
\hline Public administration & - & 61 & 55 & 57 & 57 \\
\hline Newspapers, print media & 77 & 62 & 63 & 62 & 57 \\
\hline National NGOs & 57 & 59 & 62 & 61 & 55 \\
\hline Government Ministers & - & 58 & 51 & 53 & 54 \\
\hline Independent Election Commission & 65 & - & 57 & 67 & 54 \\
\hline International NGOs & 57 & 65 & 64 & 66 & 54 \\
\hline The Government Justice system & 38 & 48 & 46 & 46 & 48 \\
\hline The Municipality & - & 48 & 42 & 46 & 46 \\
\hline Political parties & 44 & 39 & 43 & 47 & 43 \\
\hline Local militias & 31 & 33 & 36 & 37 & 34 \\
\hline
\end{tabular}




\subsection{Satisfaction with the performance of the central government}

When asked to assess how they feel about the way the national government is carrying out its responsibilities, $73 \%$ of respondents give a positive assessment, including $17 \%$ who say that the government is doing a very good job and $56 \%$ who say it is doing quite a good job. Overall satisfaction with the performance of the national government has been rising slowly since 2008 (from 67\% to $71 \%$ in 2009 and $73 \%$ in 2010), although it has yet to reach the $80 \%$ satisfaction figure recorded in 2007.

Thinking of the national government, how do you feel about the way it is carrying out its responsibilities? (Q-37a) COMPARISON BETWEEN 2007, 2008, 2009 AND 2010

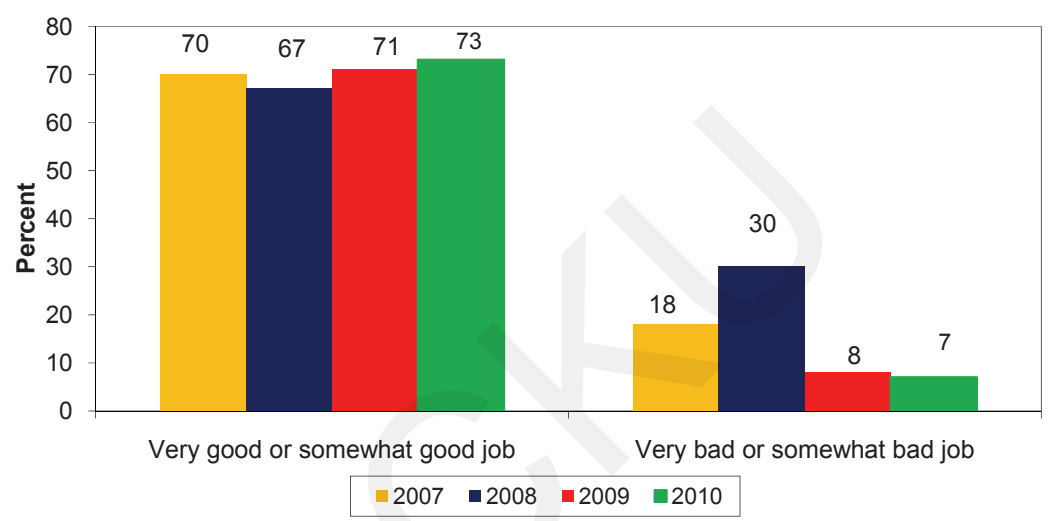

Fig 7.1

Women $(74 \%)$ are slightly more likely than men $(71 \%)$ to say that the national government is doing a very good job or somewhat good job in 2010. More respondents (78\%) in the lowest income group (those who earn less than Afs.2000 per month) say that the national government is doing a very good or a somewhat good job than those in higher income groups $(71 \%-74 \%)$.

There are more significant differences of opinion among ethnic groups. While more than four-fifths $(85 \%)$ of Uzbek respondents say the national government is doing a good job, this is true for just over two thirds $(69 \%)$ of Pashtun respondents.

There are also variations between regions. Satisfaction is highest in the North West, where Uzbeks are the largest ethnic group. In the North West region, more than four-fifths $(84 \%)$ of respondents state that the national government is doing a very good or somewhat good job. This is true for around three quarters in the East $(78 \%)$ and North East $(76 \%)$. These are also the regions that record the highest proportion 
of respondents who think the country is going in the right direction (see Chapter 2, 2.1 Direction of the country), and the highest levels of satisfaction with the performance of the national government for the provision of basic services (see below, 7.3 Satisfaction with central government performance in policy and service delivery). Conversely, the proportion of respondents who say the government is doing a good job is lowest in the South East $(65 \%)$, which is also the region where just over a third think that the country is going in the right direction, and satisfaction with the performance of the national government in providing basics services is amongst the lowest across all regions.

The 2010 survey records the highest levels of positive assessments of the national government performance since 2008 in all regions except the East. However perceptions have evolved differently over time in different regions. Positive assessments have been steadily increasing since 2008 in the West (from 61\% in 2008, 68\% in 2009 and $72 \%$ in 2010), the South East (from 56\% in 2008, 63\% in 2009 and 65\% in 2010) and the Central/Kabul regions (from 62\% in 2008, and 68\% in 2009 and 2010). However, in spite of the positive changes in public perceptions over time, about one-third of respondents in the Central/Kabul, South East, South West, and Central/Hazarajat regions think that the national government is performing poorly.

Table 7.2: Thinking of the national government, how do you feel about the way it is carrying out its responsibilities? (Q-37a) BY REGION - COMPARISON BETWEEN, 2008, 2009 AND 2010

\begin{tabular}{|c|c|c|c|c|c|c|c|c|}
\hline $\begin{array}{l}\text { Very Good } \\
\text { or somewhat } \\
\text { good job }\end{array}$ & $\begin{array}{c}\text { Central/ } \\
\text { Kabul } \\
(\%)\end{array}$ & $\begin{array}{l}\text { East } \\
(\%)\end{array}$ & $\begin{array}{c}\text { South } \\
\text { East } \\
(\%)\end{array}$ & $\begin{array}{c}\text { South } \\
\text { Wes } \\
(\%)\end{array}$ & $\begin{array}{l}\text { West } \\
(\%)\end{array}$ & $\begin{array}{c}\text { North } \\
\text { East } \\
(\%)\end{array}$ & $\begin{array}{c}\text { Central/ } \\
\text { Hazarajat } \\
(\%)\end{array}$ & $\begin{array}{c}\text { North } \\
\text { West } \\
(\%)\end{array}$ \\
\hline 2010 & 68 & 78 & 65 & 69 & 72 & 76 & 68 & 84 \\
\hline 2009 & 68 & 86 & 63 & 59 & 68 & 75 & 61 & 82 \\
\hline 2008 & 62 & 74 & 56 & 61 & 61 & 79 & 64 & 81 \\
\hline
\end{tabular}

\subsection{Satisfaction with central government performance in policy and service delivery}

The survey also asked people about the performance of the national government in specific areas such as education, health care, creating job opportunities, reviving/ developing the economy, maintaining relations with neighboring countries, fighting corruption and providing security. 
The government's performance is judged most positively with regard to the provision of basic public services such as education, health care and security. Eighty-five percent of respondents say the government is doing either a somewhat good job or a very good job in providing education. Sixty-three percent say the same about the provision of health care and a similar proportion $(62 \%)$ have the same view with respect to the provision of security. The majority of respondents also give a positive assessment of government performance in maintaining relations with neighboring countries $(57 \%)$.

On the other hand, around two-thirds of respondents say that the government is doing a bad job in creating jobs (67\%) and fighting corruption (69\%). Over half say the same about the government's performance in reviving/developing the economy (56\%). These findings are consistent with respondents' views of the availability of basic services and amenities in their local area, which show that they are most satisfied with the availability of education for children and the security situation, but least satisfied with the availability of jobs (see Chapter 6, 6.2 Facilities available in local area). This clearly suggests that the public's assessment of government performance is closely related to the ability of the government to provide basic public services at the local level.

Perceptions of the performance of the national government in specific areas (Q-37Ba-g, Base 6467)

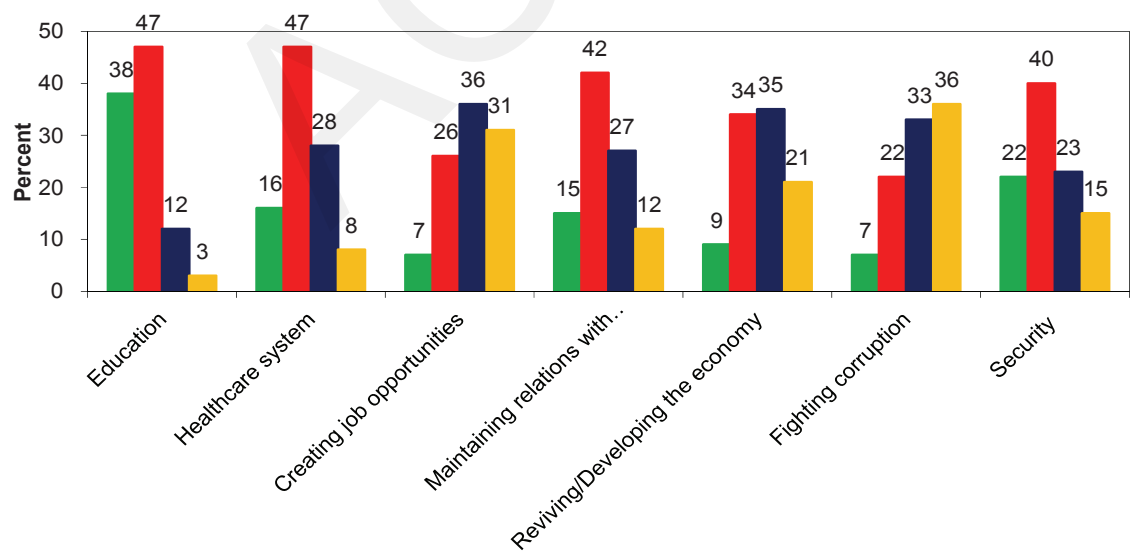

Fig 7.2

Respondents in urban areas give a more positive assessment of the performance of the national government regarding the provision of basic services such as education, health care and security than those in rural areas. The largest differences of opinion 
concern the provision of health care: $73 \%$ of urban respondents say the government is doing a good job in this regard, compared to $61 \%$ of respondents in rural areas. This is also true for the provision of security: 69\% of urban respondents give a positive assessment of the government's performance in this area compared to $59 \%$ in rural areas.

Across the country, the most positive assessments of government performance in almost all domains are reported in the East, with the exception of security and maintaining relations with neighboring countries. The highest levels of satisfaction regarding the provision of security are recorded in North West (82\%), Central/ Hazarajat (80\%) and North East (72\%). Although the North West also records high levels of satisfaction with most other government services, satisfaction with other services is generally low in the North East and Central/Hazarajat regions. However in all three of these regions, along with the East, the majority of respondents think the country is going in the right direction (see Chapter 2, 2.1 Direction of the country). This could suggest that the provision of security plays a greater role in respondents overall perceptions of the country than the provision of other basic services. The lowest levels of satisfaction across most domains are recorded in the South West and Central/Hazarajat, although satisfaction with government performance on economic issues including creating jobs, reviving the economy and tackling corruption, is also very low in the Central/Kabul region.

Table 7.3: Perceptions of the performance of the national government in specific areas - 'somewhat good job' and 'very good job' responses - (Q-37Ba-g, Base 6467) BY REGION

\begin{tabular}{|c|c|c|c|c|c|c|c|c|}
\hline & $\begin{array}{c}\text { Central/ } \\
\text { Kabul } \\
(\%)\end{array}$ & $\begin{array}{l}\text { East } \\
(\%)\end{array}$ & $\begin{array}{c}\text { South } \\
\text { East } \\
(\%)\end{array}$ & \begin{tabular}{|c|} 
South \\
West \\
$(\%)$
\end{tabular} & $\begin{array}{l}\text { West } \\
(\%)\end{array}$ & $\begin{array}{c}\text { North } \\
\text { East } \\
(\%)\end{array}$ & $\begin{array}{c}\text { Central/ } \\
\text { Hazarajat } \\
(\%)\end{array}$ & $\begin{array}{c}\text { North } \\
\text { West } \\
(\%)\end{array}$ \\
\hline a) Education & 89 & 92 & 84 & 66 & 80 & 87 & 86 & 88 \\
\hline b) Health care system & 69 & 72 & 61 & 49 & 67 & 62 & 52 & 63 \\
\hline c) Creating job opportunities & 22 & 50 & 30 & 41 & 36 & 29 & 23 & 36 \\
\hline $\begin{array}{l}\text { d) Maintaining relations with } \\
\text { neighboring countries }\end{array}$ & 61 & 59 & 63 & 41 & 50 & 58 & 43 & 65 \\
\hline $\begin{array}{l}\text { e) Reviving/Developing the } \\
\text { economy }\end{array}$ & 38 & 52 & 53 & 37 & 42 & 40 & 31 & 47 \\
\hline f) Fighting corruption & 25 & 39 & 25 & 32 & 27 & 31 & 29 & 33 \\
\hline g) Security & 66 & 59 & 37 & 43 & 54 & 72 & 80 & 82 \\
\hline
\end{tabular}




\subsection{Important achievements and failings of the central government}

The survey also asked respondents to identify the most important achievements of the central government in the past two years. The achievements mentioned most frequently are a better education system (mentioned by $27 \%$ of respondents), establishing peace and security (24\%) and reconstruction (24\%). The achievements of government identified by respondents are broadly similar to the reasons for optimism given by respondents who say that the country is moving in the right direction (see Chapter 2, 2.2 Reasons for optimism), which could suggest that respondents consider government to play a critical role in leading the country toward positive development. These findings are also consistent with the positive assessment of the availability of education and the security situation in local areas (see Chapter 6, 6.2 Facilities available in local area) and the high levels of satisfaction with central government performance in relation to education (which comes in first place) and security (which comes in third place) (see above, 7.3 Satisfaction with central government performance in policy and service delivery).

What in your opinion is the most important achievement of the current government in the past few years? And what is next? (Q-39a®b, Base 6467) (Percentages based on multiple responses)

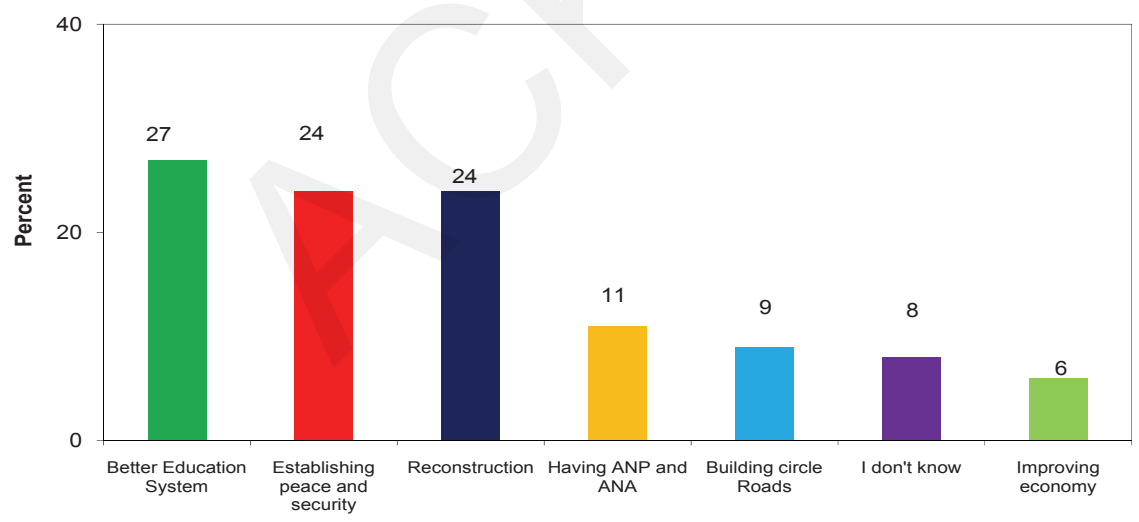

Fig. 7.3

Improvements in the education system are most often mentioned as the most important acheivement of the current government in the South East (33\%) and North East $(31 \%)$ regions. Establishing peace and security is the achievement most often identified in the Central/Hazarajat where it is mentioned by just under half $(47 \%)$ of respondents, and in the North West where it is mentioned by over a third (35\%). Reconstruction is the government achievement mentioned most often in the Central/ Kabul (31\%) region, and is also highlighted in the North West (30\%). 
Table 7.4: What in your opinion is the most important achievement of the current government in the past few years? And what is next? (Q-39a\&\%, Base 6467) (Percentages based on multiple responses) ALL AND BY REGION

\begin{tabular}{|c|c|c|c|c|c|c|c|c|c|}
\hline & $\begin{array}{l}\text { All } \\
(\%)\end{array}$ & $\begin{array}{c}\text { Central } \\
\text { /Kabul } \\
(\%)\end{array}$ & \begin{tabular}{|c|} 
East \\
$(\%)$
\end{tabular} & \begin{tabular}{|c|} 
South \\
East \\
$(\%)$
\end{tabular} & \begin{tabular}{|c|} 
South \\
West \\
$(\%)$
\end{tabular} & $\begin{array}{l}\text { West } \\
(\%)\end{array}$ & $\begin{array}{c}\text { North } \\
\text { East } \\
(\%)\end{array}$ & $\begin{array}{c}\text { Central/ } \\
\text { Hazarajat } \\
(\%)\end{array}$ & $\begin{array}{c}\text { North } \\
\text { West } \\
(\%)\end{array}$ \\
\hline Better education system & 27 & 25 & 23 & 33 & 23 & 26 & 31 & 34 & 27 \\
\hline $\begin{array}{l}\text { Establishing peace and } \\
\text { security }\end{array}$ & 24 & 22 & 22 & 10 & 11 & 24 & 29 & 47 & 35 \\
\hline Reconstruction & 24 & 31 & 18 & 24 & 19 & 21 & 22 & 9 & 30 \\
\hline Having ANP and ANA & 11 & 10 & 14 & 19 & 14 & 10 & 15 & 5 & 4 \\
\hline Building circle roads & 9 & 9 & 8 & 12 & 12 & 4 & 7 & 11 & 13 \\
\hline Don’t know & 8 & 8 & 8 & 4 & 12 & 12 & 3 & 10 & 6 \\
\hline Elections & 6 & 4 & 8 & 6 & 6 & 7 & 6 & 4 & 4 \\
\hline Improving economy & 6 & 5 & 9 & 6 & 3 & 4 & 12 & 3 & 4 \\
\hline
\end{tabular}

The survey also asked respondents to identify the most important failings of the central government in the past two years. The failings most frequently identified are administrative corruption (identified by $37 \%$ of respondents), insecurity (30\%) and lack of job opportunities (17\%). Around one in ten respondents identify weak government $(10 \%)$, weak economy $(9 \%)$ and failure to remove the Taliban $(9 \%)$ as significant government failings. The issues identified as failings of the central government closely mirror the reasons given by respondents who believe that the country is moving in the wrong direction (see Chapter 2, 2.3 Reasons for pessimism). However, corruption is given greater emphasis than insecurity as a government failure, which could suggest that respondents feel the government is better placed to tackle this issue but has failed to do so. This is borne out by respondents' experience that between $30 \%$ and $50 \%$ of contacts with core government institutions involve some level of corruption (see Chapter 8, 8.2 Payment of bribes).

Security issues are identified as both an achievement and a failing of the government, which is likely due to the wide variation in the security conditions in different parts of the country. 
What in your opinion is the most important failing of the central government in the past two years? And what is next? (Q-40a\&b, Base 6467) (Percentages based on multiple responses)

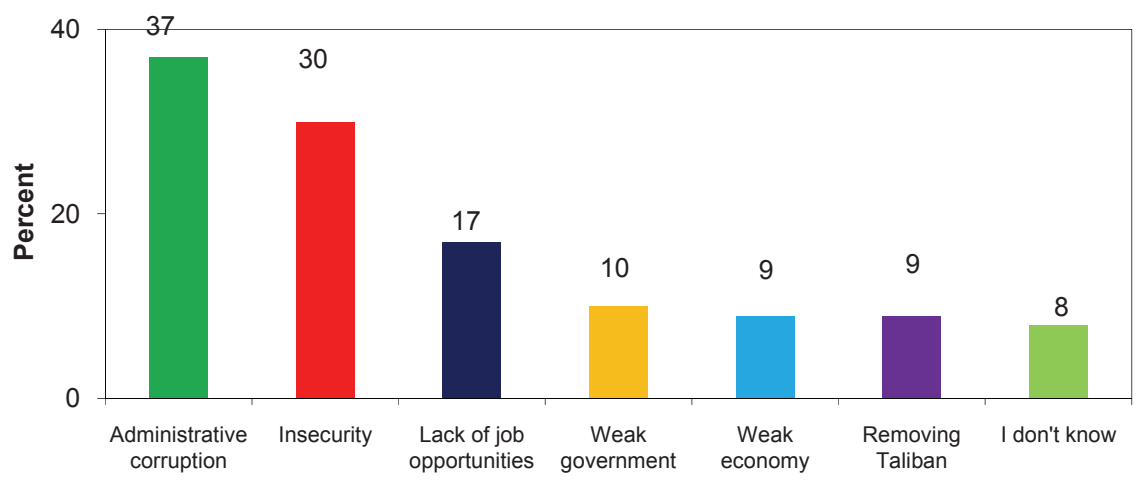

Fig. 7.4

Administrative corruption is mentioned most frequently as the most important failing of the central government in the North West (43\%), North East and South East $(42 \%)$ regions.

The inability to ensure security is the most frequently identified central government failing in the South East (42\%), West (34\%), East (33\%) and Central/Kabul (33\%) regions, but least frequently mentioned in the Central/Hazarajat region (21\%), North East $(24 \%)$ and North West (25\%). This mirrors the high level of satisfaction with the performance of government in regards to security in the North West (82\%) and Central/Hazarajat region, where $80 \%$ of respondents say the government is doing a good job, and the correspondingly low levels of satisfaction recorded in the South East where only $37 \%$ of respondents say the government is doing a good job in the provision of security (see Table 7.3). Failure to remove the Taliban is specifically mentioned as a failing of government by one in six respondents in the North West $(15 \%)$ and one in ten in the West $(11 \%)$ and South East $(10 \%)$.

Weak government is mentioned by between $10 \%$ and $14 \%$ of respondents in all regions except the East $(7 \%)$ and the North West (6\%).

The lack of job opportunities is mentioned most in the Central/Hazarajat (22\%), Central/Kabul (21\%) and North East (19\%) regions. The weak economy is also most frequently mentioned in the Central/Hazarajat region $(17 \%)$.

In three regions at least one in ten respondents is unable or unwilling to mention any failings of central government; the West (13\%), South West (11\%) and Central/ Hazarajat (11\%). However, these figures are much lower than in 2009 (West 24\%, South West 21\% and Central/Hazarajat 47\%). 
Table 7.5: What in your opinion is the most important failing of the central government in the past two years? And what is next? (Q-40a\&b, Base 6467) (Percentages based on multiple responses) BY REGION AND ALL

\begin{tabular}{|c|c|c|c|c|c|c|c|c|c|}
\hline & $\begin{array}{l}\text { All } \\
(\%)\end{array}$ & $\begin{array}{c}\text { Central } \\
/ \text { Kabul } \\
(\%)\end{array}$ & $\begin{array}{l}\text { East } \\
(\%)\end{array}$ & $\begin{array}{c}\text { South } \\
\text { East } \\
(\%)\end{array}$ & \begin{tabular}{|c|} 
South \\
West \\
$(\%)$
\end{tabular} & $\begin{array}{l}\text { West } \\
(\%)\end{array}$ & $\begin{array}{c}\text { North } \\
\text { East } \\
(\%)\end{array}$ & $\begin{array}{c}\text { Central/ } \\
\text { Hazarajat } \\
(\%)\end{array}$ & $\begin{array}{c}\text { North } \\
\text { West } \\
(\%)\end{array}$ \\
\hline Administrative corruption & 37 & 37 & 34 & 42 & 31 & 35 & 42 & 31 & 43 \\
\hline Insecurity & 30 & 33 & 33 & 42 & 34 & 26 & 24 & 21 & 25 \\
\hline Lack of job opportunities & 17 & 21 & 14 & 16 & 10 & 14 & 19 & 22 & 19 \\
\hline Weak Government & 10 & 10 & 7 & 13 & 12 & 12 & 12 & 14 & 6 \\
\hline Weak economy & 9 & 10 & 5 & 8 & 5 & 9 & 12 & 17 & 12 \\
\hline Removing the Taliban & 9 & 7 & 9 & 6 & 6 & 11 & 10 & 8 & 15 \\
\hline Don't know & 8 & 7 & 9 & 3 & 11 & 13 & 3 & 11 & 8 \\
\hline Removing drugs & 6 & 6 & 5 & 7 & 5 & 8 & 4 & 3 & 8 \\
\hline Bad education system & 5 & 4 & 8 & 4 & 6 & 4 & 4 & 8 & 7 \\
\hline Lack of unity among tribes & 4 & 3 & 4 & 2 & 3 & 5 & 4 & 9 & 5 \\
\hline Suicide attacks & 4 & 5 & 8 & 5 & 4 & 4 & 4 & 1 & 4 \\
\hline
\end{tabular}

\subsection{Satisfaction with the performance of local government}

Respondents were also asked to assess the performance of the local government in their area, which includes Provincial Councils, Municipalities and District Councils.

Slightly more than three quarters of respondents (78\%) assess their provincial government positively, including around a quarter $(23 \%)$ who say that the provincial government is doing a very good job. These findings are entirely consistent with the findings of previous years.

However, assessments of the performance of the provincial government vary between regions. Although the overall assessment of the performance of provincial government is positive in all regions, the highest levels of satisfaction are recorded in the North West (87\%) and Central/Kabul (80\%) regions, where more than four out of five respondents say that the provincial government is doing a good job. At a provincial level, the highest levels of satisfaction are recorded in Badakhshan (98\%), Samangan (95\%), Badghis (95\%), Jawzjan (94\%), Balkh (91\%), Panjshir (89\%), Kabul $(86 \%)$ and Paktia $(86 \%)$ provinces. 
On the other hand, the highest levels of dissatisfaction are recorded in the South West $(29 \%)$ and South East $(28 \%)$ where more than a quarter of respondents say the provincial government is doing a bad job. The highest level of dissatisfaction is recorded in Zabul province where over half (52\%) of the respondents say that their provincial government is doing a bad job. This is also true for around one-third of respondents in Paktika (37\%), Kunduz (36\%), Kapisa (35\%), Kunar (35\%), Ghazni (33\%), Nuristan (33\%), Wardak (31\%) and Baghlan (30\%) provinces.

Turning to your Provincial Government, do you think that overall it is doing a very good job, somewhat good job, somewhat bad job or a very bad job? (Q-38a, Base 6467) BY REGION

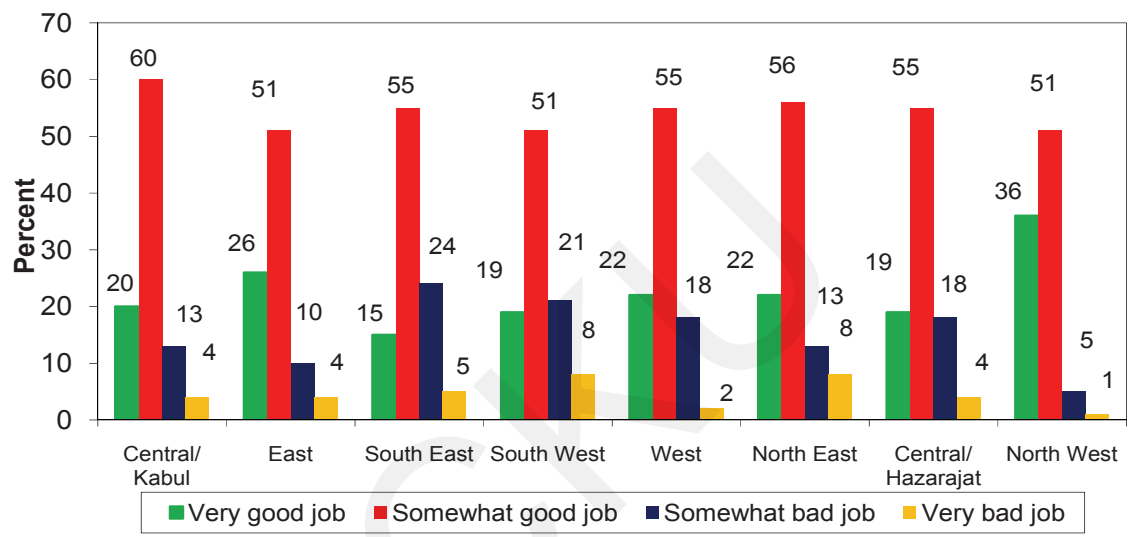

Fig 7.5

The survey also asked about the performance of municipal and district authorities. People living in urban areas (21\% of all respondents) were asked questions pertaining to municipal authorities. A small majority (54\%) of urban respondents think that the municipal authority in their local area is doing a good job, including $12 \%$ who think it is doing a very good job. However, the level of satisfaction with municipal government performance is significantly lower than for central government $(73 \%)$ and provincial government $(78 \%)$ which around three quarters of respondents say are doing a good job. Over two-thirds $(40 \%)$ of respondents give a negative assessment of the performance of the municipality in their locality, including $14 \%$ who said that it is doing a very bad job.

The most positive assessments of the performance of municipal authorities are in the East where almost four out of five respondents (83\%) say their local municipality is doing a good job. Over three quarters of respondents in the South East (78\%) and over two-thirds in the North West (68\%) and West (66\%) say the same. On the other 
hand, the highest levels of dissatisfaction are recorded in the Central/Hazarajat ${ }^{2}$ (51\%), South West (51\%), and Central/Kabul (49\%) regions where around half of respondents say that their local municipal authorities are doing a bad job.

It is worth noting that the proportion of respondents who are unable or unwilling to answer this question is very high in the Central/Hazarajat (42\%), North East (26\%), West $(15 \%)$ and North West (13\%) regions.

[URBAN RESIDENTS ONLY] Turning to elements of the Municipal authorities, do you think that overall it is doing a very good job, somewhat good job, somewhat bad job or a very bad job? (Q_38b, Base - 1390) BY REGION

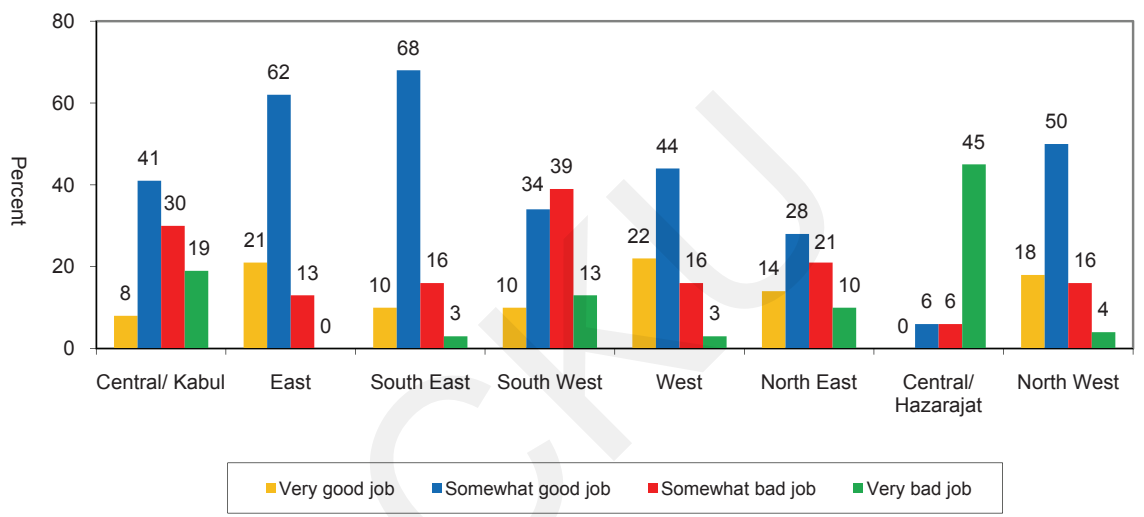

Fig 7.6

Nationally, the overall level of satisfaction with the performance of municipal authorities slightly decreased in 2010 (54\%) compared to 2009 (58\%). However, satisfaction decreased significantly in the North West (from 88\% in 2009 to $68 \%$ in 2010), North East (from 62\% in 2009 to 42\% in 2010), and South West (from 55\% in 2009 to $44 \%$ in 2010) and Central Hazarajat ${ }^{3}$. On the other hand, the proportion of respondents who say that their municipal authorities are doing a good job increased in the East (from $71 \%$ in 2009 to $83 \%$ in 2010), West (from $56 \%$ in 2009 to $66 \%$ in 2010 ) and South East (from $71 \%$ in 2009 to $78 \%$ in 2010 ).

2 It is worth noting that the sample of urban residents in the Central/Hazarajat region is very small (17 respondents) due to the small urban population size.

3 The large decrease in satisfaction reported in the Central/Hazarajat region seen on the graph is likely to be a function of the small sample of urban residents in this region, and should be interpreted with caution. 
Table 7.6: [URBAN RESIDENTS ONLY] Turning to elements of the Municipal authorities, do you think that overall it is doing a very good job, somewhat good job, somewhat bad job or a very bad job? Sum of very and somewhat good job - (Q_38b) COMPARISON OF 2008, 2009 and 2010 BY REGION

\begin{tabular}{|c|c|c|c|c|c|c|c|c|c|}
$\begin{array}{c}\text { Very Good or } \\
\text { somewhat good job }\end{array}$ & $\begin{array}{c}\text { All } \\
\mathbf{( \% )}\end{array}$ & $\begin{array}{c}\text { Central/ } \\
\text { Kabul } \\
\mathbf{( \% )}\end{array}$ & $\begin{array}{c}\text { East } \\
\mathbf{( \% )}\end{array}$ & $\begin{array}{c}\text { South } \\
\text { East } \\
\mathbf{( \% )}\end{array}$ & $\begin{array}{c}\text { South } \\
\text { West } \\
\mathbf{( \% )}\end{array}$ & $\begin{array}{c}\text { West } \\
\mathbf{( \% )}\end{array}$ & $\begin{array}{c}\text { North } \\
\text { East } \\
\mathbf{( \% )}\end{array}$ & $\begin{array}{c}\text { Central/ } \\
\text { Hazarajat } \\
\mathbf{( \% )}\end{array}$ & $\begin{array}{c}\text { North } \\
\text { West } \\
(\mathbf{\%})\end{array}$ \\
\hline $\mathbf{2 0 1 0}$ & $\mathbf{5 3}$ & $\mathbf{5 9}$ & $\mathbf{8 3}$ & $\mathbf{7 8}$ & $\mathbf{4 4}$ & $\mathbf{6 6}$ & $\mathbf{4 2}$ & $\mathbf{6}$ & $\mathbf{6 8}$ \\
\hline 2009 & 58 & 50 & 71 & 71 & 55 & 56 & 62 & 56 & 88 \\
\hline 2008 & 50 & 50 & 50 & 60 & 58 & 31 & 44 & - & 63 \\
\hline 2007 & 57 & 64 & 59 & 48 & 58 & 53 & 67 & 28 & 67 \\
\hline
\end{tabular}

The survey asked a similar question about the performance of local authorities to people living in rural areas (78\% of all respondents). Sixty-one percent of respondents rate the performance of their local authorities positively, which is higher than the level of positive assessments of the performance of municipal authorities in urban areas (53\%). However, around a third (32\%) of respondents nationally thinks the local authority in their locality is doing a bad job.

The largest proportions of respondents who say that their local authority is doing a good job are in the North West (76\%), Central/Hazarajat (71\%), North East (68\%) and East (65\%). The highest levels of dissatisfaction, where nearly half of respondents say that their local authorities are doing a bad job, are recorded in the South West $(50 \%)$ and South East $(45 \%)$. Around one in three respondents say the same in the East (33\%), West (33\%) and Central/Kabul (32\%) regions.

[RURAL RESIDENTS ONLY] Turning to elements of the Local authorities, do you think that overall it is doing a very good job, somewhat good job, somewhat bad job or a very bad job? (Q-38c, Base - 5076) BY REGION

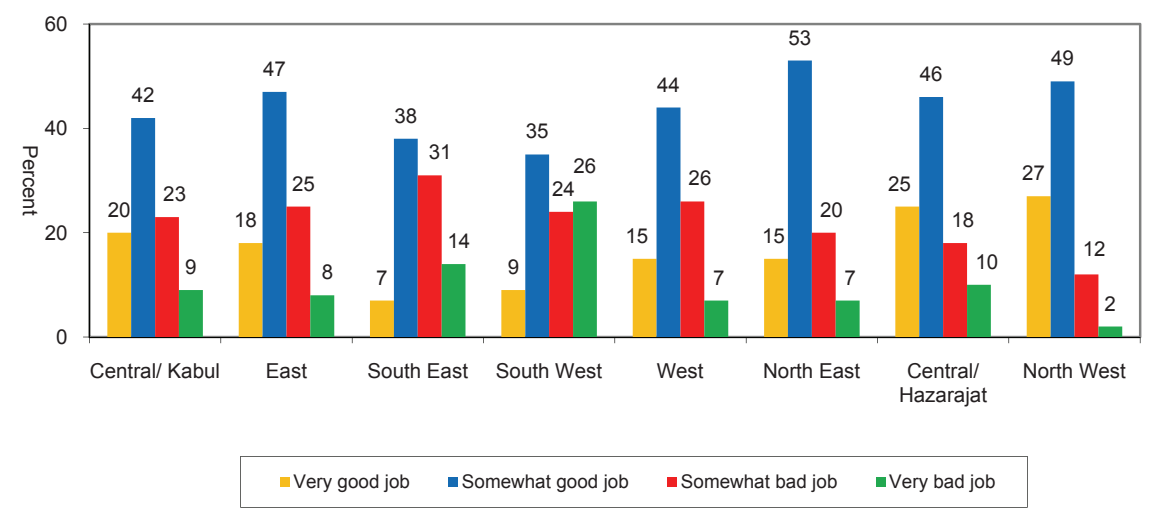

Fig 7.7 
Positive assessments of the performance of local authorities decreased in almost all regions in 2010 compared to 2009. The only region where the level of satisfaction increased is in the Central/Hazarajat (from 58\% in 2009 to $71 \%$ in 2010).

Table 7.7: [RURAL RESIDENTS ONLY] Turning to elements of the Local authorities, do you think that overall it is doing a very good job, somewhat good job, somewhat bad job or a very bad job? Sum of very good and somewhat good job - (Q-38c) COMPARISON OF 2008, 2009 AND 2010 BY REGION AND ALL

\begin{tabular}{|c|c|c|c|c|c|c|c|c|c|}
$\begin{array}{c}\text { Very Good or } \\
\text { somewhat good job }\end{array}$ & All & $\begin{array}{c}\text { Central/ } \\
\text { Kabul }\end{array}$ & East & $\begin{array}{c}\text { South } \\
\text { East }\end{array}$ & $\begin{array}{c}\text { South } \\
\text { West }\end{array}$ & West & $\begin{array}{c}\text { North } \\
\text { East }\end{array}$ & $\begin{array}{c}\text { Central/ } \\
\text { Hazarajat }\end{array}$ & $\begin{array}{c}\text { North } \\
\text { West }\end{array}$ \\
\hline $\mathbf{2 0 1 0}$ & $\mathbf{6 1}$ & $\mathbf{6 2}$ & $\mathbf{6 5}$ & $\mathbf{4 5}$ & $\mathbf{4 4}$ & $\mathbf{5 9}$ & $\mathbf{6 8}$ & $\mathbf{7 1}$ & $\mathbf{7 6}$ \\
\hline 2009 & 69 & 73 & 77 & 60 & 50 & 67 & 76 & 58 & 81 \\
\hline 2008 & 67 & 76 & 54 & 76 & 59 & 81 & 53 & 85 & 64 \\
\hline
\end{tabular}

On the whole, public perceptions of the performance of different levels of government reveal that people are most positive about the performance of their provincial government, followed by the national government and rural district authorities. They are least satisfied with the performance of municipalities. This mirrors the levels of public confidence recorded for these different institutions, which are highest for provincial councils $(62 \%)$ followed by national government institutions such as parliament (59\%) and the Public Administration (57\%) and lowest for municipal authorities $(54 \%)$ (see above, 7.1 Confidence in public institutions). This correlation reinforces the clear link between performance and public trust in government institutions.

Table 7.8: Proportions of respondents who say the national government, provincial government, municipality and local authorities are doing a good job (combination of very good job and somewhat good job) COMPARISON BETWEEN 2007, 2008, 2009 AND 2010

\begin{tabular}{|l|c|c|c|c|}
\hline & 2007 & 2008 & 2009 & 2010 \\
\hline National government & 80 & 67 & 71 & 73 \\
\hline Provincial government & 80 & 74 & 75 & 78 \\
\hline Municipal authority & 57 & 50 & 58 & 54 \\
\hline Local authority & - & 67 & 69 & 61 \\
\hline
\end{tabular}




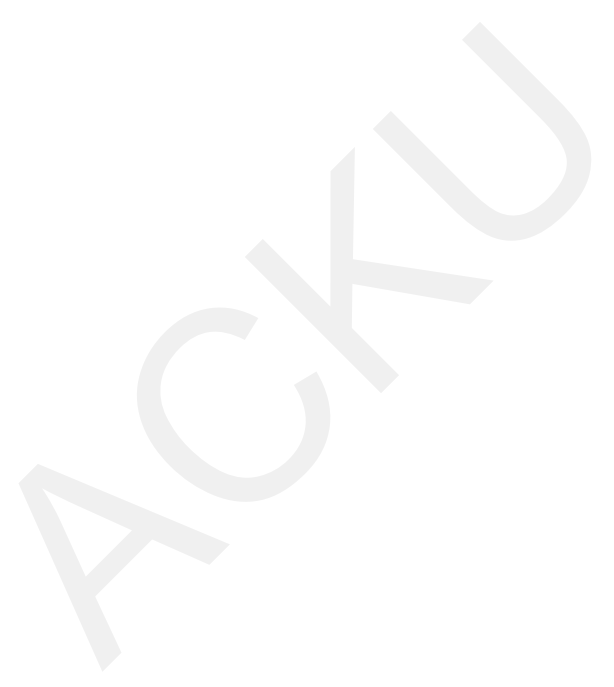




\section{Corruption}

\subsection{Corruption - major or minor problem}

Respondents consistently identify corruption as one of the biggest problems facing Afghanistan (see Chapter 2, 2.4: Afghanistan's biggest problems: National level). The level of corruption in public institutions is also an important measure of government performance. The survey therefore sought to measure public perceptions of the prevalence of corruption in various facets of life and at different levels of government. Respondents were asked whether they think corruption is a major problem, a minor problem or no problem at all in their daily life, their neighborhood, their local authorities, their provincial government and in Afghanistan as a whole.

The survey shows that the majority of Afghans think that corruption is a major problem in all facets of life and at all levels of government. In addition, the perception of the prevalence of corruption rises as the level of the institution rises. A little more than half of respondents say corruption is a major problem in their daily life (55\%), their neighborhood (50\%) and their local authorities (56\%). Around two-thirds say that corruption is a major problem in their provincial government $(65 \%)$ whereas around three quarters think that corruption is a major problem for Afghanistan as a whole $(76 \%)$.

Table 8.1: Please tell me whether you think that corruption is a major problem, a minor problem, or no problem at all in the following area (Q23a-e, Base 6467)

\begin{tabular}{|l|c|c|c|} 
& $\begin{array}{c}\text { Major } \\
\text { Problem } \\
\mathbf{( \% )}\end{array}$ & $\begin{array}{c}\text { Minor } \\
\text { Problem } \\
(\mathbf{\%})\end{array}$ & $\begin{array}{c}\text { Not a } \\
\text { Problem } \\
\mathbf{( \% )}\end{array}$ \\
\hline a) In your daily life & 55 & 28 & 16 \\
\hline b) In your neighborhood & 50 & 33 & 15 \\
\hline c) In your local authorities & 56 & 33 & 9 \\
\hline d) In your provincial government & 65 & 26 & 7 \\
\hline e) In Afghanistan as a whole & 76 & 17 & 5 \\
\hline
\end{tabular}

There is some variation in the perception of corruption across regions. The proportion of respondents who say that corruption is a major problem in Afghanistan as a whole, is highest in the Central/Kabul (85\%) and Central/Hazarajat (81\%) regions. The Central/Hazarajat region also records the highest proportion of respondents who say that corruption is a major problem at provincial government (74\%), local authority $(66 \%)$ and neighborhood $(63 \%)$ levels. The perception of corruption as a major problem in daily life is highest in the East (63\%) and the West (63\%).

The proportion of respondents who say that corruption is a major problem is lowest in the North West for all mentioned levels, except for the country as a whole, which is slightly lower in the East. 
Table 8.2: Please tell me whether you think that corruption is a major problem, a minor problem, or no problem at all in the following area (Q23a-e, Base 6467) BY REGION. Major Problem responses

\begin{tabular}{|c|c|c|c|c|c|c|c|c|c|}
\hline & $\begin{array}{l}\text { All } \\
(\%)\end{array}$ & $\begin{array}{c}\text { Central/ } \\
\text { Kabul } \\
(\%)\end{array}$ & $\begin{array}{c}\text { East } \\
(\%)\end{array}$ & $\begin{array}{c}\text { South } \\
\text { East } \\
(\%)\end{array}$ & $\begin{array}{c}\text { South } \\
\text { West } \\
(\%)\end{array}$ & $\begin{array}{l}\text { West } \\
(\%)\end{array}$ & $\begin{array}{l}\text { North } \\
\text { East } \\
(\%)\end{array}$ & $\begin{array}{c}\text { Central / } \\
\text { Hazarajat } \\
(\%)\end{array}$ & $\begin{array}{c}\text { North } \\
\text { West } \\
(\%)\end{array}$ \\
\hline Daily Life & 55 & 58 & 63 & 54 & 56 & 63 & 53 & 60 & 36 \\
\hline Neighborhood & 50 & 54 & 56 & 50 & 54 & 53 & 48 & 63 & 35 \\
\hline Local authorities & 56 & 62 & 59 & 61 & 46 & 57 & 58 & 66 & 41 \\
\hline Provincial Gov. & 65 & 71 & 61 & 70 & 53 & 69 & 66 & 74 & 53 \\
\hline $\begin{array}{l}\text { Afghanistan as a } \\
\text { whole }\end{array}$ & 76 & 85 & 71 & 78 & 58 & 75 & 79 & 81 & 74 \\
\hline
\end{tabular}

This pattern is consistent with previous years. The perception of corruption in Afghanistan as a whole has remained stable. The proportion of respondents that identify corruption as a major problem in their provincial government has fluctuated slightly over the last few years, although it has increased in 2010 to $65 \%$, compared to $61 \%$ in 2009 , bringing it close to the highest figure recorded in 2006 (66\%). By contrast, perceptions of corruption as a major problem at the local authority level have been rising steadily, from 48\% in 2007, to 53\% in 2008 and 2009 and 56\% in 2010. The same trend is evident with respect to the perception of corruption as a major problem in daily life which has been rising steadily from 42\% in 2006 to 55\% in 2010.

Table 8.3: Percentage of the people who think corruption is a major problem in various facets of life and levels of government (Q23a-e) COMPARISON BETWEEN 2006, 2007, 2008, 2009 AND 2010

\begin{tabular}{|l|c|c|c|c|c|}
\hline In your daily life & $\begin{array}{c}\mathbf{2 0 0 6} \\
\mathbf{( \% )}\end{array}$ & $\begin{array}{c}\mathbf{2 0 0 7} \\
\mathbf{( \% )}\end{array}$ & $\begin{array}{c}\mathbf{2 0 0 8} \\
\mathbf{( \% )}\end{array}$ & $\begin{array}{c}\mathbf{2 0 0 9} \\
\mathbf{( \% )}\end{array}$ & $\begin{array}{c}\mathbf{2 0 1 0} \\
\mathbf{( \% )}\end{array}$ \\
\hline In your neighborhood & 42 & 47 & 51 & 53 & 55 \\
\hline In your local authorities & 40 & 43 & 48 & 50 & 50 \\
\hline In your provincial government & - & 48 & 53 & 53 & 56 \\
\hline In Afghanistan as a whole & 66 & 60 & 63 & 61 & 65 \\
\hline
\end{tabular}

The survey attempted to further explore trends in public perceptions of corruption by asking respondents to compare the level of corruption now with one year ago. The majority of respondents $(53 \%)$ think that the amount of corruption has increased in Afghanistan as a whole, while $44 \%$ think this about the provincial government. A third of respondents $(34 \%)$ think that corruption has increased in their local authorities and around a quarter believe this is true in their neighborhood (24\%) and in their daily lives $(27 \%)$. The findings suggest that respondents are more likely to identify an increase in corruption in domains where they perceive corruption to be generally high. 
Table 8.4: Percentage of the people who think the amount of corruption has increased in various facets of life and levels of government (Q-24a-e, Base 6467)

\begin{tabular}{|l|c|c|c|} 
& $\begin{array}{c}\text { Increased } \\
\mathbf{( \% )}\end{array}$ & $\begin{array}{c}\text { Stayed the same } \\
\mathbf{( \% )}\end{array}$ & $\begin{array}{c}\text { Decreased } \\
\mathbf{( \% )}\end{array}$ \\
\hline a) In your daily life & 27 & 48 & 23 \\
\hline b) In your neighborhood & 24 & 51 & 23 \\
\hline c) In your local authorities & 34 & 46 & 17 \\
\hline d) In your provincial government & 44 & 38 & 13 \\
\hline e) In Afghanistan as a whole & 53 & 30 & 11
\end{tabular}

The highest proportion of respondents who think corruption has increased in their daily life is recorded in the East (42\%). Perceptions of an increase in corruption in local government are highest in the North East and South East for both provincial government (58\% in the North East, 51\% in the South East) and local authorities (43\% in the South East, $40 \%$ in the North East). The North East also records the highest proportion of respondents who say corruption has increased in Afghanistan as a whole $(65 \%)$, followed by the Central/Kabul region $(60 \%)$.

Perceptions of an annual increase in corruption are lowest in the Central/Hazarajat and North West at all levels except for the country as a whole, where the proportions are equally low in the East and the West.

Table 8.5: Compared to a year ago, do you think the amount of corruption overall in various facets of life and levels of government has increased, stayed the same or decreased? (Q-24a-e, Base 6467)

\section{BY REGION}

\begin{tabular}{|l|c|c|c|c|c|c|c|c|c|} 
& All & $\begin{array}{c}\text { Central/ } \\
\text { Kabul } \\
(\%)\end{array}$ & $\begin{array}{c}\text { East } \\
(\%)\end{array}$ & $\begin{array}{c}\text { South } \\
\text { East } \\
(\%)\end{array}$ & $\begin{array}{c}\text { South } \\
\text { West } \\
(\%)\end{array}$ & $\begin{array}{c}\text { West } \\
(\%)\end{array}$ & $\begin{array}{c}\text { North } \\
\text { East } \\
(\%)\end{array}$ & $\begin{array}{c}\text { Central / } \\
\text { Hazarajat } \\
(\%)\end{array}$ & $\begin{array}{c}\text { North } \\
\text { West } \\
(\%)\end{array}$ \\
\hline Daily Life & 27 & 25 & 42 & 25 & 33 & 28 & 30 & 12 & 15 \\
\hline Neighborhood & 21 & 24 & 32 & 31 & 30 & 20 & 27 & 17 & 11 \\
\hline $\begin{array}{l}\text { Local authorities } \\
\text { Provincial }\end{array}$ & 34 & 36 & 38 & 43 & 35 & 29 & 40 & 25 & 18 \\
\hline Government & 44 & 46 & 45 & 51 & 41 & 39 & 58 & 37 & 32 \\
\hline Afghanistan as a whole & 53 & 60 & 49 & 55 & 41 & 48 & 65 & 48 & 49 \\
\hline
\end{tabular}

Perceptions of the annual increase in corruption have remained relatively stable over time although some weak trends are evident. In 2010 there is a slight rise in the proportion of respondents who say corruption has increased in the last year at most levels. The perception that corruption has increased in daily life has gone up from $23 \%$ in 2009 to $27 \%$ in 2010 . There is also a small increase among those who say that corruption has increased in their provincial government from $41 \%$ in 2009 to $44 \%$ in 2010 . This finding reverses the previous trend which saw the proportion fall 
steadily from 50\% in 2006 to $45 \%$ in 2007 and 2008 to $41 \%$ in 2009 . By contrast there has been a consistent fall in the proportion of respondents who say there has been an annual increase in corruption in Afghanistan as a whole from 60\% in 2006 to $53 \%$ in 2010 .

Table 8.6: Percentage of the people who think the amount of corruption has increased in various facets of life and levels of government (Q-24a-e) COMPARISON BETWEEN 2006, 2007, 2008, 2009 AND 2010

\begin{tabular}{|l|c|c|c|c|c|} 
& $\begin{array}{c}\mathbf{2 0 0 6} \\
\mathbf{( \% )}\end{array}$ & $\begin{array}{c}\mathbf{2 0 0 7} \\
\mathbf{( \% )}\end{array}$ & $\begin{array}{c}\mathbf{2 0 0 8} \\
\mathbf{( \% )}\end{array}$ & $\begin{array}{c}\mathbf{2 0 0 9} \\
\mathbf{( \% )}\end{array}$ & $\begin{array}{c}\mathbf{2 0 1 0} \\
\mathbf{( \% )}\end{array}$ \\
\hline In your daily life & 24 & 21 & 24 & 23 & 27 \\
\hline In your neighborhood & 28 & 21 & 25 & 24 & 24 \\
\hline In your local authorities & - & 31 & 33 & 32 & 34 \\
\hline In your provincial government & 50 & 45 & 45 & 41 & 44 \\
\hline In Afghanistan as a whole & 60 & 57 & 57 & 54 & 53 \\
\hline
\end{tabular}

\subsection{Payment of bribes}

The survey also sought to measure respondents' personal experience of corruption in various facets of public life by asking how often in the past year they had to give cash or a gift or perform a favor for a government official. Survey findings show that between a third and a half of respondents had no contact with officials in the institutions mentioned, which means that they were not in a position to experience corruption directly. The situations in which respondents have most frequently encountered corruption in the form of an obligation to pay a bribe are in accessing public health care services (33\%) and in contacts with the Afghan National Police $(32 \%)$. More than a quarter of respondents also report encountering corruption when applying for jobs (30\%), dealing with the judiciary/courts $(29 \%)$ and receiving official documents (28\%). The lowest experience of bribery is recorded for contact with the Afghan National Army (17\%) although this is still the experience of one in six respondents.

When we consider only those respondents who had contact with the institutions listed, it becomes clear that for many basic public services such as accessing health care, applying for jobs, receiving official documents and dealing with the police or the courts, in at least half of cases respondents encountered some level of corruption. These are also the services that are most frequently accessed, alongside education in which people encountered corruption in around $2 \%$ of cases. 
Table 8.7: Whenever you have contacted government officials, how often in the past year have you had to give cash, a gift or perform a favor for an official? (Q-25a-j, Base 6467)

\begin{tabular}{|l|c|c|c|c|c|c|} 
& $\begin{array}{c}\text { In all } \\
\text { cases } \\
\mathbf{( \% )}\end{array}$ & $\begin{array}{c}\text { Most } \\
\text { cases } \\
\mathbf{( \% )}\end{array}$ & $\begin{array}{c}\text { Isolated } \\
\text { Cases } \\
\mathbf{( \% )}\end{array}$ & $\begin{array}{c}\text { Bribes } \\
\text { paid } \\
\mathbf{( \% )}\end{array}$ & $\begin{array}{c}\text { No bribes } \\
\text { paid } \\
\mathbf{( \% )}\end{array}$ & $\begin{array}{c}\text { No contact } \\
\text { with of- } \\
\text { ficials } \\
\mathbf{( \% )}\end{array}$ \\
\hline Public health care service & 3 & 10 & 20 & 33 & 34 & 32 \\
\hline Afghan National Police & 3 & 10 & 19 & 32 & 32 & 36 \\
\hline When applying for a job & 3 & 11 & 16 & 30 & 28 & 40 \\
\hline Judiciary / courts & 4 & 10 & 15 & 29 & 26 & 42 \\
\hline To receive official documents & 5 & 10 & 13 & 28 & 28 & 42 \\
\hline Admissions to schools/university & 3 & 8 & 13 & 24 & 34 & 41 \\
\hline Officials in the Municipality & 3 & 7 & 12 & 22 & 28 & 49 \\
\hline State electricity supply & 2 & 7 & 13 & 22 & 30 & 46 \\
\hline Customs office & 3 & 7 & 10 & 20 & 27 & 52 \\
\hline Afghan National Army & 2 & 6 & 9 & 17 & 37 & 45 \\
\hline
\end{tabular}

Levels of corruption experienced by respondents in the different government institutions mentioned are broadly consistent with those recorded in 2009. However, the prevalence of corruption in state institutions appears to be rising over time. The experience of corruption reported by respondents in 2010 is the highest, or equivalent to the highest, for any year to date for all listed institutions except the state electricity supply where it is lower by a single percentage point. These findings help to explain why corruption is identified as the third-biggest problem facing Afghanistan (see Chapter 2, 2.4 Afghanistan's biggest problems: National level), and the second-biggest reason for pessimism amongst those who say that the country is moving in the wrong direction (see Chapter 2, 2.3 Reasons for pessimism). It also sheds light on the reasons why failure to tackle administrative corruption is identified as the most important failing of central government (see Chapter 7, 7.4 important achievements and failings of the central government).

Table 8.8: Percentage of the people who have corruption-related experience - sum of all cases, most cases and isolated cases (Q-25a-j) COMPARISON BETWEEN 2006, 2007, 2008, 2009 AND 2010

\begin{tabular}{|l|c|c|c|c|c|}
\hline & $\begin{array}{c}\mathbf{2 0 0 6} \\
\mathbf{( \% )}\end{array}$ & $\begin{array}{c}\mathbf{2 0 0 7} \\
\mathbf{( \% )}\end{array}$ & $\begin{array}{c}\mathbf{2 0 0 8} \\
\mathbf{( \% )}\end{array}$ & $\begin{array}{c}\mathbf{2 0 0 9} \\
\mathbf{( \% )}\end{array}$ & $\begin{array}{c}\mathbf{2 0 1 0} \\
\mathbf{( \% )}\end{array}$ \\
\hline To receive official documents & - & 24 & 24 & 28 & 28 \\
\hline Judiciary / courts & 35 & 23 & 23 & 29 & 29 \\
\hline When applying for a job & - & 26 & 25 & 30 & 30 \\
\hline Afghan National Police & 36 & 24 & 21 & 28 & 32 \\
\hline Public health care service & 38 & 30 & 26 & 31 & 33 \\
\hline Admissions to schools/university & - & 17 & 16 & 21 & 24 \\
\hline Officials in the Municipality & 26 & 19 & 17 & 22 & 22 \\
\hline Customs office & 20 & 12 & 14 & 17 & 20 \\
\hline State electricity supply & 24 & 22 & 17 & 23 & 22 \\
\hline Afghan National Army & - & 11 & 10 & 13 & 17
\end{tabular}




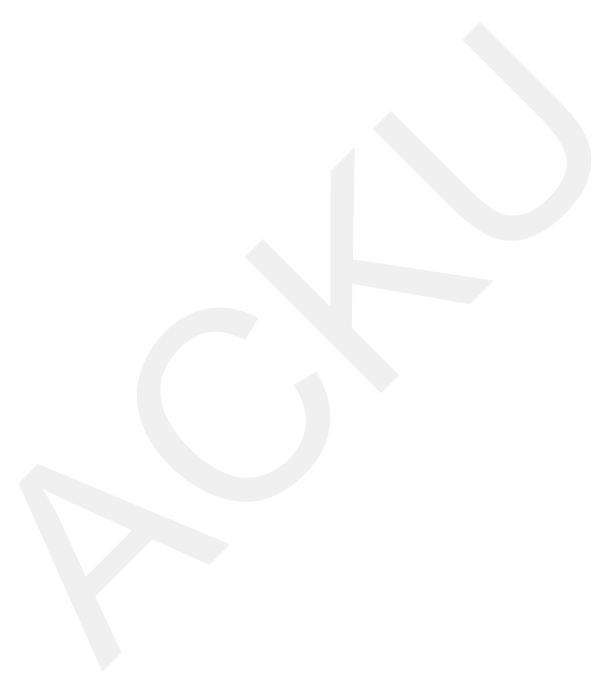




\section{Political Participation}

\subsection{Freedom of expression}

The survey endeavored to measure public opinion on freedom of expression which is one of the most important characteristics of democracy. Respondents were asked whether people feel safer, as safe as before, or less safe to freely express their opinions in their local area compared to one year ago. Twenty-five percent of respondents say they feel safer to express their opinions while another $17 \%$ say they feel less safe. Almost half $(49 \%)$ of respondents say they feel as safe as before to express their opinions.

There are, however, substantial differences between communities. A significantly higher proportion of Hazara (40\%), Uzbek (36\%) and Tajik $(30 \%)$ say they feel safer to express their opinions than do Pashtuns (15\%). Conversely, a higher proportion of Pashtuns $(23 \%)$ report that it is less safe now to express their opinions compared to one year ago in the area where they live.

There are regional differences as well. As many as half of respondents in the Central/Hazarajat region $(50 \%)$ say it is safer to freely express their opinions now. On the other hand, more than one in five respondents say it is less safe to freely express their opinions compared to one year ago in the South West (27\%), South East (21\%) and Central/Kabul (20\%) regions.

Around one in ten respondents in the West (11\%), East (10\%) and Central/Hazarajat $(9 \%)$ regions are unable or unwilling to express an opinion in this regard.

In comparison to one year ago, do people in the area where you live feel safer, as safe as before, or less safe to freely express their opinions? (Q-27, Base 6467) BY REGION

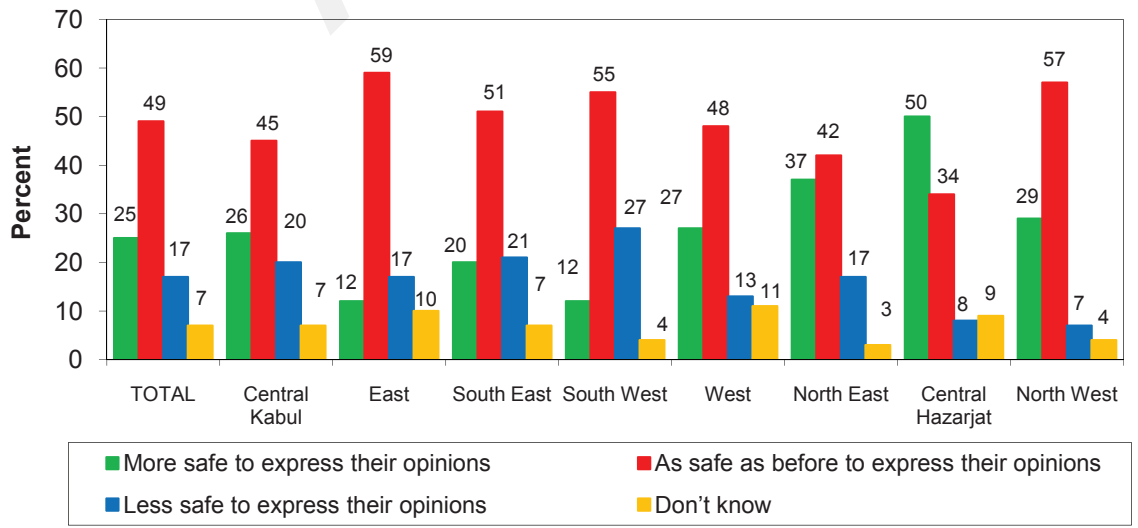

Fig 9.1 
Respondents who said that people feel safer to express their opinions in their local area (25\% of all respondents) were then asked what changes or reasons have made this possible. Respondents were invited to give two reasons. More than half $(54 \%)$ say this is because security conditions are good in their area. About a third $(32 \%)$ says this is due to the guarantee of freedom of speech. One in ten $(10 \%)$ say the reason is peace and democracy while around one in five mention people's cooperation with the government $(7 \%)$, good government $(6 \%)$ and the presence of security services such as the ANP and the ANA (6\%). Responses suggest that local security conditions and the guarantee of freedom of expression are the key factors in making people feel safer to express their opinions.

What changes compared with the past, or reasons, do you think have made most people to feel safe to express their opinions in the area where you live? (Q-28a\& combined, Base 1642)

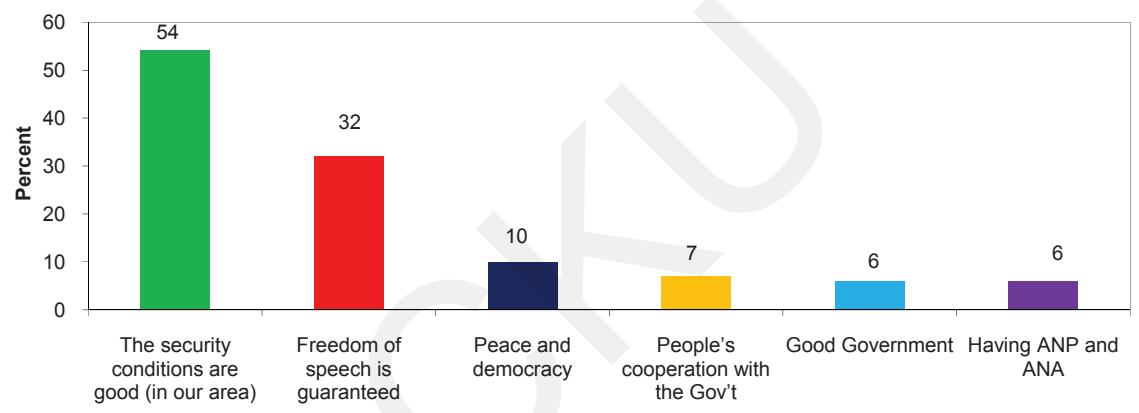

Fig 9.2

The reasons put forward by respondents follow the national pattern in all regions except the South East. A higher proportion of people cite good security conditions in the North West (69\%), North East (65\%) and Central/Hazarajat (61\%) but relatively few say the same in the South West (35\%) and South East (37\%). In the South East the highest proportion of respondents attribute improvements in freedom of expression to the fact that freedom of speech is guaranteed $(46 \%)$. 
Table 9.1: What changes compared with the past, or reasons, do you think have made most people to feel safe to express their opinions in the area where you live? (Q-28a\&b combined, Base 1642) BY REGION

\begin{tabular}{|c|c|c|c|c|c|c|c|c|c|}
\hline & $\begin{array}{l}\text { All } \\
(\%)\end{array}$ & $\begin{array}{c}\text { Central } \\
\text { /Kabul } \\
(\%)\end{array}$ & \begin{tabular}{|l|} 
East \\
$(\%)$
\end{tabular} & \begin{tabular}{|c|} 
South \\
East \\
$(\%)$
\end{tabular} & \begin{tabular}{|c|} 
South \\
West \\
$(\%)$
\end{tabular} & $\begin{array}{l}\text { West } \\
(\%)\end{array}$ & $\begin{array}{l}\text { North } \\
\text { East } \\
(\%)\end{array}$ & $\begin{array}{c}\text { Central / } \\
\text { Hazarajat } \\
(\%)\end{array}$ & \begin{tabular}{|l} 
North \\
West \\
$(\%)$
\end{tabular} \\
\hline $\begin{array}{l}\text { The security conditions } \\
\text { are good (in our area) }\end{array}$ & 54 & 47 & 41 & 37 & 35 & 47 & 65 & 61 & 69 \\
\hline $\begin{array}{l}\text { Freedom of speech is } \\
\text { guaranteed }\end{array}$ & 32 & 35 & 29 & 46 & 21 & 28 & 32 & 25 & 31 \\
\hline Peace and democracy & 10 & 11 & 9 & 20 & 8 & 7 & 6 & 11 & 9 \\
\hline $\begin{array}{l}\text { People's cooperation } \\
\text { with the Government }\end{array}$ & 7 & 5 & 13 & 9 & 5 & 5 & 9 & 3 & 6 \\
\hline Good Government & 6 & 4 & 14 & 3 & 2 & 6 & 5 & 20 & 2 \\
\hline Having ANP and ANA & 6 & 8 & 5 & 2 & 8 & 7 & 8 & 3 & 5 \\
\hline Don't know & 6 & 5 & 11 & 1 & 9 & 11 & 4 & 7 & 4 \\
\hline
\end{tabular}

Respondents who said that people feel less safe to express their opinions in their area (17\% of all respondents) were also asked why this is so. They were also invited to mention two reasons. Security issues account for the majority of responses including fear for personal safety (34\%), bad security conditions (25\%), presence of the Taliban $(24 \%)$ and presence of warlords $(6 \%)$. The absence of a guarantee of freedom of expression from the government also features prominently amongst responses $(11 \%)$. Seven percent of respondents mention the government's indifference to public opinion as a barrier to free speech. Social limitations on women's freedom of expression are also mentioned by $7 \%$ of respondents. Six percent mention the presence of warlords as the reason why people feel less free to express their political opinions.

Why don't people in your area have the freedom to express their political opinions? (Q-29a\&b combined, Base 1090)

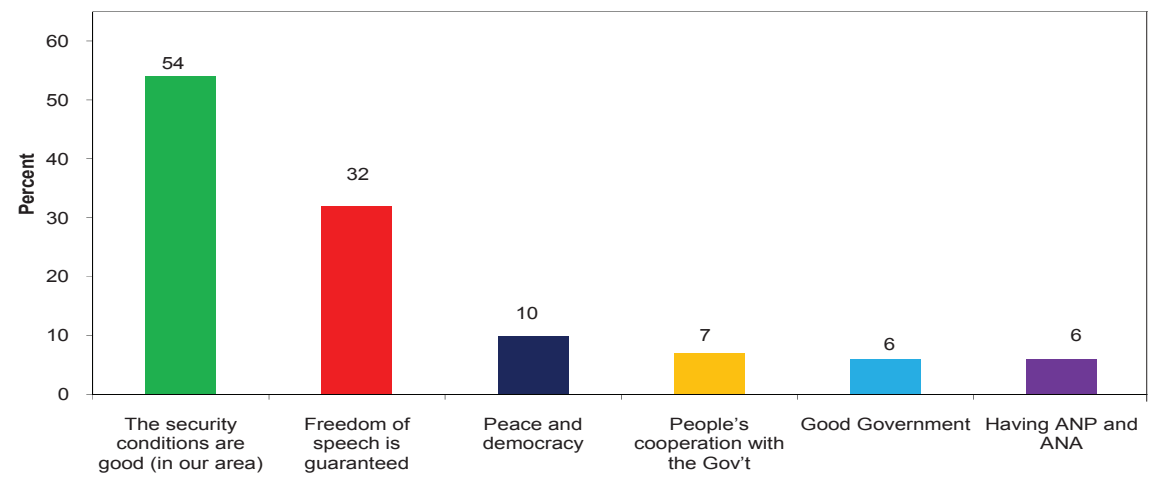

Fig 9.3 
More respondents in urban areas (43\%) say that they feel less safe to express their political opinions because of fears for personal safety than their rural counterparts (31\%). Conversely, those who indicate the presence of the Taliban as the reason for having less freedom to express their political opinions is about three times higher in rural $(28 \%)$ than urban areas $(10 \%)$.

There is variation between regions as well. The proportion of respondents who say they fear for their personal safety to freely express their political opinions is highest in the North West (48\%) and lowest in the Central/Hazarajat $(18 \%)$ region. The presence of the Taliban is mentioned most in the South East (35\%), where it is the main reason given, and in the East (28\%). The Taliban is also cited as an impediment to freedom of expression by a little under a quarter of respondents in all the other regions except the North West $(12 \%)$ and the Central/Hazarajat $(6 \%)$.

Government prohibition of freedom of political expression is identified by about four times more respondents in the North West (23\%) and twice as many in the Central/Hazarajat (17\%) and South East (16\%) compared to the West (6\%), South West $(8 \%)$ and East $(9 \%)$. Lack of education is also mentioned by four times as many respondents in the Central/Hazarajat $(12 \%)$ and twice as many in the West $(6 \%)$ and Central/Kabul (5\%) as in other regions.

Other issues which are identified only in specific regions include the lack of real democracy $(10 \%)$ and fear of coalition forces $(5 \%)$ in the South East, ethnic discrimination in the North East (5\%) and lack of awareness of legal rights in the Central/Hazarajat region (6\%). In the Central/Hazarajat more than one-third of respondents $(36 \%)$ and one in seven in the West $(14 \%$ are unable or unwilling to answer this question.

Table 9.2: Why don't people in your area have the freedom to express their political opinions? (Q-29a\&b combined, Base 1090) BY REGION

\begin{tabular}{|c|c|c|c|c|c|c|c|c|c|}
\hline & $\begin{array}{l}\text { All } \\
(\%)\end{array}$ & $\begin{array}{c}\text { Central/ } \\
\text { Kabul } \\
(\%)\end{array}$ & $\begin{array}{l}\text { East } \\
(\%)\end{array}$ & $\begin{array}{c}\text { South } \\
\text { East } \\
(\%)\end{array}$ & \begin{tabular}{|c} 
South \\
West \\
$(\%)$
\end{tabular} & $\begin{array}{l}\text { West } \\
(\%)\end{array}$ & $\begin{array}{c}\text { North } \\
\text { East } \\
(\%)\end{array}$ & $\begin{array}{c}\text { Central/ } \\
\text { Hazarajat } \\
(\%)\end{array}$ & $\begin{array}{c}\text { North } \\
\text { West } \\
(\%)\end{array}$ \\
\hline Fear for personal safety & 34 & 39 & 34 & 30 & 27 & 25 & 37 & 18 & 48 \\
\hline $\begin{array}{l}\text { Security conditions are bad in } \\
\text { this area }\end{array}$ & 25 & 19 & 37 & 28 & 32 & 19 & 26 & 12 & 18 \\
\hline Presence of Taliban & 24 & 24 & 28 & 35 & 22 & 23 & 22 & 6 & 12 \\
\hline $\begin{array}{l}\text { The Government doesn't allow } \\
\text { freedom of political opinion }\end{array}$ & 11 & 12 & 9 & 16 & 8 & 6 & 11 & 17 & 23 \\
\hline Don't know & 8 & 9 & 6 & 1 & 8 & 14 & 9 & 36 & 3 \\
\hline $\begin{array}{l}\text { Women are under the control } \\
\text { of men }\end{array}$ & 7 & 8 & 6 & 4 & 7 & 4 & 9 & 11 & 13 \\
\hline $\begin{array}{l}\text { The Government doesn't care } \\
\text { about people's opinion }\end{array}$ & 7 & 5 & 5 & 5 & 7 & 8 & 10 & 12 & 8 \\
\hline Presence of warlords & 6 & 6 & 2 & 2 & 9 & 15 & 4 & 0 & 1 \\
\hline
\end{tabular}


The proportion of respondents who identify fear for their safety as the reason for lack of freedom of expression in their area has been basically stable at $34 \%$ since 2007, except for a spike in 2008 (41\%). The proportion mentioning poor local security conditions has been falling since 2006 (from 40\% to 36\% in 2007, 38\% in 2008, 29\% in 2009) and is lower in 2010 (25\%) than in any previous year, although this finding is likely to be affected by the increased restrictions on the movement of survey researchers in insecure areas in 2010 (see Chapter 1, 1.3 Restriction on survey field work and replacement of sampling points for security reasons). The proportion of respondents who explicitly mention a threat from the Taliban has fluctuated substantially since 2006, but has risen in 2010 (24\%) compared to 2009 (21\%) and 2008 $(18 \%)$, whereas those who mention the presence of warlords continues to fall (from $32 \%$ in 2006 to $18 \%$ in $2007,8 \%$ in $2008,7 \%$ in 2009 and $6 \%$ in 2010 ).

The proportion of respondents who mention government prohibition of freedom of political expression in $2010(11 \%)$ is almost the same as in 2009 (12\%). This figure has fallen from $15 \%$ in $2008,22 \%$ in 2007 and $17 \%$ in 2006.

Those mentioning women being under the control of men as a reason for limited freedom of expression have declined slightly in 2010 (7\%) compared to 2009 (9\%) and $2008(10 \%)$ however, this is still almost double the figure recorded in $2006(4 \%)$ and $2007(4 \%)$.

The proportion of respondents who are unwilling or unable to answer this question has doubled in $2010(8 \%)$ compared to previous years.

Table 9.3: Why don't people in your area have the freedom to express theirpolitical opinions? (Q29a\&sb combined) COMPARISON BETWEEN 2006, 2007, 2008, 2009 AND 2010

\begin{tabular}{|l|c|c|c|c|c|} 
& $\begin{array}{c}\mathbf{2 0 0 6} \\
\mathbf{( \% )}\end{array}$ & $\begin{array}{c}\mathbf{2 0 0 7} \\
\mathbf{( \% )}\end{array}$ & $\begin{array}{c}\mathbf{2 0 0 8} \\
\mathbf{( \% )}\end{array}$ & $\begin{array}{c}\mathbf{2 0 0 9} \\
\mathbf{( \% )}\end{array}$ & $\begin{array}{c}\mathbf{2 0 1 0} \\
\mathbf{( \% )}\end{array}$ \\
\hline Fear for safety & 30 & 34 & 41 & 34 & 34 \\
\hline $\begin{array}{l}\text { Security conditions are bad } \\
\text { Presence of Taliban }\end{array}$ & $\mathbf{4 0}$ & 36 & 38 & 29 & 25 \\
\hline Presence of warlords & 33 & 18 & 8 & 7 & 6 \\
\hline $\begin{array}{l}\text { Government not allow freedom of politi- } \\
\text { cal opinions }\end{array}$ & 17 & 22 & 15 & 12 & 11 \\
\hline $\begin{array}{l}\text { Women are under the control of men } \\
\text { Don't Know }\end{array}$ & 4 & 4 & 10 & 9 & 7 \\
\hline
\end{tabular}




\subsection{Personal Efficacy: ability to influence government decisions}

The survey attempted to measure perceptions of personal efficacy in political participation. Personal efficacy refers to the degree of influence people think someone like them can have over government decisions through participation in political processes, both formal and informal. More than half (54\%) of respondents say they feel they can have a significant degree of influence over government decisions, including $(12 \%)$ who say a lot of influence and $42 \%$ saying some influence. Around a quarter $(24 \%)$ say they cannot have any influence at all.

How much influence do you think someone like you can have over government decisions? (Q-30, Base 6467)

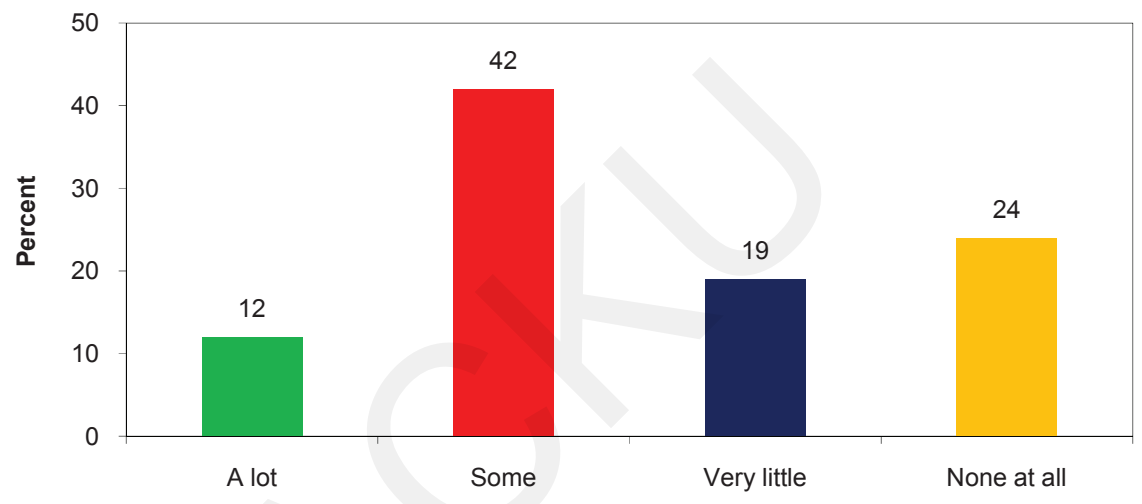

Fig 9.4

More than half $(55 \%)$ of respondents in rural areas say they can influence government decision making to some degree compared to just under half of their urban counterparts (47\%). However, there is no significant difference between men $(54 \%)$ and women $(53 \%)$ in this regard.

The highest levels of confidence in the ability to influence government decisions are recorded in the East $(74 \%)$ where almost three quarters of respondents say they can have some level of influence, followed by the North East (60\%) and the North West (58\%). These are also the regions that report the highest levels of satisfaction with government performance, (see Chapter 7, 7.2 Satisfaction with the performance of the central government and 7.3 Satisfaction with central government performance in policy and service delivery) and the highest proportion of respondents who think the country is going to right direction (see Chapter 2, 2.1 Direction of the country). This could suggest that when government is perceived to be meeting the needs of communities, people feel that their participation in political processes is able to make a difference. 
Conversely, more than half of respondents in the Central/Hazarajat (52\%), South East (51\%) and Central/Kabul (51\%) regions say they have little or no ability to influence government decisions, including more than a third in the Central/Hazarajat $(37 \%)$ and Central/Kabul (34\%) regions who say they can have 'no influence at all.'

How much influence do you think someone like you can have over government decisions? (Q-30, Base 6467) BY REGION

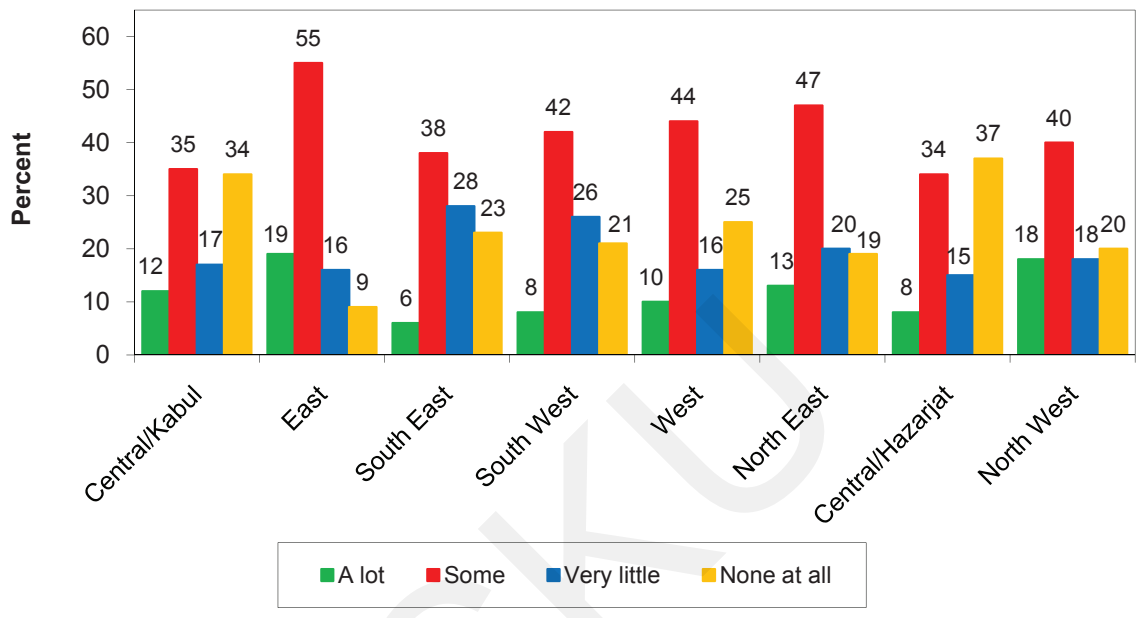

Fig 9.5

The results of the 2010 survey are similar to those recorded in previous years. However, they do show some small but significant trends. The proportion of respondents who say they can have some influence over government decisions has been rising steadily (from $36 \%$ in 2006 to $42 \%$ in 2010 ).

However, the proportions of respondents who say they can have very little influence or no influence at all have also been rising since 2008, although they still remain lower than in 2006 and 2007. These figures have risen significantly in 2010 in the Central/Hazarajat (from 31\% in 2009 to $52 \%$ in 2010) and Central/Kabul region (from $37 \%$ in 2009 to $51 \%$ in 2010 ). 
How much influence do you think someone like you can have over government decisions? (Q-30) COMPARISON BETWEEN 2006, 2007, 2008, 2009 AND 2010

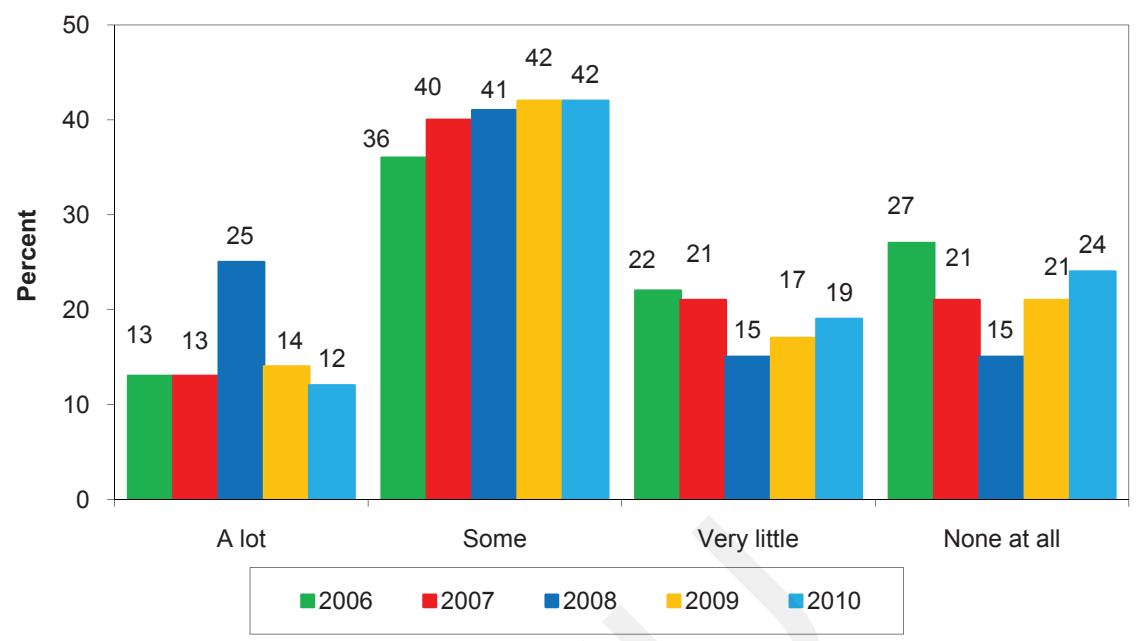

Fig 9.6

\subsection{Satisfaction with elected representatives}

In order to measure the levels of satisfaction of the Afghan people with their elected representatives, the survey asked all respondents how satisfied or dissatisfied they are with their Members of Parliament (MPs). Nearly two thirds (64\%) of respondents say they are satisfied with their MP, including $18 \%$ who say they are very satisfied and $46 \%$ who say they are somewhat satisfied. However, the remaining third of respondents $(33 \%)$ are dissatisfied with their representatives, including $13 \%$ who say they are very dissatisfied.

In general how satisfied or dissatisfied you are with your MP representing you in the Parliament? (Q-31, Base 6467)

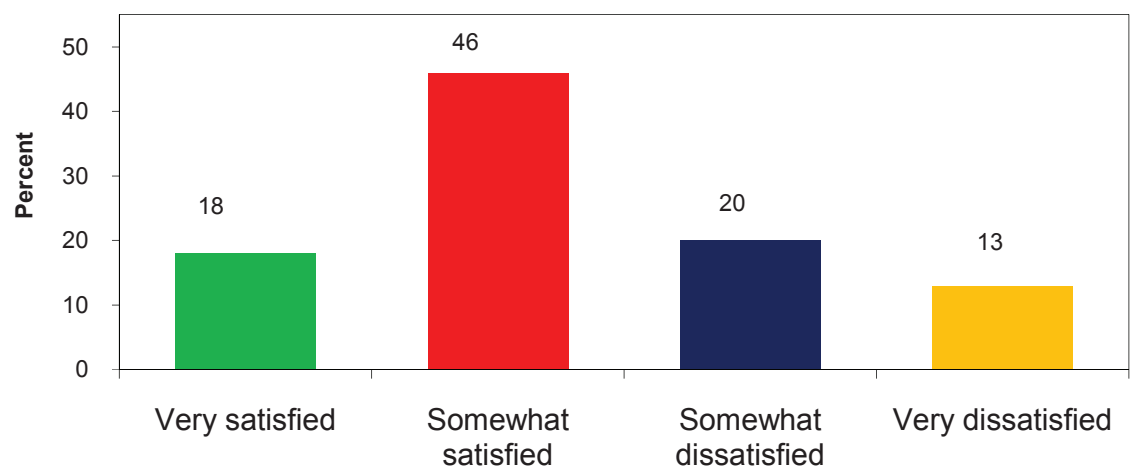

Fig 9.7 
Levels of satisfaction are highest in the North West (75\%) and East (73\%) where around three quarters of respondents are very or somewhat satisfied with the MP representing them in parliament. About two-thirds of respondents are also satisfied with their MP in the North East (68\%), West (66\%) and Central/Hazarajat (65\%) regions. Again, with the exception of the Central/Hazarajat, these regions record the highest levels of satisfaction with the performance of central government (see Chapter 7, 7.2 Satisfaction with the performance of the central government) and amongst the highest levels of satisfaction with government service provision (see Chapter 7, 7.3 Satisfaction with central government performance in policy and service delivery), suggesting that perceptions of the performance of individual MPs and perceptions of the performance of government generally are closely associated. The exception to this is the Central/Hazarajat region which records amongst the lowest levels of satisfaction with central government performance across all domains, but a high level of satisfaction with the performance of local MPs.

In contrast, almost half of respondents in the South West (45\%) and South East $(43 \%)$ are somewhat or very dissatisfied with their MP representing them in parliament. The South East also records particularly low levels of satisfaction with government performance in the provision of basic services (see Chapter 7, 7.3 Satisfaction with central government performance in policy and service delivery).

In general how satisfied or dissatisfied you are with your MP representing you in the Parliament? (Q-31, Base 6467) BY REGION

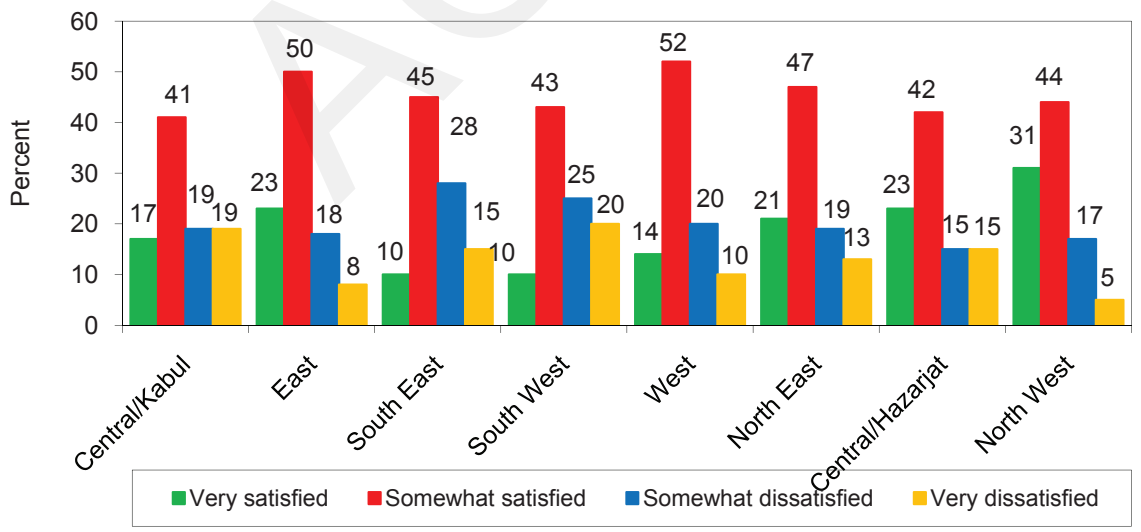

Fig 9.8

In addition, the survey sought to ascertain how useful respondents think the parliament is in general. Two-thirds of respondents (67\%) say parliament is useful, including $30 \%$ who say it is very useful and $37 \%$ saying quite useful. Around a third $(32 \%)$ says parliament is not useful, including $12 \%$ who say it is not useful at all. 
Now tell me, in your opinion, how useful is the parliament in general? (Q-32, Base 6467)

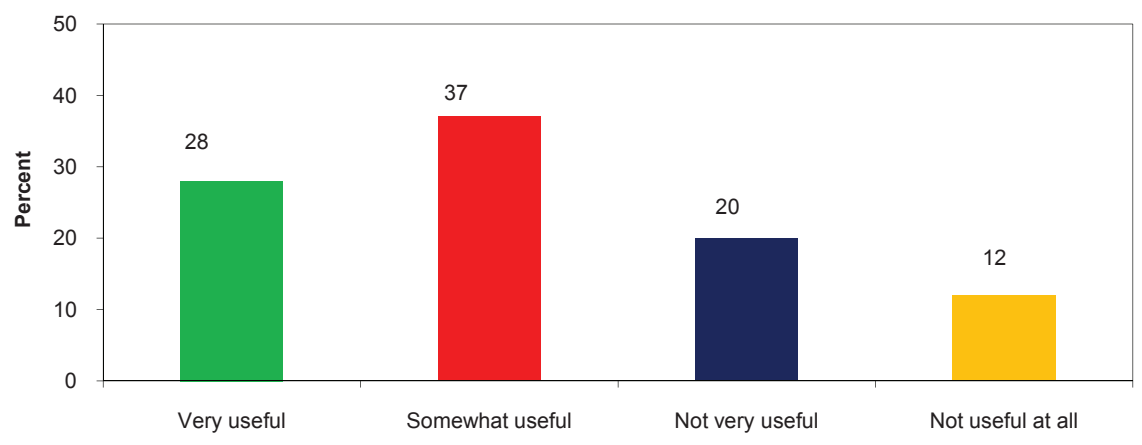

Fig 9.9

There is significant variation between regions in perceptions of the usefulness of parliament. Four-fifths of respondents in the East (80\%), and three quarters in the North West $(75 \%)$ and Central/Hazarajat (76\%) regions say that parliament is very or somewhat useful. This is also the case for two-thirds in the North East $(69 \%)$ and Central/Kabul (64\%) regions. However, this is true for barely half of respondents in the South West $(52 \%)$.

How much useful - a lot/very useful, somewhat, very little, or not useful at all - the parliament is in general? (Q-32, Base-6467) BY REGION

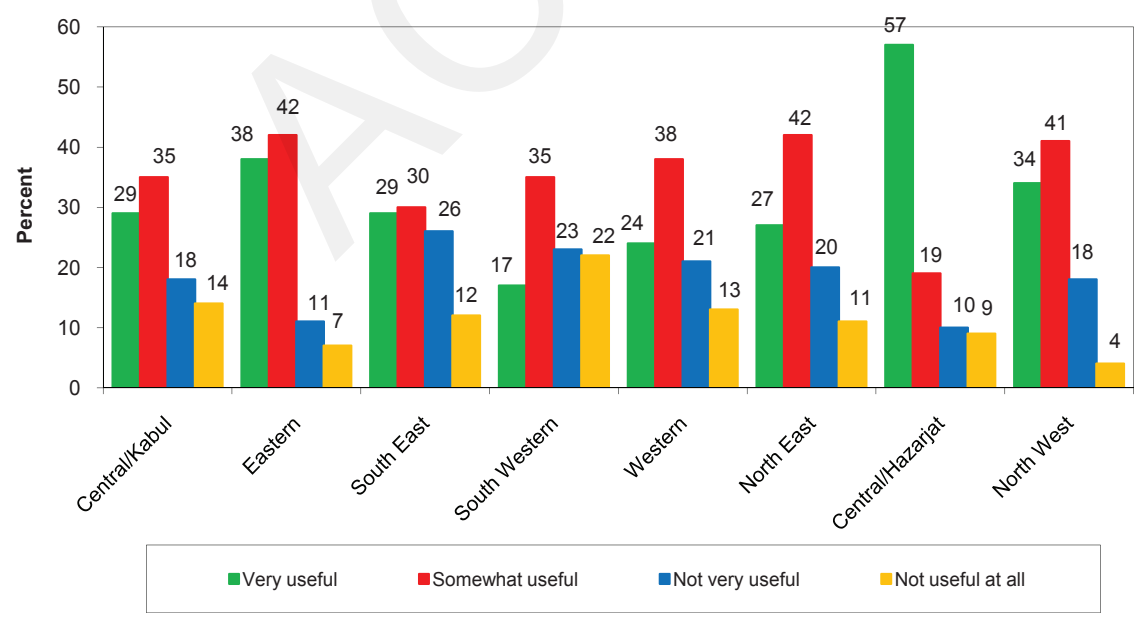

Fig 9.10

\subsection{Consideration of the public interest when making decisions and policies}

The survey also sought to examine public perceptions of whether various institu- 
tions consider the public interest or their own interests when they make decisions and policies. The following table summarizes the findings.

Table 9.4: Do you think the following institutions consider the Afghan Public interests, their own interests or more or less both when making decisions and policies? (Q-33a-e, Base 6467)

\begin{tabular}{|l|c|c|c|} 
& $\begin{array}{c}\text { Afghans' interests } \\
(\mathbf{\%})\end{array}$ & $\begin{array}{c}\text { Their own interests } \\
\mathbf{( \% )}\end{array}$ & $\begin{array}{c}\text { Both } \\
(\mathbf{\%})\end{array}$ \\
\hline Government & 46 & 30 & 22 \\
\hline Parliament & 27 & 44 & 27 \\
\hline Court & 26 & 49 & 23 \\
\hline NGOs & 19 & 53 & 25 \\
\hline Donors & 17 & 50 & 26 \\
\hline
\end{tabular}

Nearly half of respondents $(46 \%)$ say the government considers interests of the Afghan public when making decisions and policies. The government is the only organization of those listed that more respondents believe makes decisions in the public interest as opposed to its own interests. This is consistent with the finding that two-thirds of respondents are satisfied with the way the national government is carrying out its responsibilities (see Chapter 7, 7.2: Overall rating of the national government). Just under half of respondents in rural areas (49\%) compared to one-third of urban dwellers (35\%) think that the government considers the public interest most,

By contrast, more respondents think that parliament considers its own interests (44\%) rather than the interests of the Afghan public (27\%). This is the same for the courts, which almost half of respondents think consider their own interests $(49 \%)$ while just over a quarter (26\%) say they consider the public interest.

The majority of respondents think that NGOs (53\%) and donors (50\%) consider their own interests first when making decisions and policies. However, about one quarter $(25 \%)$ say that they consider both the public interest and their own interests.

At the regional level, around two-thirds of respondents in the East (64\%) and over half in the South West (53\%) say the government considers the Afghan public's interests. On the other hand more than a third of respondents in the South West (36\%) and Central/Kabul (36\%) regions also say that the government looks after its own interests first. Views are most polarized in the South West and the East where less than one in ten respondents think that the government considers both their own as well as the public's interest. 
Table 9.5a: Do you think the following institutions consider the Afghan Public interests, their own interests, or more or less both when making decisions and policies? (Q-33a-e, Base 6467)BY REGION

\begin{tabular}{|c|c|c|c|c|c|c|c|c|c|}
\hline Government & $\begin{array}{l}\text { All } \\
(\%)\end{array}$ & $\begin{array}{c}\text { Central/ } \\
\text { Kabul } \\
(\%)\end{array}$ & $\begin{array}{l}\text { East } \\
(\%)\end{array}$ & $\begin{array}{c}\text { South } \\
\text { East } \\
(\%)\end{array}$ & \begin{tabular}{|c|} 
South \\
West \\
$(\%)$
\end{tabular} & $\begin{array}{l}\text { West } \\
(\%)\end{array}$ & $\begin{array}{c}\text { North } \\
\text { East } \\
(\%)\end{array}$ & $\begin{array}{c}\text { Central / } \\
\text { Hazarajat } \\
(\%)\end{array}$ & \begin{tabular}{|c} 
North \\
West \\
$(\%)$
\end{tabular} \\
\hline Afghans Interests & 46 & 35 & 64 & 48 & 53 & 44 & 46 & 23 & 52 \\
\hline Their Own Interests & 30 & 36 & 25 & 28 & 36 & 29 & 31 & 27 & 19 \\
\hline Both more or less & 22 & 27 & 10 & 22 & 9 & 25 & 22 & 46 & 26 \\
\hline
\end{tabular}

Although nationally just under half (49\%) of respondents think the courts pursue their own interests first, the majority of respondents in the Central/Kabul (57\%), South East (53\%) and West (52\%) believe this to be true. On the other hand, a high proportion in the East (43\%) and around a third in the North East $(32 \%)$ believe the courts look after Afghan's interests.

Table 9.5b:

\begin{tabular}{|c|c|c|c|c|c|c|c|c|c|}
\hline Court & $\begin{array}{l}\text { All } \\
(\%)\end{array}$ & $\begin{array}{c}\text { Central/ } \\
\text { Kabul } \\
(\%)\end{array}$ & $\begin{array}{l}\text { East } \\
(\%)\end{array}$ & $\begin{array}{c}\text { South } \\
\text { East } \\
(\%)\end{array}$ & $\begin{array}{c}\text { South } \\
\text { West } \\
(\%)\end{array}$ & $\begin{array}{l}\text { West } \\
(\%)\end{array}$ & $\begin{array}{c}\text { North } \\
\text { East } \\
(\%)\end{array}$ & $\begin{array}{c}\text { Central / } \\
\text { Hazarajat } \\
(\%)\end{array}$ & $\begin{array}{c}\text { North } \\
\text { West } \\
(\%)\end{array}$ \\
\hline Afghans Interests & 26 & 19 & 43 & 21 & 24 & 24 & 32 & 16 & 25 \\
\hline $\begin{array}{l}\text { Their Own In- } \\
\text { terests }\end{array}$ & 49 & 57 & 41 & 53 & 46 & 52 & 48 & 43 & 40 \\
\hline Both more or less & 23 & 21 & 15 & 25 & 27 & 20 & 19 & 36 & 31 \\
\hline
\end{tabular}

In all regions, more respondents say that parliament looks after its own interests rather than the interests of the Afghan public, with the exception of the North West where opinion is equally divided. The majority of respondents in the Central/ Kabul (52\%) and South West (52\%) regions hold this opinion. Again, the highest proportion of respondents who think parliament considers the public interests first is found in the East (37\%) and North West (30\%). This is consistent with these regions' high levels of satisfaction with the performance of their local MP (see above, 9.3 Satisfaction with elected representatives) and with the performance of central government (see Chapter 7, 7.3 Satisfaction with central government performance in policy and service delivery). 
Table 9.5c:

\begin{tabular}{|c|c|c|c|c|c|c|c|c|c|}
\hline Parliament & $\begin{array}{l}\text { All } \\
(\%)\end{array}$ & $\begin{array}{c}\text { Central/ } \\
\text { Kabul } \\
(\%)\end{array}$ & $\begin{array}{l}\text { East } \\
(\%)\end{array}$ & $\begin{array}{c}\text { South } \\
\text { East } \\
(\%)\end{array}$ & $\begin{array}{c}\text { South } \\
\text { West } \\
(\%)\end{array}$ & $\begin{array}{l}\text { West } \\
(\%)\end{array}$ & $\begin{array}{c}\text { North } \\
\text { East } \\
(\%)\end{array}$ & $\begin{array}{c}\text { Central / } \\
\text { Hazarajat } \\
(\%)\end{array}$ & \begin{tabular}{|c|} 
North \\
West \\
$(\%)$
\end{tabular} \\
\hline Afghans Interests & 27 & 21 & 37 & 27 & 25 & 27 & 26 & 21 & 30 \\
\hline Their Own Interests & 44 & 52 & 40 & 42 & 52 & 46 & 44 & 31 & 30 \\
\hline Both more or less & 27 & 25 & 21 & 28 & 20 & 23 & 28 & 41 & 36 \\
\hline
\end{tabular}

Nationally, NGOs are the institutions that most respondents think take care of their own interests rather than the interests of the Afghan public. This is true at a regional level as well. About two-thirds of respondents in the Central/Kabul (63\%) region and more than half in the North East (56\%), West (52\%) and South West $(52 \%)$ think that NGOs consider their own interests when making decisions and policies. On the other hand, a third of respondents in the East (33\%) and almost a quarter in the South East (23\%) think NGOs consider the Afghan public interest.

Table 9.5d:

\begin{tabular}{|c|c|c|c|c|c|c|c|c|c|}
\hline NGOs & $\begin{array}{l}\text { All } \\
(\%)\end{array}$ & $\begin{array}{c}\text { Central/ } \\
\text { Kabul } \\
(\%)\end{array}$ & $\begin{array}{l}\text { East } \\
(\%)\end{array}$ & $\begin{array}{c}\text { South } \\
\text { East } \\
(\%)\end{array}$ & $\begin{array}{c}\text { South } \\
\text { West } \\
(\%)\end{array}$ & $\begin{array}{l}\text { West } \\
(\%)\end{array}$ & $\begin{array}{c}\text { North } \\
\text { East } \\
(\%)\end{array}$ & $\begin{array}{c}\text { Central / } \\
\text { Hazarajat } \\
(\%)\end{array}$ & $\begin{array}{c}\text { North } \\
\text { West } \\
(\%)\end{array}$ \\
\hline Afghans Interests & 19 & 13 & 33 & 23 & 19 & 17 & 15 & 15 & 19 \\
\hline Their Own Interests & 53 & 63 & 48 & 41 & 52 & 52 & 56 & 45 & 48 \\
\hline Both more or less & 25 & 20 & 19 & 33 & 25 & 22 & 27 & 33 & 29 \\
\hline
\end{tabular}

Although nationally half of respondents (50\%) think donors consider their own interests first when making decisions and policies, higher proportions say this in the Central/Kabul (60\%) and South West (56\%) than in other regions. Again the perception that donors consider the public interest first is highest in the East $(27 \%)$ followed by the North West (23\%). 


\begin{tabular}{|c|c|c|c|c|c|c|c|c|c|}
\hline Donors & $\begin{array}{l}\text { All } \\
(\%)\end{array}$ & $\begin{array}{c}\text { Central/ } \\
\text { Kabul } \\
(\%)\end{array}$ & $\begin{array}{l}\text { East } \\
(\%)\end{array}$ & $\begin{array}{c}\text { South } \\
\text { East } \\
(\%)\end{array}$ & $\begin{array}{c}\text { South } \\
\text { West } \\
(\%)\end{array}$ & $\begin{array}{c}\text { West } \\
(\%)\end{array}$ & $\begin{array}{c}\text { North } \\
\text { East } \\
(\%)\end{array}$ & $\begin{array}{c}\text { Central / } \\
\text { Hazarajat } \\
(\%)\end{array}$ & $\begin{array}{l}\text { North } \\
\text { West } \\
(\%)\end{array}$ \\
\hline Afghans Interests & 17 & 14 & 27 & 19 & 12 & 15 & 15 & 13 & 23 \\
\hline Their Own Interests & 50 & 60 & 45 & 41 & 56 & 48 & 50 & 42 & 42 \\
\hline Both more or less & 26 & 21 & 25 & 33 & 23 & 21 & 29 & 33 & 30 \\
\hline
\end{tabular}

\subsection{Democratic spirit of the government}

The survey attempted to explore perceptions of the commitment of the Afghan government to core democratic principles. Respondents were asked if they agree or disagree with a number of statements related to the application of such principles. The first statement was: "I don't think the government cares much about what people like me think." Around three quarters of respondents (74\%) agree with this statement, including $30 \%$ who strongly agree. Only $24 \%$ disagree with the statement.

Eight out of ten respondents in the East (83\%) agree and the same is true for about three quarters in the South East (78\%), North West $(77 \%)$, West $(76 \%)$, Central/Kabul (75\%) and North East (74\%). However, less than two-thirds of respondents agree with this statement in the South West (65\%) and Central/ Hazarajat $(63 \%)$ regions.

Do you agree with «I don't think that the government cares much about what people like me think.» (Q-12a, Base-6467) BY REGION

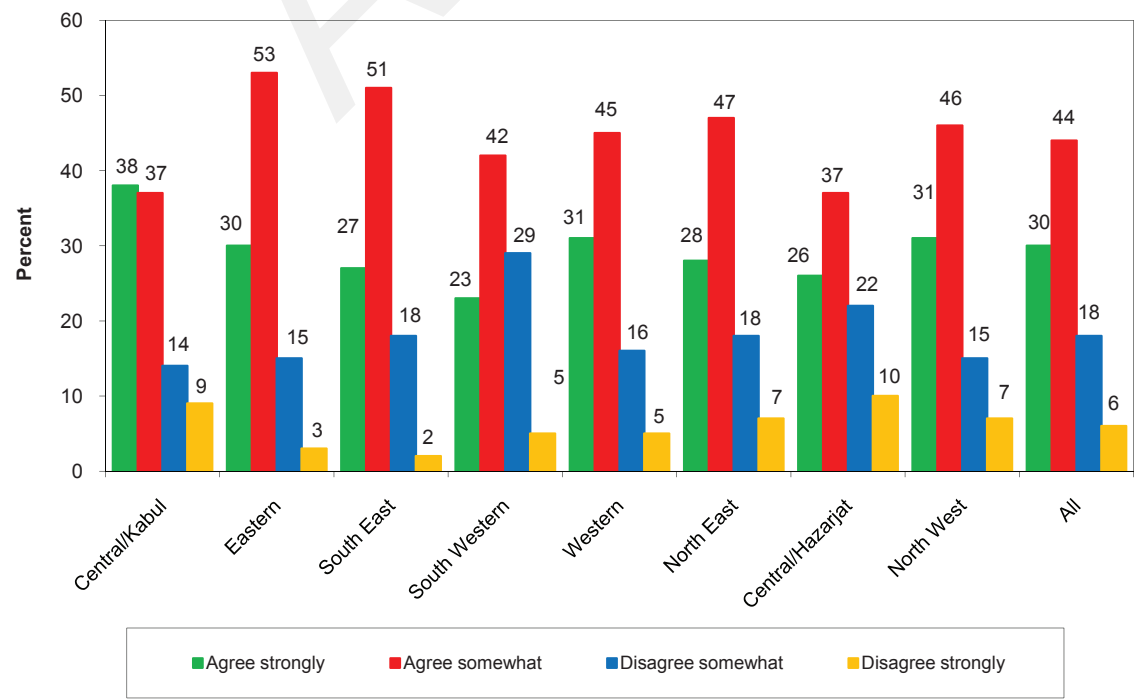

Fig 9.11 
The second statement was: "It is generally not acceptable to talk negatively about the Government in public." Sixty-two percent of respondents agree with this statement, including 23\% who strongly agree. Over one-third (36\%) disagree.

More than 60 percent of respondents agree that it is not acceptable to criticize the government in the East (69\%), Central/Kabul (65\%), West (64\%), North East $(63 \%)$ and North West (62\%) regions. A higher proportion of residents in the South West $(48 \%)$ and South East $(40 \%)$ say it is acceptable to talk negatively about the government than in other regions.

Do you agree with «It is generally not acceptable to talk negatively about the government in public»? (Q-12b, Base All respondents 6467) BY REGION

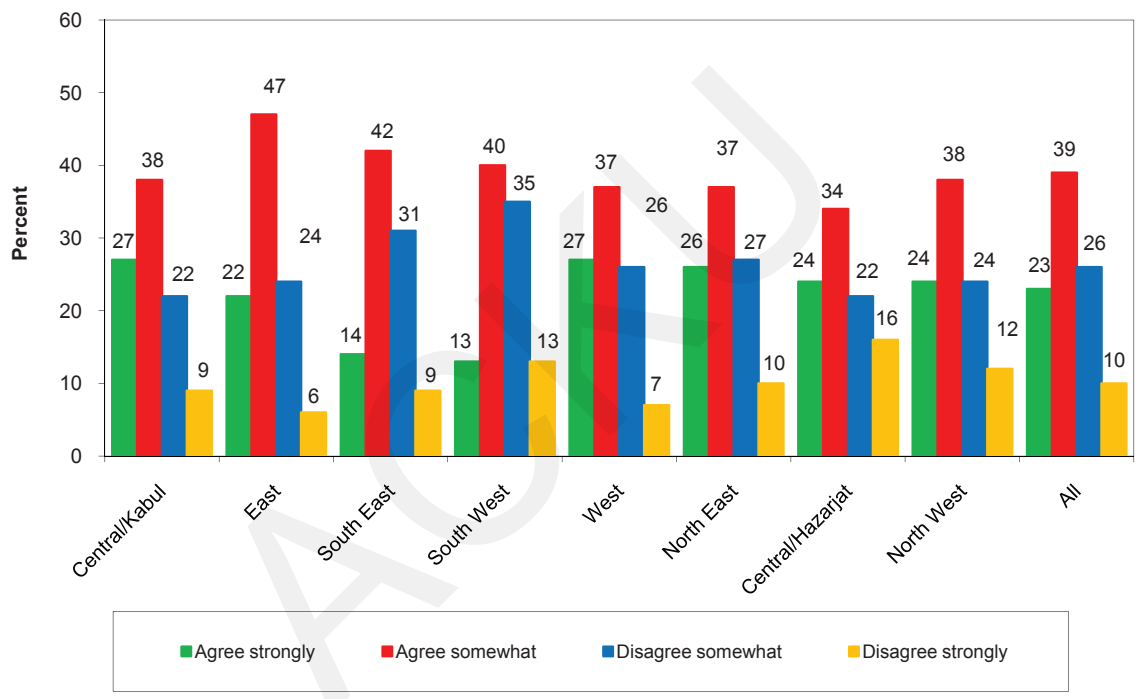

Fig 9.12

Respondent's views on a further set of statements were also assessed. The first of these was: "It is a good thing that the government should allow peaceful opposition." More than four out of five respondents (83\%) agree with this statement.

However, levels of support for this statement vary between regions. Public support for allowing peaceful opposition is highest in the East $(88 \%)$, North West $(88 \%)$, Central/Kabul (86\%), North East and Western (81\%) regions, and lowest in the Central/Hazarajat (70\%). Around one in five respondents disagree that the government should allow peaceful opposition in the Central/Hazarajat $(23 \%)$ followed by the South West (21\%) and South East (19\%). 
Please tell me if you agree with the statement "It is a good thing that the government should allow peaceful opposition》 (Q41a, Base All Respondents 6467) BY REGION AND ALL

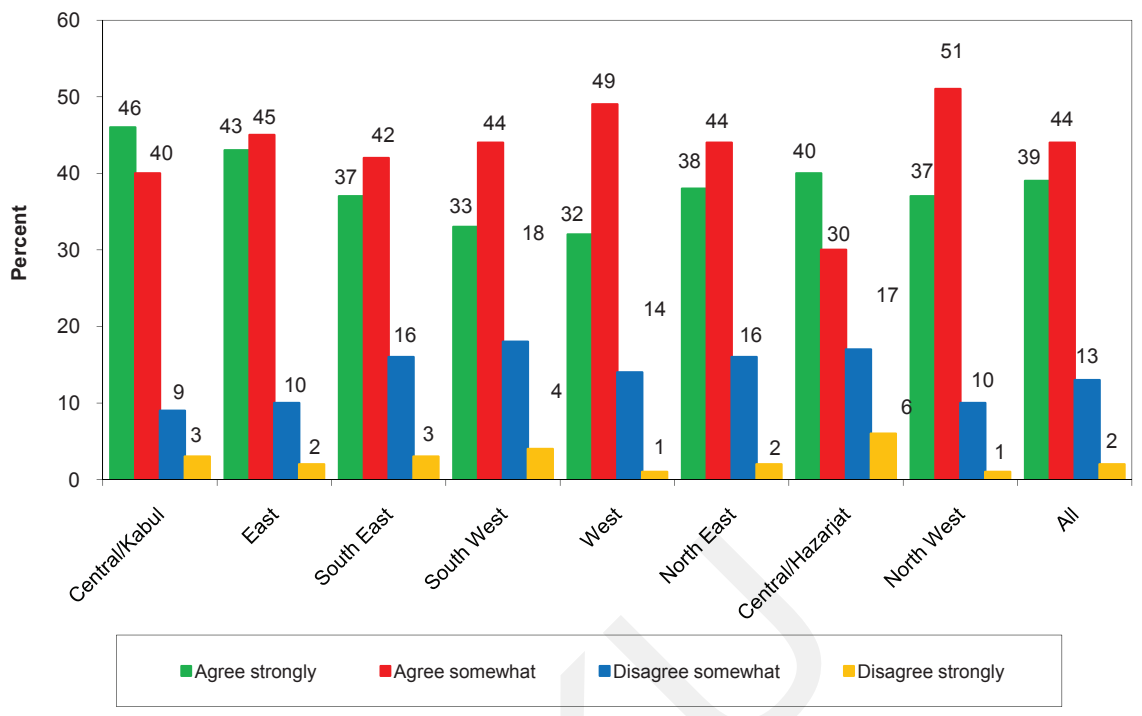

Fig 9.13

The second statement was: "Everyone should have equal rights under the law, regardless of their gender, ethnicity, or religion." A similarly high proportion (81\%) agrees with this statement.

There are, however, differences in views between ethnic groups. More than fourfifths of Hazara (88\%), Uzbek (89\%), Tajik (80\%) and respondents of other ethnicities $(81 \%)$ agree with this statement, compared to just over three quarters of Pashtuns $(77 \%)$. Examined regionally, more than four-fifths of respondents agree with this statement in the Central/Hazarajat (90\%) North East (87\%), Central/Kabul (87\%), South East (84\%) and North West (82\%), compared to just over two-thirds in the South West (68\%). On the other hand, $32 \%$ of respondents in the South West, $29 \%$ in West and 20\% in the East disagree that everyone should have equal rights under the law, 
Please tell me if you agree with "Everyone should have equal rights under the law, regardless of their gender, ethnicity or religion》 (Q41b, Base All Respondents 6467) ALL AND BY REGION

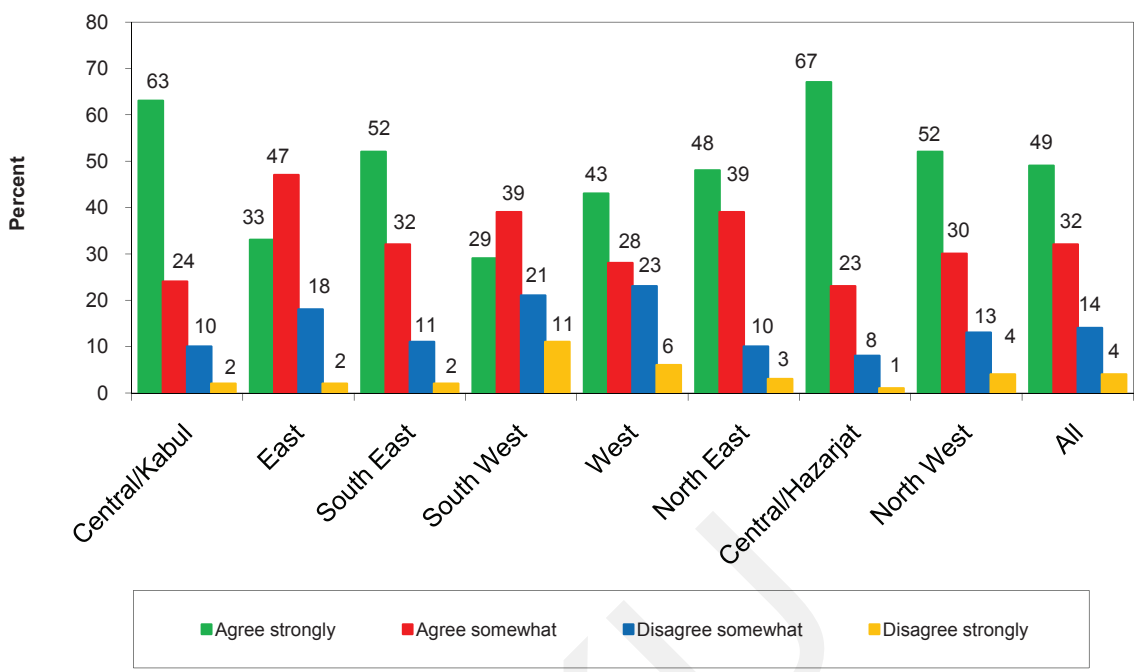

Fig 9.14

Agreement with the principle of equal rights remained stable in 2010 compared to 2009, but does not reverse the declining trend which has been evident since 2006 (from 90\% in 2006 and 2007 to $84 \%$ in 2008, 80\% in 2009 and $81 \%$ in 2010).

However, levels of support for allowing peaceful opposition rose significantly in 2010 to $83 \%$ after falling consistently from 2006 (84\%) to 81\% in 2007, $78 \%$ in 2008 and $77 \%$ in 2009. This appears to be consistent with the increased number of peaceful demonstrations held across the country in the last year, particularly in the capital Kabul.

Over time there have been only small fluctuations in the proportion of respondents who say that the government does not care about the views of people like them. This is also true for those who say it is unacceptable to talk negatively about the government, which has remained stable for the last three years. 
Table 9.6: Proportion of those who agree (combination of strongly agree and agree somewhat) toward the statements related to democratic spirit of the government (Q-12a-b and Q41a-b)) COMPARISON BETWEEN 2006, 2007, 2008, 2009 AND 2010

\begin{tabular}{|l|c|c|c|c|c|} 
& $\begin{array}{c}2006 \\
(\%)\end{array}$ & $\begin{array}{c}2007 \\
(\%)\end{array}$ & $\begin{array}{c}\mathbf{2 0 0 8} \\
\mathbf{( \% )}\end{array}$ & $\begin{array}{c}\mathbf{2 0 0 9} \\
\mathbf{( \% )}\end{array}$ & $\begin{array}{c}\mathbf{2 0 1 0} \\
\mathbf{( \% )}\end{array}$ \\
\hline $\begin{array}{l}\text { I don't think that the government cares } \\
\text { much about what people like me think }\end{array}$ & 77 & 79 & 76 & 74 & 74 \\
\hline $\begin{array}{l}\text { It is generally not acceptable to talk negatively } \\
\text { about the Government in public }\end{array}$ & - & 69 & 62 & 61 & 62 \\
\hline $\begin{array}{l}\text { It is a good thing that the government } \\
\text { should allow peaceful opposition }\end{array}$ & 84 & 81 & 78 & 77 & 83 \\
\hline $\begin{array}{l}\text { Everyone should have equal rights under } \\
\text { the law, regardless of their gender, ethnicity } \\
\text { or religion }\end{array}$ & 90 & 90 & 84 & 80 & 81 \\
\hline
\end{tabular}

\subsection{Attitudes toward participation in democratic processes}

The survey also sought respondent's views on the principles that guide their own participation in democratic processes. They were asked to what extent they agree or disagree with the statement: A person should vote the way his or her community votes, not how they feel individually. More than half of respondents (57\%) say they agree with this statement, while $41 \%$ say that voting should be a matter of individual choice.

However, levels of agreement with this statement vary significantly between regions. Over two-thirds of respondents agree that people should vote the way the community votes in the East (69\%), South East (65\%), and North West (62\%), whereas more than half of respondents in the North East (53\%) and at least $30 \%$ in all other regions disagree. 
Please tell me if you agree with "A person should vote the way his or her community votes, not how they feel individually"(Q41c, Base All Respondents 6467) BY REGION AND ALL

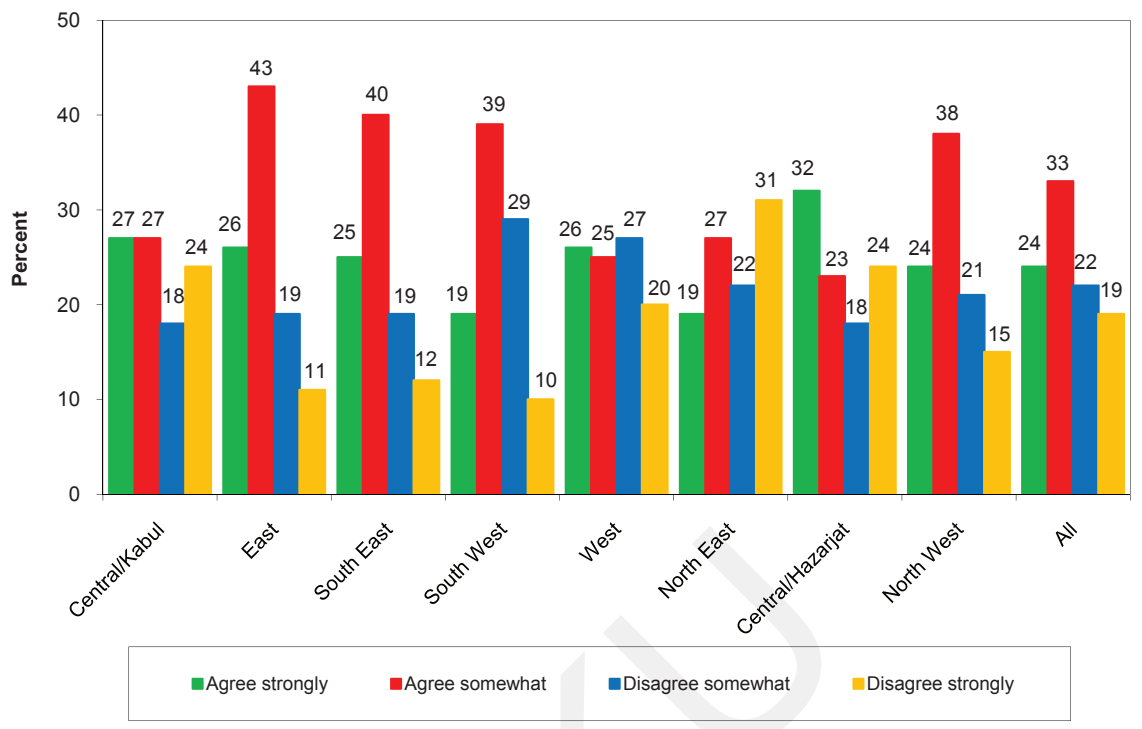

Fig 9.15

Over time there has been the proportion of respondents who agree with the statement: "a person should vote the way his or her community votes, not how they feel individually" has been falling (from 65\% in 2008 to 59\% in 2009 and 57\% in 2010).

Table 9.7: Public agreement (combination of strongly agree and agree somewhat) with various democratic principles (Q-41-c) COMPARISON BETWEEN 2008, 2009 AND 2010

\begin{tabular}{|l|c|c|c|}
\hline $\begin{array}{l}2008 \\
(\%)\end{array}$ & $\begin{array}{c}2009 \\
(\%)\end{array}$ & $\begin{array}{c}2010 \\
(\%)\end{array}$ \\
\hline $\begin{array}{l}\text { c) A person should vote the way his or her } \\
\text { community votes, not how they feel individually }\end{array}$ & 65 & 59 & 57 \\
\hline
\end{tabular}

\subsection{Awareness of the parliamentary elections}

The survey, which was administered in May and June of 2010, sought to measure public awareness regarding the parliamentary elections in Afghanistan scheduled for September 2010. Respondents were first asked if they were aware of the upcoming parliamentary elections. Just over three quarters (78\%) said they were aware, but around one in five $(20 \%)$ said they were not. Levels of awareness were higher among men $(83 \%)$ than women $(72 \%)$. 
Are you aware of the upcoming parliamentary elections in Afghanistan? (Q-46, Base 6467) ALL AND BY GENDER

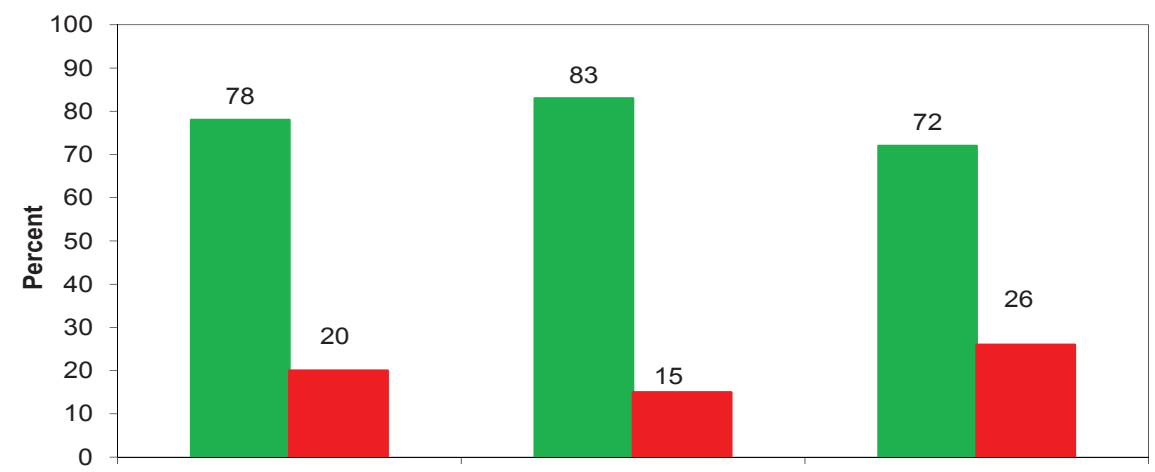

Fig. 9.16

Awareness of the upcoming parliamentary elections in 2010 was lower (78\%) than the level of awareness for the same period regarding the planned presidential elections in 2009 (85\%), and significantly lower than in 2004 when the first presidential elections were held, when over nine in ten respondents $(91 \%)$ had heard that elections were coming. ${ }^{4}$

Are you aware of the upcoming parliamentary elections in Afghanistan? (Q-46) ALL AND BY GENDER, COMPARISON 2004, 2009, 2010

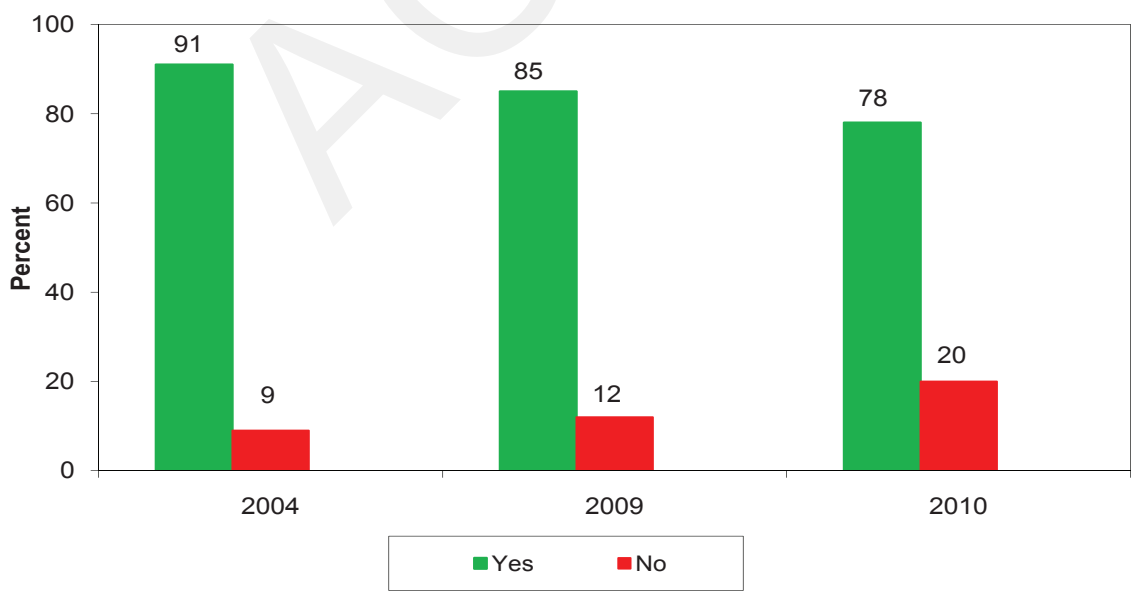

Fig. 9.17

4 The Asia Foundation ran its first Afghan public opinion survey in 2004 with a specific focus on voter education in relation to the 2004 Presidential elections. The survey was much smaller in scope covering a population sample of 804 citizens 18 or older living in the country. It was conducted in 29 of Afghanistan's then 32 provinces. See VOTER EDUCATION PLANNING SURVEY: Afghanistan 2004 National Elections A REPORT BASED ON A PUBLIC OPINION POLL. The Asia Foundation, Kabul, July 2004. 
There was marked variation in the level of awareness across regions. More than four-fifths of respondents in the East (85\%), South East (84\%), North East (81\%) and South West (80\%) reported being aware of the elections, in contrast to just over two-thirds in the Central/Hazarajat (68\%) and just under three quarters in the Central $/ \mathrm{Kabul}(73 \%)$ regions.

The lower levels of awareness of the upcoming elections in the Central/Hazarajat compared to other regions may be influenced by the fact that this regions records amongst the lowest levels of radio and television ownership in the country (see Chapter 12,12.1 Access to communication technology), meaning that their access to the most commonly used sources of information on the elections was more limited (see below 9.8 Information about the upcoming elections).

Are you aware of the upcoming parliamentary elections in Afghanistan? (Q-46, Base 6467,) BY REGION

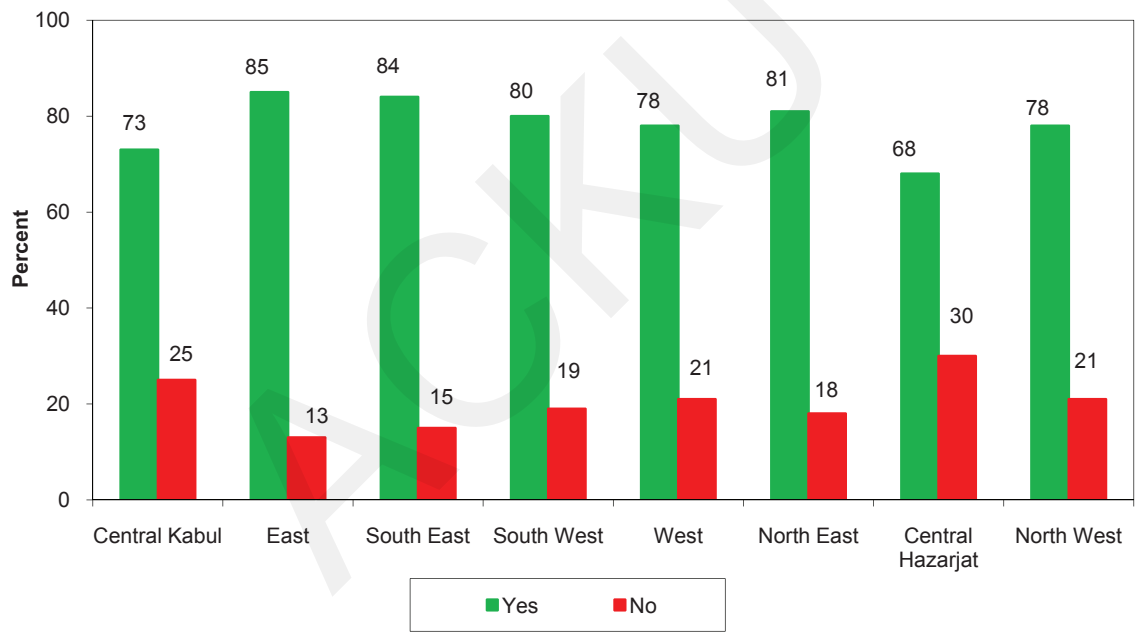

Fig 9.18

\subsection{Information about the upcoming elections}

Respondents who were aware of the elections (78\% of all respondents) were then asked to identify their main source of electoral information. The most commonly mentioned source of information was radio (46\%) followed by television (26\%) and friends, family and neighbors (14\%). This finding is largely similar to that for information sources regarding the 2009 presidential and provincial council elections. It is also consistent with information access in general, as almost identical proportions of respondents say they use radio (46\%) and television (28\%) to access information on news and current events (see Chapter 12, 12.2 Radio listenership and 12.3 Television viewership). 
However, there are significant differences between regions regarding respondent's main source of information about the elections. Radio is the most frequently mentioned source of information about elections in all regions except the Central/Kabul and Central/Hazarajat. The main source of information on the upcoming parliamentary elections in the Central/Kabul region is television (51\%), while friends and families are the main source of information about elections in the Central/Hazarajat (34\%). Regional differences are likely to be largely determined by access to different media (see Chapter 12, 12.1 Access to communications technology).

(Filtered) What was your main source of information about the elections? (Q-47, Base- 5072)

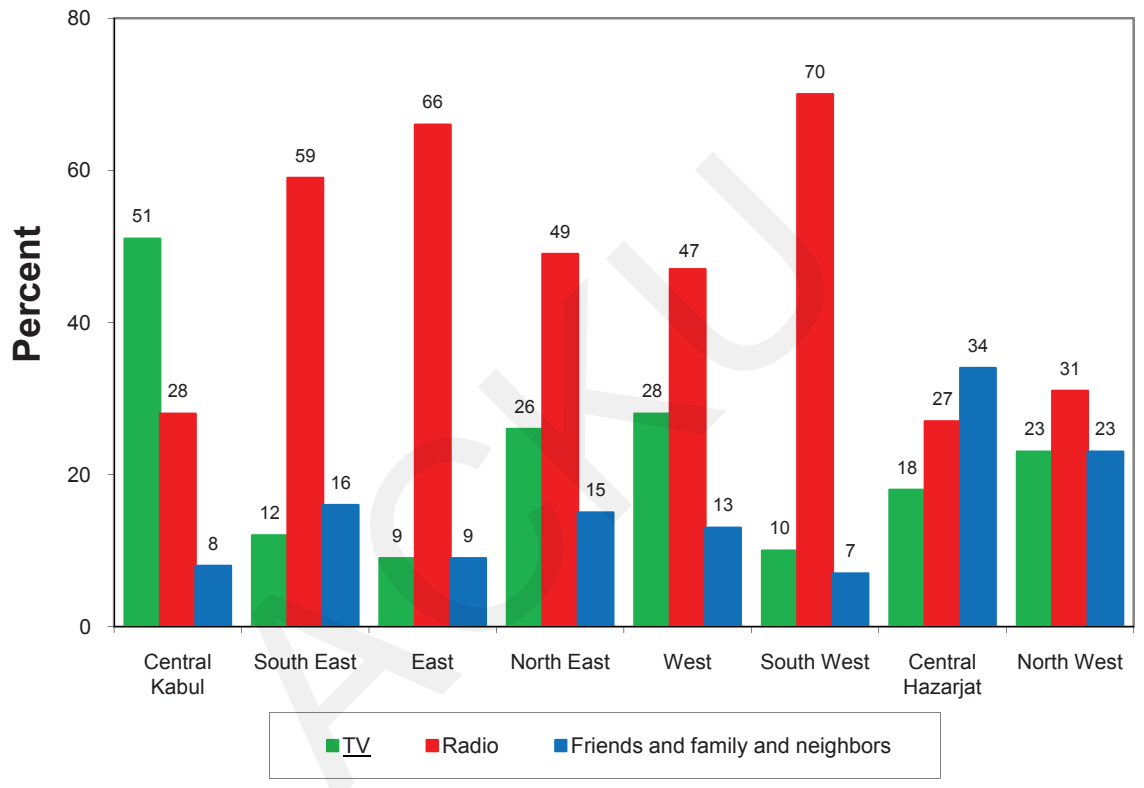

Fig. 9.19

\subsection{Intention to vote in the $\mathbf{2 0 1 0}$ parliamentary elections}

All respondents, regardless of whether they had been previously aware about the elections or not, were asked how likely they were to vote in the coming parliamentary elections. Three quarters (74\%) said that they were likely to vote, including $39 \%$ who said this was very likely. However, about one in four (23\%) said they were unlikely to vote, including $12 \%$ who said this was very unlikely. 
How likely are you to vote in the coming parliamentary elections? (Q-48, Base 6467)

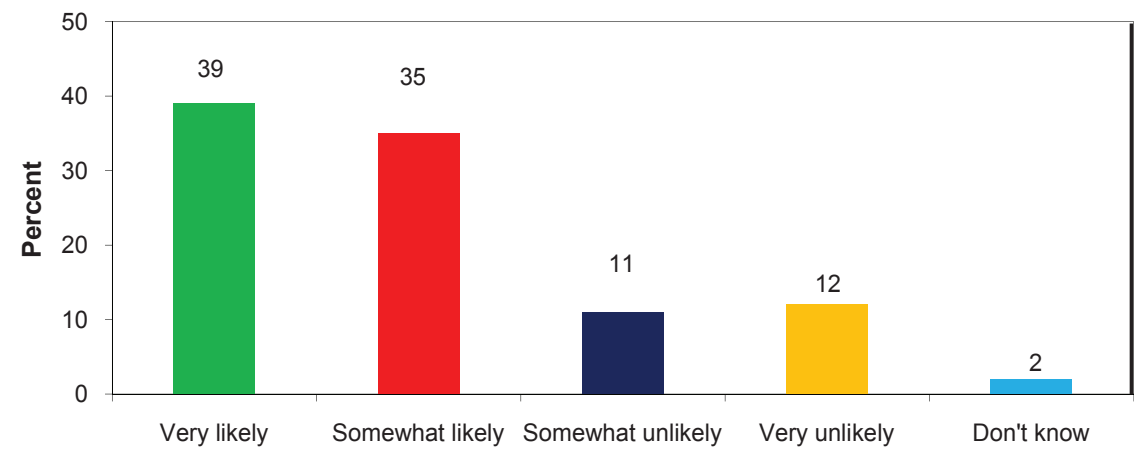

Fig. 9.20

The proportion of respondents who said they intended to vote in 2010 (74\%) was similar to that recorded for the presidential elections in 2009 (73\%), although in 2009 almost half of respondents $(48 \%)$ said they were very likely to vote, whereas only $39 \%$ said this in 2010. However theses figures were lower than for the 2004 election when $81 \%$ of respondents said they intended to exercise their right to vote.

Table 9.8: How likely are you to vote in the coming parliamentary elections? Comparison 2004, 2009, (Presidential Elections) and 2010 (Q-48)

\begin{tabular}{|l|c|c|c|} 
& $\begin{array}{c}\mathbf{2 0 0 4} \\
\mathbf{( \% )}\end{array}$ & $\begin{array}{c}\mathbf{2 0 0 9} \\
\mathbf{( \% )}\end{array}$ & $\begin{array}{c}\mathbf{2 0 1 0} \\
\mathbf{( \% )}\end{array}$ \\
\hline More likely & 81 & 73 & 74 \\
\hline Less likely & 10 & 20 & 23 \\
\hline Don't know & 9 & 5 & 2 \\
\hline
\end{tabular}

Preliminary estimates indicate that voting intention reported by survey respondents in 2010 was significantly higher than actual electoral participation, as in previous years. Although in the 2004 survey $81 \%$ of respondents said they intended to vote, the turnout in the 2004 presidential election was estimated to be 8.1 million people, which was $70 \%$ of registered voters, including those out of the country in Iran \& Pakistan. In 2009, turnout was estimated at 5.6 million of the country's 15 million registered voters, and then reduced to 4.5 million after audit, representing a turnout of around $30 \% \%^{5}$. This was significantly lower than the $73 \%$ of 2009 survey respondents who had said they were likely to vote, and even than the $48 \%$ who said they were very likely to vote in the presidential elections. Very preliminary figures for 
the 2010 parliamentary election suggest a turnout of 4 to 4.5 million, equivalent to approximately $40 \%$ of eligible Afghan voters, which is again much lower than the $74 \%$ intended participation indicated by survey respondents three months prior to the elections ${ }^{6}$.

There is a variance between men and women in terms of electoral participation: While $79 \%$ of men said they were somewhat or very likely to vote in the upcoming parliamentary election, only $70 \%$ of women said so. However, there was little difference between urban $(75 \%)$ and rural $(74 \%)$ respondents.

Though the majority of respondents in all regions said they were likely to vote in the parliamentary elections, significantly higher proportions said this in the Central Hazarajat (91\%), North West (88\%), East (79\%), North East (79\%), West $(77 \%)$, and Central/ Kabul (71\%), than in South East (65\%) and South West (57\%).

Respondents who said they were somewhat or very unlikely to vote in the parliamentary elections ( $23 \%$ of all respondents) were asked to give their reasons. The main reasons mentioned were insecurity $(22 \%)$, not interested $(21 \%)$, fear of intimidation $(12 \%)$, don't have a registration card $(10 \%)$, elections wouldn't make a difference (9\%), will not be permitted to vote $(7 \%)$ and don't support any party $(5 \%)$.

You said it is somewhat or very unlikely that you would vote in the upcoming elections. Why do you say that? (Q-49, Base 1502)

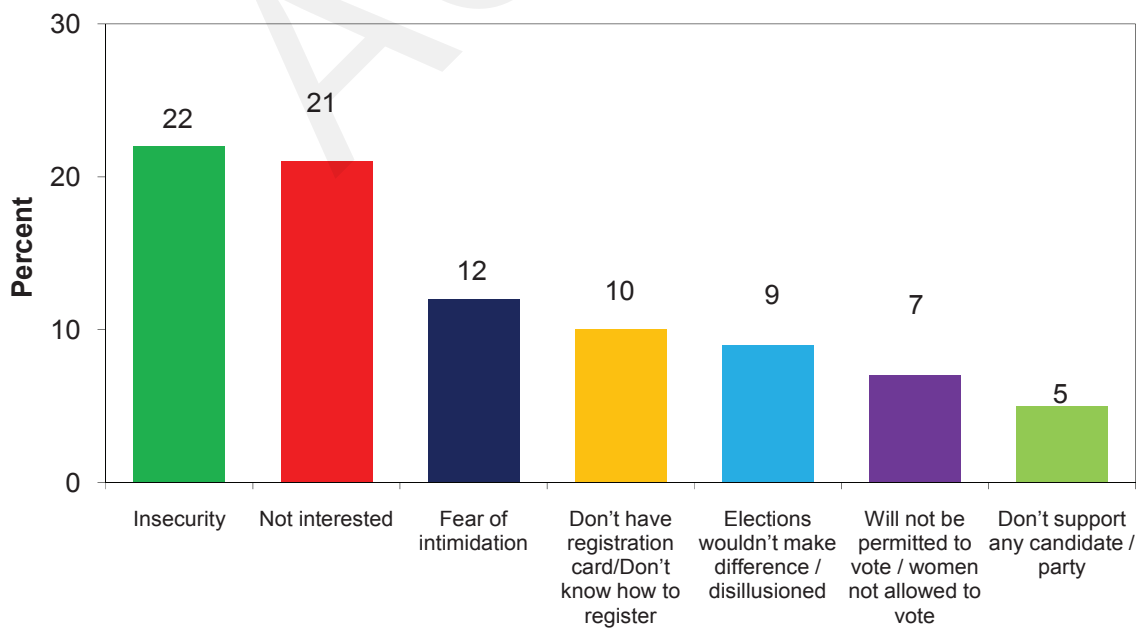

Fig.9.21 
In the South West and South East, which recorded the highest proportions of respondents who did not intend to vote, insecurity was the most frequently mentioned reason, identified by $30 \%$ of those not intending to vote. This was also the most common reason identified in the East (31\%), and Central/Hazarajat (26\%) regions. Lack of interest in the elections was the most frequently cited reason in the North West (32\%), North East (24\%), West (22\%) and Central/Kabul (21\%) regions.

Table 9.9: You said it is somewhat or very unlikely that you would vote in the upcoming elections. Why do you say that? (Q-49, Base 1502)

\begin{tabular}{|c|c|c|c|c|c|c|c|c|}
\hline & $\begin{array}{c}\text { Central / } \\
\text { Kabul } \\
(\%)\end{array}$ & $\begin{array}{l}\text { East } \\
(\%)\end{array}$ & $\begin{array}{c}\text { South } \\
\text { East } \\
(\%)\end{array}$ & \begin{tabular}{|c|} 
South \\
West \\
$(\%)$
\end{tabular} & $\begin{array}{l}\text { West } \\
(\%)\end{array}$ & $\begin{array}{l}\text { North } \\
\text { East } \\
(\%)\end{array}$ & $\begin{array}{c}\text { Central / } \\
\text { Hazarajat } \\
(\%)\end{array}$ & $\begin{array}{c}\text { North } \\
\text { West } \\
(\%)\end{array}$ \\
\hline Not interested & 21 & 20 & 17 & 20 & 22 & 24 & 8 & 32 \\
\hline $\begin{array}{l}\text { Elections wouldn't make } \\
\text { difference / disillusioned }\end{array}$ & 9 & 8 & 12 & 8 & 7 & 14 & 16 & 6 \\
\hline Fear of intimidation & 6 & 12 & 21 & 13 & 14 & 9 & 0 & 10 \\
\hline Insecurity & 13 & 31 & 30 & 30 & 19 & 18 & 26 & 14 \\
\hline $\begin{array}{l}\text { Will not be permitted to vote / } \\
\text { women not allowed to vote }\end{array}$ & 14 & 8 & 3 & 4 & 3 & 10 & 9 & 5 \\
\hline $\begin{array}{l}\text { Don't have registration card/ } \\
\text { Don't know how to register }\end{array}$ & 18 & 5 & 9 & 3 & 15 & 4 & 8 & 10 \\
\hline Don't know & 8 & 7 & 2 & 7 & 9 & 9 & 17 & 12 \\
\hline
\end{tabular}

Insecurity was the most frequently identified reason for not voting in the parliamentary elections in rural areas $(25 \%)$, whereas in urban areas the main reason identified was lack of interest $(27 \%)$.

Around one in seven of the women who did not intend to vote $(14 \%)$ reported that this was because they «will not be permitted to vote.» However this is much lower than in 2009 when $26 \%$ of the women who did not intend to vote gave this reason and in 2004 when $23 \%$ said the same.

The proportion of respondents who reported having no interest in the elections as their reason for not voting is lower in 2010 (21\%) than it was in 2009 (26\%). However it is still significantly higher than during the first presidential elections in 2004 $(10 \%)$ and in $2006(12 \%)$ following the last parliamentary elections (held in 2005).

Respondents who said they were likely to vote in the upcoming elections (74\% of all respondents) were then asked about the most important reason why they wanted to vote. More than a quarter $(28 \%)$ of respondents said it was because it is their right to vote, and $5 \%$ mentioned that it is their obligation as a citizen. Another $23 \%$ said that they would vote because it brings peace, and $6 \%$ said because it brings prosperity and reconstruction. Around one in ten mentioned that they would vote to choose their leaders $(12 \%)$ or because it would help the country $(10 \%)$. 
What is the most important reason why you want to vote? (Q-50, Base 4833)

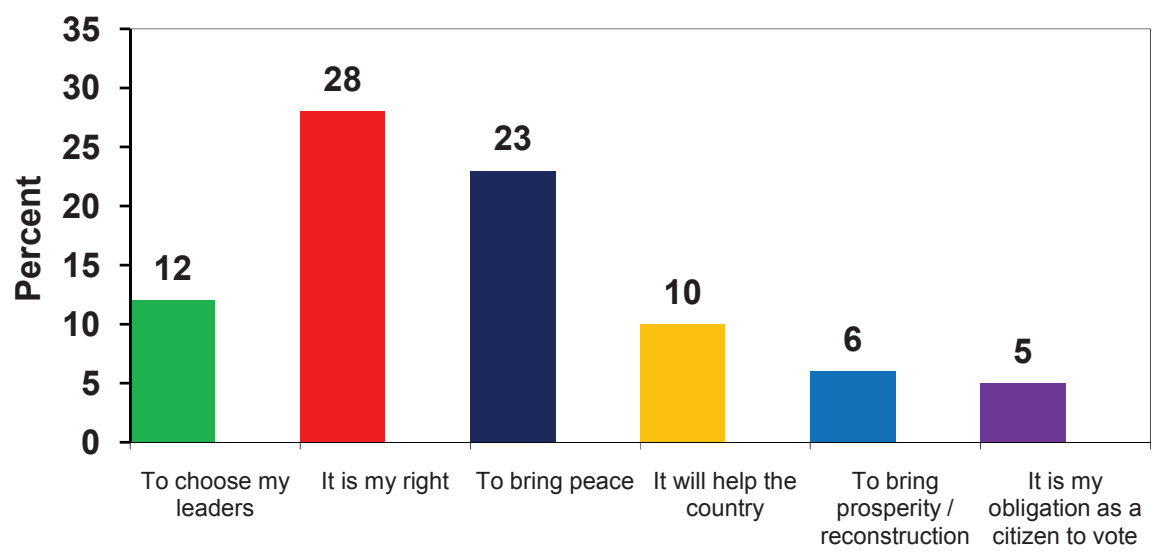

Fig.9.22

\subsection{Perceptions of the $\mathbf{2 0 0 9}$ presidential elections}

Respondents were asked whether they thought the 2009 presidential elections were free and fair. Before asking this question, respondents were briefed about what the terms 'free' and 'fair' mean in this regard. In an electoral context 'free' means that all people have the chance to vote as they wish. 'Fair' means that all candidates and parties follow the rules and are given equal access to public channels of communication, and votes are counted correctly and not manipulated.

Over half $(54 \%)$ of respondents say that the past presidential elections were free and fair, while more than a third $(38 \%)$ say they were not. Perceptions of the presidential elections differ significantly from the expectations expressed by respondents in 2009 before $t$ he elections were held. At that time nearly two-thirds (64\%) of respondents said they expected the 2009 presidential elections to be free and fair, while only around a fifth $(22 \%)$ expected they would not. However these results were in stark contrast to the expectations expressed before the first presidential elections in 2004 when three-fifths of those surveyed (60\%) said they did not know whether the coming elections would be free and fair. Of those who expressed an opinion, 37\% thought the elections would be fair and $4 \%$ thought they would not. These findings could suggest that while the first round of elections in 2004 and 2005 seem to have established Afghan's confidence in well-conducted election processes, the experience of the 2009 presidential elections, which were marred by accusations of fraud and threats of violence, may have diminished this confidence in the quality of the electoral process.

Though the majority of respondents from all the ethnic communities in Afghanistan think the past presidential elections were free and fair, a higher proportion of Uzbeks (70\%) think this than Hazara (56\%), Pashtun (53\%) and Tajik (49\%) respondents. 
Perceptions differ across the regions as well. While around two-thirds of respondents in the East (69\%) and North West (67\%), and a majority in the Central/Hazarajat (60\%), North East (57\%) and Central/Kabul (51\%) regions say that the 2009 presidential elections were free and fair. This is true for less than half of respondents in the South East (48\%), South West (46\%) and West (41\%). At least one in ten respondents was unwilling or unable to answer this question in the West $(16 \%)$, Central Hazarajat (11\%) and South Western (10\%) regions.

\section{Do you think the past presidential election was free and fair? (Q-51, Base 6467) BY REGION}

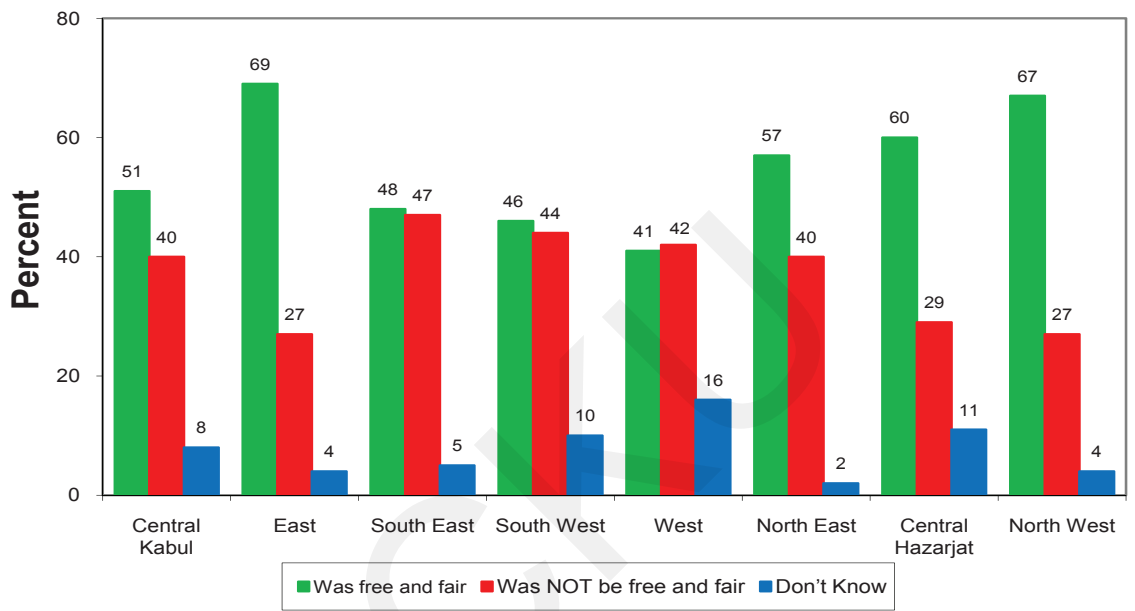

Fig. 9.23

Respondents who said that the 2009 presidential elections were not free and fair (38\% of all respondents) were then asked why, in their view, this was the case. The most common reason identified was cheating in the vote count $(40 \%)$ while another third $(33 \%)$ of respondents identified buying of votes. Irregularities in vote counting were cited by at least $40 \%$ of respondents in the Central/Kabul (44\%), Central/ Hazarajat (43\%), North West (41\%), East (41\%) and South East (40\%) regions. Buying of votes was mentioned most in the South East (41\%) and South West (41\%).

Ten percent of respondents identified restrictions to women's electoral participation including men voting on behalf of women (7\%) and husbands not letting their wives vote $(3 \%)$. Men voting in the place of women was mentioned at least twice as often by respondents in the East $(16 \%)$ as in most other regions. Perceptions of restrictions on the electoral participation of women were particularly low in the Central/ Hazarajat and North West regions.

Intimidation of voters or party activists was mentioned by $5 \%$ of respondents overall, mostly in the North East (9\%), West (8\%), South East (6\%) and Central/ Kabul (5\%) regions. 
Table: 9.10 (Filtered) you said that you think that the election was not free and fair. What makes you think so? (Q_ 52, Base- 2457) BY REGION

\begin{tabular}{|c|c|c|c|c|c|c|c|c|c|}
\hline & $\begin{array}{l}\text { All } \\
(\%)\end{array}$ & $\begin{array}{c}\text { Central/ } \\
\text { Kabul } \\
(\%)\end{array}$ & $\begin{array}{l}\text { East } \\
(\%)\end{array}$ & $\begin{array}{c}\text { South } \\
\text { East } \\
(\%)\end{array}$ & $\begin{array}{l}\text { South } \\
\text { West } \\
(\%)\end{array}$ & $\begin{array}{l}\text { West } \\
(\%)\end{array}$ & \begin{tabular}{|c|} 
North \\
East \\
$(\%)$
\end{tabular} & $\begin{array}{l}\text { Central/ } \\
\text { Hazarajat } \\
(\%)\end{array}$ & $\begin{array}{c}\text { North } \\
\text { West } \\
(\%)\end{array}$ \\
\hline Buying of votes & 33 & 28 & 26 & 41 & 41 & 34 & 32 & 38 & 31 \\
\hline $\begin{array}{l}\text { Cheating in the vote } \\
\text { count }\end{array}$ & 40 & 44 & 41 & 40 & 33 & 39 & 39 & 43 & 41 \\
\hline $\begin{array}{l}\text { Husbands not letting } \\
\text { wives vote }\end{array}$ & 3 & 3 & 4 & 3 & 5 & 1 & 4 & 2 & 2 \\
\hline $\begin{array}{l}\text { Men voted on behalf of } \\
\text { women }\end{array}$ & 7 & 6 & 16 & 7 & 9 & 8 & 8 & 2 & 4 \\
\hline $\begin{array}{l}\text { Intimidation against } \\
\text { voters or party activists }\end{array}$ & 5 & 5 & 1 & 6 & 1 & 8 & 9 & 3 & 4 \\
\hline Don't Know & 6 & 7 & 8 & 1 & 4 & 5 & 4 & 9 & 10 \\
\hline
\end{tabular}

When the perceptions of the freeness and fairness of the 2009 presidential elections are analyzed alongside voting intentions for the 2010 parliamentary elections, a clear relationship emerges. People who said they are likely to vote in the coming parliamentary election are more likely to be those who believe that the past presidential elections were free and fair. Two-thirds $(67 \%)$ of respondents who are very likely to vote and more than half $(55 \%)$ of respondents who are somewhat likely to vote in the coming elections also think that the 2009 elections were free and fair.

On the other hand, the majority of those who say they are somewhat unlikely to vote $(55 \%)$ or are very unlikely to vote $(56 \%)$ in the 2010 parliamentary elections, think that the 2009 elections were not free and fair. This could suggest that public confidence in the quality of the electoral process has a significant positive impact on people's willingness to participate in elections. These findings seem to highlight the importance of all Afghan elections being free and fair, since irregularities with the electoral process have had a detrimental effect on people's motivation to participate.

Table 9.11: Do you think the past presidential election was free and fair? (Correlation between Q-48 and Q-51, Base all respondents 6467) BY THOSE WHO ARE VERY LIKELY, SOMEWHAT LIKELY, SOMEWHAT UNLIK ELY AND VERY UNLIKELY TO VOTE IN THE COMING PARLIAMENTARY ELECTIONS

\begin{tabular}{|l|c|c|c|c|}
\hline & $\begin{array}{c}\text { Very } \\
\text { likely } \\
\mathbf{( \% )}\end{array}$ & $\begin{array}{c}\text { Somewhat } \\
\text { likely } \\
\mathbf{( \% )}\end{array}$ & $\begin{array}{c}\text { Somewhat } \\
\text { unlikely } \\
(\mathbf{\%})\end{array}$ & $\begin{array}{c}\text { Very } \\
\text { unlikely } \\
\mathbf{( \% )}\end{array}$ \\
\hline It was free and fair & 67 & 55 & 35 & 29 \\
\hline It was not free and fair & 27 & 39 & 55 & 56 \\
\hline Refused & 1 & 0 & 1 & 1 \\
\hline Do not know & 5 & 6 & 9 & 14 \\
\hline
\end{tabular}


Another aspect that influences people's willingness to vote is their belief that elections have improved the country. All respondents were asked if they think that elections have improved the country. Around three quarters of respondents (74\%) say this is the case while $20 \%$ think it is not.

The majority of respondents in all regions say that elections have improved the country. However, a lower proportion of those living in the South West (58\%) and South East (62\%) hold this opinion compared to the other regions. Among the different ethnic communities, a higher proportion of Uzbeks (84\%) and Hazara $(79 \%)$ think elections have improved the country than do Pashtuns (70\%).

Do you think that elections have improved the country? (Q-53, Base all respondents, 6467)

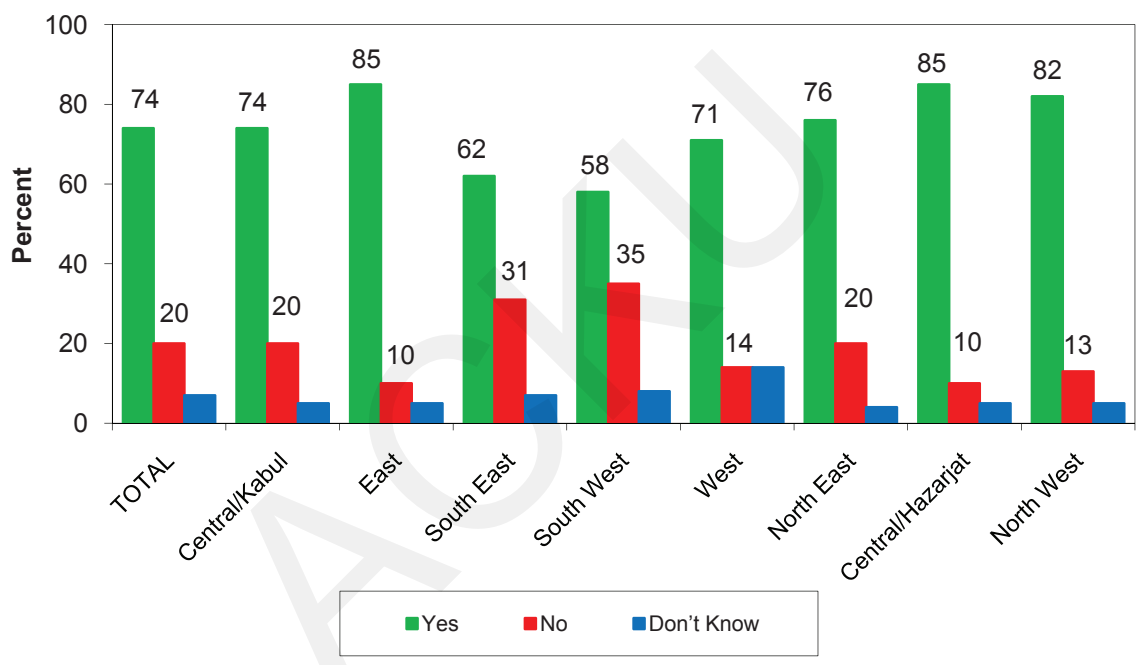

Fig. 9.24

When these responses are analyzed alongside voting intention in the coming parliamentary elections, it seems to suggest that those who are likely to vote are more likely those that believe elections have improved the country. A higher proportion of those who said they are very likely to vote $(86 \%)$ and somewhat likely to vote (78\%) think that elections have improved the country, compared to those who are somewhat unlikely to vote $(51 \%)$ and very unlikely to vote $(42 \%)$. This suggests that people are likely to use their voting rights if they believe that their votes contribute to improvements in the country. 
Table 9.12: Do you think that elections have improved the country? (Correlations between Q-48 and Q-53, Base 6467) BY THOSE WHO ARE VERY LIKELY, SOMEWHAT LIKELY, SOMEWHAT UNLIKELY AND VERY UNLIKELY TO VOTE IN THE COMING PARLIAMENTARY ELECTIONS

\begin{tabular}{|l|c|c|c|c|}
\hline & $\begin{array}{c}\text { Very } \\
\text { likely } \\
(\mathbf{\%})\end{array}$ & $\begin{array}{c}\text { Somewhat } \\
\text { likely } \\
(\mathbf{\%})\end{array}$ & $\begin{array}{c}\text { Somewhat } \\
\text { unlikely } \\
(\mathbf{\%})\end{array}$ & $\begin{array}{c}\text { Very } \\
\text { unlikely } \\
(\mathbf{\%})\end{array}$ \\
\hline Yes & 86 & 78 & 51 & 42 \\
\hline No & 9 & 17 & 40 & 46 \\
\hline Do not know & 5 & 5 & 9 & 12 \\
\hline
\end{tabular}

\subsection{The Afghan government's ability to conduct elections and the involvement of the international community}

Respondents were asked whether they were confident that the Afghan government will be able to conduct elections on its own in 2010. Two-thirds (66\%) say they are confident of this, including a quarter (24\%) who have a great deal of confidence. Thirty-one percent of respondents say they are not confident in the Afghan government's ability to hold elections, including $14 \%$ who have no confidence at all.

Levels of confidence vary significantly between regions. Confidence is highest in the East (79\%) and North West (78\%) where nearly four out of five respondents have some level of confidence that the Afghan government can run elections on its own. These are also the regions that record the highest levels of satisfaction with the performance of central government generally (see Chapter 7, 7.2 Satisfaction with the performance of the central government and 7.3 Satisfaction with central government performance in policy and service delivery).

However, the majority of respondents in the Central/Hazarajat (57\%) and South West $(58 \%)$ regions think the Afghan government can run elections on its own. In the Central/Hazarajat (40\%), Central/Kabul (36\%), North East (36\%), South East $(35 \%)$ and South West $(35 \%)$ at least a third of respondents say they have little or no confidence in the Afghan government to hold elections without external assistance. 
How confident are you that the Afghan government on its own will be able to conduct elections? (Q-54, Base 6467)

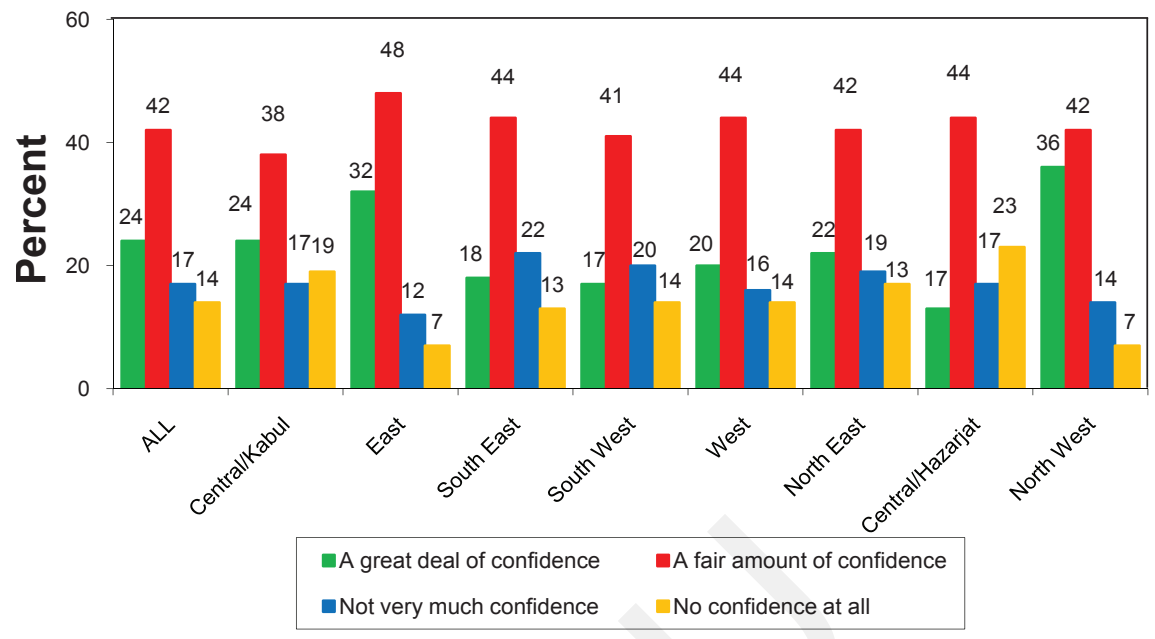

Fig. 9.25

Even though, two-thirds of respondents have some confidence that the Afghan government can run elections alone, the majority feel that the international community should still play a role. When asked the question, «Should the international community be involved with the elections?» more than half of respondents $(56 \%)$ say they should be involved while just over a third (37\%) thinks there should be no international involvement.

A much higher proportion of Hazara (67\%), Uzbeks (63\%) and other ethnic groups $(64 \%)$ think there should be some involvement of the international community than do Pashtuns (48\%). The majority of people in all regions, with the exception of the South West $(31 \%)$ and South East (45\%), think that the international community should be involved with elections. In the South West however, the majority of respondents $(58 \%)$ think the international community should not be involved in elections in Afghanistan, and this is the case for nearly half of respondents in the South East (48\%). In the West (12\%) in the South West (10\%) and in the Central Hazarajat $(9 \%)$ of respondents were not welling to answer this question. 
122 | Afghanistan in 2010

Should the international community be involved with the elections? (Q-55, Base-6467)

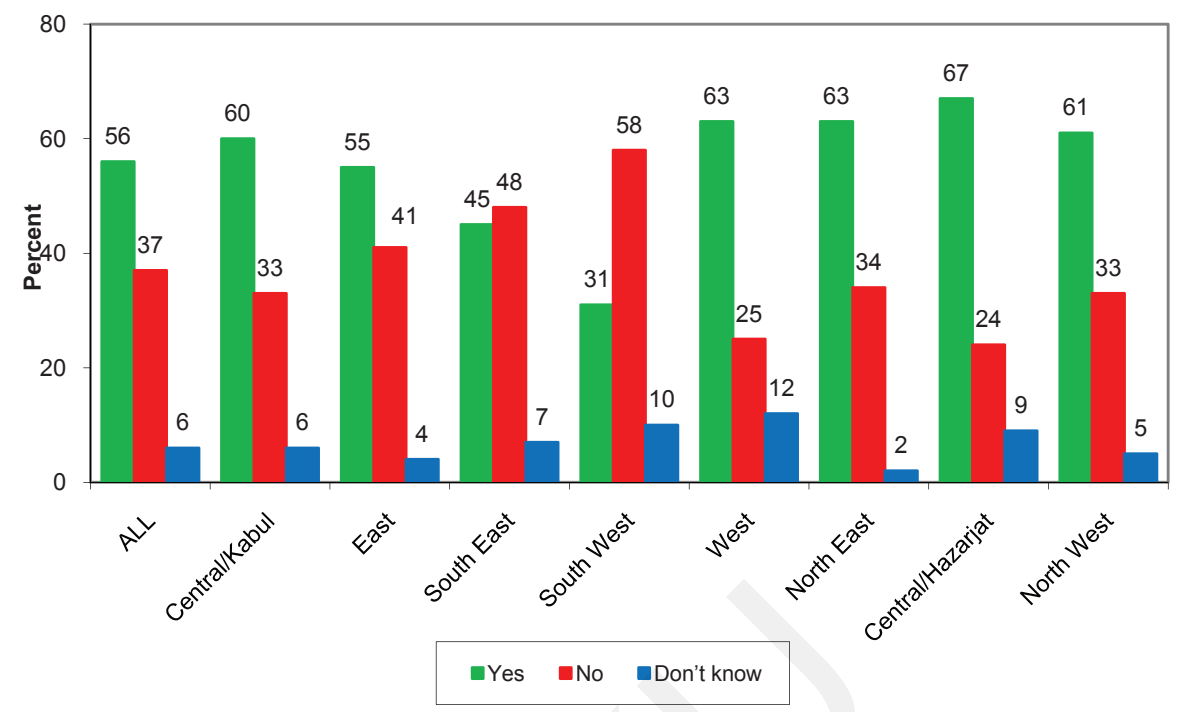

Fig. 9.26 


\section{Justice Systems}

\subsection{Dispute resolution}

The survey examined public opinion of formal and informal institutions within communities for resolving disputes. Respondents were asked if in the past year they have had a dispute they could not resolve by themselves and have therefore had to ask for help or cooperation from others to resolve. Approximately one fifth $(22 \%)$ of respondents cited that they have asked others for assistance in resolving a dispute within the past year, while $76 \%$ say they did not.

More respondents report asking others for help to resolve a problem in the South East (37\%), West (28\%), South West (27\%), and North East (26\%) than in other regions. Use of dispute resolution mechanisms was lowest in the North West $(11 \%)$, Central/Hazarajat (13\%), Central/Kabul (15\%) and East (16\%) regions. More respondents also report taking disputes to others for resolution in rural $(25 \%)$ than in urban areas $(10 \%)$.

Sometimes people and communities have problems, related to an issue that concerns everybody in their area, that they can't resolve on their own and so they have to ask for the help of a government or a non-government person, group or agency. In the past 1 year, has your community had such a problem in your area that you had to ask for help or cooperation to resolve? (Q-56, Base- 6467) BY REGION

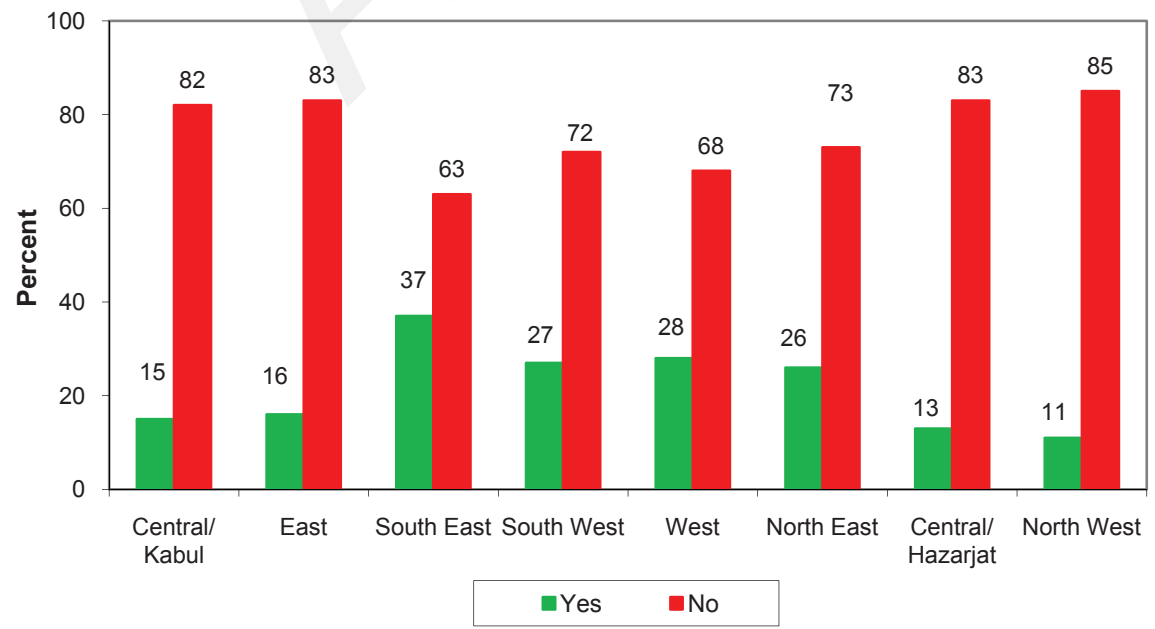

Fig. 10.1 
Respondents who took disputes for resolution ( $22 \%$ of all respondents) were asked about the nature of the problem. The most frequently mentioned problems relate to disputes over land, mentioned by $21 \%$ of respondents. Problems related to public infrastructure were also commonly mentioned, including disputes related to lack of water and electricity (11\%) and reconstruction of roads and bridges (6\%). Security problems were mentioned by $8 \%$ of respondents, and a further $7 \%$ specifically mentioned robbery/burglary. Around one in twenty respondents mentioned problems within or between social groups including tribal problems (5\%) and family problems (4\%). Economic problems were mentioned by an additional $4 \%$.

Disputes over land were most common in the South East (41\%), followed by the South West (31\%), East (27\%) and Central/Kabul (23\%) regions.

Infrastructure problems related to lack of water and electricity were most often reported in the Central/Hazarajat (55\%) and North West (37\%). Disputes related to roads were more commonly mentioned in the Central/Kabul (11\%) and North East $(10 \%)$ regions.

Security problems were identified almost twice as often in the West $(18 \%)$ as in other regions. However, disputes related to robbery/burglary were reported most in the South West (11\%), East (11\%), South East (9\%), North East (8\%), and North West (7\%).

The use of dispute resolution mechanisms to address tribal problems was highest in the North East $(10 \%)$ and West $(8 \%)$, and to resolve family problems in the North West $(8 \%)$.

Table 10.1: What kind of problem was/ is it? (Q-57, Base 1396) BY REGION

\begin{tabular}{|c|c|c|c|c|c|c|c|c|c|}
\hline & $\begin{array}{l}\text { All } \\
(\%)\end{array}$ & $\begin{array}{c}\text { Central/ } \\
\text { Kabul } \\
(\%)\end{array}$ & $\begin{array}{l}\text { East } \\
(\%)\end{array}$ & $\begin{array}{c}\text { South } \\
\text { East } \\
(\%)\end{array}$ & $\begin{array}{c}\text { South } \\
\text { West } \\
(\%)\end{array}$ & $\begin{array}{l}\text { West } \\
(\%)\end{array}$ & $\begin{array}{c}\text { North } \\
\text { East } \\
(\%)\end{array}$ & $\begin{array}{c}\text { Central/ } \\
\text { Hazarajat } \\
(\%)\end{array}$ & $\begin{array}{c}\text { North } \\
\text { West } \\
(\%)\end{array}$ \\
\hline Dispute over land & 21 & 23 & 27 & 41 & 31 & 12 & 10 & 7 & 4 \\
\hline $\begin{array}{l}\text { Lack of water and } \\
\text { electricity }\end{array}$ & 11 & 6 & 3 & 7 & 5 & 6 & 14 & 55 & 37 \\
\hline Security problems & 8 & 8 & 5 & 2 & 9 & 18 & 8 & 0 & 3 \\
\hline Robbery and burglary & 7 & 2 & 11 & 9 & 11 & 5 & 8 & 3 & 7 \\
\hline $\begin{array}{l}\text { Reconstruction of } \\
\text { roads and bridges }\end{array}$ & 6 & 11 & 3 & 7 & 2 & 4 & 10 & 3 & 6 \\
\hline Tribal problems & 5 & 3 & 4 & 2 & 2 & 8 & 10 & 0 & 2 \\
\hline Family problems & 4 & 3 & 5 & 3 & 6 & 4 & 2 & 0 & 8 \\
\hline Economic problems & 4 & 2 & 0 & 0 & 1 & 5 & 11 & 4 & 6 \\
\hline
\end{tabular}


Respondents who had taken disputes for resolution (22\% of all respondents) were then asked who they approached or asked to solve the problem. Respondents were invited to give up to three responses. The largest proportion of respondents took their disputes to a local shura or jirga for resolution (42\%). However, substantial proportions also took their disputes to local government institutions such as district authorities (31\%), local malik/khan $(27 \%)$ or the provincial governor/authorities $(18 \%)$. One in four respondents approached the Afghan National Police (ANP) $(25 \%)$, and around one in eight approached the Afghan National Army (12\%). Other local institutions that were approached to assist with dispute resolution include mullahs (18\%) and Community Development Councils (15\%). Around one in ten respondents approached a government agency $(11 \%)$ or a member of parliament $(10 \%)$ to assist in resolving a dispute. Only small numbers of respondents approached external agencies such as NGOs (4\%), Provincial Reconstruction Teams (PRT) (3\%), foreign forces (2\%), or a specialized national institution like the Human Rights Commission $(2 \%)$. One percent of respondents report taking a dispute to the Taliban for resolution.

There are some differences in the dispute resolution mechanisms used by men and women. Slightly more men (42\%) than women (38\%) approached elders of the local shura/jirga, whereas a higher proportion of women (15\%) than men (9\%) said they approached Community Development Councils.

Table 10.2: Who did you approach/ask to solve the problem? (Q-58a_c, Base 1396)

\begin{tabular}{|l|l|}
\hline Elders of the local shura/Jirga & 42 \\
\hline District authorities & 31 \\
\hline Malik / Khan & 27 \\
\hline Afghan National Police & 25 \\
\hline Provincial governor/ authorities & 18 \\
\hline Mullah & 18 \\
\hline Community Development Council & 15 \\
\hline Afghan National Army & 12 \\
\hline Government agency/office & 11 \\
\hline A Member of Parliament & 10 \\
\hline NGO & 4 \\
\hline Provincial Reconstruction team (PRT) & 3 \\
\hline Foreign Forces & 2 \\
\hline Human Rights Commission & 2 \\
\hline Taliban & 1 \\
\hline
\end{tabular}

As expected, the survey reveals significant differences in the kinds of problems taken to the various institutions. Disputes involving security problems were most fre- 
quently reported to the Afghan National Police (17\%), provincial authorities (15\%) and Afghan National Army (12\%) as the agencies responsible for maintaining security. Disputes involving robbery and burglary were also most often reported to the police $(10 \%)$ although these were reported to the full range of other available local institutions as well.

Infrastructure and development-related problems were mostly reported to the Community Development Council (CDC) which has a mandate to identify local development needs at the village level. More than a quarter of disputes related to lack of water and electricity $(26 \%)$ were referred to CDCs, and the same is true for $15 \%$ of disputes related to roads. After CDCs, respondents most frequently took disputes about infrastructure to local government at the district and provincial levels.

On the other hand, land disputes were referred to a wide variety of social and governmental institutions. Around a third of respondents (34\%) say they took their land dispute to a mullah, $28 \%$ went to a local shura/jirga, and $27 \%$ to a malik $/ \mathrm{khan}$. At least one in eight respondents took their land dispute to a local government body for resolution, including the district authority (20\%), the provincial government $(13 \%)$ or the Community Development Council (13\%). Fifteen percent of respondents took their land dispute to the police for resolution.

Table 10.3: What kind of problem was that? (Q-57 \& Q58a-c,) COMPARISON BY PLACE APPROACHED TO SOLVE THE PROBLEM

\begin{tabular}{|c|c|c|c|c|c|c|c|}
\hline & $\begin{array}{c}\text { Shura/ } \\
\text { Jirga } \\
(\%)\end{array}$ & \begin{tabular}{c|} 
ANP \\
$(\%)$
\end{tabular} & $\begin{array}{c}\text { Malik/ } \\
\text { Khan } \\
(\%)\end{array}$ & $\begin{array}{l}\text { Provincial } \\
\text { authority } \\
(\%)\end{array}$ & $\begin{array}{l}\text { CDC } \\
(\%)\end{array}$ & $\begin{array}{c}\text { District } \\
\text { authority } \\
(\%)^{.}\end{array}$ & $\begin{array}{c}\text { Mullah } \\
(\%)\end{array}$ \\
\hline Dispute over land & 28 & 15 & 27 & 13 & 13 & 20 & 34 \\
\hline Lack of water and electricity & 9 & 4 & 13 & 18 & 26 & 15 & 4 \\
\hline $\begin{array}{l}\text { Reconstruction of roads } \\
\text { and bridges }\end{array}$ & 7 & 3 & 4 & 9 & 15 & 9 & 3 \\
\hline Robbery and burglary & 6 & 10 & 7 & 3 & 5 & 8 & 8 \\
\hline Security problems & 6 & 17 & 7 & 15 & 7 & 9 & 5 \\
\hline
\end{tabular}

Respondents who contacted shura/jirga to resolve their problems were asked what made them decide to take the dispute to this body instead of the State Court. One third of respondents (35\%) say this was because local shura/jirga are honest. Another $15 \%$ say it is because of corruption in government courts and $10 \%$ say they preferred this mechanism because shura /jirga resolve disputes efficiently.

The honesty of local shura/Jjrga is most often mentioned in the Central/Hazarajat 
(56\%) and South East (52\%), followed by the Central/Kabul (35\%) and North West $(34 \%)$. The problem of corruption in state courts is specifically mentioned by a much higher proportion of respondents in the East (32\%), South East (22\%) and North East (18\%) than in other regions.

Table 10.4: What made you decide to take your dispute to the Shura/Jirga vs State Court? (Q-60, Base 582)BY REGION

\begin{tabular}{|c|c|c|c|c|c|c|c|c|c|}
\hline & $\begin{array}{l}\text { All } \\
(\%)\end{array}$ & $\begin{array}{c}\text { Central } \\
\text { Kabul } \\
(\%)\end{array}$ & $\begin{array}{l}\text { East } \\
(\%)\end{array}$ & $\begin{array}{c}\text { South } \\
\text { East } \\
(\%)\end{array}$ & \begin{tabular}{|c|} 
South \\
West \\
$(\%)$
\end{tabular} & $\begin{array}{l}\text { West } \\
(\%)\end{array}$ & $\begin{array}{c}\text { North } \\
\text { East } \\
(\%)\end{array}$ & $\begin{array}{c}\text { Central } \\
\text { Hazarajat } \\
(\%)\end{array}$ & $\begin{array}{c}\text { North } \\
\text { West } \\
(\%)\end{array}$ \\
\hline $\begin{array}{l}\text { Because local shura } \\
\text { are honest }\end{array}$ & 35 & 35 & 30 & 52 & 22 & 25 & 28 & 56 & 34 \\
\hline $\begin{array}{l}\text { Corruption in govern- } \\
\text { ment courts }\end{array}$ & 15 & 9 & 32 & 22 & 3 & 9 & 18 & 0 & 9 \\
\hline $\begin{array}{l}\text { Resolve disputes ef- } \\
\text { ficiently }\end{array}$ & 10 & 6 & 2 & 2 & 3 & 12 & 24 & 11 & 11 \\
\hline $\begin{array}{l}\text { Are not related to the } \\
\text { courts }\end{array}$ & 5 & 4 & 2 & 12 & 2 & 0 & 4 & 0 & 2 \\
\hline Don't know & 27 & 34 & 29 & 12 & 54 & 35 & 19 & 33 & 35 \\
\hline
\end{tabular}

All respondents who have taken problems to either formal or informal institutions for resolution were asked if their problems have been resolved. More than half of respondents $(56 \%)$ say their problems have been resolved while just over a third $(37 \%)$ state they are pending resolution. However, there are differences between regions. Around two-thirds of respondents report that their problem has been resolved in the South West (67\%) and South East (64\%), and this is also true for the majority of respondents in the East (57\%), West (56\%), Central/Kabul (54\%) and North East (51\%) regions. However the majority of disputes are still pending resolution in the North West (51\%) and in the Central/Hazarajat (79\%) regions ${ }^{7}$. In the Central Hazarajat (11\%) in South West $(10 \%)$ and in the East $(9 \%)$ of respondents were not welling to respond to this question.

The low level of resolution of disputes in the Central/Hazarajat is likely to be due to the fact that a much smaller number of cases were brought for resolution in this region (29 cases compared to between 100 and 255 in other regions), which means that the lack of resolution of a small number of cases has a disproportionate effect on overall resolution rates in percentage terms. 
Has this problem been resolved or it's still pending resolution? (Filtered, Q-61, Base 1396) BY REGION

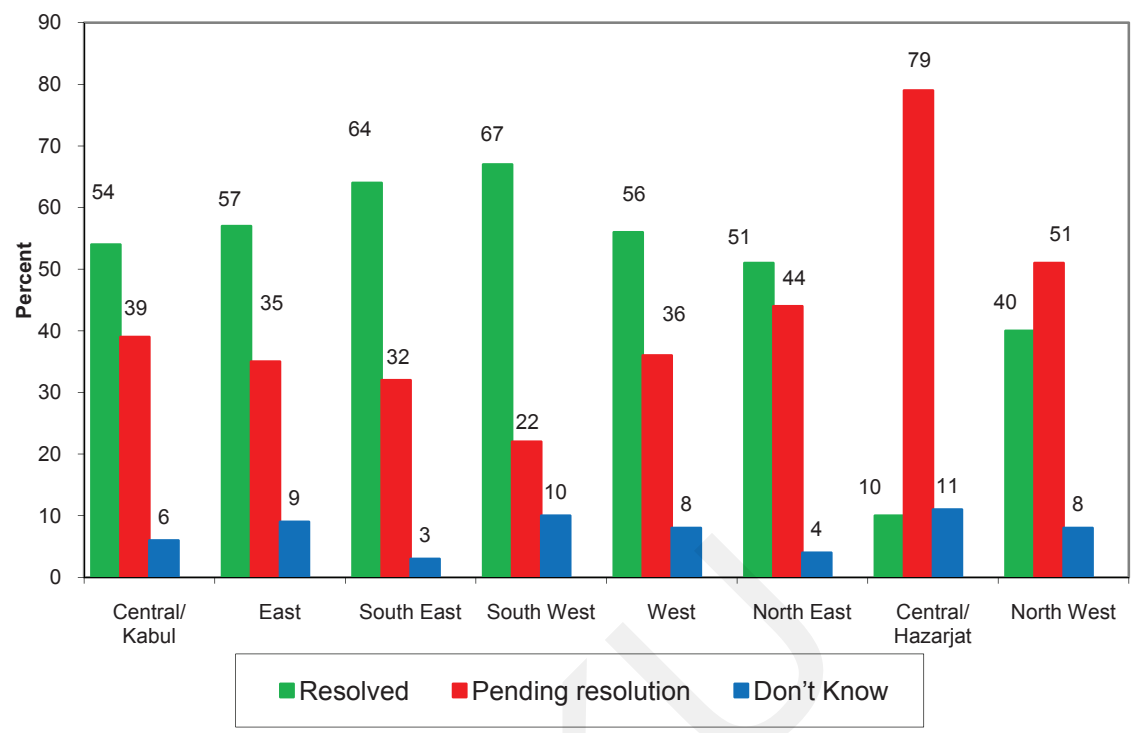

Fig. 10.2

Looking at the resolution rates for disputes taken to different institutions it becomes clear that dispute resolution mechanisms that are strongly anchored in local communities are amongst the most effective in resolving disputes. The majority of respondents who submitted disputes to mullahs $(72 \%)$ and local shura and jirga (63\%) say their dispute has been resolved.

Institutions with specialized mandates also appear to be generally effective at resolving disputes in their area of competence, including the Afghan National Army (67\%), Afghan National Police (63\%) and the Human Rights Commission (60\%), even though this last institution dealt with a much smaller number of disputes (30 in total).

Local government institutions that have wide mandates have somewhat lower resolution rates, although the majority of respondents who took disputes to malik/khan $(58 \%)$, district authorities $(56 \%)$, and provincial authorities $(53 \%)$ still report that their dispute was resolved.

Resolution rates are lowest for agencies whose work is also dependent on external partners such as foreign donors. Only around a quarter $(24 \%)$ of those who took a dispute to an NGO report that the dispute has been resolved. The same is true for under half of those who took disputes to Provincial Reconstruction Teams (42\%), or foreign forces (43\%). A similar proportion (42\%) reported that members of parliament helped to resolve their disputes. 
Table 10.5: (Filtered) Has this problem been resolved or it's still pending resolution? (Correlation of Q-61 with Q-58a-c) BY PLACE APPROACHED TO SOLVE THE PROBLEM

\begin{tabular}{|l|c|c|c|}
\hline & $\begin{array}{c}\text { Disputes } \\
\text { submitted } \\
\mathbf{( \% )}\end{array}$ & $\begin{array}{c}\text { Resolved } \\
\mathbf{( \% )}\end{array}$ & $\begin{array}{c}\text { Pending } \\
\text { resolution } \\
\mathbf{( \% )}\end{array}$ \\
\hline Local Shura/ Jirga & 43 & 63 & 36 \\
\hline District authorities & 31 & 56 & 41 \\
\hline Malik/Khan & 27 & 58 & 39 \\
\hline Afghan National Police & 25 & 63 & 32 \\
\hline Mullah & 18 & 72 & 27 \\
\hline Community Development Council & 15 & 44 & 53 \\
\hline Provincial governor/ authorities & 14 & 53 & 46 \\
\hline Afghan National Army & 12 & 67 & 30 \\
\hline Govt. agency/ office & 11 & 49 & 48 \\
\hline Member of Parliament & 10 & 42 & 51 \\
\hline NGO & 4 & 24 & 71 \\
\hline Provincial Reconstruction Team (PRT) & 3 & 42 & 58 \\
\hline Human Rights Comm. & 2 & 60 & 32 \\
\hline Foreign forces & 2 & 43 & 39 \\
\hline
\end{tabular}

All respondents, whether or not they had taken a dispute for resolution in the last year, were asked how satisfied they are with the available dispute resolution mechanisms or services in their area. The majority of respondents (70\%) say they are satisfied, including $21 \%$ who say they are very satisfied, while around a quarter $(26 \%)$ say they are not.

How satisfied you are with the available disputes resolution mechanisms/services in your area? (Q-63, Base 6467)

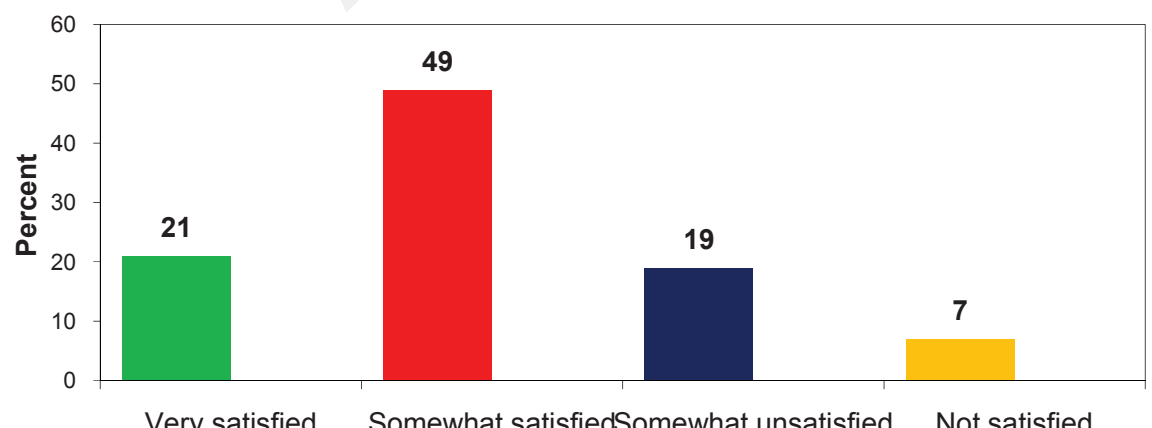

Fig. 10.3 
Levels of satisfaction with available dispute resolution mechanisms are highest in the North West (81\%), followed by the North East (74\%), West (73\%), Central Kabul $(70 \%)$, East (68\%), Central Hazarajat (67\%) and the South East (66\%), and lowest in the South West $(52 \%)$.

How satisfied you are with the available disputes resolution mechanisms/services in your area? (Q-63, Based 6467) BY REGION

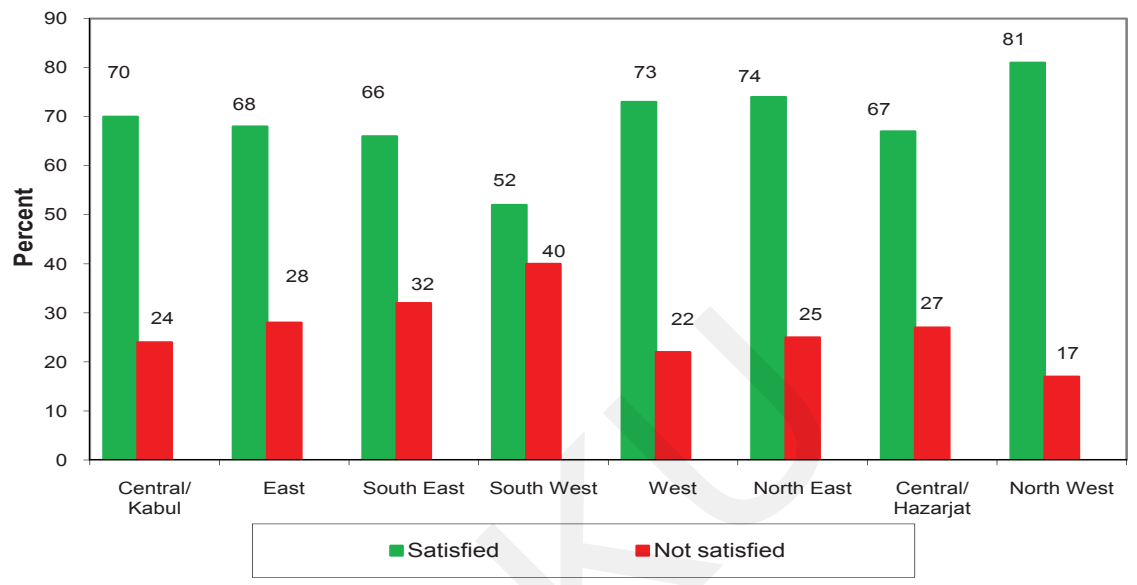

Fig. 10.4

\subsection{Perceptions of state courts}

To gauge public perceptions of state courts, a series of statements related to the quality and performance of this institution was read out and respondents were asked to say whether they agree or disagree. Levels of agreement with each of the statements are shown in the table below.

Table 10.6: Perceptions of the qualities and performance of state courts (Q-64a-f, Base 6467)

\begin{tabular}{l|c|c|c|c|} 
& $\begin{array}{c}\text { Strongly } \\
\mathbf{a g r e e} \\
\mathbf{( \% )}\end{array}$ & $\begin{array}{c}\text { Agree } \\
\text { somewhat } \\
\mathbf{( \% )}\end{array}$ & $\begin{array}{c}\text { Disagree } \\
\text { somewhat } \\
\mathbf{( \% )}\end{array}$ & $\begin{array}{c}\text { Strongly } \\
\text { disagree } \\
\mathbf{( \% )}\end{array}$ \\
\hline a) State courts are accessible to me & 28 & 45 & 18 & 8 \\
\hline b) State courts are fair and trusted & 13 & 40 & 31 & 13 \\
\hline $\begin{array}{l}\text { c) State courts are not corrupt compared to } \\
\text { others }\end{array}$ & 12 & 37 & 33 & 15 \\
\hline $\begin{array}{l}\text { d) State courts follow the local norms and } \\
\text { values of our people }\end{array}$ & 13 & 38 & 32 & 14 \\
\hline e) State courts are effective at delivering justice & 16 & 38 & 29 & 15 \\
\hline f) State courts resolve cases timely and promptly & 11 & 31 & 32 & 23 \\
\hline
\end{tabular}


Around three quarters of respondents $(73 \%)$ agree with the statement that "state courts are accessible to me." The majority also agree that state courts are effective at delivering justice (54\%), are fair and trusted (53\%), and follow local norms and values (51\%). However, less than half of respondents agree that state courts are not corrupt compared to other institutions $(49 \%)$ or that they resolve cases promptly (42\%). This reflects the finding that the majority of respondents that had contact with the state courts in the last year encountered some level of corruption (see Chapter 8, 8.2 Payment of bribes). It also helps to explain the low levels of public confidence in the government justice system (48\%) (see Chapter 7, 7.1 Confidence in public institutions).

Satisfaction with the performance of state courts is highest across almost all domains in the East and North West, which are also the regions that report the highest levels of satisfaction with government performance and public service delivery in general (see Chapter 7 7.2 Satisfaction with the performance of the central government and 7.3 Satisfaction with central government performance in policy and service delivery). Satisfaction is lowest across almost all domains in the South West and South East

Table 10.7 Percentage of respondents who agree (combination of strongly agree and somewhat agree) with various statement related to state courts (Q-64a-f, Base 6467)

\begin{tabular}{l|c|c|c|c|c|c|c|c|} 
& $\begin{array}{c}\text { Central } \\
\text { Kabul }\end{array}$ & East & $\begin{array}{c}\text { South } \\
\text { East }\end{array}$ & $\begin{array}{c}\text { South } \\
\text { West }\end{array}$ & West & $\begin{array}{c}\text { North } \\
\text { East }\end{array}$ & $\begin{array}{c}\text { Central } \\
\text { Hazarajat }\end{array}$ & $\begin{array}{c}\text { North } \\
\text { West }\end{array}$ \\
\hline & $\mathbf{( \% )}$ & $\mathbf{( \% )}$ & $\mathbf{( \% )}$ & $\mathbf{( \% )}$ & $\mathbf{( \% )}$ & $\mathbf{( \% )}$ & $\mathbf{( \% )}$ & $\mathbf{( \% )}$ \\
\hline $\begin{array}{l}\text { a) Are accessible } \\
\text { to me }\end{array}$ & 77 & 83 & 64 & 57 & 79 & 68 & 73 & 78 \\
\hline $\begin{array}{l}\text { b) Are fair and } \\
\text { trusted }\end{array}$ & 55 & 66 & 39 & 37 & 57 & 53 & 61 & 63 \\
\hline $\begin{array}{l}\text { c) Are not corrupt } \\
\text { compared to other } \\
\text { dispute resolution } \\
\text { options }\end{array}$ & 49 & 57 & 43 & 31 & 49 & 52 & 51 & 60 \\
$\begin{array}{l}\text { d) Follow the local } \\
\text { norms and values of } \\
\text { our people }\end{array}$ & 52 & 59 & 42 & 41 & 54 & 51 & 56 & 59 \\
$\begin{array}{l}\text { e) Are effective at } \\
\text { delivering justice }\end{array}$ & 53 & 59 & 48 & 38 & 54 & 53 & 65 & 65 \\
\hline $\begin{array}{l}\text { f) Resolve cases } \\
\text { timely and promptly }\end{array}$ & 41 & 55 & 33 & 34 & 37 & 39 & 35 & 57 \\
\hline
\end{tabular}

Satisfaction with the performance of state courts across all the listed dimensions shows a small improvement in 2010 compared to the past two years. However, satisfaction remains below the levels recorded in 2007. The steepest decline concerns the 
ability of state courts to resolve cases promptly. While $51 \%$ of respondents agreed with this statement in 2007, only $42 \%$ agree in 2010, but this is still an improvement from $2008(38 \%)$ and $2009(40 \%)$.

Table 10.8: Proportion of those who agree with the following statements about state courts (Q64a-f) COMPARISON BETWEEN 2007, 2008, 2009 AND 2010

\begin{tabular}{l|c|c|c|c|} 
& $\begin{array}{c}\mathbf{2 0 0 7} \\
\mathbf{( \% )}\end{array}$ & $\begin{array}{c}\mathbf{2 0 0 8} \\
\mathbf{( \% )}\end{array}$ & $\begin{array}{c}\mathbf{2 0 0 9} \\
\mathbf{( \% )}\end{array}$ & $\begin{array}{c}\mathbf{2 0 1 0} \\
\mathbf{( \% )}\end{array}$ \\
\hline a) State courts are accessible to me & 78 & 68 & 68 & 73 \\
\hline b) State courts are fair and trusted & 58 & 50 & 50 & 53 \\
\hline c) State courts are not corrupt compared to others & 56 & 47 & 47 & 49 \\
\hline $\begin{array}{l}\text { d) State courts follow the local norms and values of } \\
\text { our people }\end{array}$ & 57 & 50 & 49 & 51 \\
\hline e) State courts are effective at delivering justice & 58 & 52 & 51 & 54 \\
\hline f) State courts resolve cases timely and promptly & 51 & 38 & 40 & 42 \\
\hline
\end{tabular}

\subsection{Perceptions of local shura and jirga}

To assess the public's perception of informal justice mechanisms, respondents were asked about the quality and performance of local jirga and shura in the same manner as they had been asked about state courts. Levels of agreement with each of the statements are summarized in the table below.

Table 10.9: Perceptions of the qualities and performance of local shura/jirga (Q-65a-e, Base 6467)

\begin{tabular}{l|c|c|c|c|} 
& $\begin{array}{c}\text { Strongly } \\
\text { agree } \\
\mathbf{( \% )}\end{array}$ & $\begin{array}{c}\text { Agree } \\
\text { somewhat } \\
\mathbf{( \% )}\end{array}$ & $\begin{array}{c}\text { Disagree } \\
\text { somewhat } \\
\mathbf{( \% )}\end{array}$ & $\begin{array}{c}\text { Strongly } \\
\text { disagree } \\
\mathbf{( \% )}\end{array}$ \\
\hline a) Local jirga/ shura are accessible to me & 43 & 43 & 9 & 4 \\
\hline b) Local jirga/ shura are fair and trusted & 27 & 46 & 21 & 5 \\
\hline $\begin{array}{l}\text { c) Local jirga/ shura follow the local norms } \\
\text { and values of our people. }\end{array}$ & 27 & 43 & 23 & 6 \\
\hline $\begin{array}{l}\text { d) Local jirga/ shura are effective at delive- } \\
\text { ring justice }\end{array}$ & 26 & 43 & 22 & 7 \\
\hline $\begin{array}{l}\text { e) Local jirga/ shura resolve cases timely and } \\
\text { promptly }\end{array}$ & 28 & 38 & 23 & 8 \\
\hline
\end{tabular}

More than four-fifths $(86 \%)$ of respondents agree that local jirga/shura are accessible. Around three quarters agree that local jirga/shura are fair and trusted $(73 \%)$ and more than two-thirds agree that they follow local norms and values $(70 \%)$, are effective at delivering justice (69\%) and resolve cases promptly (66\%). 
Respondents in all regions are most positive about the accessibility of shura and jirga. Positive assessment of local shura/jirga is highest across all domains in the East, North East and North West. The East and North West are also the regions that record the highest levels of satisfaction with state courts (see previous section), suggesting that respondents see these mechanisms as complementary to each other rather than operating in opposition to each other. Satisfaction is lowest in the South West, which also records the lowest levels of satisfaction with state courts, and in the Central/Hazarajat region.

Table 10.10 Percentage of respondents who agree (combination of strongly agree and somewhat agree) with various statement related to jirga/ shura (Q-65a-e, Base 6467)

\begin{tabular}{|l|c|c|c|c|c|c|c|c|} 
& $\begin{array}{c}\text { Central } \\
\text { Kabul } \\
\mathbf{( \% )}\end{array}$ & $\begin{array}{c}\text { East } \\
\mathbf{( \% )}\end{array}$ & $\begin{array}{c}\text { South } \\
\text { East } \\
\mathbf{( \% )}\end{array}$ & $\begin{array}{c}\text { South } \\
\text { West } \\
\mathbf{( \% )}\end{array}$ & $\begin{array}{c}\text { West } \\
\mathbf{( \% )}\end{array}$ & $\begin{array}{c}\text { North } \\
\text { East } \\
\mathbf{( \% )}\end{array}$ & $\begin{array}{c}\text { Central } \\
\text { Hazarajat } \\
\mathbf{( \% )}\end{array}$ & $\begin{array}{c}\text { North } \\
\text { West } \\
\mathbf{( \% )}\end{array}$ \\
\hline \begin{tabular}{l} 
a) Are accessible to me \\
\hline b) Are fair and trusted
\end{tabular} & 73 & 89 & 90 & 73 & 88 & 90 & 81 & 91 \\
\hline $\begin{array}{l}\text { c) Follow the local } \\
\text { norms and values of our } \\
\text { people }\end{array}$ & 71 & 76 & 74 & 54 & 64 & 74 & 65 & 75 \\
$\begin{array}{l}\text { d) Are effective at deliv- } \\
\text { ering justice }\end{array}$ & 71 & 76 & 69 & 55 & 63 & 72 & 60 & 74 \\
\hline $\begin{array}{l}\text { e) Resolve cases timely } \\
\text { and promptly }\end{array}$ & 69 & 80 & 71 & 54 & 59 & 67 & 47 & 73 \\
\hline
\end{tabular}

As with state courts, satisfaction with the performance of local jirga/shura across all dimensions also shows a small improvement in 2010 compared to the past three years, particularly in terms of their accessibility. However, satisfaction in the other dimensions remains below the levels recorded in 2007.

Table 10.11: Proportion of those who agree with the following statements about jirga/shura (Q65a-e) COMPARISON BETWEEN 2007, 2008, 2009 AND 2010

\begin{tabular}{|c|c|c|c|c|}
\hline & $\begin{array}{c}2007 \\
(\%)\end{array}$ & $\begin{array}{c}2008 \\
(\%)\end{array}$ & $\begin{array}{c}2009 \\
(\%)\end{array}$ & $\begin{array}{r}2010 \\
(\%)\end{array}$ \\
\hline a) Local jirga/shura are accessible to me & 83 & 76 & 79 & 86 \\
\hline b) Local jirga/shura are fair and trusted & 78 & 70 & 72 & 73 \\
\hline $\begin{array}{l}\text { c) Local jirga/shura follow the local norms and values } \\
\text { of our people. }\end{array}$ & 76 & 69 & 70 & 70 \\
\hline d) Local jirga/shura are effective at delivering justice & 76 & 69 & 69 & 69 \\
\hline e) Local jirga/shura resolve cases timely and promptly & 72 & 59 & 64 & 66 \\
\hline
\end{tabular}


The table below compares respondents' assessments of state courts and local shura/ jirga. On all five counts the traditional justice system is seen to perform better than the modern state justice system.

Table 10.12 Percentage of respondents who agree (combination of strongly agree and somewhat agree) with various statement related to state courts and jirga/ shura (Q-64 and Q-65, Base 6467)

\begin{tabular}{|l|c|c|}
\hline \multirow{2}{*}{} & \multicolumn{2}{|c|}{ Agree } \\
\cline { 2 - 3 } & State Court & $\begin{array}{c}\text { Shura/Jirga } \\
\mathbf{( \% )}\end{array}$ \\
\hline Are accessible to me & $\mathbf{( \% )}$ & 86 \\
\hline Are fair and trusted & 73 & 73 \\
\hline Follow the local norms and values of our people & 53 & 70 \\
\hline Are effective at delivering justice & 51 & 69 \\
\hline Resolve cases timely and promptly & 54 & 66 \\
\hline
\end{tabular}

Overall, these results demonstrate that many Afghans continue to view traditional dispute resolution mechanisms such as jirga and shura more positively than they do the modern formal justice system such as state courts. These findings corroborate the higher levels of public confidence recorded for shura and jirga ( $66 \%$ confidence) than for the state justice system (48\% confidence) (see Chapter 7, 7.1: Confidence with various institutions, Table 7.1). 


\section{Women in Society}

\subsection{Biggest problems faced by women}

The survey endeavored to understand the particular problems faced by women in Afghan society. All respondents were asked to identify the biggest problems Afghan women face. Around one-third (31\%) of respondents identify illiteracy and lack of education as the biggest problem faced by women in their area. Another $(15 \%)$ mention the lack of job opportunities for women, 7\% say lack of women's rights and the same proportion mention domestic violence. Five percent identify pregnancy-related health care and forced marriages/dowry as the biggest problems faced by women in their local area. In the meantime $(13 \%)$ of respondents were not welling to answer this question.

What are the biggest problems facing women in this area today? (Q-66, Base 6467)

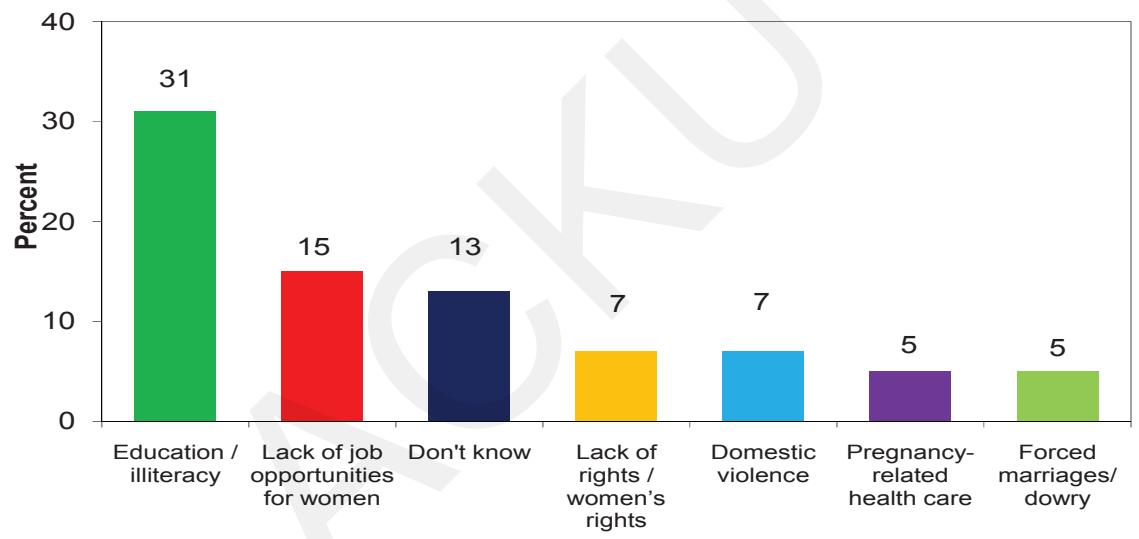

Fig. 11.1

Men and women identify similar issues when asked about the biggest problems that women face. Both identify education/illiteracy followed by lack of job opportunities as the biggest problems for women. However, a higher proportion of women $(19 \%)$ than men $(12 \%)$ cite the lack of job opportunities for women, whereas twice as many men $(6 \%)$ as women $(3 \%)$ mention pregnancy-related health care.

The response to this question also varies by income levels. A higher proportion of those with lower incomes identify the lack of job opportunities than those with higher incomes. For instance, among those earning between Afs.5,000-10,000 a month, $11 \%$ identify access to paid work as the biggest problem for women. This rises to $15 \%$ among those earning between Afs.3000-5000, 17\% amongst those earning between Afs.2000-3000 and 24\% amongst the lowest income group who earn less than Afs. 2000 per month. 
Across the country, illiteracy and the lack of education is identified as the biggest problem facing women in all regions, with the highest proportions recorded in the Central/Hazarajat (39\%), South East (37\%) and Central/Kabul (36\%) regions. Issues of illiteracy and education are least often identified in the South West $(19 \%)$ and East $(24 \%)$.

The lack of job opportunities for women is particularly identified in the North West (31\%) and North East (23\%), followed by the Central/Hazarajat (18\%), Central/ Kabul (13\%) and West (13\%) regions. The Central/Kabul, Central/Hazarajat and North West are also the regions that record the highest level of concern that unemployment is the biggest problem facing the country as a whole (see Chapter 2, 2.4 Afghanistan's biggest problems: National level), and the North East (27\%) and Central/Kabul (27\%) regions are amongst those that most often identify unemployment as a major local problem (see Chapter 2, 2.5 Afghanistan's biggest problems: Local level). This may suggest that concern about job opportunities for women is often part of an overall concern about employment, rather than a specific issue for women. However, the Central/Kabul, Central/Hazarajat, North West and North East are also the regions where the largest number of respondents say that women should be allowed to work outside the home (see below, 11.3 Attitudes towards gender equality: women and employment), suggesting that there is greater demand and opportunity for women to take jobs in these regions.

The lack of women's rights is most frequently cited as the biggest problem facing women in the South East (13\%) and North East (13\%)

One in five respondents in the West (21\%), and at least one in ten in the Central/ Kabul (16\%), North West (15\%), South West (13\%) and East (11\%) say they don't know what are the biggest problems facing women.

Table 11.1: What are the biggest problems facing women in this area today? (Q-66, Base 6467)

\begin{tabular}{|l|c|c|c|c|c|c|c|c|}
\hline & $\begin{array}{c}\text { Central/ } \\
\text { Kabul } \\
(\mathbf{\%})\end{array}$ & $\begin{array}{c}\text { East } \\
\mathbf{( \% )}\end{array}$ & $\begin{array}{c}\text { South } \\
\text { East } \\
\mathbf{( \% )}\end{array}$ & $\begin{array}{c}\text { South } \\
\text { West } \\
(\mathbf{\%})\end{array}$ & $\begin{array}{c}\text { West } \\
\mathbf{( \% )}\end{array}$ & $\begin{array}{c}\text { North } \\
\text { East } \\
\mathbf{( \% )}\end{array}$ & $\begin{array}{c}\text { Central/ } \\
\text { Hazarajat } \\
\mathbf{( \% )}\end{array}$ & $\begin{array}{c}\text { North } \\
\text { West } \\
\mathbf{( \% )}\end{array}$ \\
\hline $\begin{array}{l}\text { Education /illiteracy } \\
\text { Lack of job opportunities } \\
\text { for women }\end{array}$ & 13 & 37 & 24 & 39 & 33 & 19 & 31 & 31 \\
\hline $\begin{array}{l}\text { Lack of rights / } \\
\text { women's rights }\end{array}$ & 3 & 8 & 9 & 18 & 23 & 5 & 31 & 13 \\
\hline Don't know & 16 & 4 & 11 & 5 & 6 & 13 & 15 & 21 \\
\hline
\end{tabular}

Since 2006, illiteracy and lack of education have consistently been identified as the biggest problems for women in Afghanistan. Over the same period, there has also 
been a consistent rise in the proportion of respondents who identify the lack of employment opportunities for women, from $9 \%$ in 2007 , to $11 \%$ in $2008,14 \%$ in 2009 and $15 \%$ in 2010. On the other hand, the proportion of respondents who identify the lack of women's rights as a major problem for women has been falling consistently, from 14\% in 2006 and 13\% in 2007 and 2008, to $11 \%$ in 2009 and 7\% in 2010. The identification of domestic violence and pregnancy-related health care as major problems for Afghan women has remained basically stable. Conversely, the proportion of respondents who identify forced marriages and dowry as a major problem has fluctuated since 2006, but the proportion remained stable from 2009 (4\%) to $2010(5 \%)$.

What are the biggest problems facing women in this area today? (Q-66) COMPARISON BETWEEN 2006, 2007, 2008, 2009 and 2010

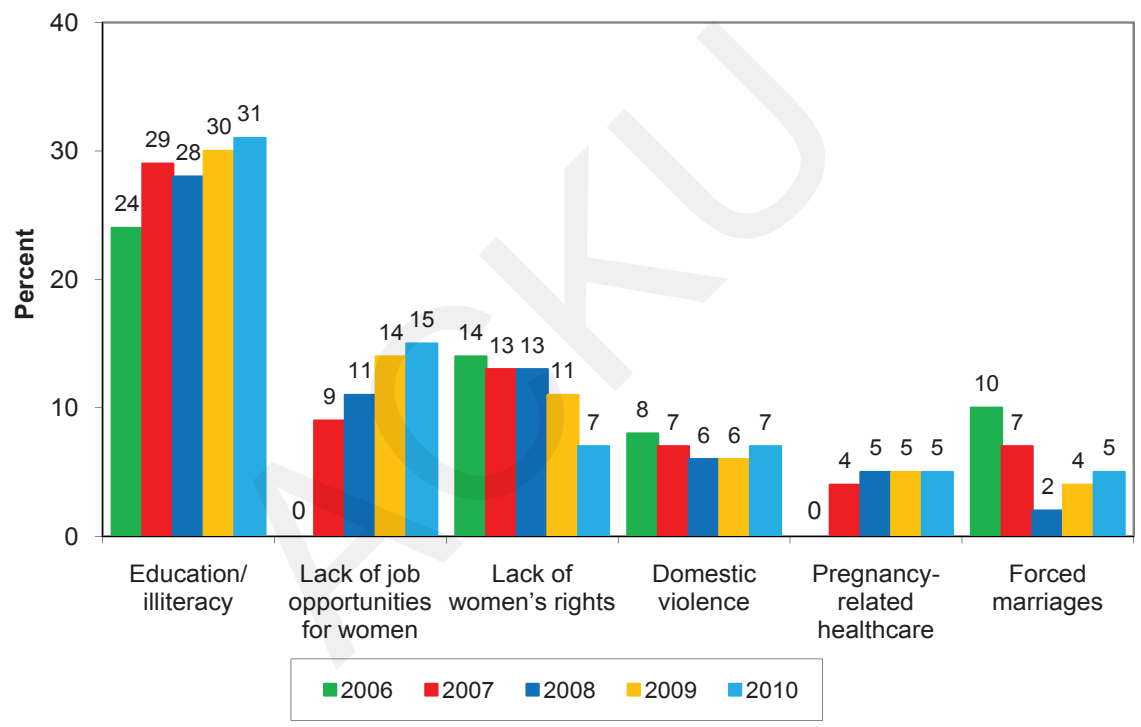

Fig. 11.2

\subsection{Attitudes toward gender equality: women and education}

The survey also sought to measure public opinion on the issue of gender equality. The first issue relates to gender equality in education. Respondents were asked whether they agree with the statement: "Women should have equal opportunities like men in education." Over four-fifths $(87 \%)$ of respondents say they agree with this statement, including 50\% who strongly agree. Only around one in ten $(11 \%)$ disagree. These responses are broadly consistent with the high level of public agreement for equal rights under the law, regardless of gender, ethnicity or religion $(81 \%)$ (see Chapter 9, 9.5: Democratic spirit of government). 
A higher proportion of women (93\%) than men (82\%) support equal opportunities for women in education. Urban residents are also more likely to support equal educational opportunities for women $(92 \%)$ compared to their rural counterparts $(86 \%)$. However there is very little difference in views between respondents in different age groups or with different levels of education and income.

Some people say that women should have equal opportunities like men in education. Do you agree or disagree with this opinion? (Q-67, Base 6467) BY GENDER AND SETTLMENT

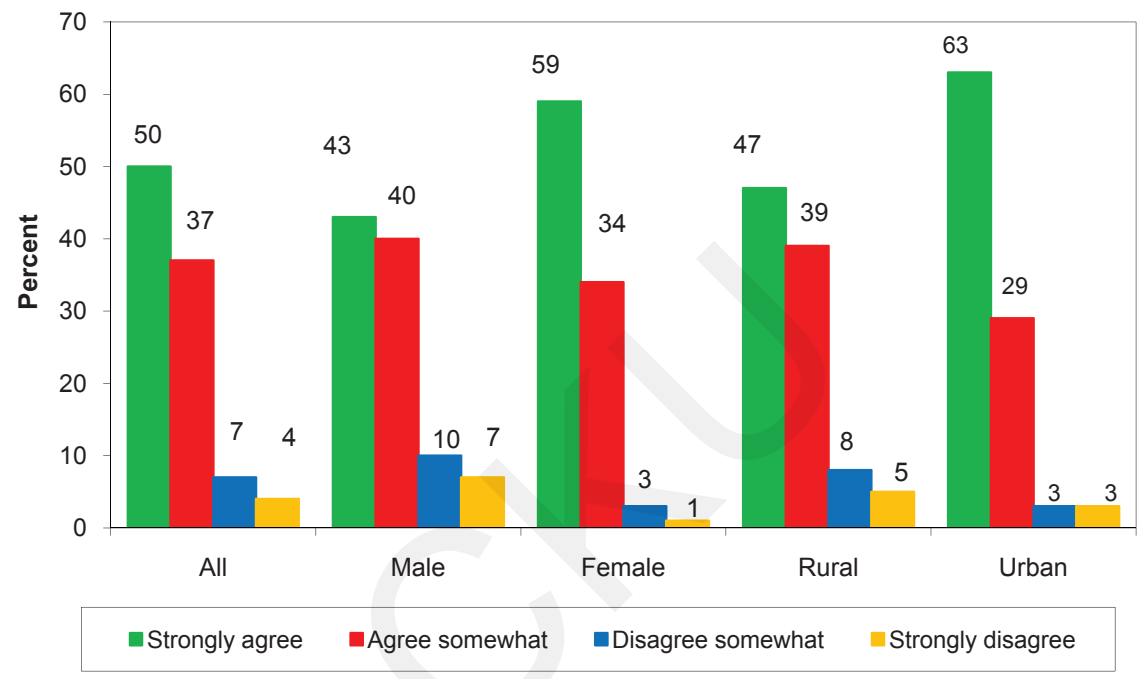

Fig. 11.3

There are variations across communities as well. A higher proportion of Hazara (93\%) Uzbek (91\%), Tajik (90\%) and respondents of other ethnicities (91\%) support equal educational opportunities for women than do Pashtuns (82\%). Twice as many Pashtun respondents (16\%) disagree that women should have equal opportunities in education as respondents from any other ethnic group. These findings closely match those of 2008 and 2009. Support for equal educational opportunities for women is highest in the North West (93\%), Central/Hazarajat (92\%), Central/ Kabul (90\%), and North East $(90 \%)$ regions. However, this falls to below three quarters of respondents $(73 \%)$ in the South West, where around a quarter $(26 \%)$ of respondents opposes such equality, twice as many as in other regions. 
Table 11.2: Some people say that women should have equal opportunities like men in education. Do you agree or disagree with this opinion? (Q-67. Based 6467) BY REGION

\begin{tabular}{|c|c|c|c|c|c|c|c|c|}
\hline & $\begin{array}{c}\text { Central/ } \\
\text { Kabul } \\
(\%)\end{array}$ & $\begin{array}{r}\text { East } \\
(\%)\end{array}$ & $\begin{array}{c}\text { South } \\
\text { East } \\
(\%)\end{array}$ & $\begin{array}{c}\text { South } \\
\text { West } \\
(\%)\end{array}$ & \begin{tabular}{l|} 
West \\
$(\%)$
\end{tabular} & $\begin{array}{c}\text { North } \\
\text { East } \\
(\%)\end{array}$ & $\begin{array}{c}\text { Central/ } \\
\text { Hazarajat } \\
(\%)\end{array}$ & $\begin{array}{c}\text { North } \\
\text { West } \\
(\%)\end{array}$ \\
\hline Strongly agree & 59 & 46 & 43 & 26 & 50 & 52 & 75 & 56 \\
\hline Agree somewhat & 31 & 41 & 44 & 48 & 36 & 38 & 16 & 37 \\
\hline Disagree somewhat & 4 & 8 & 10 & 17 & 6 & 4 & 6 & 4 \\
\hline Strongly disagree & 5 & 3 & 2 & 9 & 5 & 5 & 1 & 2 \\
\hline
\end{tabular}

\subsection{Attitudes toward gender equality: women and employment}

Respondents were also asked to give their opinion on gender equality in relation to employment opportunities. They were asked whether they think women should be allowed to work outside the home. About two-thirds (64\%) say women should be allowed to work outside the home while another third (33\%) say they should not.

Survey findings show that there is also a significant difference between men's and women's attitudes in this regard. More than three quarters of female respondents (77\%) say women should be allowed to work outside the home, compared with just over half $(52 \%)$ of men. Likewise, significantly more urban respondents agree with the statement $(72 \%)$ than do their rural counterparts $(61 \%)$. Support for women working outside the home is also stronger amongst younger age groups. Sixty-five percent of respondents between 18 and 34 years old agree that women should have this opportunity, but this is true for only $58 \%$ of those over 55 . Support also falls as income levels increase. Nearly three quarters of those in the lowest income bracket (earning less than Afs.2,000 per month) say that women should be allowed to work outside the home $(73 \%)$, but this is true for under two-thirds of those earning over Afs. 5000 per month (62\%). This is consistent with the larger proportion of respondents in lower income groups who identify the lack of job opportunity as the biggest problem facing women (see above, 11.1 Women's biggest problem) and is likely to reflect the greater acknowledgement amongst low income families of the potential value of women's paid employment to increase household income. 
Some people say that women should be allowed to work outside the home. What is your opinion about this? (Q-68, Base 6467) BY GENDER AND SETTLEMENT

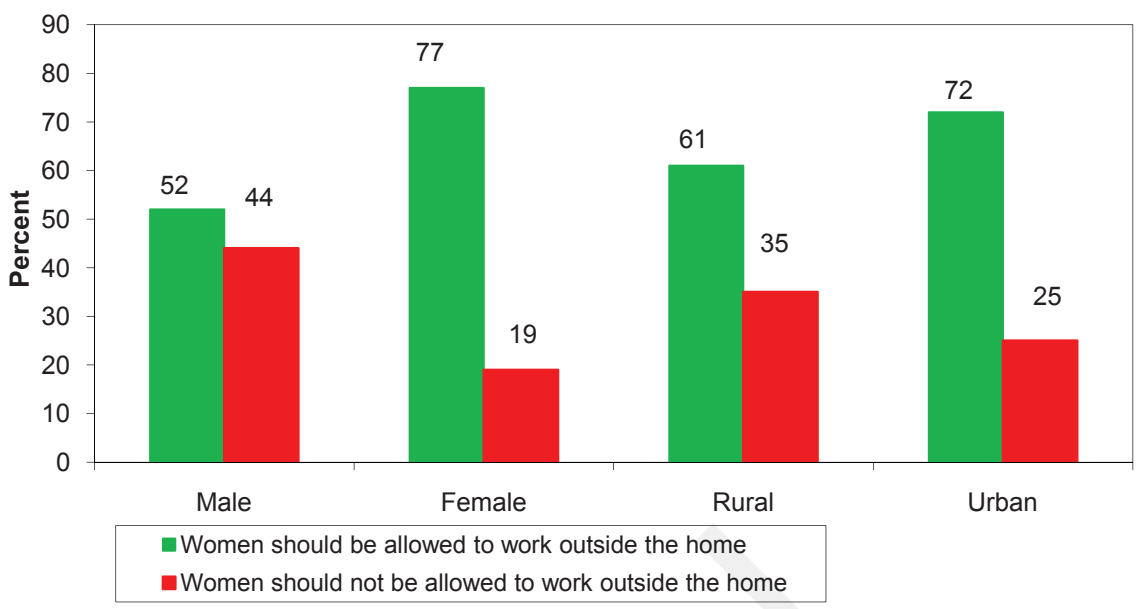

Fig. 11.4

Attitudes also vary at the regional level. As with support for equality in education, the highest levels of support for women working outside the home are in the Central/Hazarajat (84\%), North West (73\%), North East (70\%), Central/Kabul (68\%) and West $(67 \%)$ regions. Opposition is highest in the South West (58\%) and South East (46\%).

Table 11.3: Some people say that women should be allowed to work outside the home. What is your opinion about this? (Q-68, Base 6467)BY REGION

\begin{tabular}{|c|c|c|c|c|c|c|c|c|}
\hline & $\begin{array}{c}\text { Central/ } \\
\text { Kabul } \\
(\%)\end{array}$ & $\begin{array}{l}\text { East } \\
(\%)\end{array}$ & $\begin{array}{c}\text { South } \\
\text { East } \\
(\%)\end{array}$ & $\begin{array}{l}\text { South } \\
\text { West } \\
(\%)\end{array}$ & $\begin{array}{l}\text { West } \\
(\%)\end{array}$ & $\begin{array}{l}\text { North } \\
\text { East } \\
(\%)\end{array}$ & $\begin{array}{c}\text { Central/ } \\
\text { Hazarajat } \\
(\%)\end{array}$ & $\begin{array}{c}\text { North } \\
\text { West } \\
(\%)\end{array}$ \\
\hline $\begin{array}{l}\text { Women should be allowed to } \\
\text { work outside the home }\end{array}$ & 68 & 59 & 50 & 39 & 67 & 70 & 84 & 73 \\
\hline $\begin{array}{l}\text { Women should not be allowed } \\
\text { to work outside the home }\end{array}$ & 28 & 38 & 46 & 58 & 28 & 28 & 14 & 23 \\
\hline
\end{tabular}

However, attitudes are slowly shifting over time. Although the majority of respondents have consistently supported the view that women should be allowed to work outside the home, there has been a steady decline in the proportion of people who agree with this (from $71 \%$ in 2006, 70\% in 2007, 69\% in 2008, 67\% in 2009 and 64\% in 2010). Similarly, opposition to women working outside the home has risen from just over a quarter of respondents in $2006(27 \%)$ to a third (33\%) in 2010. 
Table 11.4: Some people say that women should be allowed to work outside the home. What is your opinion about this? (Q-68) COMPARISON BETWEEN 2006, 2007, 2008, 2009 AND 2010

\begin{tabular}{|l|c|c|c|c|c|} 
& $\begin{array}{c}2006 \\
(\%)\end{array}$ & $\begin{array}{c}2007 \\
(\%)\end{array}$ & $\begin{array}{c}2008 \\
(\%)\end{array}$ & $\begin{array}{c}2009 \\
(\%)\end{array}$ & $\begin{array}{c}2010 \\
(\%)\end{array}$ \\
\hline $\begin{array}{l}\text { Women should be allowed to work outside } \\
\text { the home }\end{array}$ & 71 & 70 & 69 & 67 & 64 \\
\hline $\begin{array}{l}\text { Women should not be allowed to work } \\
\text { outside the home }\end{array}$ & 27 & 28 & 27 & 29 & 33 \\
\hline $\begin{array}{l}\text { Refused } \\
\text { Don't know }\end{array}$ & 1 & 1 & 0 & 1 & 0 \\
\hline
\end{tabular}

Respondents' views on women's independence to work outside the home are clearly correlated with their views on equal opportunities in education. For example, $81 \%$ of respondents who strongly agree that women should have equal opportunities in education also say that women should be allowed to work outside the home. Similarly, 84\% of those who strongly disagree that women should have equal educational opportunities to men also say that women should not be allowed to work outside the home.

Table11.5: Some people say that women should be allowed to work outside the home. What is your opinion about this? (Q-68, Base 6467) BY OPINIONS REGARDING WHETHER WOMEN SHOULD HAVE EQUAL OPPORTUNITIES LIKE MEN IN EDU-

$$
\text { CATION }
$$

\begin{tabular}{|c|c|c|c|c|}
\hline & $\begin{array}{l}\text { Strongly } \\
\text { agree } \\
(\%)\end{array}$ & $\begin{array}{c}\text { Agree } \\
\text { somewhat } \\
(\%)\end{array}$ & $\begin{array}{c}\text { Disagree } \\
\text { somewhat } \\
(\%)\end{array}$ & $\begin{array}{c}\text { Strongly } \\
\text { disagree } \\
(\%)\end{array}$ \\
\hline $\begin{array}{l}\text { Women should be allowed to } \\
\text { work outside the home }\end{array}$ & 81 & 56 & 16 & 14 \\
\hline $\begin{array}{l}\text { Women should not be allowed to } \\
\text { work outside the home }\end{array}$ & 17 & 41 & 80 & 84 \\
\hline Refused & 0 & 1 & 1 & 1 \\
\hline Don't know & 2 & 2 & 3 & 1 \\
\hline
\end{tabular}

\subsection{Women and leadership}

The survey sought to ascertain public attitudes to women in political leadership roles. Respondents were asked whether they think that political leadership positions should be mostly for men, mostly for women, or both men and women should have equal representation in political leadership. A little less than half $(46 \%)$ of respon- 
dents say that both men and women should have equal representation, while $40 \%$ say that leadership positions should be mostly for men. Around one in ten (11\%) say that leadership positions should be mostly for women.

There is a divergence of opinion between male and female respondents on this issue. Women give much greater support for equality of representation than do their male counterparts. Twice as many women $(61 \%)$ as men $(34 \%)$ say there should be equal representation in political leadership. More than half of male respondents $(56 \%)$ believe that political leadership positions should be mostly for men, while only $20 \%$ of female respondents think that leadership positions should be mostly for women.

Opinions also vary between age groups. Among 18-24 year olds almost half (49\%) favor equal leadership positions for both men and women. However, amongst those over 55 the greatest proportion (46\%) prefer political leadership positions to be for men only; in other words, the higher the age of the respondent, the greater their preference for men to be in leadership positions. More respondents in rural areas $(42 \%)$ think that leadership positions should be mostly for men, than those in urban areas (33\%). In urban areas, the majority of respondents (54\%) think that both men and women should have equal representation in political leadership, while only $44 \%$ in rural areas think this.

Do you think that political leadership positions should be mostly for men, mostly for women, or do you think that both men and women should have equal representation in the political leadership? (Q-69, Base 6467)BY GENDER, SETTLEMENTAND AGE

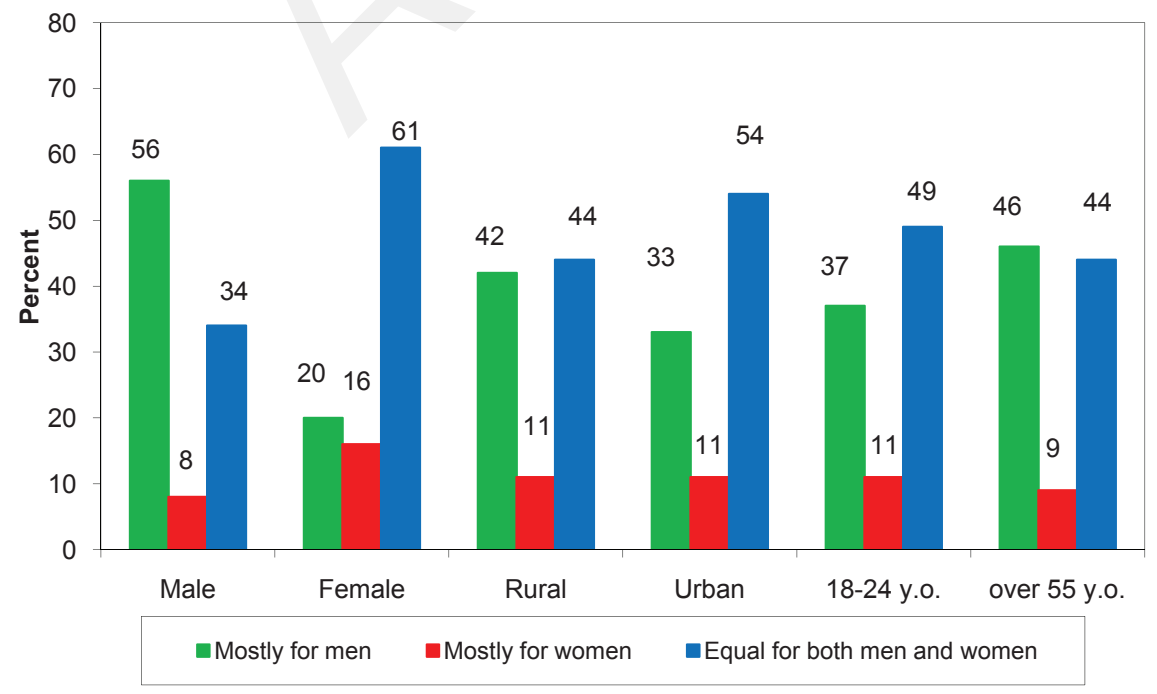

Fig. 11.5 
Support for equal representation of men and women is highest in the Central/Hazarajat (62\%) and North West (61\%) followed by the Central/Kabul (56\%) and North East $(51 \%)$ regions. The regions that register the highest proportion of respondents who say that leadership positions should be for men only are the South East (59\%) and South West (53\%) followed by the East (44\%). These are also the regions that record the highest levels of opposition to women working outside the home (see above 11.3 Attitudes towards gender equality: women and employment). There have been no significant variations in attitudes in this regard since 2006.

Do you think that political leadership positions should be mostly for men, mostly for women, or do you think that both men and women should have equal representation in the political leadership? (Q-69, Base 6467) BY REGION

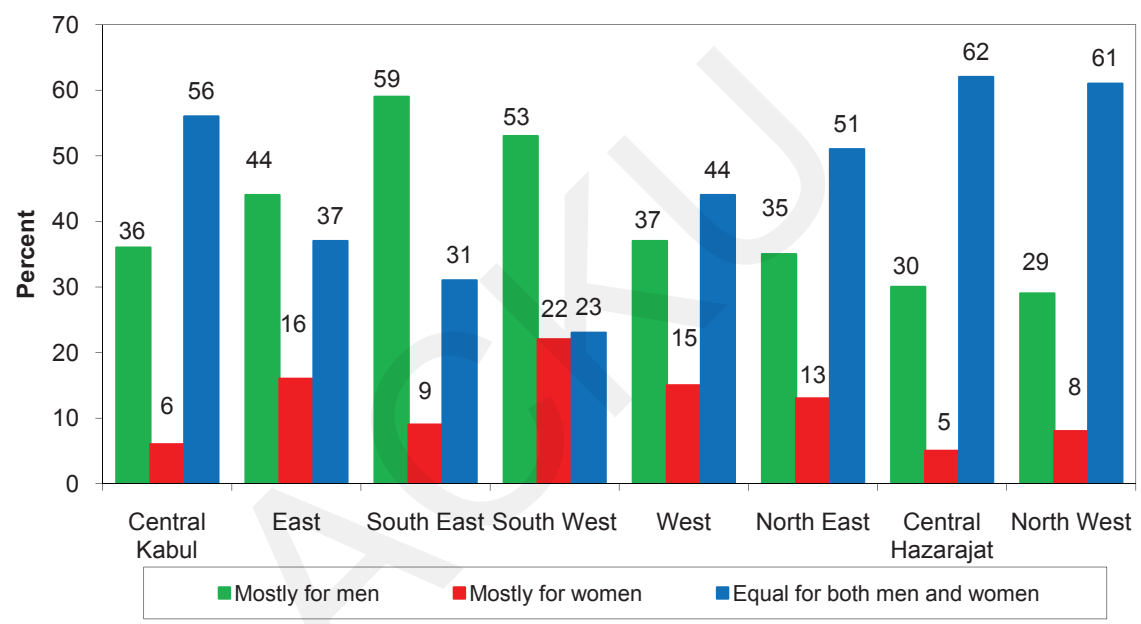

Fig. 11.6

\subsection{Women in representative roles}

In order to investigate public opinion regarding women in political leadership roles in more detail, the survey asked respondents whether they are opposed to being represented by a woman on various bodies from the local to the national level. The responses are summarized in the table below. 
Table11.6: Are you opposed to a woman representing you in the following institutions? (Q-70a-e, Base 6467)

\begin{tabular}{|l|c|c|}
\hline & $\begin{array}{c}\text { Yes } \\
(\mathbf{\%})\end{array}$ & $\begin{array}{c}\text { No } \\
\mathbf{( \% )}\end{array}$ \\
\hline a) In National Parliament & 49 & 49 \\
\hline b) In your Provincial Council & 47 & 51 \\
\hline c) In your Community Development Councils & 43 & 55 \\
\hline d) In your District Development Assembly & 41 & 56 \\
\hline e) In your local Shura or Jirga & 41 & 56 \\
\hline
\end{tabular}

Respondents express the least opposition to being represented by a woman in their District Development Assembly (DDA) (56\% say they have no objection), their local shura or jirga (56\%) and their Community Development Council (CDC) (55\%). Just over half $(51 \%)$ of respondents also say they have no objection to being represented by a woman on the Provincial Council and just under half $(49 \%)$ say the same about being represented by a woman in the national Parliament (49\%), which is the only level for which there is an equal division of opinion between those who object and those who have no objection to being represented by a woman.

There is very little difference in opinion between men and women on this issue. Almost equal proportions of male and female respondents object to being represented by a woman in each of these institutions. The same is true for rural and urban respondents and across different age groups. However there are significant differences between regions and ethnic groups.

Uzbek and respondents from outside the main ethnic groups have the least objection to being represented by a woman in institutions at all levels. Hazara respondents are the least in favor of being represented by a woman. However, the differences of opinion between ethnic groups are much smaller in relation to women representing them in community-level institutions such as Community Development Councils, District Development Assemblies or local shura and jirga. There is greater divergence in relation to representation by a woman in higher level institutions such as the Provincial Council and the national Parliament, where support for female representation drops significantly among Pashtun, Tajik and Hazara respondents. 
Are you opposed to a woman representing you the following institutions? (Q-70a-e, Base 6467) NO Responses - BY ETHNICITY

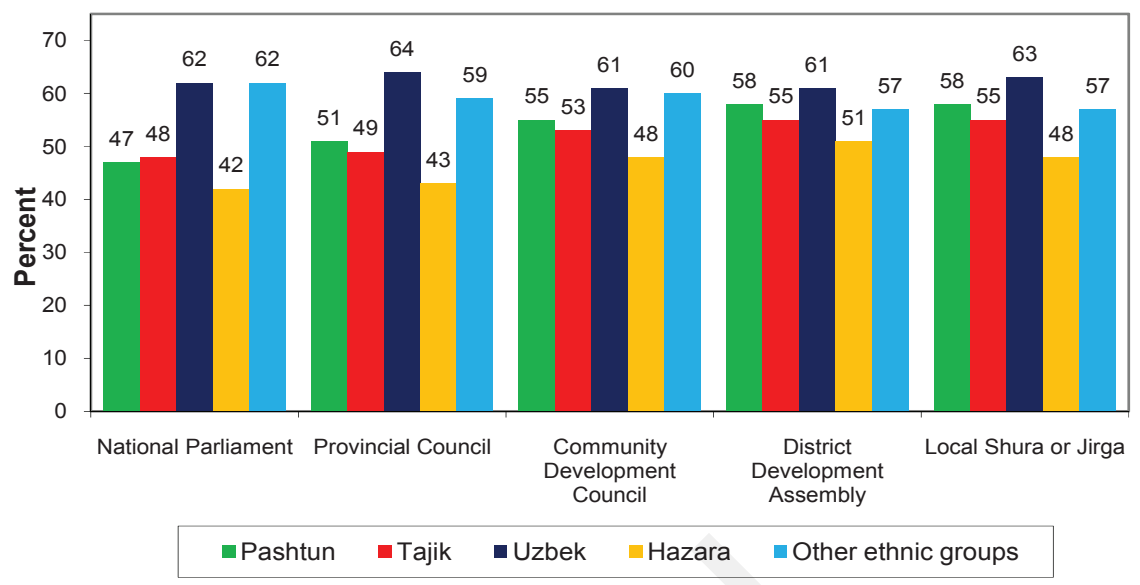

Fig. 11.7

At the regional level, the proportions of respondents who say they have no objection to being represented by a woman in community-level institutions are highest in the North West (60\% for DDAs and CDCs, 59\% for local shura/jirga), East (64\% for DDAs, $58 \%$ for CDCs, $61 \%$ for local shura/jirga), North East (63\% for DDAs, 62\% for CDCs, 66\% for local shura/jirga), South East (62\% for DDAs, $59 \%$ for CDCs, 61\% for local shura/jirga) and South West (59\% for DDAs, 62\% for CDCs, $60 \%$ for local shura/jirga). The majority of respondents also have no objection to being represented by a woman at the Provincial Council level in the North West (61\%), North East (58\%), East (56\%) and South West (56\%), and the majority states the same for the national Parliament in the North West $(61 \%)$, North East (59\%), and East (56\%).

Although the Central/Hazarajat region records amongst the highest levels of support for gender equality in education and employment, only a minority of respondents in this region have no objection to being represented by a woman in institutions at almost all levels, except the District Development Assembly (51\%). This is also the case in the Central/Kabul (50\% for the District Development Assembly) and West (below 50\% for all institutions). 
Table11.7 Are you opposed to a woman representing you in the following institutions? (Q-70a-e, Base 6467) NO Responses - BY REGION

\begin{tabular}{|l|c|c|c|c|c|c|c|c|}
\hline & $\begin{array}{c}\text { Central/ } \\
\text { Kabul } \\
(\mathbf{\%})\end{array}$ & $\begin{array}{c}\text { East } \\
\mathbf{( \% )}\end{array}$ & $\begin{array}{c}\text { South } \\
\text { East } \\
\mathbf{( \% )}\end{array}$ & $\begin{array}{c}\text { South } \\
\text { West } \\
\mathbf{( \% )}\end{array}$ & $\begin{array}{c}\text { West } \\
\mathbf{( \% )}\end{array}$ & $\begin{array}{c}\text { North } \\
\text { East } \\
\mathbf{( \% )}\end{array}$ & $\begin{array}{c}\text { Central/ } \\
\text { Hazarajat } \\
\mathbf{( \% )}\end{array}$ & $\begin{array}{c}\text { North } \\
\text { West } \\
\mathbf{( \% )}\end{array}$ \\
\hline National Parliament & 46 & 56 & 40 & 47 & 39 & 59 & 49 & 61 \\
\hline $\begin{array}{l}\text { Provincial Council } \\
\text { Community Development }\end{array}$ & 48 & 56 & 43 & 56 & 39 & 58 & 47 & 61 \\
\hline $\begin{array}{l}\text { Council (CDC) } \\
\text { District Development } \\
\text { Assembly (DDA) }\end{array}$ & 50 & 64 & 62 & 59 & 48 & 63 & 51 & 60 \\
\hline Local Shura or Jirga & 49 & 61 & 61 & 60 & 47 & 66 & 47 & 59 \\
\hline
\end{tabular}

Support for female representation has remained basically stable in recent years. In 2009, which was an election year for Provincial Councils, there was a clear drop in the proportion of respondents who said they have no objection to being represented by a woman at this level (from 59\% in 2008 to 49\% in 2009). However this figure has risen again slightly in 2010 to $51 \%$. There has not been a corresponding drop in support for women in representative roles in the national Parliament, despite 2010 being a year for parliamentary elections, although the proportion of respondents who have no objections to being represented by a female MP continues to decline slightly (from 55\% in 2008 to 50\% in 2009 and 49\% in 2010).

Table11.8: Proportion of respondents who are not opposed to being represented by a woman in the following organizations - NO responses only - (Q-70a-e) COMPARISON BETWEEN 2007, 2008, 2009 AND 2010

\begin{tabular}{|l|c|c|c|c|} 
& $\begin{array}{c}\mathbf{2 0 0 7} \\
(\%)\end{array}$ & $\begin{array}{c}\mathbf{2 0 0 8} \\
\mathbf{( \% )}\end{array}$ & $\begin{array}{c}\mathbf{2 0 0 9} \\
\mathbf{( \% )}\end{array}$ & $\begin{array}{c}\mathbf{2 0 1 0} \\
\mathbf{( \% )}\end{array}$ \\
\hline a) In National Parliament & 55 & 57 & 50 & 49 \\
\hline b) In your Provincial Council & 58 & 59 & 49 & 51 \\
\hline c) In your Community Development Councils & 58 & 58 & 52 & 55 \\
\hline d) In your District Development Assembly & 59 & 57 & 54 & 56 \\
\hline e) In your local Shura or Jirga & 56 & 58 & 53 & 56 \\
\hline
\end{tabular}




\section{Access to Information}

Since 2006, the survey has been exploring how Afghan people access and receive information. This year the survey again examined listenership of radio, viewership of television, readership of newspapers/magazines, and household ownership of various types of communications technologies, such as radio, television, fixed phone lines, mobile phones and computers in households. The survey also assessed the preferences of Afghans for receiving information through these means and other informal communication systems.

\subsection{Access to communications technology}

As in previous years, radio is the most accessible media for Afghan households. Slightly more than four-fifths $(82 \%)$ of respondents say they have radios in functioning order in their household, and there is little difference in access to radio between rural (82\%) and urban $(79 \%)$ areas. However, other communication technologies are much more accessible to urban residents than to those living in rural areas. For instance, $88 \%$ of urban households have functioning TV sets while only $28 \%$ of rural households have access to television. The same is true for mobile phones. More than four-fifths $(86 \%)$ of urban respondents say they have mobile phones while this is true for just over half $(52 \%)$ of rural respondents. Although, only a small proportion of Afghan households own a computer ( $9 \%)$, seven times more urban respondents $(28 \%)$ than rural respondents $(4 \%)$ say they have one. Ownership of fixed phone lines is extremely rare in Afghanistan.

Table 12.1: Proportion of respondents who have the following communications technologies in functioning order in their households (Q-1) ALL, RURAL AND URBAN SETTLEMENT (Q-1, Base 6467)

\begin{tabular}{|l|c|c|c|}
\hline & $\begin{array}{c}\text { All } \\
(\%)\end{array}$ & $\begin{array}{c}\text { Rural } \\
(\%)\end{array}$ & $\begin{array}{c}\text { Urban } \\
(\%)\end{array}$ \\
\hline Radio & 82 & 82 & 79 \\
\hline TV set & 41 & 28 & 88 \\
\hline Mobile phone & 59 & 52 & 86 \\
\hline Computer & 9 & 4 & 28 \\
\hline
\end{tabular}

Ownership of all kinds of communications technology rises with both income and educational levels. More than four-fifths (84\%) of all households earning between Afs.3,000 and Afs.5,000 a month own a radio, but this is true for just over two-thirds (68\%) of households earning under Afs.2,000. This disparity highlights the challenges of providing information through technological means to the poorer segments of Afghan society. 
Radio ownership is highest in the South East (97\%), East (92\%) and South West $(92 \%)$. It is relatively low in the Central/Hazarajat (62\%) and North West (63\%) regions. Access to television is highest in the Central/Kabul region (66\%) followed by the West (50\%) and North East (39\%). Mobile telephone penetration is also highest in the Central/Kabul region (85\%) followed by the East (69\%), South East (66\%), and North West (60\%). The Central/Kabul region also has a significantly higher proportion of households that own a computer $(22 \%)$ than any other region.

Table 12.2: Regional comparison of ownership of communications technologies (Q-1, Base 6467)

\begin{tabular}{|l|c|c|c|c|c|c|c|c|} 
& $\begin{array}{c}\text { Central/ } \\
\text { Kabul } \\
\mathbf{( \% )}\end{array}$ & $\mathbf{E} \mathbf{( \% )}$ & $\begin{array}{c}\text { South } \\
\text { East } \\
\mathbf{( \% )}\end{array}$ & $\begin{array}{c}\text { South } \\
\text { West } \\
\mathbf{( \% )}\end{array}$ & $\begin{array}{c}\text { West } \\
\mathbf{( \% )}\end{array}$ & $\begin{array}{c}\text { North } \\
\text { East } \\
\mathbf{( \% )}\end{array}$ & $\begin{array}{c}\text { Central/ } \\
\text { Hazarajat } \\
\mathbf{( \% )}\end{array}$ & $\begin{array}{c}\text { North } \\
\text { West } \\
\mathbf{( \% )}\end{array}$ \\
\hline Radio & 81 & 92 & 97 & 92 & 84 & 77 & 62 & 63 \\
\hline TV set & 66 & 21 & 30 & 24 & 50 & 39 & 29 & 34 \\
\hline Mobile phone & 85 & 69 & 66 & 33 & 42 & 48 & 31 & 60 \\
\hline Computer & 22 & 4 & 6 & 10 & 9 & 2 & $*$ & 3 \\
\hline
\end{tabular}

Despite the fact that radio continues to be the most accessible form of communications technology in Afghanistan, ownership of functioning radios has declined slightly over time (from 88\% in 2007 to $84 \%$ in 2008, 81\% in 2009 and $82 \%$ in 2010). On the other hand, the proportion of respondents who own television sets has risen slightly (from 37\% in 2007 to $38 \%$ in 2008, 41\% in 2009 and 2010). However, the most impressive increase has been seen in mobile phone ownership which has risen from $42 \%$ in 2007 to $59 \%$ in 2010 . Computer ownership is also rising. The proportion of respondents who report that they own a computer has almost doubled between 2008 (5\%) and 2010 (9\%) although the proportions remain very small compared to other forms of communications technology.

Table 12.3: Proportion of respondents who have the following communications technologies in functioning order in their households (Q-1) COMPARISON BETWEEN 2007, 2008, 2009 AND 2010

\begin{tabular}{|l|c|c|c|c|}
\hline & $\begin{array}{c}2007 \\
(\%)\end{array}$ & $\begin{array}{c}\mathbf{2 0 0 8} \\
\mathbf{( \% )}\end{array}$ & $\begin{array}{c}\mathbf{2 0 0 9} \\
(\mathbf{\%})\end{array}$ & $\begin{array}{c}\mathbf{2 0 1 0} \\
\mathbf{( \% )}\end{array}$ \\
\hline Radio & 88 & 84 & 81 & 82 \\
\hline TV set & 37 & 38 & 41 & 41 \\
\hline Mobile phone & 42 & 40 & 52 & 59 \\
\hline Computer & - & 5 & 6 & 9 \\
\hline
\end{tabular}




\subsection{Radio listenership}

The survey attempted to examine the use of different media. Respondents were first asked whether they listen to radio programs. A large majority (79\%) say they listen to radio programs while $21 \%$ say they do not. More men $(86 \%)$ listen to the radio than women $(70 \%)$; likewise, more rural residents $(80 \%)$ listen to the radio than urban residents $(74 \%)$.

Do you listen to radio programs? (W-1, Base 6467)

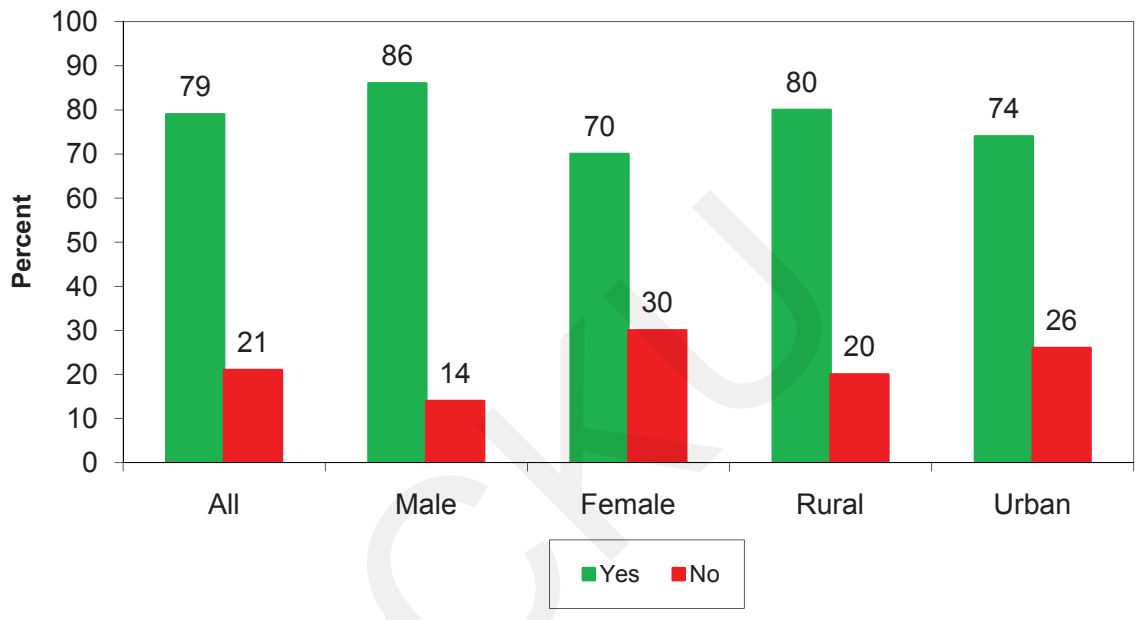

Fig 12.1

Radio listenership is lower in low income households. Households earning less than Afs.2000 a month listen to the radio the least (64\%), while those earning more than Afs.10,000 (81\%) listen the most. This is consistent with radio ownership figures which are correspondingly higher for household with higher incomes (over Afs.10,000 per month) (86\%) than for those in the lowest income bracket (less than Afs. 2000 per month) (68\%). Just 3\% of respondents who say they do not own a radio in their household say that they sometimes listen to the radio, suggesting they have some limited access to this means of communication outside the home.

Radio ownership affects listenership at the regional level as well. Respondents in the South East report the highest levels of radio ownership (97\%) and are also those who listen to the radio the most (95\%). The lowest proportion of radio ownership is in the Central/Hazarajat (62\%) and North West (63\%) regions. These are also the regions that record the lowest radio listenership, (53\% in the Central/Hazarajat and $59 \%$ in the North West). 
Table 12.4: Comparison of ownership and listenership of radio (Q-1 a \& $W-1$, Base 6467) $B Y$ REGION AND ALL

\begin{tabular}{|l|c|c|c|c|c|c|c|c|c|} 
& All & $\begin{array}{c}\text { Central/ } \\
\text { Kabul } \\
\mathbf{( \% )}\end{array}$ & $\begin{array}{l}\text { East } \\
\mathbf{( \% )}\end{array}$ & $\begin{array}{c}\text { South } \\
\text { East } \\
\mathbf{( \% )}\end{array}$ & $\begin{array}{c}\text { South } \\
\text { West } \\
\mathbf{( \% )}\end{array}$ & $\begin{array}{c}\text { West } \\
\mathbf{( \% )}\end{array}$ & $\begin{array}{c}\text { North } \\
\text { East } \\
\mathbf{( \% )}\end{array}$ & $\begin{array}{c}\text { Central } \\
\text { Hazarajat } \\
\mathbf{( \% )}\end{array}$ & $\begin{array}{l}\text { North } \\
\text { West } \\
\mathbf{( \% )}\end{array}$ \\
\hline Radio Ownership & 82 & 81 & 92 & 97 & 92 & 84 & 77 & 62 & 63 \\
\hline Radio Listenership & 79 & 79 & 92 & 95 & 90 & 77 & 77 & 53 & 59 \\
\hline
\end{tabular}

Respondents were then asked how often they use the radio to get news and information about current events. Forty-three percent say they use it every day or almost every day for this purpose and another $21 \%$ say they get information and news from the radio three or four days a week. Seventeen percent of respondents say they never use the radio for this purpose.

How often do you use the radio to get news and information about current events? (Q-3g, Base 6467)

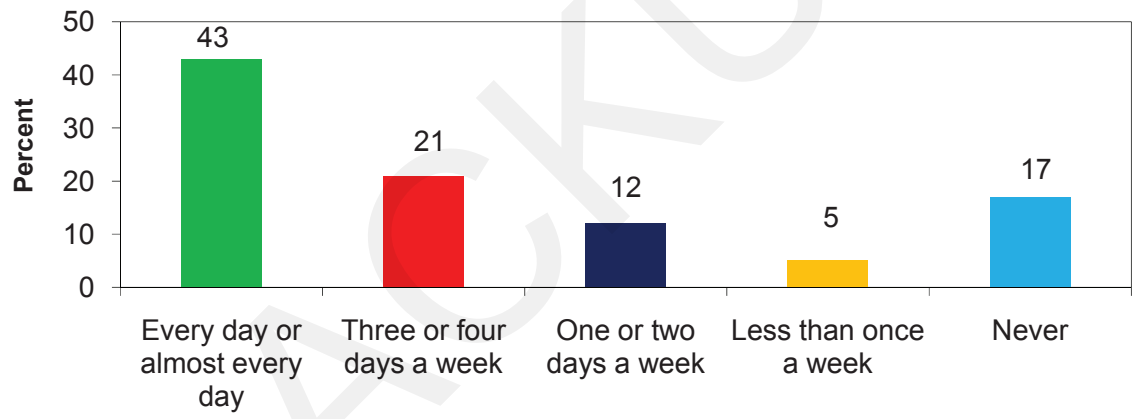

Fig 12.2

There has been little change in the use of radio to get news and information on current events since 2008 .

\subsection{Television viewership}

The survey then asked about television viewership. Respondents were asked whether they watch television programs. The majority (59\%) say they do not watch television programs while $40 \%$ say that they do. Television viewership is much higher in urban $(87 \%)$ than rural $(28 \%)$ areas. This is consistent with much higher levels of television ownership in urban areas. Unlike the radio, more women (43\%) report that they watch television than men $(39 \%)$. 
Do you watch television programs? (W-2, Base 6467)

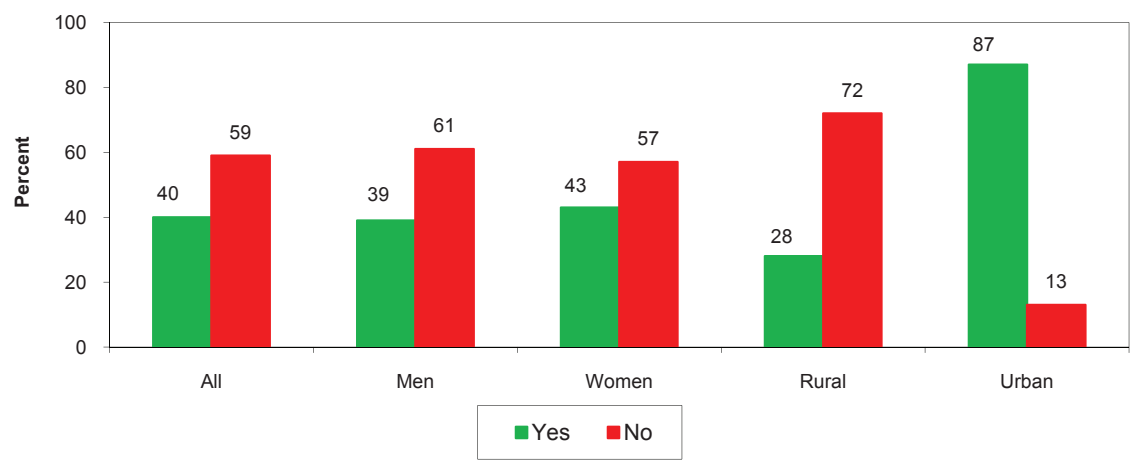

Fig 12.3

Viewership of television also rises steadily with both income and educational level. About half $(50 \%)$ of all households earning over Afs.10,000 a month watch television, but this is true for less than one-third (31\%) of households earning under Afs.2,000. Television viewing is also much higher in urban areas where television ownership is high, than in rural areas where the majority of respondents do not own a TV. However, $8 \%$ of those who do not own a television set in their household say they do watch television, which suggests a small proportion of those without private access to TV have access through other means, such as family and friends or broadcasts in public places.

Again television viewership is highest in areas where more people own television sets. For instance, Central/Kabul is the region that records the highest ownership of televisions $(66 \%)$ and is also the region that records the highest television viewership (64\%). Whereas, three quarters $(75 \%)$ of respondents in the South West do not watch television, largely because $76 \%$ do not own a television set.

Table 12.5: Comparison of ownership of TV set and viewership of television (Q-1b\&W2, Base 6467) BY REGION AND ALL

\begin{tabular}{|c|c|c|c|c|c|c|c|c|c|}
\hline & $\begin{array}{l}\text { All } \\
(\%)\end{array}$ & $\begin{array}{c}\text { Central/ } \\
\text { Kabul } \\
(\%)\end{array}$ & $\begin{array}{l}\text { East } \\
(\%)\end{array}$ & $\begin{array}{c}\text { South } \\
\text { East } \\
(\%)\end{array}$ & $\begin{array}{c}\text { South } \\
\text { West } \\
(\%)\end{array}$ & $\begin{array}{l}\text { West } \\
(\%)\end{array}$ & $\begin{array}{c}\text { North } \\
\text { East } \\
(\%)\end{array}$ & $\begin{array}{c}\text { Central } \\
\text { Hazarajat } \\
(\%)\end{array}$ & $\begin{array}{c}\text { North } \\
\text { West } \\
(\%)\end{array}$ \\
\hline Ownership of TV set & 41 & 66 & 21 & 30 & 24 & 50 & 39 & 29 & 34 \\
\hline Viewership of TV & 40 & 64 & 22 & 30 & 24 & 47 & 39 & 31 & 33 \\
\hline
\end{tabular}


Respondents were then asked how often they use the television to get news and information about current events. About half of respondents (51\%) say they never watch television. A much higher proportion of rural respondents say this $(62 \%)$ than urban respondents $(10 \%)$. Around a quarter $(27 \%)$ say they watch television every day or almost every day to get news and information.

How often do you use the television to get news and information about current events? (Q-3h, Base 6467) ALL AND BY RURAL-URBAN

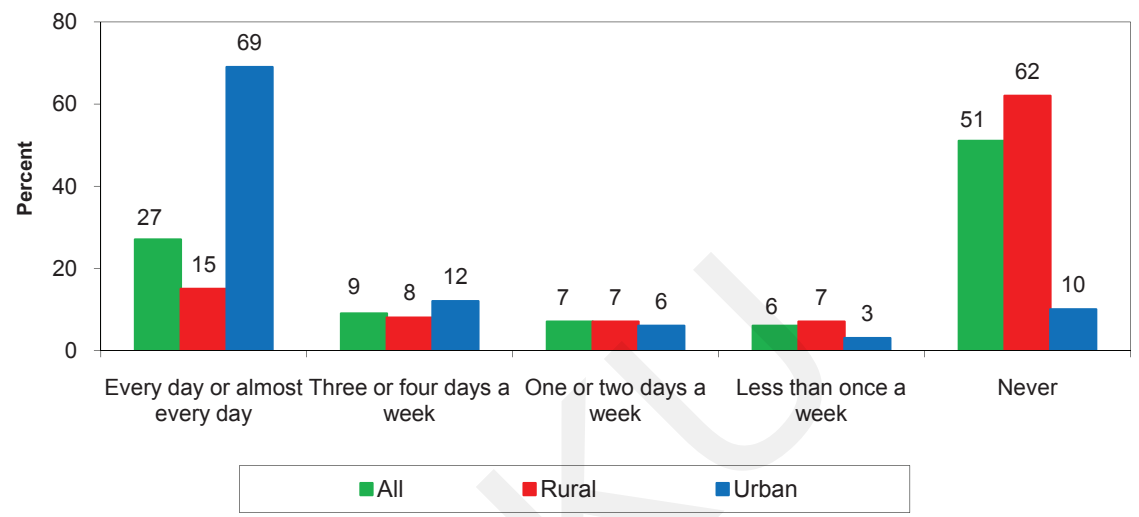

Fig 12.4

Television viewing patterns have not changed in a significant manner since 2006.

\subsection{Sources of information for news and current events}

In order to understand the usage of various sources of information, the survey asked all respondents which sources they use most often to get news and information. Just under half $(46 \%)$ of the respondents use radio while just over a quarter $(28 \%)$ use television to get news and information. Around one in five respondents $(19 \%)$ depend on friends and family to receive news and information.

There is a significant variation between urban and rural areas. About three quarters of respondents in urban areas $(73 \%)$ most often use television as the preferred source for news and information, which is six times higher than their rural counterparts $(16 \%)$. In contrast, almost three times as many respondents in rural areas use radio (54\% compared to $18 \%$ in urban areas), friends and family ( $22 \%$ compared to $7 \%$ in urban areas), and mosques (7\% compared to $1 \%$ in urban areas) to get news and information. 
Which of the following sources do you use most often for news and information? (W-3, Base 6467)

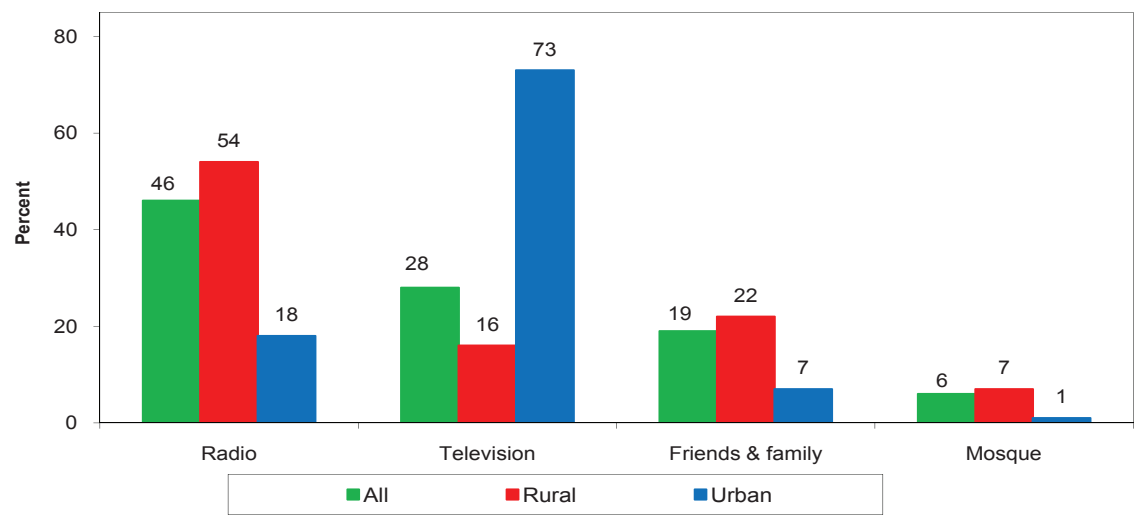

Fig 12.5

There are large differences across regions on the sources used to access news and information. Radio use for this purpose is highest in the East (68\%), South West $(68 \%)$ and South East (61\%), but is used by barely a third of respondents in the Central/ Hazarajat (29\%), Central/Kabul (32\%) and North West (33\%) regions.

Not surprisingly, the highest proportion of respondents mentioning television as their source of news and information is in the Central/Kabul region (56\%). This is the only region where more respondents get their news and information from television rather than radio. It is also the region that records the lowest use of friends and family $(9 \%)$ and the mosque $(2 \%)$ as sources of news and information.

Friends and family constitute the most important source of news and information in the Central/Hazarajat region (48\%). This suggests that the high proportion of respondents in this region with no access to radio and television rely on friends and family who can access these means of communication to get information about current events. Around one in ten respondents use the mosque as a source of news and information in the South East (9\%), West (9\%) and North West (9\%) regions.

Table 12.6: Which of the following sources do you use most often for news and information? $(W-3$, Base 6467) BY REGION AND ALL

\begin{tabular}{|c|c|c|c|c|c|c|c|c|c|}
\hline & $\begin{array}{l}\text { All } \\
(\%)\end{array}$ & $\begin{array}{c}\text { Central/ } \\
\text { Kabul } \\
(\%)\end{array}$ & \begin{tabular}{c|} 
East \\
$(\%)$
\end{tabular} & $\begin{array}{c}\text { South } \\
\text { East } \\
(\%)\end{array}$ & $\begin{array}{l}\text { South } \\
\text { West } \\
(\%)\end{array}$ & $\begin{array}{l}\text { West } \\
(\%)\end{array}$ & $\begin{array}{c}\text { North } \\
\text { East } \\
(\%)\end{array}$ & $\begin{array}{c}\text { Central } \\
\text { Hazarajat } \\
(\%)\end{array}$ & $\begin{array}{c}\text { North } \\
\text { West } \\
(\%)\end{array}$ \\
\hline Radio & 46 & 32 & 68 & 61 & 68 & 41 & 47 & 29 & 33 \\
\hline Television & 28 & 56 & 9 & 15 & 12 & 33 & 26 & 18 & 22 \\
\hline Friends \& family & 19 & 9 & 15 & 15 & 13 & 16 & 22 & 48 & 36 \\
\hline Mosque & 6 & 2 & 6 & 9 & 6 & 9 & 4 & 4 & 9 \\
\hline
\end{tabular}




\subsection{Sources of information on local events}

The survey also endeavored to learn about public preferences regarding sources of information on local events. Respondents were asked to identify who, outside their families, they ask if they want to find out about something important happening in their communities.

Again in 2010 the findings show that respondents prefer to get such information from personal acquaintances rather than leadership figures within their community. Around a quarter of respondents (26\%) mention friends and another fifth (20\%) mention neighbors or villagers. Only around one in ten say they prefer to get information about local events from village chiefs/community leaders (12\%) or mullahs $(11 \%)$.

Preferences for getting information about local events vary across regions. The highest proportions of respondents who get news and information about local events through personal networks (i.e. friends and neighbors/villagers) are in the Central/Hazarajat (58\%) and North West (54\%). Receiving news and information about local events from influential people (i.e. community leaders and mullahs) is most common in the East (32\%), South West (29\%) and West (26\%). The highest proportion of respondents who get this information from local or international radio is in South East (30\%).

Table 12.7: If you wanted to find out about something important happening in your community, who, outside your family, do you ask? (Q-2)

\begin{tabular}{|c|c|c|c|c|c|c|c|c|c|}
\hline & $\begin{array}{l}\text { All } \\
(\%)\end{array}$ & $\begin{array}{c}\text { Central/ } \\
\text { Kabul } \\
(\%)\end{array}$ & $\begin{array}{l}\text { East } \\
(\%)\end{array}$ & $\begin{array}{c}\text { South } \\
\text { East } \\
(\%)\end{array}$ & $\begin{array}{c}\text { South } \\
\text { West } \\
(\%)\end{array}$ & $\begin{array}{l}\text { West } \\
(\%)\end{array}$ & $\begin{array}{c}\text { North } \\
\text { East } \\
(\%)\end{array}$ & $\begin{array}{c}\text { Central/ } \\
\text { Hazarajat } \\
(\%)\end{array}$ & $\begin{array}{c}\text { North } \\
\text { West } \\
(\%)\end{array}$ \\
\hline $\begin{array}{l}\text { Neighbor / villagers } \\
\text { and friends }\end{array}$ & 46 & 46 & 37 & 39 & 34 & 49 & 47 & 58 & 54 \\
\hline $\begin{array}{l}\text { Village Chief / } \\
\text { Community leaders } \\
\text { and Mullahs }\end{array}$ & 23 & 19 & 32 & 20 & 29 & 26 & 20 & 20 & 23 \\
\hline $\begin{array}{l}\text { Local Afghan radio } \\
\text { and International } \\
\text { Radio (such as } \\
\text { BBC, VOA, etc) }\end{array}$ & 20 & 18 & 22 & 30 & 25 & 15 & 24 & 16 & 14 \\
\hline
\end{tabular}

The proportion of respondents who say they prefer to ask personal acquaintances such as neighbors or villagers to get information on local events has been falling over the years. In 2006, around one-third (34\%) of respondents said their preference for 
getting news about the local community was neighbors/friends. The figure fell to $30 \%$ in 2007, 25\% in 2008, and to around one-fifth in 2009 (21\%) and 2010 (20\%). On the other hand, the popularity of both local and international radio stations as a source of local information has significantly increased between 2006 and 2010. Indeed twice as many respondents say they use local Afghan radio stations to get news about local events in $2010(10 \%)$ as in $2008(5 \%)$.

Table 12.8: If you wanted to find out about something important happening in your community, who, outside your family, do you ask? (Q-2) COMPARISON BETWEEN 2006, 2007, 2008, 2009 AND 2010

\begin{tabular}{|l|c|c|c|c|c|} 
& $\begin{array}{c}\mathbf{2 0 0 6} \\
\mathbf{( \% )}\end{array}$ & $\begin{array}{c}\mathbf{2 0 0 7} \\
\mathbf{( \% )}\end{array}$ & $\begin{array}{c}\mathbf{2 0 0 8} \\
\mathbf{( \% )}\end{array}$ & $\begin{array}{c}\mathbf{2 0 0 9} \\
\mathbf{( \% )}\end{array}$ & $\begin{array}{c}\mathbf{2 0 1 0} \\
\mathbf{( \% )}\end{array}$ \\
\hline Friends & 28 & 30 & 26 & 23 & 26 \\
\hline Neighbors/villagers & 34 & 30 & 25 & 21 & 20 \\
\hline Village chiefs/community leaders & 15 & 13 & 14 & 17 & 12 \\
\hline Mullahs & 6 & 11 & 10 & 13 & 11 \\
\hline International radio stations & 0 & 0 & 8 & 9 & 10 \\
\hline Local Afghan radio stations & 0 & 0 & 5 & 7 & 10 \\
\hline
\end{tabular}

The survey also attempted to ascertain how often people use different forms of print and electronic media such as newspaper, magazines, internet and SMS text messaging, and how often they use oral means such as meetings in the community and sermons in mosques as their major source of information about current events. The great majority of respondents say they never use newspapers $(81 \%)$, magazines $(83 \%)$, the internet $(98 \%)$ or SMS text messaging $(74 \%)$ for this purpose. Low access to communications technologies and relatively low level of literacy among the Afghan population are likely to be contributing factors.

However, the use of oral communication to get news and information is high. More than half of respondents use meetings in the community (57\%) and sermons in mosques $(61 \%)$ for this purpose. This shows that traditional means of information dissemination continue to remain important in Afghan society. 
Table 12.9: How often do you use the following sources to get news and information about current events? (Q-3a-f, Base 6467)

\begin{tabular}{|l|c|c|c|c|c|c|} 
& $\begin{array}{r}\text { Every day or } \\
\text { almost every } \\
\text { day } \\
(\mathbf{0})\end{array}$ & $\begin{array}{r}\text { Every day or } \\
\text { almost every } \\
\text { day } \\
\mathbf{( \% )}\end{array}$ & $\begin{array}{c}\text { Three or } \\
\text { four days } \\
\text { a week } \\
\mathbf{( \% )}\end{array}$ & $\begin{array}{c}\text { One or } \\
\text { two days } \\
\text { a week } \\
\mathbf{( \% )}\end{array}$ & $\begin{array}{c}\text { Less than } \\
\text { once per } \\
\text { week } \\
(\%)\end{array}$ & Never \\
\hline $\begin{array}{l}\text { a) Newspapers } \\
\text { b) Magazines }\end{array}$ & 2 & 2 & 3 & 4 & 9 & 81 \\
\hline c) The Internet & 1 & 1 & 2 & 4 & 9 & 83 \\
\hline $\begin{array}{l}\text { d) SMS text } \\
\text { messaging }\end{array}$ & 1 & 0 & 0 & 0 & 0 & 98 \\
\hline $\begin{array}{l}\text { e) Meetings in } \\
\text { your community }\end{array}$ & 4 & 1 & 3 & 5 & 16 & 74 \\
\hline $\begin{array}{l}\text { f) Sermons at } \\
\text { your mosque }\end{array}$ & 14 & 13 & 16 & 24 & 42 & 42 \\
\hline
\end{tabular}

Over time, the use of SMS text messaging to access news and information has risen dramatically (from $9 \%$ in 2007 to $10 \%$ in 2008, to $19 \%$ in 2009 and $25 \%$ in 2010). This is consistent with the significant rise in mobile phone ownership over this same period. While $42 \%$ of respondents owned mobile phones in $2007,59 \%$ own them in 2010 (see Table 12.3). The use of newspapers and magazines has fluctuated between 2007 and 2010. However there has been an increase in the proportion of respondents who prefer to get local news by attending meetings in the community or through sermons in mosques. The figures for both of these sources in 2010 are the highest recorded since 2007.

Table 12.10: Proportion of those who use the following sources to get news and information about current events (Q-3a-f, Base 6467) COMPARISON BETWEEN 2007, 2008, 2009 AND 2010

\begin{tabular}{|l|c|c|c|c|} 
& $\begin{array}{c}\mathbf{2 0 0 7} \\
\mathbf{( \% )}\end{array}$ & $\begin{array}{c}\mathbf{2 0 0 8} \\
\mathbf{( \% )}\end{array}$ & $\begin{array}{c}\mathbf{2 0 0 9} \\
\mathbf{( \% )}\end{array}$ & $\begin{array}{c}\mathbf{2 0 1 0} \\
\mathbf{( \% )}\end{array}$ \\
\hline a) Newspapers & 25 & 19 & 24 & 18 \\
\hline b) Magazines & 22 & 15 & 22 & 16 \\
\hline c) The Internet & 4 & 2 & 0 & 0 \\
\hline d) SMS text messaging & 9 & 10 & 19 & 25 \\
\hline e) Meetings in your community & 51 & 48 & 53 & 57 \\
\hline f) Sermons at your mosque & 56 & 55 & 47 & 61 \\
\hline
\end{tabular}




\section{Appendix 1: Target Demographics}

A total of 6467 respondents were surveyed in the study, out of which $5076(79 \%)$ were from rural areas and 1390 (21\%) were from urban areas. Of all respondents interviewed, 56\% were male and 44\% were female. The following tables provide demographic and socio-economic details of the respondents including a rural-urban breakdown. They also provide the employment status, occupation, educational status, income status and marital status of the respondents.

\section{Gender and Region}

\begin{tabular}{|c|c|c|c|}
\hline \multirow{2}{*}{ Characteristics } & All & Rural & Urban \\
\hline & 6467 & 5076 & 1390 \\
\hline Gender & $(\%)$ & $(\%)$ & $(\%)$ \\
\hline Male & 56 & 57 & 50 \\
\hline Female & 44 & 43 & 50 \\
\hline Region & $\%$ & $\%$ & $\%$ \\
\hline Central/Kabul & 23 & 14 & 54 \\
\hline South East & 11 & 13 & 2 \\
\hline East & 10 & 12 & 3 \\
\hline North East & 15 & 16 & 10 \\
\hline North West & 14 & 15 & 12 \\
\hline West & 14 & 15 & 9 \\
\hline South West & 11 & 12 & 8 \\
\hline Central/Hazarajat & 4 & 4 & 1 \\
\hline
\end{tabular}

\section{Ethnicity Status}

\begin{tabular}{|l|c|c|c|c|}
\hline & \multicolumn{1}{c|}{ Ethnicity } & All & Rural & Urban \\
\hline & Base: all respondents & $\mathbf{6 4 6 7}$ & $\mathbf{5 0 7 6}$ & $\mathbf{1 3 9 0}$ \\
\hline Pashtun & $\mathbf{( \% )}$ & $\mathbf{( \% )}$ & $\mathbf{( \% )}$ \\
\hline Tajik & 42 & 46 & 27 \\
\hline Uzbek & 31 & 25 & 52 \\
\hline Hazara & 9 & 9 & 7 \\
\hline Turkmen & 10 & 10 & 12 \\
\hline Baloch & 2 & 3 & 1 \\
\hline Kirghiz & 1 & 1 & 1 \\
\hline Nuristani & $*$ & $*$ & 0 \\
\hline Aimak & 1 & 1 & 0 \\
\hline Arab & 2 & 2 & $*$ \\
\hline Pashaye & 2 & 2 & 1 \\
\hline
\end{tabular}




\section{Employment Status and Age Group}

\begin{tabular}{|l|c|c|c|c|}
\hline \multirow{2}{*}{\begin{tabular}{l} 
Characteristics \\
\cline { 2 - 4 }
\end{tabular}} & Employment & $\mathbf{6 4 6 7}$ & $\mathbf{5 0 7 6}$ & $\mathbf{1 3 9 0}$ \\
\hline Working & $\mathbf{( \% )}$ & $\mathbf{( \% )}$ & $\mathbf{( \% )}$ \\
\hline Retired & 44 & 46 & 35 \\
\hline Housewife & 1 & 1 & 2 \\
\hline Student & 39 & 39 & 43 \\
\hline Unemployed & 7 & 6 & 10 \\
\hline Age Group & 9 & 9 & 10 \\
\hline $18-24$ & $\%$ & $\%$ & $\%$ \\
\hline $25-34$ & 26 & 25 & 29 \\
\hline $35-44$ & 27 & 28 & 27 \\
\hline $45-54$ & 23 & 23 & 21 \\
\hline $65+$ & 14 & 14 & 13 \\
\hline
\end{tabular}

\section{Main Occupation}

\begin{tabular}{|l|c|c|c|}
\hline $\begin{array}{l}\text { Main Occupation } \\
\text { Base: Currently working and retired } \\
\text { respondents }\end{array}$ & All & Rural & Urban \\
\hline & $\mathbf{2 8 8 3}$ & $\mathbf{2 3 7 2}$ & $\mathbf{5 1 1}$ \\
\hline Farmer (own land / tenant farmer) & 34 & $\mathbf{( \% )}$ & $\mathbf{( \% )}$ \\
\hline Farm labourer (other's land) & 13 & 14 & 9 \\
\hline Labourer, domestic, or unskilled worker & 6 & 6 & 4 \\
\hline Informal sales/ business & 10 & 9 & 16 \\
\hline Skilled worker/artisan & 10 & 9 & 17 \\
\hline Government office - clerical worker & 3 & 2 & 6 \\
\hline Private office - clerical worker & 1 & 1 & 3 \\
\hline Government office - executive/manager & 1 & $*$ & 1 \\
\hline Private office - executive/manager & $*$ & $*$ & 1 \\
\hline Self-employed professional & 9 & 8 & 14 \\
\hline Small business owner & 5 & 5 & 6 \\
\hline School teacher & 5 & 5 & 9 \\
\hline University teacher & $*$ & $*$ & $*$ \\
\hline Military/Police & 1 & 1 & 3 \\
\hline Don't know & 2 & 1 & 3 \\
\hline
\end{tabular}




\section{Farming Land}

\begin{tabular}{|l|c|c|c|}
\hline Farming Land & All & Rural & Urban \\
\hline Base: Farmers who own land or tenant farmers & $\mathbf{9 7 9}$ & $\mathbf{9 3 5}$ & 44 \\
\hline & $\mathbf{( \% )}$ & $\mathbf{( \% )}$ & $\mathbf{( \% )}$ \\
\hline Less than 1 Jerib & 8 & 8 & 7 \\
\hline 1 - 2 Jerib & 21 & 21 & 26 \\
\hline 2.1 - 3 Jerib & 29 & 29 & 19 \\
\hline More than 3 Jerib & 39 & 39 & 40 \\
\hline Don't know & 3 & 3 & 7 \\
\hline
\end{tabular}

* Jerib: One Jerib is equal to one fifth of a hectare.

\section{Average Monthly Household Income}

\begin{tabular}{|l|c|c|c|}
\hline Income & All & Rural & Urban \\
\hline & $\mathbf{6 4 6 7}$ & $\mathbf{5 0 7 6}$ & $\mathbf{1 3 9 0}$ \\
\hline Less than 2,000 Afs & $\mathbf{( \% )}$ & $\mathbf{( \% )}$ & $\mathbf{( \% )}$ \\
\hline $2,001-3,000$ Afs & 13 & 15 & 7 \\
\hline $3,001-5,000$ Afs & 20 & 21 & 14 \\
\hline $5,001-10,000$ Afs & 20 & 21 & 17 \\
\hline $10,001-15,000$ Afs & 27 & 25 & 35 \\
\hline $15,001-20,000$ Afs & 10 & 10 & 13 \\
\hline $20,001-25,000$ Afs & 4 & 4 & 7 \\
\hline $25,001-40,000$ Afs & 2 & 1 & 3 \\
\hline More then 40,000 Afs & 1 & 1 & 2 \\
\hline Refused & 2 & 2 & 2 \\
\hline Don't know & $*$ & $*$ & 0 \\
\hline
\end{tabular}

\section{Marital Status}

\begin{tabular}{|l|c|c|c|}
\hline Marital Status & All & Rural & Urban \\
\hline & $\mathbf{6 4 6 7}$ & $\mathbf{5 0 7 6}$ & $\mathbf{1 3 9 0}$ \\
\hline Single & $(\%)$ & $(\%)$ & $(\%)$ \\
\hline Married & 19 & 18 & 25 \\
\hline Widower/ Widow & 78 & 80 & 73 \\
\hline
\end{tabular}


160 | Afghanistan in 2010

\section{Educational Status}

\begin{tabular}{|l|c|c|c|}
\hline \multirow{2}{*}{ Educational Status } & All & Rural & Urban \\
\hline & $\mathbf{6 4 6 7}$ & $\mathbf{5 0 7 6}$ & $\mathbf{1 3 9 0}$ \\
\hline Never went to school & $\mathbf{( \% )}$ & $\mathbf{( \% )}$ & $\mathbf{( \% )}$ \\
\hline Primary School, incomplete & 57 & 61 & 42 \\
\hline Primary School, complete & 9 & 9 & 8 \\
\hline Secondary education, incomplete & 6 & 6 & 4 \\
\hline Secondary education, complete & 5 & 5 & 6 \\
\hline High School & 4 & 4 & 5 \\
\hline University education or above & 16 & 13 & 26 \\
\hline
\end{tabular}




\section{Appendix 2: Methodology}

\section{Distribution of sampling points by region and urban/rural strata}

The survey was conducted among 6467 respondents in a single wave. Fieldwork for the survey was conducted by the Afghan Center for Socio-economic and Opinion Research (ACSOR-Surveys), Kabul, between June 18 and July 5, 2010 by a team of 634 trained interviewers (272 women and 362 men). The survey consisted of inperson interviews with a random, representative sample of 6467 Afghan citizens, 18 years of age and over and resident in Afghanistan.

The survey included both urban and rural respondents in all provinces of Afghanistan. The Sheharwali (municipal administration in Afghanistan) defines the urban population as those living within municipal boundaries. By default, the rural population comprises those who are living outside the municipal limits. Rural areas are defined neither in terms of population density nor remoteness.

The country is divided into 8 geographical regions covering all 34 provinces. The sample was distributed proportional to geographic and residential characteristics of the population in each province, covering all 34 provinces and 285 of the total 398 districts (including 34 provincial capitals). Within each province, districts were selected by first listing them by size of population and then applying a random selection method from this list.

The sample was distributed with sampling points of 8 respondents. For provinces with low population density, such as Samangan, Logar, Zabul, Urozgan, Nimroz, Panjshir and Nooristan, 5 interviews per sampling point were conducted, rather than 8 , to offer broader geographic distribution.

The margin of sampling error is calculated at a cumulative of $+/-4.4$ percent at 95 percent confidence interval. The stochastic error is $+/-2.4$ percent while the systemic error is $+/-2.0$ percent. The systemic error appears because of the areas not accessible for surveying this year. The systemic error percentage is based on the retrospective calculation of the contribution of the inaccessible areas in the data for 2008.

\section{Selection of sampling points and replacement of sampling Points}

The interviews were completed using multi-stage random sampling. Due to local cultural traditions, the sample was first divided into male and female sub-samples. Each region, province and further strata was allocated an equal number of male and 
female respondents per sampling points. Field researchers of the appropriate gender were allocated to conduct the interviews for each sub-sample. However, in 2010, in 2 southern provinces; Paktika and Urozgan, the deteriorated security situation restricted the freedom of movement, making it unsafe to employ female interviewers. This meant that no women were included in the sample in these provinces.

Moreover, in 2010, there were greater restrictions on the movement of survey researchers than in previous years. A number of districts in the country could not be surveyed because of inaccessibility due to logistical problems, natural disasters and security. Overall 213 of the 885 sampling points had to be replaced. The replacements were made by selecting other sampling points in the same province. The instability and frequent fighting in some provinces caused 138 of the sampling points across the country ( $65 \%$ of replacements, or $16 \%$ of all substitutions) to be adjusted or replaced to keep interviewers out of areas affected by active violence. This has increased from 2009 when 102 sampling points (12\%) had to be replaced for security reasons. The regions most severely affected by these restrictions are the South East (28 replacements), South West (24 replacements), North East (23 replacements) and East (21 replacements). There were 20 such replacements made in the North West, 12 in the West, and 10 in Central/ Kabul regions. In regions with significant numbers of sampling points had to be changed for security reasons individual provinces with the most changed included Kunarha (15 replacements) in the East, Baghlan (14 replacements) in the North East, and Zabul (10 replacements) in the South West. Nangarhar, Badghis and Urozgan were the only provinces where sampling points did not have to be replaced. 
Replacement of the sampling points and the reason for replacement is described in the following table.

\begin{tabular}{|c|c|c|c|c|}
\hline Province & SP & Projected District/Village & Replaced with & Reason \\
\hline \multirow[t]{7}{*}{ 1. Kabul } & 90 & Qalha Pirak. Village & Mirza Khil. Village & $\begin{array}{l}\text { No village found } \\
\text { in such name }\end{array}$ \\
\hline & 94 & Dowere. Village & Logari. Village & $\begin{array}{l}\text { No village found } \\
\text { in such name }\end{array}$ \\
\hline & 96 & Khak Shahedan. Village & Qul Nehal. Village & $\begin{array}{l}\text { No village found } \\
\text { in such name }\end{array}$ \\
\hline & 97 & Sayedan Gulestan. Village & $\begin{array}{l}\text { Erfan Pushta Bala. Vil- } \\
\text { lage }\end{array}$ & $\begin{array}{l}\text { No village found } \\
\text { in such name }\end{array}$ \\
\hline & 103 & Malakh Zar. Village & Salah Khil. Village & $\begin{array}{l}\text { No village found } \\
\text { in such name }\end{array}$ \\
\hline & 104 & Mamo Khil. Village & Sulaiman. Village & $\begin{array}{l}\text { No village found } \\
\text { in such name }\end{array}$ \\
\hline & 105 & Tajikan Khwaja Ha. Village & $\begin{array}{l}\text { Qaria Bagh Zaghan. } \\
\text { Village }\end{array}$ & $\begin{array}{l}\text { No village found } \\
\text { in such name }\end{array}$ \\
\hline \multirow[t]{2}{*}{ 2. Kapisa } & 117 & Tagab. District & Alasay. District & $\begin{array}{l}\text { The district is } \\
\text { under control of } \\
\text { Taliban }\end{array}$ \\
\hline & 118 & Tagab. District & Alasay. District & $\begin{array}{l}\text { The district is } \\
\text { under control of } \\
\text { Taliban }\end{array}$ \\
\hline \multirow[t]{4}{*}{ 3. Parwan } & 124 & $\begin{array}{l}\text { Nahhia Awal Parcha } 3 \\
\text { Shahri. District }\end{array}$ & $\begin{array}{l}\text { Parcha Shashum. Dis- } \\
\text { trict }\end{array}$ & $\begin{array}{l}\text { The district is } \\
\text { under control of } \\
\text { Taliban }\end{array}$ \\
\hline & 126 & Pichapich. District & Daraz Gerd. District & $\begin{array}{l}\text { The district is } \\
\text { under control of } \\
\text { Taliban }\end{array}$ \\
\hline & 127 & Kangara. District & Darazed. District & $\begin{array}{l}\text { The district is } \\
\text { under control of } \\
\text { Taliban }\end{array}$ \\
\hline & 130 & Chinkay Alia. District & $\begin{array}{l}\text { Dehan Changak. Dis- } \\
\text { trict }\end{array}$ & $\begin{array}{l}\text { No village found } \\
\text { in such name }\end{array}$ \\
\hline 33. Panjshir & 150 & Piawasht Balaq. Village & Pakhyar. Village & $\begin{array}{l}\text { No village found } \\
\text { in such name }\end{array}$ \\
\hline \multirow[t]{4}{*}{ 12. Kunarha } & 196 & Nari. District & Dangam. District & $\begin{array}{l}\text { The district is } \\
\text { under control of } \\
\text { Taliban }\end{array}$ \\
\hline & 204 & Darai Pich. District & Wata por. District & $\begin{array}{l}\text { The district is } \\
\text { under control of } \\
\text { Taliban }\end{array}$ \\
\hline & 205 & Darai Pich. District & Wata por. District & $\begin{array}{l}\text { The district is } \\
\text { under control of } \\
\text { Taliban }\end{array}$ \\
\hline & 196 & Bar Shor Kamar. Village & $\begin{array}{l}\text { Ghur Bijo Kami. Vil- } \\
\text { lage }\end{array}$ & $\begin{array}{l}\text { The district is } \\
\text { under control of } \\
\text { Taliban }\end{array}$ \\
\hline
\end{tabular}




\begin{tabular}{|c|c|c|c|c|}
\hline & 198 & Toot Oba. Village & Shina Ali Kalai. Village & $\begin{array}{l}\text { The district is } \\
\text { under control of } \\
\text { Taliban }\end{array}$ \\
\hline & 199 & Ganjgal. Village & Tango. Village & $\begin{array}{l}\text { The district is } \\
\text { under control of } \\
\text { Taliban }\end{array}$ \\
\hline & 200 & Gach Gal. Village & Qalha Gani. Village & $\begin{array}{l}\text { The district is } \\
\text { under control of } \\
\text { Taliban }\end{array}$ \\
\hline & 201 & Mora. Village & Esari Dag. Village & $\begin{array}{l}\text { The district is } \\
\text { under control of } \\
\text { Taliban }\end{array}$ \\
\hline & 202 & Doli Khaye. Village & Dari Khar. Village & $\begin{array}{l}\text { The district is } \\
\text { under control of } \\
\text { Taliban }\end{array}$ \\
\hline & 204 & Darwazgi. Village & $\begin{array}{l}\text { Shah Mir Kott Kalai. } \\
\text { Village }\end{array}$ & $\begin{array}{l}\text { The district is } \\
\text { under control of } \\
\text { Taliban }\end{array}$ \\
\hline & 205 & Dahuz Chardangi. Village & $\begin{array}{l}\text { Mulaiano Ghundi. Vil- } \\
\text { lage }\end{array}$ & $\begin{array}{l}\text { The district is } \\
\text { under control of } \\
\text { Taliban }\end{array}$ \\
\hline & 206 & Sir Gul. Village & Dar Samona. Village & $\begin{array}{l}\text { The district is } \\
\text { under control of } \\
\text { Taliban }\end{array}$ \\
\hline & 207 & $\begin{array}{l}\text { Anrar Luchak Naw. Vil- } \\
\text { lage }\end{array}$ & Kandal. Village & $\begin{array}{l}\text { The district is } \\
\text { under control of } \\
\text { Taliban }\end{array}$ \\
\hline & 208 & Roshan Kandak. Village & Bar Noor Gal. Village & $\begin{array}{l}\text { The district is } \\
\text { under control of } \\
\text { Taliban }\end{array}$ \\
\hline & 209 & Arat. Village & Patan. Village & $\begin{array}{l}\text { The village is } \\
\text { under control of } \\
\text { Taliban }\end{array}$ \\
\hline 11. Laghman & 217 & Bar Kashmon. Village & Usain Abad. Village & $\begin{array}{l}\text { The village is } \\
\text { under control of } \\
\text { Taliban }\end{array}$ \\
\hline & 219 & Hazar Banda. Village & Aji Guldad. Village & $\begin{array}{l}\text { The village is } \\
\text { under control of } \\
\text { Taliban }\end{array}$ \\
\hline & 221 & Abilam. Village & Rajaye. Village & $\begin{array}{l}\text { The village is } \\
\text { under control of } \\
\text { Taliban }\end{array}$ \\
\hline 13. Noorestan & 921 & Hugur. Village & $\begin{array}{l}\text { Kamdish Koz Kalai. } \\
\text { Village }\end{array}$ & $\begin{array}{l}\text { The village is } \\
\text { under control of } \\
\text { Taliban }\end{array}$ \\
\hline & 927 & Machum Kandwa. Village & Khando. Village & $\begin{array}{l}\text { The village is } \\
\text { under control of } \\
\text { Taliban }\end{array}$ \\
\hline
\end{tabular}




\begin{tabular}{|c|c|c|c|c|}
\hline & 928 & Bosidar. Village & Anis. Village & $\begin{array}{l}\text { The village is } \\
\text { under control of } \\
\text { Taliban }\end{array}$ \\
\hline \multirow[t]{4}{*}{ 4. Wardak } & 245 & Chake Wardak. District & Jalrez. District & $\begin{array}{l}\text { The district is } \\
\text { under control of } \\
\text { Taliban }\end{array}$ \\
\hline & 246 & Chake Wardak. District & Jalrez. District & $\begin{array}{l}\text { The district is } \\
\text { under control of } \\
\text { Taliban }\end{array}$ \\
\hline & 246 & $\begin{array}{l}\text { Dehan Armon Sanglakh. } \\
\text { Village }\end{array}$ & Bar Kharoti. Village & $\begin{array}{l}\text { No transporta- } \\
\text { tion way for ve- } \\
\text { hicles }\end{array}$ \\
\hline & 248 & Qalha Ziarat & Deh Hayat. Village & $\begin{array}{l}\text { Security Prob- } \\
\text { lems }\end{array}$ \\
\hline \multirow[t]{3}{*}{ 5. Logar } & 253 & Azra. District & Khushi. District & $\begin{array}{l}\text { The district is } \\
\text { under control of } \\
\text { Taliban }\end{array}$ \\
\hline & 254 & Azra. Dsitrict & Charkh. District & $\begin{array}{l}\text { The district is } \\
\text { under control of } \\
\text { Taliban }\end{array}$ \\
\hline & 267 & Sar Pul. Village & Kadi. Village & $\begin{array}{l}\text { No village found } \\
\text { in such name }\end{array}$ \\
\hline \multirow[t]{9}{*}{ 6. Ghazni } & 270 & Abband. District & Waghaz. District & $\begin{array}{l}\text { The district is } \\
\text { under control of } \\
\text { Taliban }\end{array}$ \\
\hline & 271 & Abband. District & Waghaz. District & $\begin{array}{l}\text { The district is } \\
\text { under control of } \\
\text { Taliban }\end{array}$ \\
\hline & 272 & Rashidan. District & Deh Yak. District & $\begin{array}{l}\text { The district is } \\
\text { under control of } \\
\text { Taliban }\end{array}$ \\
\hline & 273 & Rashidan. District & Deh Yak. District & $\begin{array}{l}\text { The district is } \\
\text { under control of } \\
\text { Taliban }\end{array}$ \\
\hline & 284 & Dehan Gardan. Village & Kuhna Deh. Village & $\begin{array}{l}\text { The district is } \\
\text { under control of } \\
\text { Taliban }\end{array}$ \\
\hline & 285 & Sadat Sar Takhta. Village & Laghar Joy. Village & $\begin{array}{l}\text { The district is } \\
\text { under control of } \\
\text { Taliban }\end{array}$ \\
\hline & 286 & Andar. District & Khwaja Omari. District & $\begin{array}{l}\text { The district is } \\
\text { under control of } \\
\text { Taliban }\end{array}$ \\
\hline & 287 & Andar. District & Khwaja Omari. District & $\begin{array}{l}\text { The district is } \\
\text { under control of } \\
\text { Taliban }\end{array}$ \\
\hline & 288 & Andar. District & Khwaja Omari. District & $\begin{array}{l}\text { The district is } \\
\text { under control of } \\
\text { Taliban }\end{array}$ \\
\hline
\end{tabular}




\begin{tabular}{|c|c|c|c|c|}
\hline & 289 & Andar. District & Khwaja Omari. District & $\begin{array}{l}\text { The district is } \\
\text { under control of } \\
\text { Taliban }\end{array}$ \\
\hline & 304 & Giro. District & Ghazni - town. District & $\begin{array}{l}\text { The district is } \\
\text { under control of } \\
\text { Taliban }\end{array}$ \\
\hline \multirow[t]{7}{*}{ 7. Paktia } & 307 & Janikheli. District & $\begin{array}{l}\text { Laja Ahmad Khel. Dis- } \\
\text { trict }\end{array}$ & $\begin{array}{l}\text { The district is } \\
\text { under control of } \\
\text { Taliban }\end{array}$ \\
\hline & 309 & Shwak. District & Wuza Jadran. District & $\begin{array}{l}\text { The district is } \\
\text { under control of } \\
\text { Taliban }\end{array}$ \\
\hline & 310 & Zurmat. District & Ahmad Aba. District & $\begin{array}{l}\text { The district is } \\
\text { under control of } \\
\text { Taliban }\end{array}$ \\
\hline & 311 & Zurmat. District & Ahmad Aba. District & $\begin{array}{l}\text { The district is } \\
\text { under control of } \\
\text { Taliban }\end{array}$ \\
\hline & 312 & Zurmat. District & Ahmad Aba. District & $\begin{array}{l}\text { The district is } \\
\text { under control of } \\
\text { Taliban }\end{array}$ \\
\hline & 313 & Zurmat. District & Ahmad Aba. District & $\begin{array}{l}\text { The district is } \\
\text { under control of } \\
\text { Taliban }\end{array}$ \\
\hline & 321 & Chamkani. District & Dand Patan. District & $\begin{array}{l}\text { The district is } \\
\text { under control of } \\
\text { Taliban }\end{array}$ \\
\hline \multirow[t]{6}{*}{ 8. Paktika } & 322 & Waza Khwah. District & $\begin{array}{l}\text { Dila Wa Khushamand. } \\
\text { District }\end{array}$ & $\begin{array}{l}\text { The district is } \\
\text { under control of } \\
\text { Taliban }\end{array}$ \\
\hline & 323 & Waza Khwah. District & Jani Khel. District & $\begin{array}{l}\text { The district is } \\
\text { under control of } \\
\text { Taliban }\end{array}$ \\
\hline & 325 & Surubi. District & Omna. District & $\begin{array}{l}\text { The district is } \\
\text { under control of } \\
\text { Taliban }\end{array}$ \\
\hline & 327 & Urgoon. District & Nika. District & $\begin{array}{l}\text { The district is } \\
\text { under control of } \\
\text { Taliban }\end{array}$ \\
\hline & 330 & Branal. District & Yousof Khel. District & $\begin{array}{l}\text { The district is } \\
\text { under control of } \\
\text { Taliban }\end{array}$ \\
\hline & 333 & Zarghunshahr. District & Yahya Khel. District & $\begin{array}{l}\text { The district is } \\
\text { under control of } \\
\text { Taliban }\end{array}$ \\
\hline 9. Khost & 336 & Spera. District & Tani. District & $\begin{array}{l}\text { The district is } \\
\text { under control of } \\
\text { Taliban }\end{array}$ \\
\hline
\end{tabular}




\begin{tabular}{|c|c|c|c|c|}
\hline & 337 & Spera. District & Tani. District & $\begin{array}{l}\text { The district is } \\
\text { under control of } \\
\text { Taliban }\end{array}$ \\
\hline & 344 & Sabari. District & Jaji Maidan. District & $\begin{array}{l}\text { The district is } \\
\text { under control of } \\
\text { Taliban }\end{array}$ \\
\hline & 345 & Sabari. District & Jaji Maidan. District & $\begin{array}{l}\text { The district is } \\
\text { under control of } \\
\text { Taliban }\end{array}$ \\
\hline \multirow[t]{4}{*}{ 27. Helmand } & 372 & Bughran. District & Musa Qala. District & $\begin{array}{l}\text { The district is } \\
\text { under control of } \\
\text { Taliban }\end{array}$ \\
\hline & 373 & Bughran. District & Musa Qala. District & $\begin{array}{l}\text { The district is } \\
\text { under control of } \\
\text { Taliban }\end{array}$ \\
\hline & 374 & Bughran. District & Sangin. District & $\begin{array}{l}\text { The district is } \\
\text { under control of } \\
\text { Taliban }\end{array}$ \\
\hline & 375 & Bughran. District & Sangin. District & $\begin{array}{l}\text { The district is } \\
\text { under control of } \\
\text { Taliban }\end{array}$ \\
\hline \multirow[t]{2}{*}{ 28. Kandahar } & 393 & Myanasheen. District & Shah Wali Kot. District & $\begin{array}{l}\text { The district is } \\
\text { under control of } \\
\text { Taliban }\end{array}$ \\
\hline & 394 & Myanasheen. District & Shah Wali Kot. District & $\begin{array}{l}\text { The district is } \\
\text { under control of } \\
\text { Taliban }\end{array}$ \\
\hline \multirow[t]{7}{*}{ 29. Zabul } & 417 & Meezan. District & Shikai. District & $\begin{array}{l}\text { Security Prob- } \\
\text { lems }\end{array}$ \\
\hline & 420 & Shah Joi. District & $\begin{array}{l}\text { Tarnak Wa Jaldak. Dis- } \\
\text { trict }\end{array}$ & $\begin{array}{l}\text { The district is } \\
\text { under control of } \\
\text { Taliban }\end{array}$ \\
\hline & 421 & Shah Joi. District & $\begin{array}{l}\text { Tarnak Wa Jaldak. Dis- } \\
\text { trict }\end{array}$ & $\begin{array}{l}\text { The district is } \\
\text { under control of } \\
\text { Taliban }\end{array}$ \\
\hline & 423 & Daichopan. District & Kakar. District & $\begin{array}{l}\text { The district is } \\
\text { under control of } \\
\text { Taliban }\end{array}$ \\
\hline & 425 & Arghandab. District & Naw Bahar. District & $\begin{array}{l}\text { The district is } \\
\text { under control of } \\
\text { Taliban }\end{array}$ \\
\hline & 427 & Shemel Zayi. District & Atghar. District & $\begin{array}{l}\text { The district is } \\
\text { under control of } \\
\text { Taliban }\end{array}$ \\
\hline & 417 & Pataw. Village & Mandin Khil. Village & $\begin{array}{l}\text { The village is } \\
\text { under control of } \\
\text { Taliban }\end{array}$ \\
\hline
\end{tabular}




\begin{tabular}{|c|c|c|c|c|}
\hline & 418 & Muqam. Village & Bazergan. Village & $\begin{array}{l}\text { The village is } \\
\text { under control of } \\
\text { Taliban }\end{array}$ \\
\hline & 421 & Sra Shah. Village & Nawa Jaldak. Village & $\begin{array}{l}\text { The village is } \\
\text { under control of } \\
\text { Taliban }\end{array}$ \\
\hline & 932 & Baghto. Village & $\begin{array}{l}\text { Abdul Rahof Qalha. } \\
\text { Village }\end{array}$ & $\begin{array}{l}\text { The village is } \\
\text { under control of } \\
\text { Taliban }\end{array}$ \\
\hline \multirow[t]{8}{*}{ 26. Nimroz } & 446 & $\begin{array}{l}\text { Alili Amanullah Khan. } \\
\text { Village }\end{array}$ & $\begin{array}{l}\text { Mohamad Azim. Vil- } \\
\text { lage }\end{array}$ & $\begin{array}{l}\text { The village is } \\
\text { under control of } \\
\text { Taliban }\end{array}$ \\
\hline & 450 & Khashroad. District & Char Burjak. District & $\begin{array}{l}\text { The district is } \\
\text { under control of } \\
\text { Taliban }\end{array}$ \\
\hline & 451 & Khashroad. District & Char Burjak. District & $\begin{array}{l}\text { The district is } \\
\text { under control of } \\
\text { Taliban }\end{array}$ \\
\hline & 452 & $\begin{array}{l}\text { Alqayum Mohammad } \\
\text { Rafeq. Village }\end{array}$ & Siah Khan. Village & $\begin{array}{l}\text { The village is } \\
\text { under control of } \\
\text { Taliban }\end{array}$ \\
\hline & 942 & $\begin{array}{l}\text { Ghulam Muhidun. Vil- } \\
\text { lage }\end{array}$ & $\begin{array}{l}\text { Aji Abdul Rahman. Vil- } \\
\text { lage }\end{array}$ & $\begin{array}{l}\text { The village is } \\
\text { under control of } \\
\text { Taliban }\end{array}$ \\
\hline & 943 & Shora Aye. Village & Kherot. Village & $\begin{array}{l}\text { The village is } \\
\text { under control of } \\
\text { Taliban }\end{array}$ \\
\hline & 943 & Khashroad. District & Kang. District & $\begin{array}{l}\text { The district is } \\
\text { under control of } \\
\text { Taliban }\end{array}$ \\
\hline & 944 & Khashroad. District & Kang. District & $\begin{array}{l}\text { The district is } \\
\text { under control of } \\
\text { Taliban }\end{array}$ \\
\hline \multirow[t]{4}{*}{ 24. Herat } & 478 & Mir Abad. Village & Nawen. Village & $\begin{array}{l}\text { The village is } \\
\text { under control } \\
\text { of Taliban }\end{array}$ \\
\hline & 499 & Khair Abad. Village & Gul Bibi. Village & $\begin{array}{l}\text { The village is } \\
\text { under control } \\
\text { of Taliban }\end{array}$ \\
\hline & 500 & Deh Shakar. Village & $\begin{array}{l}\text { Mahajer Abad. Vil- } \\
\text { lage }\end{array}$ & $\begin{array}{l}\text { The village is } \\
\text { under control } \\
\text { of Taliban }\end{array}$ \\
\hline & 501 & Joy Naw. Village & $\begin{array}{l}\text { Rubat Sidiq Alia. Vil- } \\
\text { lage }\end{array}$ & $\begin{array}{l}\text { Due to flood } \\
\text { the way was } \\
\text { blocked }\end{array}$ \\
\hline
\end{tabular}




\begin{tabular}{|c|c|c|c|c|}
\hline \multirow[t]{11}{*}{ 25. Farah } & 508 & Tekrar. Village & Nahia 6. Village & $\begin{array}{l}\text { No village } \\
\text { found in such } \\
\text { name }\end{array}$ \\
\hline & 509 & Lash-i-Jaween. District & Anar Dara. District & $\begin{array}{l}\text { The district is } \\
\text { under control } \\
\text { of Taliban }\end{array}$ \\
\hline & 511 & Kariz Naghak. Village & $\begin{array}{l}\text { Awzak Abdul Qader. } \\
\text { Village }\end{array}$ & $\begin{array}{l}\text { The village is } \\
\text { under control } \\
\text { of Taliban }\end{array}$ \\
\hline & 512 & $\begin{array}{l}\text { Khwaja Mohammad } \\
\text { Hasham. Village }\end{array}$ & Bawdeh. Village & $\begin{array}{l}\text { No transpor- } \\
\text { tation way for } \\
\text { vehicles }\end{array}$ \\
\hline & 513 & $\begin{array}{l}\text { Kariz Allah Dad. Vil- } \\
\text { lage }\end{array}$ & Nahia Awal. Village & $\begin{array}{l}\text { The district is } \\
\text { under control } \\
\text { of Taliban }\end{array}$ \\
\hline & 514 & $\begin{array}{l}\text { Kariz Lal Mohammad. } \\
\text { Village }\end{array}$ & $\begin{array}{l}\text { Qalha Zaman Khan. } \\
\text { Village }\end{array}$ & $\begin{array}{l}\text { The district is } \\
\text { under control } \\
\text { of Taliban }\end{array}$ \\
\hline & 515 & Artughnak. Village & $\begin{array}{l}\text { Ziarat Alokozai. Vil- } \\
\text { lage }\end{array}$ & $\begin{array}{l}\text { The district is } \\
\text { under control } \\
\text { of Taliban }\end{array}$ \\
\hline & 517 & Pur Chaman. District & Gulistan. District & $\begin{array}{l}\text { The district is } \\
\text { under control } \\
\text { of Taliban }\end{array}$ \\
\hline & 520 & $\begin{array}{l}\text { Gul Ashtar Bala. Vil- } \\
\text { lage }\end{array}$ & Naw Bahar. Village & $\begin{array}{l}\text { The district is } \\
\text { under control } \\
\text { of Taliban }\end{array}$ \\
\hline & 521 & Bakwa. District & Qala -i- Kah. District & $\begin{array}{l}\text { The district is } \\
\text { under control } \\
\text { of Taliban }\end{array}$ \\
\hline & 522 & Bakwa. District & Qala -i- Kah. District & $\begin{array}{l}\text { The district is } \\
\text { under control } \\
\text { of Taliban }\end{array}$ \\
\hline \multirow[t]{3}{*}{$\begin{array}{l}\text { 14. Badakh- } \\
\text { shan }\end{array}$} & 532 & $\begin{array}{l}\text { Naw Abad Doghlata. Vil- } \\
\text { lage }\end{array}$ & $\begin{array}{l}\text { Khair Abad Qarlaq. } \\
\text { Village }\end{array}$ & $\begin{array}{l}\text { No transporta- } \\
\text { tion way for ve- } \\
\text { hicles }\end{array}$ \\
\hline & 533 & Naw Abad. Village & Eshan Abad. Village & $\begin{array}{l}\text { No transporta- } \\
\text { tion way for ve- } \\
\text { hicles }\end{array}$ \\
\hline & 534 & Yojikil. Village & Nalan. Village & $\begin{array}{l}\text { No transporta- } \\
\text { tion way for ve- } \\
\text { hicles }\end{array}$ \\
\hline
\end{tabular}




\begin{tabular}{|c|c|c|c|c|}
\hline & 536 & Payan Mor. Village & Rubat Gulak. Village & $\begin{array}{l}\text { Due to flood the } \\
\text { way was blocked }\end{array}$ \\
\hline & 537 & Gardanak. Village & Dasht Farang. Village & $\begin{array}{l}\text { Due to flood the } \\
\text { way was blocked }\end{array}$ \\
\hline & 542 & Kahm Bil. Village & Asan Biki. Village & $\begin{array}{l}\text { No transporta- } \\
\text { tion way for ve- } \\
\text { hicles }\end{array}$ \\
\hline & 543 & Dargak. Village & Dasht Shuhada. Village & $\begin{array}{l}\text { No transporta- } \\
\text { tion way for ve- } \\
\text { hicles }\end{array}$ \\
\hline & 551 & Khambio Bala. Village & Zaran. Village & $\begin{array}{l}\text { No transporta- } \\
\text { tion way for ve- } \\
\text { hicles }\end{array}$ \\
\hline & 548 & Shiki. District & Baharak. District & $\begin{array}{l}\text { No transporta- } \\
\text { tion way for ve- } \\
\text { hicles }\end{array}$ \\
\hline & 549 & Shiki. District & Baharak. District & $\begin{array}{l}\text { No transporta- } \\
\text { tion way for ve- } \\
\text { hicles }\end{array}$ \\
\hline & 550 & Darwaz-i-Bala. District & $\begin{array}{l}\text { Arghanj Khwah. Dis- } \\
\text { trict }\end{array}$ & $\begin{array}{l}\text { No transporta- } \\
\text { tion way for ve- } \\
\text { hicles }\end{array}$ \\
\hline & 551 & Darwaz-i-Bala. District & $\begin{array}{l}\text { Arghanj Khwah. Dis- } \\
\text { trict }\end{array}$ & $\begin{array}{l}\text { No transporta- } \\
\text { tion way for ve- } \\
\text { hicles }\end{array}$ \\
\hline 15. Takhar & 556 & $\begin{array}{l}\text { Changraq Chashma } \\
\text { Naqelen Taleqani. Village }\end{array}$ & Gul Bahar. Village & $\begin{array}{l}\text { Security Prob- } \\
\text { lems }\end{array}$ \\
\hline & 557 & Qarlari. Village & Lala Guzar. Village & $\begin{array}{l}\text { The district is } \\
\text { under control of } \\
\text { Taliban }\end{array}$ \\
\hline & 558 & Hal Pitaw. Village & $\begin{array}{l}\text { Bolak Warta Buz. Vil- } \\
\text { lage }\end{array}$ & $\begin{array}{l}\text { No transporta- } \\
\text { tion way for ve- } \\
\text { hicles }\end{array}$ \\
\hline & 560 & Munara. Village & $\begin{array}{l}\text { Naw Abad Hazara. Vil- } \\
\text { lage }\end{array}$ & $\begin{array}{l}\text { No transporta- } \\
\text { tion way for ve- } \\
\text { hicles }\end{array}$ \\
\hline & 566 & Jura Bay. Village & Qazal Qalha. Village & $\begin{array}{l}\text { No transporta- } \\
\text { tion way for ve- } \\
\text { hicles }\end{array}$ \\
\hline & 567 & Zarif Bay. Village & Shah Asan. Village & $\begin{array}{l}\text { People do not } \\
\text { live there }\end{array}$ \\
\hline & 569 & Zard Kamar. Village & Jo Kado. Village & $\begin{array}{l}\text { The district is } \\
\text { under control } \\
\text { of Taliban }\end{array}$ \\
\hline
\end{tabular}




\begin{tabular}{|c|c|c|c|c|}
\hline & 572 & Hudi. Village & $\begin{array}{l}\text { Masjed Hazrat Bibi Ay- } \\
\text { sha. Village }\end{array}$ & $\begin{array}{l}\text { Due to flood } \\
\text { the way was } \\
\text { blocked }\end{array}$ \\
\hline & 573 & Dehana Qeshlaq. Village & $\begin{array}{l}\text { Masjed Hazrat Sulai- } \\
\text { man. Village }\end{array}$ & $\begin{array}{l}\text { Due to flood } \\
\text { the way was } \\
\text { blocked }\end{array}$ \\
\hline \multirow[t]{12}{*}{ 16. Baghlan } & 595 & $\begin{array}{l}\text { Baghlan-i-Jadeed - rural. } \\
\text { District }\end{array}$ & Burkah. District & $\begin{array}{l}\text { The district is } \\
\text { under control } \\
\text { of Taliban }\end{array}$ \\
\hline & 596 & $\begin{array}{l}\text { Baghlan-i-Jadeed - rural. } \\
\text { District }\end{array}$ & Burkah. District & $\begin{array}{l}\text { The district is } \\
\text { under control } \\
\text { of Taliban }\end{array}$ \\
\hline & 597 & $\begin{array}{l}\text { Baghlan-i-Jadeed - rural. } \\
\text { District }\end{array}$ & Burkah. District & $\begin{array}{l}\text { The village is } \\
\text { under control } \\
\text { of Taliban }\end{array}$ \\
\hline & 598 & $\begin{array}{l}\text { Baghlan-i-Jadeed - rural. } \\
\text { District }\end{array}$ & Khejan. District & $\begin{array}{l}\text { The district is } \\
\text { under control } \\
\text { of Taliban }\end{array}$ \\
\hline & 599 & $\begin{array}{l}\text { Baghlan-i-Jadeed - rural. } \\
\text { District }\end{array}$ & Khejan. District & $\begin{array}{l}\text { The district is } \\
\text { under control } \\
\text { of Taliban }\end{array}$ \\
\hline & 600 & $\begin{array}{l}\text { Baghlan-i-Jadeed - rural. } \\
\text { District }\end{array}$ & Dooshi. District & $\begin{array}{l}\text { The district is } \\
\text { under control } \\
\text { of Taliban }\end{array}$ \\
\hline & 587 & Anarak. Village & Kolola Sang. Village & $\begin{array}{l}\text { The village is } \\
\text { under control } \\
\text { of Taliban }\end{array}$ \\
\hline & 589 & Sar Pito. Village & Qalha. Village & $\begin{array}{l}\text { The village is } \\
\text { under control } \\
\text { of Taliban }\end{array}$ \\
\hline & 590 & Aspej Payeen. Village & Aita. Village & $\begin{array}{l}\text { The village is } \\
\text { under control } \\
\text { of Taliban }\end{array}$ \\
\hline & 594 & Chashma Shir. Village & Naw Abad. Village & $\begin{array}{l}\text { The village is } \\
\text { under control } \\
\text { of Taliban }\end{array}$ \\
\hline & 596 & Pish Kam. Village & Kal Ha. Village & $\begin{array}{l}\text { No village } \\
\text { found in such } \\
\text { name }\end{array}$ \\
\hline & 597 & Shor Qadoq. Village & $\begin{array}{l}\text { Naw Abad Chapa. Vil- } \\
\text { lage }\end{array}$ & $\begin{array}{l}\text { No village } \\
\text { found in such } \\
\text { name }\end{array}$ \\
\hline
\end{tabular}




\begin{tabular}{|c|c|c|c|c|}
\hline & 600 & Daka Ali Khil. Village & Ahangar Ha. Village & $\begin{array}{l}\text { No village } \\
\text { found in such } \\
\text { name }\end{array}$ \\
\hline & 601 & Marakez Daka. Village & $\begin{array}{l}\text { Chehl Ghuri Payen. } \\
\text { Village }\end{array}$ & $\begin{array}{l}\text { No village } \\
\text { found in such } \\
\text { name }\end{array}$ \\
\hline & 602 & Dara Kanda. Village & Chehl Ghuri. Village & $\begin{array}{l}\text { The village is } \\
\text { under control } \\
\text { of Taliban }\end{array}$ \\
\hline & 603 & $\begin{array}{l}\text { Quzi Babay Zangi. Vil- } \\
\text { lage }\end{array}$ & Shahr Naw. Village & $\begin{array}{l}\text { The village is } \\
\text { under control } \\
\text { of Taliban }\end{array}$ \\
\hline & 604 & Rahman. Village & Qasab Ha. Village & $\begin{array}{l}\text { No village } \\
\text { found in such } \\
\text { name }\end{array}$ \\
\hline & 607 & Maidan. Village & Khair Abad. Village & $\begin{array}{l}\text { The district is } \\
\text { under control } \\
\text { of Taliban }\end{array}$ \\
\hline & 608 & Chub Dara. Village & $\begin{array}{l}\text { Chashma Jangan. Vil- } \\
\text { lage }\end{array}$ & $\begin{array}{l}\text { The district is } \\
\text { under control } \\
\text { of Taliban }\end{array}$ \\
\hline 17. Kunduz & 616 & Luqman. Village & Laqi Alia. Village & $\begin{array}{l}\text { No village } \\
\text { found in such } \\
\text { name }\end{array}$ \\
\hline & 621 & Kharoti. Village & Qaria Qasab. Village & $\begin{array}{l}\text { The village is } \\
\text { under control } \\
\text { of Taliban }\end{array}$ \\
\hline & 622 & Tubra Kash. Village & Dost Ali. Village & $\begin{array}{l}\text { The village is } \\
\text { under control } \\
\text { of Taliban }\end{array}$ \\
\hline & 630 & $\begin{array}{l}\text { Bish Kapa Arabia. Vil- } \\
\text { lage }\end{array}$ & Tagan Tapa. Village & $\begin{array}{l}\text { The village is } \\
\text { under control } \\
\text { of Taliban }\end{array}$ \\
\hline & 633 & $\begin{array}{l}\text { Tarkan Jan Qataghan. } \\
\text { Village }\end{array}$ & Kocha Barod. Village & $\begin{array}{l}\text { The village is } \\
\text { under control } \\
\text { of Taliban }\end{array}$ \\
\hline & 634 & Manash. Village & $\begin{array}{l}\text { Mir Ghawsudin. Vil- } \\
\text { lage }\end{array}$ & $\begin{array}{l}\text { No village } \\
\text { found in such } \\
\text { name }\end{array}$ \\
\hline & 636 & Dasht-i-Archi. District & Qala-i- Zal. District & $\begin{array}{l}\text { The district is } \\
\text { under control } \\
\text { of Taliban }\end{array}$ \\
\hline & 637 & Dasht-i-Archi. District & Qala-i- Zal. District & $\begin{array}{l}\text { The district is } \\
\text { under control } \\
\text { of Taliban }\end{array}$ \\
\hline
\end{tabular}




\begin{tabular}{|c|c|c|c|c|}
\hline \multirow[t]{10}{*}{ 18. Balkh } & 652 & $\begin{array}{l}\text { Bodana Qalha Awal. Vil- } \\
\text { lage }\end{array}$ & Aranji. Village & $\begin{array}{l}\text { No village } \\
\text { found in such } \\
\text { name }\end{array}$ \\
\hline & 653 & Paikan Dara. Village & Noor Areq. Village & $\begin{array}{l}\text { No village } \\
\text { found in such } \\
\text { name }\end{array}$ \\
\hline & 660 & Qaland Safla. Village & Halqa Jar. Village & $\begin{array}{l}\text { The village is } \\
\text { under control } \\
\text { of Taliban }\end{array}$ \\
\hline & 661 & Jangali. Village & Sra Bangi. Village & $\begin{array}{l}\text { The village is } \\
\text { under control } \\
\text { of Taliban }\end{array}$ \\
\hline & 664 & Qafan. Village & Masjed Eshani. Village & $\begin{array}{l}\text { The village is } \\
\text { under control } \\
\text { of Taliban }\end{array}$ \\
\hline & 666 & $\begin{array}{l}\text { Kamsani Emam Saheb. } \\
\text { Village }\end{array}$ & $\begin{array}{l}\text { Naw Abad Bay Timor. } \\
\text { Village }\end{array}$ & $\begin{array}{l}\text { The village is } \\
\text { under control } \\
\text { of Taliban }\end{array}$ \\
\hline & 667 & Baloch Noshar. Village & Sarjar Pashtoni & $\begin{array}{l}\text { The village is } \\
\text { under control } \\
\text { of Taliban }\end{array}$ \\
\hline & 669 & $\begin{array}{l}\text { Nawared Taraki Emam } \\
\text { Saheb. Village }\end{array}$ & $\begin{array}{l}\text { Sayedan Yangi Qala } \\
\text { Masjed. Village }\end{array}$ & $\begin{array}{l}\text { The village is } \\
\text { under control } \\
\text { of Taliban }\end{array}$ \\
\hline & 674 & Chshma. Village & Naqelen. Village & $\begin{array}{l}\text { Due to flood } \\
\text { the way was } \\
\text { blocked }\end{array}$ \\
\hline & 675 & Najar Bik. Village & Khataye. Village & $\begin{array}{l}\text { People do not } \\
\text { live there }\end{array}$ \\
\hline \multirow[t]{5}{*}{ 19. Samangan } & 681 & Tatarchal. Village & Guldan. Village & $\begin{array}{l}\text { No village } \\
\text { found in such } \\
\text { name }\end{array}$ \\
\hline & 682 & Aka Khil. Village & Naktash. Village & $\begin{array}{l}\text { No village } \\
\text { found in such } \\
\text { name }\end{array}$ \\
\hline & 686 & Wetman. Village & Taqchi. Village & $\begin{array}{l}\text { No village } \\
\text { found in such } \\
\text { name }\end{array}$ \\
\hline & 688 & Deh Khwab. Village & Tangi Yaqub. Village & $\begin{array}{l}\text { Transportations } \\
\text { Problems }\end{array}$ \\
\hline & 689 & Adam Tash. Village & Tewa Tas. Village & $\begin{array}{l}\text { No village } \\
\text { found in such } \\
\text { name }\end{array}$ \\
\hline
\end{tabular}




\begin{tabular}{|c|c|c|c|c|}
\hline & 693 & Chah Khaki. Village & Alawdin. Village & $\begin{array}{l}\text { No transporta- } \\
\text { tion way for ve- } \\
\text { hicles }\end{array}$ \\
\hline \multirow[t]{2}{*}{ 20. Jozjan } & 705 & Darzab. District & Mingajik. District & $\begin{array}{l}\text { No transporta- } \\
\text { tion way for ve- } \\
\text { hicles }\end{array}$ \\
\hline & 706 & Darzab. District & Mingajik. District & $\begin{array}{l}\text { No transporta- } \\
\text { tion way for ve- } \\
\text { hicles }\end{array}$ \\
\hline \multirow[t]{8}{*}{ 21. Sar-i-Pul } & 713 & Sayad. District & $\begin{array}{l}\text { Sar-i-Pul -Town. Dis- } \\
\text { trict }\end{array}$ & $\begin{array}{l}\text { No transporta- } \\
\text { tion way for ve- } \\
\text { hicles }\end{array}$ \\
\hline & 714 & Sayad. District & $\begin{array}{l}\text { Sar-i-Pul -Town. Dis- } \\
\text { trict }\end{array}$ & $\begin{array}{l}\text { No transporta- } \\
\text { tion way for ve- } \\
\text { hicles }\end{array}$ \\
\hline & 715 & Balkhab. District & Sangcharak. District & $\begin{array}{l}\text { The district is } \\
\text { under control } \\
\text { of Taliban }\end{array}$ \\
\hline & 716 & Balkhab. District & Sangcharak. District & $\begin{array}{l}\text { The district is } \\
\text { under control } \\
\text { of Taliban }\end{array}$ \\
\hline & 725 & Kohistanat. District & Gosfandi. District & $\begin{array}{l}\text { The district is } \\
\text { under control } \\
\text { of Taliban }\end{array}$ \\
\hline & 726 & Kohistanat. District & Gosfandi. District & $\begin{array}{l}\text { The district is } \\
\text { under control } \\
\text { of Taliban }\end{array}$ \\
\hline & 727 & Kohistanat. District & Gosfandi. District & $\begin{array}{l}\text { The district is } \\
\text { under control } \\
\text { of Taliban }\end{array}$ \\
\hline & 728 & Kohistanat. District & Gosfandi. District & $\begin{array}{l}\text { The district is } \\
\text { under control } \\
\text { of Taliban }\end{array}$ \\
\hline \multirow[t]{4}{*}{ 22. Faryab } & 732 & Aqena. Village & Arab Shah. Village & $\begin{array}{l}\text { No village } \\
\text { found in such } \\
\text { name }\end{array}$ \\
\hline & 734 & Hur Tapa Hotor. Village & Sayer. Village & $\begin{array}{l}\text { No transporta- } \\
\text { tion way for ve- } \\
\text { hicles }\end{array}$ \\
\hline & 735 & $\begin{array}{l}\text { Ghar Tapa Amanullah } \\
\text { Khan. Village }\end{array}$ & Kopi Mareka. Village & $\begin{array}{l}\text { The village is } \\
\text { under control } \\
\text { of Taliban }\end{array}$ \\
\hline & 738 & $\begin{array}{l}\text { Mian Darakht Aji Zaren } \\
\text { Khan. Village }\end{array}$ & $\begin{array}{l}\text { Mian Dara Shamani. } \\
\text { Village }\end{array}$ & $\begin{array}{l}\text { The village is } \\
\text { under control } \\
\text { of Taliban }\end{array}$ \\
\hline
\end{tabular}




\begin{tabular}{|c|c|c|c|c|}
\hline & 741 & Bad Qaq. Village & Yakab. Village & $\begin{array}{l}\text { The village is } \\
\text { under control } \\
\text { of Taliban }\end{array}$ \\
\hline & 742 & Abdul Rahman. Village & Sofi Qala. Village & $\begin{array}{l}\text { The village is } \\
\text { under control } \\
\text { of Taliban }\end{array}$ \\
\hline & 743 & $\begin{array}{l}\text { Qalha Kuhna Kariz. Vil- } \\
\text { lage }\end{array}$ & Kohi. Village & $\begin{array}{l}\text { The village is } \\
\text { under control } \\
\text { of Taliban }\end{array}$ \\
\hline & 744 & $\begin{array}{l}\text { Kariz Mohammad Gul. } \\
\text { Village }\end{array}$ & Nawdari. Village & $\begin{array}{l}\text { The village is } \\
\text { under control } \\
\text { of Taliban }\end{array}$ \\
\hline & 745 & $\begin{array}{l}\text { Chahsma Yambalaq. Vil- } \\
\text { lage }\end{array}$ & $\begin{array}{l}\text { Arkhinak Payan. Vil- } \\
\text { lage }\end{array}$ & $\begin{array}{l}\text { The village is } \\
\text { under control } \\
\text { of Taliban }\end{array}$ \\
\hline & 748 & $\begin{array}{l}\text { Ali Zai Pir Mohammad. } \\
\text { Village }\end{array}$ & Nord Gul. Village & $\begin{array}{l}\text { The village is } \\
\text { under control } \\
\text { of Taliban }\end{array}$ \\
\hline & 749 & Jizartu. Village & Koh Sayad. Village & $\begin{array}{l}\text { No transporta- } \\
\text { tion way for ve- } \\
\text { hicles }\end{array}$ \\
\hline & 752 & Ghalbla Arabia. Village & $\begin{array}{l}\text { Dewana Khana. Vil- } \\
\text { lage }\end{array}$ & $\begin{array}{l}\text { No transporta- } \\
\text { tion way for ve- } \\
\text { hicles }\end{array}$ \\
\hline & 753 & Kofi Mir Shekar. Village & Dong Qalha. Village & $\begin{array}{l}\text { No village } \\
\text { found in such } \\
\text { name }\end{array}$ \\
\hline & 754 & Kohistan. District & Dawlat Abad. District & $\begin{array}{l}\text { No transporta- } \\
\text { tion way for ve- } \\
\text { hicles }\end{array}$ \\
\hline & 755 & Kohistan. District & Dawlat Abad. District & $\begin{array}{l}\text { No transporta- } \\
\text { tion way for ve- } \\
\text { hicles }\end{array}$ \\
\hline 31. Ghor & 780 & Saldiz. Village & Ghalmin Saliz. Village & $\begin{array}{l}\text { No transporta- } \\
\text { tion way for ve- } \\
\text { hicles }\end{array}$ \\
\hline \multirow[t]{3}{*}{ 32. Bamyan } & 797 & Sar qul Tupchi. Village & Dehan Zardak. Village & $\begin{array}{l}\text { No transporta- } \\
\text { tion way for ve- } \\
\text { hicles }\end{array}$ \\
\hline & 804 & $\begin{array}{l}\text { Hazar Chashma Pito. Vil- } \\
\text { lage }\end{array}$ & Sar Kang. Village & $\begin{array}{l}\text { No transporta- } \\
\text { tion way for ve- } \\
\text { hicles }\end{array}$ \\
\hline & 805 & Deh Yak. Village & Garmak. Village & $\begin{array}{l}\text { No transporta- } \\
\text { tion way for ve- } \\
\text { hicles }\end{array}$ \\
\hline
\end{tabular}




\begin{tabular}{|c|c|c|c|c|}
\hline & 806 & Qalha Ghashar. Village & Pora Jiya. Village & $\begin{array}{l}\text { No transporta- } \\
\text { tion way for ve- } \\
\text { hicles }\end{array}$ \\
\hline & 807 & Dara Mazar. Village & $\begin{array}{l}\text { Dehan Surkh Bid. Vil- } \\
\text { lage }\end{array}$ & $\begin{array}{l}\text { No transportation } \\
\text { way for vehicles }\end{array}$ \\
\hline & 808 & Gumbad. Village & Jo Polal. Village & $\begin{array}{l}\text { No transporta- } \\
\text { tion way for ve- } \\
\text { hicles }\end{array}$ \\
\hline & 810 & Kijak. Village & Dehan Sor. Village & $\begin{array}{l}\text { No village found } \\
\text { in such name }\end{array}$ \\
\hline \multirow[t]{7}{*}{ 34. Dehkhondi } & 816 & Zan Qafa. Village & Ab Bakhsh. Village & $\begin{array}{l}\text { No village found } \\
\text { in such name }\end{array}$ \\
\hline & 817 & Qunfak. Village & Pina. Village & $\begin{array}{l}\text { No village } \\
\text { found in such } \\
\text { name }\end{array}$ \\
\hline & 820 & Sar Tel Safla. Village & Siah Qul. Village & $\begin{array}{l}\text { Due to flood } \\
\text { the way was } \\
\text { blocked }\end{array}$ \\
\hline & 821 & Sabz Guli. Village & Qul Salan. Village & $\begin{array}{l}\text { Due to flood the } \\
\text { way was blocked }\end{array}$ \\
\hline & 822 & Gum Ab. Village & Sagafat. Village & $\begin{array}{l}\text { No village found } \\
\text { in such name }\end{array}$ \\
\hline & 823 & Rangin Darakht. Village & Barekak. Village & $\begin{array}{l}\text { There Were not } \\
\text { enough houses }\end{array}$ \\
\hline & 824 & Helsnio. Village & Zangab. Village & $\begin{array}{l}\text { No village found } \\
\text { in such name }\end{array}$ \\
\hline
\end{tabular}

\section{Selection of starting points within each sampling point}

The settlements within districts were selected at random by the field director. Each sampling point was assigned a starting point and given direction. The starting points were recognizable locations like mosques, schools, bazaars etc. within each of the selected settlements for the survey.

\section{Household Selection}

In urban areas, from the given starting point the interviewer headed in the assigned direction and stopped at the 1 st street/lane on the right hand side of his/her route. From there on, the 2 nd contacted household was the fourth house on the right from the beginning of the street. Further on, the selected household was each 3rd inhabitable house on the right side of the interviewer's route. In apartment buildings the selection method was each 5 th apartment 
In rural areas, the interviewer started from the center of the village or the bazaar, mosque, etc. and went to the right selecting each 3rd inhabitable house on his/her route. Compounds containing two or more houses behind a common wall were treated as detached houses, counting them counter-clock-wise from the gate to the compound.

\section{Respondent Selection}

After selecting a household, interviewers used a Kish grid for randomizing the target respondent within the household. Members of the household were listed with their names and ages in descending order.

\section{Respondent Substitution}

Using the Kish Grid, under no circumstances were interviewers allowed to substitute an alternate member of a household for the selected respondent. If the respondent refused to participate or was not available after callbacks, the interviewer moved on to the next household according to the random walk.

\section{Call-backs (rate, method, and results)}

Typically interviewers were required to make two call-backs before replacing the designated respondent. Due to security-related fears in previous deployments field researchers had difficulty meeting the requirement of two call-backs prior to substitution. In this survey, while field researchers were able to complete some call-backs, the majority of the interviews were completed on the first attempt (98.6\%), 1.1\% of the interviews were completed on the second attempt, and $0.3 \%$ of interviews were completed on the third attempt. Due to the high rate of unemployment, and choosing the appropriate time of day for interviewing, completion on the first attempt is the norm in Afghanistan.

\section{Training of Interviewers}

ACSOR first held extended training sessions with supervisors and assistant supervisors on the Interviewers' Manual which covers all the main aspects and techniques of the field researchers' work. This was followed by a briefing for interviewers on the survey questionnaire. At the end of the detailed review of the questionnaire each supervisor conducted a monitored mock interview in the office, and was further assigned to conduct a pilot interview in the field. 
On the next day, the completed pilot interviews were reviewed for proper administration. A briefing session was held to discuss any problems discovered during the pilot interviews. Each supervisor repeated the entire process with the interviewers in the respective province. The training typically lasted two to three days.

The briefings with supervisors were held in Kabul. Each supervisor then organized his/her own briefing sessions with the interviewers. The briefing on the main questions was conducted by the Project Managers Mr. Haroon Tahiri and Mr. Jameel Rahmany. The Field Managers, Mr. Toryalai Tajmal Zai and Mr. Rahmatullah Faizi reviewed the sampling procedures. Mr. Matthew Warshaw provided guidance and monitored the sessions in Kabul and The Asia Foundation staff and consultants attended briefings as well. Issues emphasized during the briefing were: a) proper household and respondent selection, b) review of the questionnaire content, c) appropriate interviewing techniques, and d) conducting pilot interviews to master logic and concept of questions.

\section{Refusals/Non-Contacts/Completed Interviews}

\begin{tabular}{|l|c|c|}
\hline \multicolumn{1}{|c|}{ Result Category } & Number & $\begin{array}{c}\% \text { of } \\
\text { Category }\end{array}$ \\
\hline Non-Contact & 239 & 3 \\
\hline No one at home after three visits & 639 & 8 \\
\hline Respondent long -term absence /for the field work period & 227 & 2.8 \\
\hline No adults (18+)after three visits & 1105 & 13.8 \\
\hline Sub-Total & & \\
\hline Refusals & 140 & 1.7 \\
\hline Not feeling informed to answer the questions & 118 & 1.5 \\
\hline Prefers head of the house to be interviewed & 151 & 1.9 \\
\hline In a hurry/ No time & & \\
\hline $\begin{array}{l}\text { Respondent got angry because of a question and aborted } \\
\text { interview }\end{array}$ & & 81 \\
\hline Sub-Total & 409 & 5.1 \\
\hline Completed Interviews & 7967 & 100 \\
\hline Total Contact Attempts & & 891 \\
\hline
\end{tabular}




\section{Quality Control Methods}

After the return of the questionnaires from the field, most of the completed questionnaires were subject to logical control for proper administration.

Actual interviewing was monitored directly by a supervisor for $6.4 \%$ of the sample. Another $23.9 \%$ of the completed interviews were back-checked by a supervisor in person. $1.3 \%$ of the completed interviews were back-checked from ACSOR's central office. The issues verified during in person back-checks included proper household and respondent selection and correct recording of answers to five randomly selected questions from the main body of the questionnaire.

In total, 75 interviews were rejected due to the low quality of interviewers' work. Out of these, 3 interviews were deleted due to over 40\% 'don't know' answers in the substantive and demographic sections, and other 71 interviews were deleted due to over $95 \%$ similarities in the substantive body plus demographic sections. One interviewer was terminated from Herat province after his work was back-checked and considered to be very poor. The sampling point which was conducted by this interviewer was re-conducted by another interviewer.

\section{Weighting}

The data set includes a weight to adjust for over-sampling and under-sampling at the provincial level. The data was weighted to be representative of national population distribution according to the population statistics available from the Afghan Central Statistics Office. Below is the entire list of weights assigned to rural and urban areas by province.

\begin{tabular}{l|c|c|}
\multirow{2}{*}{ Province } & \multicolumn{2}{c}{ Weighting Factor } \\
\cline { 2 - 3 } & Rural & Urban \\
\hline Kabul & 1.05173871 & 1.03198431 \\
\hline Kapisa & 1.04713488 & . \\
\hline Parwan & 1.02202014 & 1.00282393 \\
\hline Wardak & 1.03033593 & . \\
\hline Logar & 0.92394254 & 1.03404792 \\
\hline Ghazni & 1.05384182 & 0.97886192 \\
\hline Paktia & 0.99759945 &. \\
\hline Paktika & 1.25174745 & 1.04865782 \\
\hline Khost & 1.06873138 & . \\
\hline
\end{tabular}




\begin{tabular}{|c|c|c|}
\hline Ningarhar & 1.02539635 & 1.00613673 \\
\hline Laghman & 1.04713488 & . \\
\hline Kunar & 0.97233954 & . \\
\hline Nooristan & 0.35262394 & . \\
\hline Badakhshan & 1.00771821 & 0.98879063 \\
\hline Takhar & 1.07542261 & 1.05522336 \\
\hline Baghlan & 1.05616826 & 1.03633066 \\
\hline Kunduz & 1.03153690 & 1.01216194 \\
\hline Balkh & 1.03922357 & 1.01970424 \\
\hline Samangan & 0.87429206 & 0.85787058 \\
\hline Juzjan & 1.19106055 & 1.16868932 \\
\hline Sar-I-Pul & 0.99025604 & 0.97165645 \\
\hline Faryab & 1.21380692 & 1.19100846 \\
\hline Badghis & 1.01428359 & . \\
\hline Herat & 1.07732556 & 1.05709058 \\
\hline Farah & 1.02410003 & 1.00486476 \\
\hline Nimroz & 0.34971683 & 0.34314823 \\
\hline Helmand & 1.02519695 & 1.00594108 \\
\hline Kandahar & 1.08230925 & 1.06198066 \\
\hline Zabul & 0.72585078 & 0.71221740 \\
\hline Uruzhan & 0.85936827 & 0.84322709 \\
\hline Ghor & 1.05464661 & . \\
\hline Bamyan & 0.97364571 & 0.95535810 \\
\hline Panjshir & 0.35588898 & . \\
\hline Dehkondi & 1.04968861 & 1.02997272 \\
\hline
\end{tabular}




\section{Appendix 3: Interview Questionnaire}

\section{Region}

\begin{tabular}{l|c}
\hline Base: All respondents $\mathbf{6 4 6 7}$ & (\%) \\
\hline Central/Kabul & 23 \\
\hline Eastern & 10 \\
\hline South East & 11 \\
\hline South Western & 11 \\
\hline Western & 14 \\
\hline North East & 15 \\
\hline Central/Hazarjat & 4 \\
\hline North West & 14
\end{tabular}

\section{Geographic Code}

\begin{tabular}{l|c|}
\hline Base: All respondents $\mathbf{6 4 6 7}$ & $\mathbf{( \% )}$ \\
\hline Village & 78 \\
\hline Town & 5 \\
\hline City & 5 \\
\hline Metro (Kabul) & 11 \\
\hline
\end{tabular}

\section{Province}

\begin{tabular}{|l|c|}
\hline Base: All respondents $\mathbf{6 4 6 7}$ & $(\mathbf{\%})$ \\
\hline Kabul & 14 \\
\hline Kapisa & 2 \\
\hline Parwan & 3 \\
\hline Wardak & 2 \\
\hline Logar & 2 \\
\hline Ghazni & 5 \\
\hline Paktia & 2 \\
\hline Paktika & 2 \\
\hline Khost & 2 \\
\hline Ningarhar & 6 \\
\hline Laghman & 2 \\
\hline Kunar & 2 \\
\hline Nooristan & 1 \\
\hline Badakhshan & 4 \\
\hline Takhar & 4 \\
\hline Baghlan & 4 \\
\hline Kunduz & 4 \\
\hline Balkh & 5
\end{tabular}




\begin{tabular}{|l|l|}
\hline Samangan & 2 \\
\hline Juzjan & 2 \\
\hline Sar-i-Pul & 2 \\
\hline Faryab & 4 \\
\hline Badghis & 2 \\
\hline Herat & 7 \\
\hline Farah & 2 \\
\hline Nimroz & 1 \\
\hline Helmand & 4 \\
\hline Kandhar & 5 \\
\hline Zabul & 1 \\
Uruzgan & 1 \\
Ghor & 3 \\
Bamyan & 2 \\
Panjshir & 1 \\
Dikundi & 2 \\
\hline
\end{tabular}

\section{NOTE TO INTERVIEWERS:}

REMEMBERTHATTHIS IS A CONVERSATION. MAKETHERESPONDENT COMFORTABLE. MAKE EYE CONTACT.

DO NOT TRY TO LEAD THE RESPONDENT DURING THE INTERVIEW OR GET THE "DESIRED” ANSWERS FROM THEM. MAKE SURE YOU TELL THEM THAT THERE ARE NO RIGHT OR WRONG ANSWERS, YOU JUST WANT THEIR OPINIONS.

DURING THE INTERVIEW, BE POLITE BUT INQUISITIVE. DO NOT ACCEPT ONE-WORD ANSWERS. DRAW OUT RESPONDENTS TO GIVE DETAILED RESPONSES BY FURTHER PROBING - SAY: "WHY DO YOU SAY THAT?” “ANYTHING ELSE?” "TELL ME MORE.”

Asalaam-u-Alikum, I am from ACSOR-Surveys, an independent research organization. We regularly conduct surveys among people like you to find out what you feel about issues of public interest. ACSOR-Surveys has no relation to the government. I just want to ask you some questions about "matters of interest to Afghans". I am interested in your opinion. Your answers will be kept confidential and your name will not be given to anyone and your views will be analyzed along with those of thousands of others. 
W-1. Do you listen to radio programs?

\begin{tabular}{l|c} 
Base: All respondents $\mathbf{6 4 6 7}$ & $(\%)$ \\
\hline Yes & 79 \\
No & 21 \\
Refused & $*$ \\
\hline Don't know & $*$
\end{tabular}

W-2. Do you watch television programs?

\begin{tabular}{lc} 
Base: All respondents $\mathbf{6 4 6 7}$ & $(\mathbf{\%})$ \\
\hline Yes & 40 \\
No & 59 \\
Refused & $*$ \\
Don't know & $*$
\end{tabular}

W-3. Which of the following sources do you use most often for news and information?

\begin{tabular}{|l|c|}
\hline Base: All respondents $\mathbf{6 4 6 7}$ & $\mathbf{( \% )}$ \\
\hline Television & 28 \\
\hline Radio & 46 \\
\hline Newspaper & 1 \\
\hline Internet & $*$ \\
\hline Mosque & 6 \\
\hline Friends and family & 19 \\
\hline Other sources & $*$ \\
\hline Refused & $*$ \\
\hline Don't know & $*$
\end{tabular}

Q-1. Do you own any of the following here in your household in functioning order?

\begin{tabular}{|l|r|r|r|r|}
\hline & \multicolumn{1}{|c|}{ Yes } & \multicolumn{1}{|c|}{ No } & Refused & Don't Know \\
\hline Base: All respondents 6467 & \multicolumn{1}{|c|}{$(\mathbf{\%})$} & \multicolumn{1}{c|}{$(\mathbf{\%})$} & $\mathbf{( \% )}$ & $\mathbf{( \% )}$ \\
\hline a) Radio & 82 & 18 & \\
\hline b) TV set & 41 & 59 & \\
\hline c) Fixed phone line & $*$ & 99 & \\
\hline d) Mobile phone & 59 & 41 & \\
\hline e) Bicycle & 50 & 50 & \\
\hline
\end{tabular}



f) Motorcycle
35
65
g) Computer
9
91
h) Car
17
83

Q-2. If you wanted to find out about something important happening in your community, who, outside your family, do you ask? [Do Not Read Out Answers]

Write Answer:

\begin{tabular}{l|c|}
\hline Base: All respondents $\mathbf{6 4 6 7}$ & $\mathbf{( \% )}$ \\
\hline Mullah & 11 \\
\hline Village chief/ Community leader & 12 \\
\hline Worker at community centers (school, health center, etc.) & 1 \\
\hline Friend & 26 \\
Co-workers & 4 \\
\hline Shopkeepers & 3 \\
\hline Neighbors/ villagers & 20 \\
\hline Local Afghan Radio stations & 10 \\
\hline International radio stations (such as BBC, Azadi, or Ashna) & 10 \\
\hline TV stations & 2 \\
\hline No one & $*$ \\
Police & $*$ \\
Don't know & $*$
\end{tabular}

Q-3. People get information about news and current events from many different sources. For each one of the sources I mention, please tell me how often you use that source to get news and information about current events: daily /most days a week, 3 or 4 days a week, 1 or 2 days a week, less than once per week, or never?

\begin{tabular}{|c|c|c|c|c|c|c|c|}
\hline \multirow[t]{2}{*}{$\begin{array}{l}\text { Base: All } \\
\text { respondents } \\
6467\end{array}$} & $\begin{array}{l}\text { Every day } \\
\text { or almost } \\
\text { every day }\end{array}$ & $\begin{array}{c}3 \text { or } 4 \text { days } \\
\text { a week }\end{array}$ & $\begin{array}{c}1 \text { or } 2 \text { days } \\
\text { a week }\end{array}$ & $\begin{array}{c}\text { Less than } \\
\text { once a } \\
\text { week }\end{array}$ & Never & Refused & $\begin{array}{l}\text { Don't } \\
\text { Know }\end{array}$ \\
\hline & $(\%)$ & $(\%)$ & $(\%)$ & $(\%)$ & $(\%)$ & $(\%)$ & $(\%)$ \\
\hline a) Newspapers & 2 & 3 & 4 & 9 & 81 & * & 1 \\
\hline b) Magazines & 1 & 2 & 4 & 9 & 83 & $*$ & 1 \\
\hline c) The Internet & & $*$ & & * & 98 & & 2 \\
\hline $\begin{array}{l}\text { d) SMS (text } \\
\text { messaging on } \\
\text { mobile) }\end{array}$ & 1 & 3 & 5 & 16 & 74 & * & 1 \\
\hline $\begin{array}{l}\text { e) Meetings } \\
\text { in your } \\
\text { community }\end{array}$ & 4 & 13 & 16 & 24 & 42 & * & 1 \\
\hline
\end{tabular}


f) Meetings or sermons at your mosque

g) Radio

h) Television

14
43
27

1

\begin{tabular}{l|l|}
\hline 16 & 16 \\
\hline 21 & 12 \\
\hline 9 & 7 \\
\hline
\end{tabular}

\begin{tabular}{|l|l|}
\hline 15 & 38 \\
\hline 5 & 17 \\
\hline 6 & 51 \\
\hline
\end{tabular}

Q-4. Generally speaking, do you think things in Afghanistan today are going in the right direction, or do you think they are going in the wrong direction?

Base: All respondents 6467

Right direction

Wrong direction

Some in right, some in wrong direction

Refused

Don't know
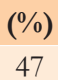

27

22

4

Q-5a. (Filtered. If ' 1 ' in Q-4): Why do you say that things are moving in the right direction? (Do NOT read codes. Write down answer)

Write $1^{\text {st }}$ Mention:

Q-5b. (Filtered. If ' 1 ' in Q-4): Why else? (Do NOT read codes. Write down answer)

Write 2nd Mention:

[Do not print list in final questionnaire]

\begin{tabular}{|l|c|c|}
\hline Base: Right direction $\mathbf{3 0 2 0}$ & $\begin{array}{c}\text { Q-5a. } \\
\mathbf{1}^{\text {st }} \text { mention }\end{array}$ & $\begin{array}{c}\text { Q-5a \& b. } \\
\mathbf{1}^{\text {st }} \mathbf{\&} \mathbf{2}^{\text {nd }} \text { mention }\end{array}$ \\
\hline Peace / end of the war & $\mathbf{( \% )}$ & $\mathbf{( \% )}$ \\
\hline Disarmament & 7 & 12 \\
\hline Good security & 1 & 2 \\
Reconstruction / rebuilding & 26 & 38 \\
\hline Free movement / travel possible & 20 & 35 \\
\hline Economic revival & 1 & 2 \\
\hline Freedom / free speech & 4 & 10 \\
\hline Democracy / elections & 1 & 4 \\
\hline Schools for girls have opened & 4 & 7 \\
Women can now work & 7 & 15 \\
\hline Women have more freedom & $*$ & 1 \\
\hline Refugees return & 1 & 1 \\
\hline Good government & $*$ & 1 \\
International assistance & 5 & 9 \\
& 1 & 3
\end{tabular}




\begin{tabular}{l|c|c|}
\hline Reduction in level of administrative & 1 & 3 \\
corruption & 1 & 2 \\
Reduction in poppy cultivation & 3 & 6 \\
\hline Having active ANA and ANP & $*$ & 1 \\
Removing the terrorism & 1 & 3 \\
\hline Having a legal constitution & $*$ & 1 \\
More attention to human rights & 3 & 7 \\
Road reconstruction & 1 & 1 \\
Clinics have been built & $*$ & 1 \\
Development in agriculture system & 1 & 3 \\
More job opportunities available & $*$ & 1 \\
Development in healthcare system in general & 1 & 2 \\
Having Parliament & $*$ & 1 \\
More electricity supply now than before & 1 & 2 \\
National unity & $*$ & $*$ \\
Respecting Islam & 1 & 2 \\
Removing the Taliban & $*$ & $*$ \\
Better treatment for addicts & 5 & 10 \\
Improvement in education system & $*$ & $*$ \\
Good communication system & $*$ & $*$ \\
Clean drinking water & $*$ & 1 \\
Having better relations with foreign countries & 1 & 1 \\
Don't know & &
\end{tabular}

Q-6a. (Filtered. If "Wrong direction" in Q-4): Why do you say that things are moving in the wrong direction?

(Do NOT read codes. Write down answer)

Write $1^{\text {st }}$ Mention:

Q-6b. (Filtered. If '2' in Q-4): Why else? (Do NOT read codes. Write down answer)

Write $2^{\text {nd }}$ Mention:

[Do not print list in final questionnaire]

\begin{tabular}{|l|c|c|} 
& $\begin{array}{c}\text { Q-6a. } \\
\mathbf{1}^{\text {st }} \text { mention }\end{array}$ & $\begin{array}{c}\text { Q-6a \& b. } \\
\mathbf{1}^{\text {st }} \boldsymbol{\&} \mathbf{2}^{\text {nd }} \text { mention }\end{array}$ \\
\hline Base: Wrong direction $\mathbf{1 7 4 7}$ & $\mathbf{( \% )}$ & $\mathbf{( \% )}$ \\
\hline No reconstruction has happened & 2 & 4 \\
\hline There is no progress & $*$ & 1 \\
\hline Lack of aid / no development assistance & 1 & 2 \\
\hline Bad economy & 3 & 8 \\
\hline Poor education system & 2 & 5 \\
\hline Too many foreigners are getting involved & 3 & 5 \\
\hline Foreign aid causes problems & 1 & 2 \\
\hline Western influence is too great & 2 & 3 \\
\hline There is danger to Islam & 1 & 1 \\
\hline
\end{tabular}




\begin{tabular}{|c|c|c|}
\hline Neighboring countries cause problems & $*$ & 1 \\
\hline Bad government & 10 & 18 \\
\hline Corruption & 14 & 27 \\
\hline Poor leadership & 1 & 2 \\
\hline There is unemployment & 5 & 16 \\
\hline Presence of Taliban & 3 & 6 \\
\hline $\begin{array}{l}\text { Lack of coordination between ISAF/ } \\
\text { Coalition forces and ANP/ANA during } \\
\text { fights with AGE }\end{array}$ & 2 & 3 \\
\hline Insecurity & 33 & 44 \\
\hline Disarmament didn't take place & $*$ & 1 \\
\hline Presence of Warlords & 1 & 2 \\
\hline $\begin{array}{l}\text { People disenchanted with the } \\
\text { government }\end{array}$ & 1 & 2 \\
\hline Increase in level of drug trade & 1 & 3 \\
\hline High price & 1 & 2 \\
\hline Innocent people being killed & 2 & 5 \\
\hline Kidnapping children & $*$ & 1 \\
\hline Ethnic problems & 2 & 3 \\
\hline Lack of shelter & * & $*$ \\
\hline Water and power problems & 1 & 1 \\
\hline Too much luxury & 1 & 1 \\
\hline Suicide attacks & 4 & 8 \\
\hline Unfair elections & $*$ & 1 \\
\hline Terrorism & $*$ & 1 \\
\hline Lack of freedom of speech & * & * \\
\hline Injustice in the country & 1 & 1 \\
\hline Lack of unity & $*$ & 2 \\
\hline Women's rights & $*$ & 1 \\
\hline Health care problems & & * \\
\hline Lack of communication system & & $*$ \\
\hline Transportation problem & & $*$ \\
\hline Don't know & 2 & 2 \\
\hline
\end{tabular}

Q-7a. (ASK ALL) In your view, what is the biggest problem facing Afghanistan as a whole? (Do NOT read codes. Write down answer) Write 1st Mention:

Q-7b. And after that, what is the next biggest problem? (Do NOT read codes. Write down answer Write 2nd Mention: [Do not print list in final questionnaire] 


\begin{tabular}{|c|c|c|}
\hline \multirow{2}{*}{ Base: All respondents 6467} & $\begin{array}{c}\text { Q-7a. } \\
\text { First problem }\end{array}$ & $\begin{array}{c}\text { Q-7b. } \\
\text { Next problem }\end{array}$ \\
\hline & $(\%)$ & $(\%)$ \\
\hline Insecurity / attacks / violence/ terrorism & 24 & 37 \\
\hline Presence of warlords & 1 & 2 \\
\hline Presence of Taliban & 5 & 8 \\
\hline Poor Economy & 5 & 11 \\
\hline Poverty & 5 & 10 \\
\hline Unemployment & 13 & 28 \\
\hline Reconstruction / rebuilding & 1 & 2 \\
\hline Education / schools / literacy & 5 & 11 \\
\hline $\begin{array}{l}\text { Government / weak government / central } \\
\text { authority }\end{array}$ & 3 & 5 \\
\hline Corruption & 14 & 27 \\
\hline Scarcity of electricity & 2 & 4 \\
\hline Roads & 1 & 2 \\
\hline Health care / clinics / hospitals & 1 & 1 \\
\hline Drinking water & 1 & 1 \\
\hline Water for irrigation & $*$ & * \\
\hline High prices & 1 & 4 \\
\hline Lack of (proper) shelter & 1 & 1 \\
\hline Drugs smuggling & 3 & 6 \\
\hline Crime & 1 & 1 \\
\hline Interference of foreign countries & 4 & 7 \\
\hline Lack of production companies & * & * \\
\hline Tribe/ Partisanship & * & * \\
\hline Agricultural problems & * & $*$ \\
\hline Transportation problems & * & * \\
\hline Lack foreign assistances & * & * \\
\hline Lack efficient ANA and ANP & * & 1 \\
\hline Returnees problems & * & * \\
\hline Disrespect to our culture & * & $*$ \\
\hline Kidnapping children & * & 1 \\
\hline Innocent people being killed & * & 1 \\
\hline No problems & * & * \\
\hline Too much luxury & * & * \\
\hline Low salary for the government employees & * & * \\
\hline No freedom & * & $*$ \\
\hline Irresponsible armed people & * & * \\
\hline No attention to women rights & $*$ & $*$ \\
\hline Injustice & 1 & 2 \\
\hline Suicide attacks & 2 & 5 \\
\hline Disrespect for Islamic laws & * & $*$ \\
\hline Existence of private prisons & * & * \\
\hline Lack of national unity & $*$ & 1 \\
\hline
\end{tabular}




\begin{tabular}{l|c|c|}
\hline Discriminations & 2 & 3 \\
\hline Interference of Pakistan & 1 & 1 \\
\hline Interference of Iran & $*$ & $*$ \\
Lack of respect to elders & $*$ & 1 \\
Presence of foreign troops & & $*$ \\
Municipalities not doing their job well & $*$ & 2 \\
Refused & 2 & $*$ \\
Don't Know & &
\end{tabular}

Q-8a. (ASK ALL) What is the biggest problem in your local area? (Do NOT Read codes. Write down answer)

Write 1st Mention:

Q-8b. And what is the next biggest problem in your local area? (Do NOT Read codes. Write down answer and then code in the second column below) Write 2nd Mention:

[Do not print list in final questionnaire]

\begin{tabular}{|c|c|c|}
\hline Base: All respondents 6467 & $\begin{array}{l}\text { Q-8a. } \\
\text { First problem in the } \\
\text { area } \\
(\%)\end{array}$ & $\begin{array}{c}\text { Q-8b. } \\
\text { Next problem } \\
\text { in the area } \\
(\%)\end{array}$ \\
\hline Insecurity / attacks / violence & 8 & 13 \\
\hline Presence of warlords & 1 & 1 \\
\hline Taliban & 1 & 2 \\
\hline Poor Economy & 2 & 4 \\
\hline Poverty & 3 & 6 \\
\hline Unemployment & 15 & 26 \\
\hline Reconstruction / rebuilding & 2 & 4 \\
\hline Education / schools / literacy & 8 & 16 \\
\hline $\begin{array}{l}\text { Government / weak government / central } \\
\text { authority }\end{array}$ & 1 & 1 \\
\hline Corruption & 1 & 2 \\
\hline Electricity & 15 & 28 \\
\hline Roads & 12 & 24 \\
\hline Health care / clinics / hospitals & 7 & 17 \\
\hline Drinking Water & 12 & 22 \\
\hline High prices & 2 & 4 \\
\hline Lack of (proper) shelter & 1 & 1 \\
\hline Drugs smuggling & $*$ & 1 \\
\hline Crime & 1 & 1 \\
\hline Transportation problems & $*$ & 1 \\
\hline Lack of agricultural tools / equipment & $*$ & 1 \\
\hline No problems & 1 & 1 \\
\hline Presence of foreigners & * & * \\
\hline Natural disasters & $*$ & * \\
\hline
\end{tabular}




\begin{tabular}{|c|c|c|}
\hline Lack of foreign assistance & $*$ & * \\
\hline Kidnapping children & $*$ & $*$ \\
\hline Innocent people being killed & 1 & 1 \\
\hline Ethnic problems & 1 & 2 \\
\hline Water for irrigation & 1 & 3 \\
\hline Returnees' problems & $*$ & * \\
\hline Women rights & $*$ & * \\
\hline Addiction to drugs & $*$ & * \\
\hline Lack of communication system & $*$ & * \\
\hline Lack of bakeries & $*$ & * \\
\hline Interference of Pakistan & $*$ & * \\
\hline Lack of entertainment opportunities & $*$ & * \\
\hline Municipalities not doing their job well & 2 & 3 \\
\hline Lack of mosques & $*$ & * \\
\hline People not feeling responsibility & $*$ & * \\
\hline Lack of industrial programs & $*$ & * \\
\hline Injustice & $*$ & * \\
\hline Gas & * & * \\
\hline $\begin{array}{l}\text { Arbakis ( Armed groups supported by the } \\
\text { government) }\end{array}$ & $*$ & * \\
\hline Lack of unity & $*$ & * \\
\hline Lack of banking system & $*$ & * \\
\hline Refused & $*$ & * \\
\hline Don’t Know & 1 & 1 \\
\hline
\end{tabular}

Q-9. Which one of following issues is more critical or important to your needs at present? Please, rank in order of priority, whereby the most important rank as ' 1 ', the next important rank as '2' and so on, up to the least important as '5'. (Show Card and read responses)

\section{Base: All respondents 6467}

Roads

Power

Water

Health care

Education

Don't know
Average importance Rank

2.8

2.9

2.9

3.1

3.2

$1(\%)$ 
Q-10. I would like to ask you about today's conditions in the village/ neighborhood where you live. Would you rate

(insert item here) as very good, quite good, quite bad, or very bad in your area?

\section{Base: All respondents 6467}

a) The availability of clean drinking water

b) The availability of water for irrigation

c) The availability of jobs

d) The supply of electricity

e) The security situation

f) The availability of clinics and hospitals

g) The availability of medicine

h) The availability of education for children

i) Your freedom of movement-the ability to move safely in your area or district

\begin{tabular}{|c|c|c|c|c|c|}
\hline VG & QG & QB & VB & Ref. & DK \\
\hline $\mathbf{( \% )}$ & $\mathbf{( \% )}$ & $\mathbf{( \% )}$ & $\mathbf{( \% )}$ & $\mathbf{( \% )}$ & $\mathbf{( \% )}$ \\
\hline 23 & 40 & 25 & 12 & & $*$ \\
\hline 14 & 35 & 31 & 16 & & 3 \\
\hline 5 & 22 & 38 & 34 & & 1 \\
\hline 15 & 19 & 25 & 41 & & 1 \\
\hline 26 & 39 & 20 & 13 & & 2 \\
\hline 10 & 36 & 36 & 17 & & 1 \\
\hline 10 & 33 & 38 & 17 & $*$ & 1 \\
\hline 23 & 45 & 22 & 10 & & 1 \\
\hline 24 & 39 & 24 & 12 & $*$ & 1 \\
\hline
\end{tabular}

Q-11a. (ASK ALL) Various projects and programs have been implemented or are being implemented in some places of our country. Speaking of the past 12 months, do you know of, heard of any project or program in this area, district, implemented in the following fields?

Base: All respondents 6467

\begin{tabular}{|c|c|c|}
\hline Yes & No & Ref/ \\
\hline $\mathbf{( \% )}$ & $\mathbf{( \% )}$ & $\mathbf{( \% )}$ \\
\hline 54 & 46 & $*$ \\
\hline 43 & 56 & 1 \\
\hline 27 & 71 & 2 \\
\hline 28 & 70 & 2 \\
\hline 39 & 60 & 1 \\
\hline 54 & 45 & 1 \\
\hline 30 & 68 & 2 \\
\hline 28 & 69 & 3 \\
\hline 26 & 72 & 2 \\
\hline 15 & 82 & 3 \\
\hline 28 & 70 & 2 \\
\hline 23 & 74 & 3 \\
\hline & 55 & 45 \\
\hline
\end{tabular}

a) Reconstruction/ building of roads, bridges

b) Water supply for drinking

c) Water supply for irrigation

d) Electricity supply

e) Healthcare (primary health center, regular visits of doctors, etc.)

f) Education (reconstruction/opening of school, more teachers etc.)

g) De-mining

h) Demilitarization / disarmament

i) Reconstruction/ programs in agriculture

j) Reconstruction/ programs in industry

k) Building new mosques

l) Humanitarian programs - help in food, medicines, shelter, production materials etc.

m) Other 
Q-11b. (If answered "Yes", Code 1, in Q-11a, ASK) Has the Afghan Government or Foreign sponsors been primarily responsible for providing most of the aid for the projects?

Base: All respondents 6467

\begin{tabular}{|c|c|c|c|}
$\begin{array}{c}\text { Afghan } \\
\text { Gov. }\end{array}$ & $\begin{array}{c}\text { Foreign } \\
\text { Sponsor }\end{array}$ & Both & $\begin{array}{c}\text { Ref/ } \\
\text { DK }\end{array}$ \\
\hline $\mathbf{( \% )}$ & $(\%)$ & $(\%)$ & $(\%)$ \\
\hline
\end{tabular}

a) Reconstruction/ building of roads, bridges

38

33

24

5

b) Water supply for drinking

46

30

19

5

c) Water supply for irrigation

50

d) Electricity supply

58

24

20

5

e) Healthcare (primary health center, regular visits of doctors, etc.)

18

17

f) Education (reconstruction/opening of school, more teachers etc.)

\begin{tabular}{|l|l|l|l|}
\hline 55 & 17 & 22 & 6 \\
\hline 32 & 39 & 24 & 6 \\
\hline
\end{tabular}

g) De-mining

h) Demilitarization / disarmament

46

24

i) Reconstruction/ programs in agriculture

j) Reconstruction/ programs in industry

k) Building new mosques

42

66

31

l) Humanitarian programs - help in food, medicines, shelter, production materials etc.

m) Other

Q-12. Turning to another subject, tell me, do you strongly agree, agree somewhat, disagree somewhat or strongly disagree with the following statements?

Base: All respondents 6467

a) I don't think that the government cares much about what people like me think

b) It is generally not acceptable to talk negatively about the Government in public

\begin{tabular}{|c|c|c|c|c|c|}
\hline SA & AS & DS & SD & Ref. & DK \\
\hline $\mathbf{( \% )}$ & $(\%)$ & $(\%)$ & $(\%)$ & $(\%)$ & $(\%)$ \\
\hline
\end{tabular}

\begin{tabular}{|l|l|l|l|l|l|}
30 & 44 & 18 & 6 & $*$ & 2
\end{tabular}


Q-13. (ASK ALL) Now I would like to ask you a few questions about the economy of Afghanistan. If you think about your family, would you say that today your family is more prosperous, less prosperous, or about as prosperous as under the Taliban government?

\begin{tabular}{l|c|}
\hline Base: All respondents $\mathbf{6 4 6 7}$ & $\mathbf{( \% )}$ \\
\hline More prosperous & 41 \\
\hline Less prosperous & 36 \\
\hline About as prosperous under the Taliban & 16 \\
Govt. & 5 \\
\hline Absent during Taliban rule & $*$ \\
\hline Refused & 1
\end{tabular}

Q-14. Compared to one year ago, would you say that situation for your household has gotten better, remained the same or gotten worse with respect to the following?

Base: All respondents 6467

\begin{tabular}{|c|c|c|c|c|}
\hline Better & $\begin{array}{c}\text { The } \\
\text { same }\end{array}$ & Worse & Ref. & DK \\
\hline $\mathbf{( \% )}$ & $\mathbf{( \% )}$ & $\mathbf{( \% )}$ & $\mathbf{( \% )}$ & $\mathbf{( \% )}$ \\
\hline 42 & 49 & 9 & $*$ & $*$ \\
\hline 17 & 44 & 38 & $*$ & 1 \\
\hline 27 & 49 & 22 & $*$ & 2 \\
\hline 33 & 50 & 16 & $*$ & 1 \\
\hline 25 & 54 & 20 & $*$ & 1 \\
\hline 35 & 46 & 18 & $*$ & 1 \\
\hline 23 & 36 & 40 & $*$ & 1 \\
42 & 42 & 15 & $*$ & 1 \\
\hline
\end{tabular}

Q-15. How often do you fear for your own personal safety or security or for that of your family these days? Often, sometimes, rarely, or never?

\begin{tabular}{l|c|} 
Base: All respondents $\mathbf{6 4 6 7}$ & $\mathbf{( \% )}$ \\
\hline Often & 18 \\
\hline Sometimes & 36 \\
\hline Rarely & 20 \\
\hline Never & 26 \\
\hline Refused & $*$ \\
\hline Don't know & 1
\end{tabular}


Q-16. Have you or has anyone in your family been a victim of violence or of some criminal act in your home or community in the past year?

\begin{tabular}{|l|c|}
\hline Base: All respondents $\mathbf{6 4 6 7}$ & $\mathbf{( \% )}$ \\
\hline Yes & 17 \\
\hline No & 80 \\
Refused & 1 \\
\hline Don't know & 2
\end{tabular}

Q-17. (Filtered. Ask if answered '1' in Q-16) What kind of violence or crime did you or someone in your family experience in the past year? READ LIST (Multiple Response)

\begin{tabular}{ll|}
\hline Base: Victims $\mathbf{1 1 1 4}$ & (\%) \\
\hline Physical attack or beating & 35 \\
\hline Racketeering / extortion & 12 \\
\hline Burglary/looting & 12 \\
\hline Pick-pocketing & 10 \\
\hline $\begin{array}{l}\text { Motor vehicle theft / Property taken from your vehicle or } \\
\text { parts of the vehicle stolen }\end{array}$ & 7 \\
\hline Kidnapping & 6 \\
\hline Livestock stolen & 12 \\
\hline Militants/Insurgent actions & 9 \\
\hline Police actions & 4 \\
\hline Army actions & 1 \\
\hline Foreign forces actions & 6 \\
\hline Other & 1 \\
\hline Don't know & 1
\end{tabular}

Q-18. (Filtered. Ask if answered '1' in Q-16) You said that you've been a victim of violence or some criminal act in the past year. Did you report it to any authority?

No

Refused

Don't know 
Q-19. (Filtered. Ask if answered "Yes" in Q-18) To what agency or institution did you report the crime? (Multiple Response) [Do Not Read Responses, Record All That Respondent Mentions, Specify If Other Mentioned] Write Down All Mentioned By Respondent, Code

\begin{tabular}{lc} 
Base: Reported $\mathbf{6 0 2}$ & $\mathbf{( \% )}$ \\
\hline Afghan National Army & 13 \\
Afghan National Police & 37 \\
Shura/ Elders & 18 \\
Local militia (police) & 2 \\
Tribal leader / Malik & 16 \\
Local Commander or Warlord & 4 \\
Mullah Saheb & 8 \\
Local PRT & $*$ \\
Office of UN organization(s) & $*$ \\
Afghanistan Independent Human Rights Commission & 1 \\
District Governor/ Woleswal & 20 \\
Provincial authority & 7 \\
Central Government & 2 \\
Public prosecutor & 2 \\
Courts & 2 \\
Press or other media & $*$ \\
Other & $*$ \\
Don't know & 1
\end{tabular}

Q-20. (Ask if answered "No" in Q-18) Why didn't you report the rime? (Multiple Response) [Do Not Read Responses, Record All That Respondent Mentions, Specify If Other Mentioned] Write Down All Mentioned By Respondent, Code

\begin{tabular}{|c|c|}
\hline Base: Didn't report 339 & $\mathbf{( \% )}$ \\
\hline It makes no difference & 13 \\
\hline Danger or fear of retaliation & 21 \\
\hline Lack of evidence & 9 \\
\hline It wasn't serious & 23 \\
\hline Didn't know where to report it & 10 \\
\hline Lack of trust on government officials & 15 \\
\hline Lack of legal counsel & 3 \\
\hline Don't know & 12
\end{tabular}


Q-21. If you were a victim of violence or any criminal act, how much confidence would you have that the governmental law-enforcing organizations and judicial systems would punish the guilty party? (Read Out Answers)

\begin{tabular}{l|c|}
\hline Base: All respondents $\mathbf{6 4 6 7}$ & $\mathbf{( \% )}$ \\
\hline A great deal of confidence & 16 \\
\hline A fair amount of confidence & 41 \\
\hline Not very much confidence & 24 \\
\hline No confidence at all & 16 \\
\hline Refused & $*$ \\
\hline Don't know & 3
\end{tabular}

Q-22. (Ask all) In your view, what is the biggest cause of crime in Afghanistan? (Open-ended question. Write down answer)

Write Reason:

\begin{tabular}{lc} 
Base: All respondents $\mathbf{6 4 6 7}$ & $\mathbf{( \% )}$ \\
\hline Taliban & 3 \\
Terrorism & 1 \\
Unemployment & 20 \\
\hline Corruption & 19 \\
\hline Drugs & 6 \\
\hline Poverty & 6 \\
\hline Illiteracy & 6 \\
Existence of irresponsible armed groups & 2 \\
Insecurity & 9 \\
\hline Lack of reconstruction & $*$ \\
\hline Lack of Govt. attention/ weak Govt. & 6 \\
\hline Pakistan's interference & 1 \\
\hline Lack of law implementation & 5 \\
Having a weak/low-paid police & $*$ \\
Discriminations & 2 \\
Returnees & $*$ \\
\hline Western countries & $*$ \\
Presence of international forces & 3 \\
Rapes & $*$ \\
Kidnapping children & $*$ \\
Murders & $*$ \\
Robberies & $*$ \\
Powerful people misusing their powers & $*$ \\
Poorly protected borders & $*$ \\
Refused & $*$ \\
Don>t know & 7 \\
\hline
\end{tabular}


Q-23. Please tell me whether you think that corruption is a major problem, a minor problem, or no problem at all in the following areas. (Circle '8' for Refused or '9' for Don't Know, if volunteered.)

\begin{tabular}{|l|c|c|c|c|c|}
\hline Base: All respondents 6467 & $\begin{array}{c}\text { Major } \\
\text { Problem }\end{array}$ & $\begin{array}{c}\text { Minor } \\
\text { Problem }\end{array}$ & $\begin{array}{c}\text { Not a } \\
\text { Problem }\end{array}$ & $\begin{array}{c}\text { Refused } \\
\text { a) }\end{array}$ & $\begin{array}{c}\text { Don't } \\
\text { know }\end{array}$ \\
\hline a) In your daily life & 55 & $\mathbf{( \% )}$ & $\mathbf{( \% )}$ & $\mathbf{( \% )}$ & $\mathbf{( \% )}$ \\
\hline b) In your neighborhood & 50 & 33 & 16 & $*$ & 1 \\
\hline c) In your local authorities & 56 & 33 & 15 & $*$ & 1 \\
\hline d) In your provincial government & 56 & 26 & 7 & $*$ & 2 \\
\hline e) In Afghanistan as a whole & 76 & 17 & 5 & $*$ & 2 \\
\hline
\end{tabular}

Q-24. Compared to a year ago, do you think the amount of corruption overall in ... (Read out options below one by one) has increased, stayed the same or decreased?

\begin{tabular}{l|c|c|c|c|c|}
\hline Base: All respondents $\mathbf{6 4 6 7}$ & Increased & $\begin{array}{c}\text { Stayed the } \\
\text { same }\end{array}$ & $\begin{array}{c}\text { Decreased } \\
\text { Refused }\end{array}$ & $\begin{array}{c}\text { Don't } \\
\text { know }\end{array}$ \\
\hline a) In your daily life & $\mathbf{( \% )}$ & $\mathbf{( \% )}$ & $\mathbf{( \% )}$ & $\mathbf{( \% )}$ & $\mathbf{( \% )}$ \\
\hline b) In your neighborhood & 27 & 48 & 23 & 1 & 2 \\
\hline c) In your local authorities & 24 & 51 & 23 & $*$ & 2 \\
\hline $\begin{array}{l}\text { d) In your provincial } \\
\text { government }\end{array}$ & 44 & 46 & 17 & $*$ & 3 \\
\hline e) In Afghanistan as a whole & 53 & 38 & 13 & $*$ & 3 \\
\hline
\end{tabular}

Q-25. Whenever you have contacted government officials, how often in the past year have you had to give cash, a gift or perform a favor for an official? If you had contacts with such officials in the past year, was it in all cases, most of the cases, in isolated or in no cases? How about your contacts with.... (Rotate items on the list)

\begin{tabular}{|l|c|c|c|c|c|c|c|}
\hline Base: All respondents $\mathbf{6 4 6 7}$ & $\begin{array}{c}\text { In all } \\
\text { cases }\end{array}$ & $\begin{array}{c}\text { Most } \\
\text { cases }\end{array}$ & $\begin{array}{c}\text { Isolated } \\
\text { cases }\end{array}$ & $\begin{array}{c}\text { No } \\
\text { cases }\end{array}$ & $\begin{array}{c}\text { Had no } \\
\text { contacts }\end{array}$ & Ref. & DK \\
\hline $\begin{array}{l}\text { a) } \\
\text { a) }\end{array}$ & $\mathbf{( \% )}$ & $\mathbf{( \% )}$ & $\mathbf{( \% )}$ & $\mathbf{( \% )}$ & $\mathbf{( \% )}$ & $\mathbf{( \% )}$ \\
\hline Municipals in the & 3 & 7 & 12 & 28 & 49 & $*$ & 1 \\
\hline b) Customs office & 3 & 7 & 10 & 27 & 52 & $*$ & 1 \\
\hline c) Afghan National Police & 3 & 10 & 19 & 32 & 36 & $*$ & 1 \\
\hline d) Afghan National Army & 2 & 6 & 9 & 37 & 45 & $*$ & 1 \\
\hline e) Judiciary / courts & 4 & 10 & 15 & 26 & 42 & $*$ & 1 \\
\hline f) State electricity supply & 2 & 7 & 13 & 30 & 46 & 1 & 1 \\
\hline g) Public healthcare service & 3 & 10 & 20 & 34 & 32 & $*$ & 1 \\
\hline h) When applying for a job & 3 & 11 & 16 & 28 & 40 & 1 & 1 \\
\hline
\end{tabular}




\begin{tabular}{|c|c|c|c|c|c|c|}
\hline $\begin{array}{l}\text { i) Admissions to schools/ } \\
\text { university }\end{array}$ & 3 & 8 & 13 & 34 & 41 & $*$ \\
\hline $\begin{array}{l}\text { j) To receive official } \\
\text { documents }\end{array}$ & 5 & 10 & 13 & 28 & 42 & $*$ \\
\hline
\end{tabular}

Q-26. Now I will read you six different activities that you could participate in. Please, tell me, whether you would participate in the following activities with 'no fear', 'some fear' or a 'lot of fear'?

\begin{tabular}{|c|c|c|c|c|c|}
\hline Base: All respondents 6467 & No fear & $\begin{array}{l}\text { Some } \\
\text { fear }\end{array}$ & $\begin{array}{l}\text { A lot of } \\
\text { fear }\end{array}$ & Refused & $\begin{array}{l}\text { Don't } \\
\text { know }\end{array}$ \\
\hline $\begin{array}{l}\text { a) When participating in resolving } \\
\text { problems in your community }\end{array}$ & 51 & 35 & 11 & 1 & 2 \\
\hline b) Voting in a national election & 39 & 39 & 21 & * & 1 \\
\hline $\begin{array}{l}\text { c) Participating in a peaceful } \\
\text { demonstration }\end{array}$ & 29 & 38 & 29 & 2 & 3 \\
\hline d) To run for a public office & 28 & 38 & 26 & 2 & 5 \\
\hline $\begin{array}{l}\text { e) When encountering ANP } \\
\text { officers }\end{array}$ & 45 & 33 & 19 & 1 & 2 \\
\hline $\begin{array}{l}\text { f) When traveling from one part } \\
\text { of Afghanistan to another part of } \\
\text { the country }\end{array}$ & 24 & 42 & 32 & * & 2 \\
\hline
\end{tabular}

Q-27. In comparison to one year ago, do people in the area where you live feel more safe, as safe as before, or less safe to freely express their opinions?

\begin{tabular}{|l|c|}
\hline Base: All respondents $\mathbf{6 4 6 7}$ & $\mathbf{( \% )}$ \\
\hline More safe to express their opinions & 25 \\
\hline As safe as before to express their opinions & 49 \\
\hline Less safe to express their opinions & 17 \\
\hline Refused & 2 \\
\hline Don't know & 7
\end{tabular}

Q28a-b [ASK if Code 1 "more safe" in Q27] What changes compared with the past, or reasons, do you think have made most people to feel safe to express their opinions in the area where you live? (Pre-coded. Do NOT read out. Write down the main answer and code to the list) Q28a. First Mention: Q28b. Second Mention:

Do not print code list and use only in office with coders 
Appendix 3: Interview Questionnaire | 199

\begin{tabular}{|c|c|c|}
\hline \multirow[t]{2}{*}{ Base: More safe 1642} & $\begin{array}{c}\text { Q-28a } \\
1^{\text {st }} \text { mentioned }\end{array}$ & $\begin{array}{l}\text { Q-28a \& b } \\
\text { Cumulative }\end{array}$ \\
\hline & $(\%)$ & $(\%)$ \\
\hline The removal of local militias & 3 & 5 \\
\hline Freedom of speech is guaranteed & 19 & 32 \\
\hline The security conditions are good (in our area) & 46 & 54 \\
\hline Having (working) parliament and local shuras & 1 & 1 \\
\hline Peace and democracy & 5 & 10 \\
\hline Presence of ISAF / Coalition forces & 1 & 2 \\
\hline Presence of CDC & 1 & 1 \\
\hline Presence of PC & * & 1 \\
\hline (Respect for) Human rights & 1 & 1 \\
\hline Disarmament & * & 2 \\
\hline Reconstruction & * & 2 \\
\hline Freedom of press is guaranteed & 2 & 4 \\
\hline Having a legal constitution & 2 & 3 \\
\hline Corruption has decreased & $*$ & 1 \\
\hline More attention to women's rights & * & 1 \\
\hline Good Government & 3 & 6 \\
\hline Better education & 1 & 2 \\
\hline Better Justice system & * & 1 \\
\hline Taliban removal & 2 & 4 \\
\hline People's cooperation with the Gov't & 3 & 7 \\
\hline Having ANP and ANA & 3 & 6 \\
\hline Better economic situation & $*$ & * \\
\hline Refused & * & * \\
\hline Don't know & 6 & 6 \\
\hline
\end{tabular}


Q-29a-b. [ASK if code 3 "less safe" in Q27] Why don't people in your area have the freedom to express their political opinions? (Pre-coded. Do NOT read out. Write down up top answer and code to the list)

Q29a. First Mention:

Q29b. Second Mention:

Do not print code list and use only in office with coders

\begin{tabular}{|l|c|c|}
\hline Base: Less safe $\mathbf{1 0 9 0}$ & $\mathbf{Q - 2 9 A}$ & $\mathbf{Q - 2 9 B}$ \\
\hline Fear for personal safety & $\mathbf{( \% )}$ & $\mathbf{( \% )}$ \\
\hline Women are under the control of men & 27 & 34 \\
\hline Security conditions are bad in this area & 5 & 7 \\
\hline Presence of Taliban in the area & 21 & 25 \\
\hline Presence of warlords & 16 & 24 \\
\hline The Government doesn't allow freedom of political opinions & 4 & 6 \\
\hline No real democracy & 7 & 11 \\
\hline No disarmament & 2 & 3 \\
\hline Fear from Coalition/foreign forces & $*$ & $*$ \\
\hline Ethnic discrimination & 1 & 2 \\
\hline Elders / Mullahs don't allow freedom of opinions & 1 & 2 \\
\hline Lack of awareness of legal rights & 1 & 1 \\
\hline Not interested in/Lack of information about politics & 1 & 1 \\
\hline The Government doesn't care about people's opinion & 1 & 1 \\
\hline Existence of smugglers & 3 & 7 \\
\hline Lack of education & $*$ & 1 \\
\hline Fear from police & 1 & 3 \\
\hline Fear from Malik & $*$ & 1 \\
\hline Corruption & $*$ & 1 \\
\hline Refused & $*$ & $*$ \\
\hline Don't Know & 8 & 8 \\
\hline
\end{tabular}

Q-30. (Ask all) How much influence do you think someone like you can have over government decisions - a lot, some, very little, or none at all?

\begin{tabular}{lc} 
Base: All respondents $\mathbf{6 4 6 7}$ & $\mathbf{( \% )}$ \\
\hline A lot & 12 \\
\hline Some & 42 \\
Very little & 19 \\
\hline None at all & 24 \\
Refused & $*$ \\
\hline Don't know & 3
\end{tabular}


Q-31. In general how satisfied or dissatisfied you are with your MP representing you in the Parliament?

\begin{tabular}{|l|c|}
\multicolumn{1}{|c}{ Base: All respondents $\mathbf{6 4 6 7}$} & $\mathbf{( \% )}$ \\
\hline Very satisfied & 18 \\
\hline Somewhat satisfied & 46 \\
Somewhat dissatisfied & 20 \\
Very dissatisfied & 13 \\
Refused & $*$ \\
\hline Don't know & 2 \\
\hline
\end{tabular}

Q-32. Now tell me in your opinion how much useful the parliament is in general?

\begin{tabular}{|l|c|}
\hline \multicolumn{1}{|c|}{ Base: All respondents $\mathbf{6 4 6 7}$} & $\mathbf{( \% )}$ \\
\hline A lot & 30 \\
\hline Some & 37 \\
\hline Very little & 19 \\
\hline None at all & 12 \\
\hline Refused & $*$ \\
\hline Don't know & 2 \\
\hline
\end{tabular}

Q-33a-e.Do you think the following institutions consider the Afghan Public interests, their own interests or more or less both when making decisions and policies?

\begin{tabular}{|c|c|c|c|c|c|c|}
\hline rest & $\begin{array}{l}\text { 3ase: All } \\
\text { ndents } 6467\end{array}$ & $\begin{array}{l}\text { Afghans } \\
\text { interests }\end{array}$ & $\begin{array}{c}\text { Their } \\
\text { own } \\
\text { interests }\end{array}$ & $\begin{array}{c}\text { Both } \\
\text { more or } \\
\text { less }\end{array}$ & Refused & $\begin{array}{l}\text { Don't } \\
\text { Know }\end{array}$ \\
\hline & & $(\%)$ & $(\%)$ & $(\%)$ & $(\%)$ & $(\%)$ \\
\hline $33 \mathrm{~A}$ & Government & 46 & 30 & 22 & * & 2 \\
\hline $33 \mathrm{~B}$ & Court & 26 & 49 & 23 & * & 2 \\
\hline $33 \mathrm{C}$ & Parliament & 27 & 44 & 27 & * & 3 \\
\hline $33 \mathrm{D}$ & NGOs & 19 & 53 & 25 & * & 4 \\
\hline $33 \mathrm{E}$ & Donors & 17 & 50 & 26 & 1 & 7 \\
\hline
\end{tabular}


Q-34. (ASK ALL) I would like to ask you about some officials, institutions and organizations in our country. I will read these out to you. As I read out each, please tell me how much confidence you have in each of the institutions and organizations and officials to perform their jobs. Do you have a great deal of confidence, a fair amount of confidence, not very much confidence, or no confidence at all in?

\begin{tabular}{|c|c|c|c|c|c|c|}
\hline $\begin{array}{l}\text { Base: All } \\
\text { respondents } \\
6467\end{array}$ & $\begin{array}{c}\text { A great } \\
\text { deal of } \\
\text { confidence }\end{array}$ & $\begin{array}{c}\text { A fair } \\
\text { amount of } \\
\text { confidence }\end{array}$ & $\begin{array}{l}\text { Not very } \\
\text { much } \\
\text { confidence }\end{array}$ & $\begin{array}{c}\text { No } \\
\text { confidence } \\
\text { at all } \\
(\%)\end{array}$ & Refused & $\begin{array}{l}\text { Don't } \\
\text { Know }\end{array}$ \\
\hline a) A forhan & & & & & & \\
\hline National Army & 59 & 32 & 6 & 2 & & 1 \\
\hline $\begin{array}{l}\text { b) Afghan } \\
\text { National Police }\end{array}$ & 41 & 38 & 15 & 6 & $*$ & $*$ \\
\hline $\begin{array}{l}\text { c) Political } \\
\text { parties }\end{array}$ & 11 & 32 & 33 & 21 & $*$ & 3 \\
\hline $\begin{array}{l}\text { d) The } \\
\text { Government } \\
\text { Justice system }\end{array}$ & 11 & 38 & 33 & 17 & $*$ & 2 \\
\hline $\begin{array}{l}\text { e) Government } \\
\text { Ministers }\end{array}$ & 15 & 39 & 29 & 15 & * & 2 \\
\hline $\begin{array}{l}\text { f) Independent } \\
\text { Election } \\
\text { commission }\end{array}$ & 18 & 36 & 27 & 17 & $*$ & 2 \\
\hline $\begin{array}{l}\text { g) Public } \\
\text { administration }\end{array}$ & 14 & 42 & 29 & 12 & $*$ & 3 \\
\hline $\begin{array}{l}\text { h) the } \\
\text { Municipality }\end{array}$ & 12 & 34 & 30 & 19 & * & 5 \\
\hline i) Local militias & 9 & 24 & 26 & 36 & 1 & 3 \\
\hline $\begin{array}{l}\text { j) Community } \\
\text { Development } \\
\text { Councils }\end{array}$ & 18 & 43 & 25 & 11 & $*$ & 2 \\
\hline $\begin{array}{l}\text { k) Provincial } \\
\text { Councils }\end{array}$ & 19 & 43 & 24 & 11 & * & 3 \\
\hline l) Parliament & 19 & 40 & 25 & 13 & $*$ & 3 \\
\hline $\begin{array}{l}\text { l) Community } \\
\text { Shuras/ Jirgas }\end{array}$ & 24 & 42 & 22 & 10 & * & 3 \\
\hline $\begin{array}{l}\text { m) National } \\
\text { NGOs }\end{array}$ & 16 & 39 & 29 & 13 & * & 3 \\
\hline $\begin{array}{l}\text { n) International } \\
\text { NGOs }\end{array}$ & 17 & 37 & 27 & 15 & $*$ & 3 \\
\hline $\begin{array}{l}\text { o) Electronic } \\
\text { media such as } \\
\text { radio, TV }\end{array}$ & 33 & 37 & 19 & 8 & $*$ & 2 \\
\hline $\begin{array}{l}\text { p) Newspapers, } \\
\text { print media }\end{array}$ & 21 & 36 & 23 & 13 & 1 & 6 \\
\hline
\end{tabular}


Q-35. I'm going to read some statements to you about ANA. Please tell me if you agree with each. (Read out statement, wait for response and then ask): Strongly or somewhat?

\begin{tabular}{|c|c|c|c|c|c|c|}
\hline \multirow{2}{*}{$\begin{array}{l}\text { Base: All respondents } \\
6467\end{array}$} & $\begin{array}{c}\text { Strongly } \\
\text { agree }\end{array}$ & $\begin{array}{c}\text { Agree } \\
\text { somewhat }\end{array}$ & $\begin{array}{l}\text { Disagree } \\
\text { somewhat }\end{array}$ & $\begin{array}{l}\text { Strongly } \\
\text { disagree }\end{array}$ & Refused & DK \\
\hline & $(\%)$ & $(\%)$ & $(\%)$ & $(\%)$ & $(\%)$ & $(\%)$ \\
\hline $\begin{array}{l}\text { a) ANA is honest and } \\
\text { fair with the Afghan } \\
\text { people. }\end{array}$ & 58 & 34 & 6 & 2 & $*$ & 1 \\
\hline $\begin{array}{l}\text { b) ANA is } \\
\text { unprofessional and } \\
\text { poorly trained. }\end{array}$ & 18 & 33 & 30 & 17 & $*$ & 2 \\
\hline $\begin{array}{l}\text { c) ANA needs the } \\
\text { support of foreign } \\
\text { troops and cannot } \\
\text { operate by itself. }\end{array}$ & 30 & 40 & 21 & 8 & $*$ & 2 \\
\hline $\begin{array}{l}\text { d) ANA helps } \\
\text { improve the security }\end{array}$ & 53 & 33 & 10 & 3 & * & 1 \\
\hline
\end{tabular}

Q-36. I'm going to read some statements to you about ANP. Please tell me if you agree with each. (Read out statement, wait for response and then ask): Strongly or somewhat?

\begin{tabular}{|c|c|c|c|c|c|c|}
\hline \multirow{2}{*}{$\begin{array}{l}\text { Base: All respondents } \\
6467\end{array}$} & $\begin{array}{l}\text { Strongly } \\
\text { agree }\end{array}$ & $\begin{array}{c}\text { Agree } \\
\text { somewhat }\end{array}$ & $\begin{array}{l}\text { Disagree } \\
\text { somewhat }\end{array}$ & $\begin{array}{l}\text { Strongly } \\
\text { disagree }\end{array}$ & Refused & DK \\
\hline & $(\%)$ & $(\%)$ & $(\%)$ & $(\%)$ & $(\%)$ & $(\%)$ \\
\hline $\begin{array}{l}\text { a) ANP is honest and } \\
\text { fair with the Afghan } \\
\text { people. }\end{array}$ & 44 & 40 & 12 & 4 & * & 1 \\
\hline $\begin{array}{l}\text { b) ANP is } \\
\text { unprofessional and } \\
\text { poorly trained. }\end{array}$ & 20 & 38 & 29 & 11 & * & 1 \\
\hline $\begin{array}{l}\text { c) ANP needs the } \\
\text { support of foreign } \\
\text { troops and cannot } \\
\text { operate by itself. }\end{array}$ & 28 & 41 & 21 & 8 & * & 2 \\
\hline $\begin{array}{l}\text { d) ANP helps improve } \\
\text { the security }\end{array}$ & 37 & 40 & 15 & 6 & * & 1 \\
\hline $\begin{array}{l}\text { e) ANP is efficient at } \\
\text { arresting those who } \\
\text { have committed crimes } \\
\text { so that they can be } \\
\text { brought to justice }\end{array}$ & 30 & 40 & 21 & 8 & * & 2 \\
\hline
\end{tabular}


Q-37a. Thinking of the National Government, how do you feel about the way it is carrying out its responsibilities? Is it doing a very good job, somewhat good job, somewhat bad job or a very bad job?

\begin{tabular}{|l|c|}
\hline Base: All respondents $\mathbf{6 4 6 7}$ & $\mathbf{( \% )}$ \\
\hline Very good job & 17 \\
\hline Somewhat good job & 56 \\
\hline Somewhat bad job & 20 \\
\hline Very bad job & 5 \\
\hline Refused & $*$ \\
\hline Don't know & 2 \\
\hline
\end{tabular}

Q-37b. And speaking of particular aspects of its work, do you think the National Government is doing a very good job, somewhat good job, somewhat bad job or a very bad job in the following fields? (Ask for each on the list)

\begin{tabular}{|c|c|c|c|c|c|c|}
\hline \multirow{2}{*}{$\begin{array}{l}\text { Base: All } \\
\text { respondents } \\
6467\end{array}$} & $\begin{array}{l}\text { Very Good } \\
\text { Job }\end{array}$ & $\begin{array}{c}\text { Somewhat } \\
\text { good job }\end{array}$ & $\begin{array}{l}\text { Somewhat } \\
\text { bad job }\end{array}$ & $\begin{array}{c}\text { Very bad } \\
\text { job }\end{array}$ & Refused & $\begin{array}{l}\text { Don't } \\
\text { Know }\end{array}$ \\
\hline & $(\%)$ & $(\%)$ & $(\%)$ & $(\%)$ & $(\%)$ & $(\%)$ \\
\hline a) Education & 38 & 47 & 12 & 3 & & 1 \\
\hline $\begin{array}{l}\text { b) Healthcare } \\
\text { system }\end{array}$ & 16 & 47 & 28 & 8 & & 1 \\
\hline $\begin{array}{l}\text { c) Creating job } \\
\text { opportunities }\end{array}$ & 7 & 26 & 36 & 31 & * & 1 \\
\hline $\begin{array}{l}\text { d) Maintaining } \\
\text { relations with } \\
\text { neighboring } \\
\text { countries }\end{array}$ & 15 & 42 & 27 & 12 & * & 2 \\
\hline $\begin{array}{l}\text { e) Reviving/ } \\
\text { Developing the } \\
\text { economy }\end{array}$ & 9 & 34 & 35 & 21 & * & 1 \\
\hline $\begin{array}{l}\text { f) Fighting } \\
\text { corruption }\end{array}$ & 7 & 22 & 33 & 36 & * & 1 \\
\hline g) Security & 22 & 40 & 23 & 15 & * & 1 \\
\hline
\end{tabular}


Q-38. Turning to elements of the local government, do you think that overall it is doing a very good job, somewhat good job, somewhat bad job or a very bad job?

Base: All
respondents 6467
a) Provincial
Government
b) Municipal
authorities
(urban residents only
1390)
c) Local authorities
(rural residents only
5076)

\begin{tabular}{|c|c|c|c|c|c|}
\hline $\begin{array}{c}\text { A Very Good } \\
\text { Job }\end{array}$ & $\begin{array}{c}\text { Somewhat } \\
\text { good job }\end{array}$ & $\begin{array}{c}\text { Somewhat } \\
\text { Bad Job }\end{array}$ & $\begin{array}{c}\text { A Very } \\
\text { Bad Job }\end{array}$ & Refused & DK \\
\hline $\mathbf{( \% )}$ & $\mathbf{( \% )}$ & $\mathbf{( \% )}$ & $\mathbf{( \% )}$ & $\mathbf{( \% )}$ & $\mathbf{( \% )}$ \\
\hline 23 & 55 & 15 & 4 & $*$ & 3 \\
\hline 12 & 42 & 26 & 14 & $*$ & 7 \\
\hline
\end{tabular}

Q-39 a-b. What in your opinion is the most important achievement of the central government in the past two years? And what is next? (Open-ended. Write down first two mentions]

a)

98. Refused 99. Don't Know

b)

98. Refused 99. Don't Know

\begin{tabular}{|l|c|c|}
\hline Base: All respondents & $\begin{array}{c}\text { Q-39a } \\
\mathbf{1}^{\text {st }}\end{array}$ & $\begin{array}{c}\text { Q-39 a \& b } \\
\text { (cumulative }\end{array}$ \\
\hline No achievements & $\mathbf{( \% )}$ & $\mathbf{( \% )}$ \\
\hline Establishing peace and security & 3 & 3 \\
\hline Better education system & 15 & 24 \\
\hline Reconstruction & 15 & 27 \\
\hline Elections & 13 & 24 \\
\hline Improving communication system & 3 & 6 \\
\hline Attracting foreign aid & 1 & 1 \\
\hline Having a good relationship with foreign countries & 2 & 3 \\
\hline Having ANP and ANA & 2 & 3 \\
\hline Improving economy & 6 & 11 \\
\hline Improving healthcare system & 2 & 6 \\
\hline Improving media & 1 & 4 \\
\hline Having Parliament & $*$ & $*$ \\
\hline Freedom of speech & 2 & 4 \\
\hline Having a strong government & 2 & 4 \\
\hline Creating job opportunities & 3 & 5 \\
\hline Removing poppy cultivation & 1 & 3 \\
\hline Disarmament & 2 & 4 \\
\hline
\end{tabular}




\begin{tabular}{|c|c|}
\hline Removing the Taliban and Al-Qaeda & 2 \\
\hline Observing women/human rights & 1 \\
\hline Removing administrative corruption & 1 \\
\hline Creating Development Councils & * \\
\hline Building circle roads & 6 \\
\hline Establishing Constitution & 2 \\
\hline Returnees & * \\
\hline National unity & 1 \\
\hline Improving agriculture & * \\
\hline Paying attention to Islamic values & * \\
\hline Supplying water and power & 2 \\
\hline Using natural resources & * \\
\hline Establishing private sectors & * \\
\hline Improving carpet exports & * \\
\hline Improving business & * \\
\hline Sports & * \\
\hline Transportation system & * \\
\hline Preventing Pakistan and foreign countries interference & * \\
\hline Building Factories & * \\
\hline Democracy & * \\
\hline Building entertainment parks & * \\
\hline Refused & * \\
\hline Don $>$ t know & 8 \\
\hline
\end{tabular}

Q-40a-b. And what in your opinion is the most important failing of the central government in the past two years? And what is next? (Open-ended. Write down first two mentions]

a)

\section{Refused 99. Don't Know}

b)

98. Refused 99. Don't Know

\begin{tabular}{|l|c|c|}
\hline Base: All respondents $\mathbf{6 4 6 7}$ & $\begin{array}{c}\text { Q-40a } \\
\mathbf{1}^{\text {st }} \\
\text { mentioned }\end{array}$ & $\begin{array}{c}\text { Q-40 a \& b } \\
\text { Cumulative }\end{array}$ \\
\hline No failures & $\mathbf{( \% )}$ & $\mathbf{( \% )}$ \\
\hline Insecurity & $*$ & $*$ \\
\hline Bad education system & 21 & 30 \\
\hline No/ lack of reconstruction/roads/bridges & 3 & 5 \\
\hline Holding unfair elections & 2 & 3 \\
\hline Lack of foreign assistance & $*$ & 1 \\
\hline Lack of/no relations with foreign countries & $*$ & 1 \\
\hline Weak ANA and ANP & $*$ & 1 \\
\hline Weak economy & 1 & 1 \\
\hline Lack of healthcare centers & 4 & 9 \\
\hline
\end{tabular}




\begin{tabular}{|c|c|c|}
\hline Weak Parliament & * & 1 \\
\hline Lack of freedom of speech & * & 1 \\
\hline Weak Government & 6 & 10 \\
\hline Lack of job opportunities & 7 & 17 \\
\hline Administrative corruption & 22 & 37 \\
\hline Fulfilling it's commitments & 1 & 1 \\
\hline Removing the Terrorism & 1 & 2 \\
\hline Removing the Taliban & 6 & 9 \\
\hline Removing drugs & 3 & 6 \\
\hline Preventing civilian casualties & 1 & 1 \\
\hline National unity & 1 & 1 \\
\hline Returnees & $*$ & * \\
\hline Disarmament & $*$ & 1 \\
\hline Observing Islamic rules & $*$ & 1 \\
\hline Injustice & 1 & 3 \\
\hline Human rights & * & * \\
\hline Keeping safe historical heritage & * & * \\
\hline Foreign forces in the country (long time) & 1 & 3 \\
\hline Shelter & * & * \\
\hline Kidnappings & * & 1 \\
\hline Water and power & 1 & 2 \\
\hline Preventing Pakistan and foreign countries interference & 1 & 3 \\
\hline Lack of unity among tribes & 2 & 4 \\
\hline High prices & * & 1 \\
\hline Suicide attacks & 2 & 4 \\
\hline People referring to Christianity & * & $*$ \\
\hline Factories & * & $*$ \\
\hline Lack of attention to agriculture & $*$ & * \\
\hline Lack of transparency in the government affaires & * & * \\
\hline $\begin{array}{l}\text { Creating Arbaki forces (Armed groups supported by the } \\
\text { government) }\end{array}$ & $*$ & $*$ \\
\hline Not having good municipalities & & * \\
\hline Refused & * & * \\
\hline Don't know & 8 & 8 \\
\hline
\end{tabular}

Q-41a-c. I'm going to read some ideas. Please tell me if you agree with each. (Read out statement, wait for response and then ask): Strongly or somewhat?

\begin{tabular}{|l|c|c|c|c|c|c|}
\hline Base: All respondents $\mathbf{6 4 6 7}$ & $\begin{array}{c}\text { Strongly } \\
\text { agree }\end{array}$ & $\begin{array}{c}\text { Agree } \\
\text { somewhat }\end{array}$ & $\begin{array}{c}\text { Disagree } \\
\text { somewhat }\end{array}$ & $\begin{array}{c}\text { Strongly } \\
\text { disagree }\end{array}$ & Refused & DK \\
\hline $\begin{array}{l}\text { a) It is a good thing that } \\
\text { the government should allow }\end{array}$ & 39 & 44 & $\mathbf{( \% )}$ & $\mathbf{( \% )}$ & $\mathbf{( \% )}$ & $\mathbf{( \% )}$ \\
\hline \begin{tabular}{l} 
peaceful opposition \\
\hline
\end{tabular} & & & 13 & 2 & $*$ & 2 \\
\hline
\end{tabular}


b) Everyone should have equal rights under the law, regardless of their gender, ethnicity or religion

c) A person should vote the way his or her community votes, not how they feel individually

49

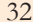

14

22

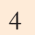

19

We are going to change the topic. "Reconciliation" refers to a process where opposing parties explore and overcome the grievance brought on during the conflict and find ways to build trust and live cooperatively with each other. "Reintegration" refers to a process when armed opposition are removed from fighting context and incorporated into a peaceful civilian life.

Q-42. Do you strongly agree, agree somewhat, disagree somewhat or strongly disagree with the Government's reconciliation efforts and negotiations with the armed opposition?

\begin{tabular}{l|c|}
\hline Base: All respondents $\mathbf{6 4 6 7}$ & $\mathbf{( \% )}$ \\
\hline Strongly agree & 42 \\
\hline Agree somewhat & 41 \\
\hline Disagree somewhat & 11 \\
\hline Strongly disagree & 5 \\
\hline Refused & $*$ \\
\hline Don't know & 1
\end{tabular}

Q-43. Do you think the Afghan Government's reconciliation efforts and negotiations will help stabilize the country?

\begin{tabular}{|l|c|}
\hline Base: All respondents $\mathbf{6 4 6 7}$ & $\mathbf{( \% )}$ \\
\hline Yes & 73 \\
No & 23 \\
Refused & $*$ \\
\hline Don't know & 4
\end{tabular}

Q-44. Do you strongly agree, agree somewhat, disagree somewhat or strongly disagree those Anti-Government elements who lay arms and express willingness to reintegrate into society to be provided government assistance, jobs and housing?

Base: All respondents 6467

Strongly agree

Agree somewhat

Disagree somewhat

Strongly disagree

Refused

Don't know 
Q-45a. Thinking about the reasons the armed opposition used violence during the past year, would you say that you in general have a lot of sympathy, a little sympathy, or no sympathy at all for these armed opposition groups?

\begin{tabular}{|l|c|}
\hline Base: All respondents $\mathbf{6 4 6 7}$ & $\mathbf{( \% )}$ \\
\hline A lot of sympathy & 14 \\
\hline A little sympathy & 26 \\
\hline No sympathy at all & 55 \\
\hline Refused & 1 \\
\hline Don't know & 3 \\
\hline
\end{tabular}

Q-45b. You said that you have (repeat response in Q.45) for the armed opposition groups. Why do you say that? Open end; Refused, Don't know

\begin{tabular}{|c|c|c|c|}
\hline \multirow[t]{2}{*}{ Base: All respondents 6467} & $\begin{array}{c}\text { A lot } \\
\text { sympathy } \\
\text { Base: } 933\end{array}$ & $\begin{array}{c}\text { Little } \\
\text { sympathy } \\
\text { Base: } 1651\end{array}$ & $\begin{array}{l}\text { No sympathy } \\
\text { Base: } 3584\end{array}$ \\
\hline & $(\%)$ & $(\%)$ & $(\%)$ \\
\hline Don't want peace and security & 6 & 9 & 15 \\
\hline Earn money through Islamic ways & 1 & 1 & 1 \\
\hline Killing innocent people & 5 & 3 & 15 \\
\hline They are infidels & 1 & 1 & 3 \\
\hline They are Muslim & 23 & 20 & 2 \\
\hline Want to create disunity & $*$ & 1 & 1 \\
\hline They are against the government & 6 & 6 & 14 \\
\hline They are Afghans & 26 & 25 & 2 \\
\hline They are oppressors & 4 & 4 & 21 \\
\hline They are made to do so & $*$ & 1 & $*$ \\
\hline They are robbers & * & * & * \\
\hline They are not Afghans & * & 1 & 2 \\
\hline Destroying roads an bridges & * & $*$ & 1 \\
\hline $\begin{array}{l}\text { The government mistreats the } \\
\text { people }\end{array}$ & 1 & * & * \\
\hline Don't have any sympathy & & 4 & 4 \\
\hline People want peace & 4 & 2 & $*$ \\
\hline They want to fight a holy war (Jihad) & 2 & 1 & * \\
\hline (Just) Have a lot of sympathy & 1 & & \\
\hline Refused & * & * & * \\
\hline Don't know & 18 & 20 & 18 \\
\hline
\end{tabular}


Q-46. Are you aware of the upcoming parliamentary elections in Afghanistan?

Base: All respondents 6467

Yes

No

Refused

*

Don't know

Q-47. (Filtered. Ask if answered "Yes" in Q-46) What is your main source of information about the parliamentary elections? [Do Not Read Out Answers]

Write Answer:

Base: Aware of the upcoming parliamentary election 5072

TV

Radio

Newspapers

Village chief/community leaders

School teacher

Religious leader

Friends and family and neighbors

Pamphlet

Other government office

Non-governmental organization

Other

Don't know

Q-48. How likely are you to vote in the coming parliamentary election?

Base: All respondents 6467

1) Very likely

2) Somewhat likely

3) Somewhat unlikely

4) Very unlikely

8) Refused

9) Don't know 
Q-49. (Filtered. Ask if answered Somewhat Unlikely or Very Unlikely, answers "3 or 4" in Q-48) You said it is somewhat or very unlikely that you would vote in the upcoming elections. Why do you say that? (Single Response only. Ask for most important reason. Do NOT read options) [RECORD ANSWER: CODE POST FIELDWORK]

Base: Somewhat or very unlikely 1502

Don't support any candidate / party

Not interested

Personal reasons: too old, sick, etc.

Elections wouldn't make difference / disillusioned

Fear of intimidation

Insecurity

Do not understand politics

Will not be permitted to vote / women not allowed to vote

Don't have registration card/Don't know how to register

Don't know

Q-50. (Filtered. Ask if answered "Somewhat Likely" or "Very Likely", Codes "1" or "2" in Q-48 What is the most important reason why you want to vote? (Single Response only. Ask for most important reason. Do NOT read options) [RECORD ANSWER: CODE POST FIELDWORK]

Base: Somewhat or very likely 4833

To choose my leaders

It is my right

To bring peace

It will help the country

To bring prosperity / reconstruction

It is my obligation as a citizen to vote

I want to express my views

New government will be established

Strong government

Other

Refused

Don't know 
Q-51. Lets focus on the most recent presidential election. When people talk about elections, they often describe them as free and fair. By "free" they generally mean that all people had the chance to vote as they wished. By "fair" they generally mean that all candidates/parties followed the rules and were given equal access to the public and votes were counted correctly and not manipulated. Thinking about what is meant by "free" and "fair": Do you think the past presidential election was free and fair?

\begin{tabular}{|l|r|}
\hline Base: All respondents $\mathbf{6 4 6 7}$ & $\mathbf{( \% )}$ \\
\hline Was free and fair & $\mathbf{5 4}$ \\
\hline Was NOT free and fair & 38 \\
\hline Refused & 1 \\
\hline Don't know & 7
\end{tabular}

Q-52. (Filtered. Ask if answered "was Not free and fair" in Q-51). You said that you think that the election was not free and fair. What makes you think so? (OPEN RESPONSE, Write down response and then code after field) WRITE ESPONSE:

Base: Election was not fair and free 2457

Buying of votes

Cheating in the vote count

Husbands not letting wives vote

Men voted on behalf of women

Intimidation against voters or party activists

Finding out for whom people voted without their saying

Fraud in the election in general

Delay in the election results

Foreign interference

Other

Refused

Don't know

$\%)$
54
1
7


Q-54. How confident are you that the Afghan Government on its own will be able to conduct elections?

\begin{tabular}{lr|}
\hline Base: All respondents $\mathbf{6 4 6 7}$ & $\mathbf{( \% )}$ \\
\hline A great deal of confidence & 24 \\
\hline A fair amount of confidence & 42 \\
Not very much confidence & 17 \\
No confidence at all & 14 \\
Refused & $*$ \\
Don't know & 3
\end{tabular}

Q-55. Should the international community be involved with the elections?

\begin{tabular}{|l|c|}
\hline Base: All respondents $\mathbf{6 4 6 7}$ & $\mathbf{( \% )}$ \\
\hline Yes & 56 \\
\hline No & 37 \\
\hline Refused & $*$ \\
\hline Don't know & 6
\end{tabular}

Q-56. Now, to change the subject. Sometimes people and communities have problems, related to an issue that concerns everybody in their area, that they can't resolve on their own and so they have to ask for the help of a government or a non-government person, group or agency. In the past 1 year, has your community had such a problem in your area that you had to ask for help or cooperation to resolve it?

Base: All respondents 6467

Yes

No

Refused

Don't know

Q-57. (Filtered. Ask if answered 'Yes' in Q-56): What kind of problem was/is that? (Open-ended. Write down first mentioned answer)
94. Not asked
98. Refused (vol.)
99. Don't Know (vol.)

Base: Contact Govt. or non Govt. person 1396

Lack of water and electricity

Dispute over land

Building mosque

Reconstruction of roads and bridges

Building clinics

Building schools and kindergartens

Robbery and burglary 


\begin{tabular}{l|l}
\hline Poor transportation system & 1 \\
\hline Economic problems & 4 \\
\hline Unemployment & 1 \\
\hline Tribal problems & 5 \\
\hline Presence of Taliban & 1 \\
\hline Security problems & 8 \\
\hline Agricultural problems & 1 \\
\hline Murder & 2 \\
\hline Disarmament & $*$ \\
\hline Lack of shelter & 1 \\
\hline Lack of women rights & 1 \\
\hline Business problems & 1 \\
\hline Foreign forces searching houses & 1 \\
\hline Environmental problems & 3 \\
\hline Family problems & 4 \\
\hline Problems related to Government agencies & 1 \\
\hline Moral problems & 1 \\
\hline Building shops & 2 \\
Refused & $*$ \\
\hline Don't Know & 13 \\
\hline
\end{tabular}

Q-58a-c. (Filtered. Ask if answered 'Yes' in Q-56): Who did you approach/ask to solve the problem? (Up to Three Responses) [Do Not Read List, Write Answer Then Code Response]

Q58a. First Response:

Q58b. Second Response:

Q58c. Third Response:

\begin{tabular}{|l|c|}
\hline Base: Contacted Govt. or non Govt. person $\mathbf{1 3 9 6}$ & $\begin{array}{c}\text { Cumulative (a-c) } \\
\text { (\%) }\end{array}$ \\
\hline Elders of the local shura/jirga & 42 \\
\hline A Member of Parliament & 10 \\
\hline Government agency/office & 11 \\
\hline Afghan National Army & 12 \\
\hline Afghan National Police & 25 \\
Malik / Khan & 27 \\
Provincial governor/ authorities & 18 \\
\hline Community Development Council & 15 \\
\hline District authorities & 31 \\
PRT & 3 \\
NGO & 4 \\
Human Rights Commission & 2 \\
Foreign forces & 2 \\
Mullah & 18
\end{tabular}




\begin{tabular}{ll} 
Municipality & $*$ \\
Friends and family & 1 \\
\hline Taliban & 1 \\
Other & 1 \\
Don't know & 6
\end{tabular}

Q-59. (Filtered. Ask if contacted Government agency/office, answer '3' in Q-58): You said you contacted a government agency/office to resolve your problem. Which government agency/office is that? (Open-ended. Write down first mentioned answer)
94. Not asked
98. Refused
99. Don't Know

Base: Contacted Govt. agency/office 148

District Governor

Directors in MRRD

Courts

Ministry of Public Health

Ministry of Education

Municipality

Directorate of Water and Power

Local Shuras

Foreign forces

Don't know

Q-60 (Filtered is ' 1 ' VILLAGE, NEIGHBORHOOD BASED SHURA/JIRGA in Q-58) What made you decide to take your dispute to the Shura/Jirga vs State Court? (Open ended question, write down reason.)

Write reason:

98. Refused 99. Don't Know

\begin{tabular}{|c|c|}
\hline Base: Contacted village/neighborhood Shura/Jirga 582 & $(\%)$ \\
\hline Because local Shuras are honest & 35 \\
\hline Are not related to the courts & 5 \\
\hline Security problems & 3 \\
\hline Land dispute & 1 \\
\hline Corruption in government courts & 15 \\
\hline Resolve disputes efficiently & 10 \\
\hline Decisions of Shuras are based on Islamic laws & 1 \\
\hline Local elders are members of the Shura & 3 \\
\hline No government courts in the area & 1 \\
\hline Refused & 1 \\
\hline Don’t know & 27 \\
\hline
\end{tabular}

Q-61. (Filtered. Ask if answered 'Yes' to Q-56: Has this problem been resolved or it's still pending resolution? 
Base: Contacted Govt. or non Govt. person 1396

Resolved

Pending resolution

Refused

Don't know

Q-62. (Filtered is ' 1 ' Resolved in Q-61) How long did it take to resolve?

\begin{tabular}{|lc} 
Base: Resolved 779 & $(\mathbf{0 )}$ \\
\hline One day & 6 \\
\hline One week & 27 \\
One month & 31 \\
\hline More than three months & 15 \\
\hline More than six months & 12 \\
\hline More than one year & 8 \\
\hline Don't know & 2
\end{tabular}

Q-63. How satisfied you are with the available disputes resolution mechanisms/ services in your area?

\begin{tabular}{|l|c|}
\hline Base: All respondents $\mathbf{6 4 6 7}$ & $\mathbf{( \% )}$ \\
\hline Very satisfied & 21 \\
\hline Somewhat satisfied & 49 \\
\hline Somewhat not satisfied & 19 \\
\hline Not satisfied & 7 \\
\hline Refused & $*$ \\
\hline Don't know & 4
\end{tabular}

Q-64. (ASK ALL) Tell me, do you strongly agree, agree somewhat, disagree somewhat, or strongly disagree with the following statements about State Courts?

\section{Base: All respondents 6467}

a) State Courts are accessible to me

b) State Courts are fair and trusted

c) State Courts are not corrupt compared to other options of settling a dispute (informal systems such as local jirgas \& shuras)

d) State Courts follow the local norms and values of our people

e) State Courts are effective at delivering justice

f) State Courts resolve cases timely and promptly

\begin{tabular}{|c|c|c|c|c|c|}
\hline StA & ASw & DSw & StD & Ref & DK \\
\hline $\mathbf{( \% )}$ & $(\mathbf{\%})$ & $\mathbf{( \% )}$ & $\mathbf{( \% )}$ & $\mathbf{( \% )}$ & $\mathbf{( \% )}$ \\
\hline 28 & 45 & 18 & 8 & $*$ & 1 \\
\hline 13 & 40 & 31 & 13 & $*$ & 2 \\
\hline 12 & 37 & 33 & 15 & $*$ & 3 \\
\hline 13 & 38 & 32 & 14 & $*$ & 2 \\
\hline 16 & 38 & 29 & 15 & $*$ & 3 \\
\hline 11 & 31 & 32 & 23 & $*$ & 2 \\
\hline
\end{tabular}


Q-65. And now let's turn to village/neighborhood based Jirgas/ Shura, Tell me do you strongly agree, agree somewhat, disagree somewhat, or strongly disagree with the following statements about the village/neighborhood based Jirgas / Shuras?

\section{Base: All respondents 6467}

a) Local jirgas, shuras are accessible to me

b) Local jirgas, shuras are fair and trusted

c) Local jirgas, shuras follow the local norms and values of our people

d) Local jirgas, shuras are effective at delivering justice

e) Local jirgas, shuras resolve cases timely and promptly

\begin{tabular}{|c|c|c|c|c|c|}
\hline StA & ASw & DSw & StD & REF & DK \\
\hline $\mathbf{( \% )}$ & $\mathbf{( \% )}$ & $\mathbf{( \% )}$ & $\mathbf{( \% )}$ & $\mathbf{( \% )}$ & $\mathbf{( \% )}$ \\
\hline 43 & 43 & 9 & 4 & $*$ & 1 \\
\hline 27 & 46 & 21 & 5 & $*$ & 1 \\
\hline 27 & 43 & 23 & 6 & $*$ & 2 \\
\hline 26 & 43 & 22 & 7 & $*$ & 2 \\
\hline 28 & 38 & 23 & 8 & $*$ & 2 \\
\hline
\end{tabular}

Q-66. (ASK ALL) Now let's talk specifically about women related issues. What is the biggest problem facing women in this area today? (Code in the first column of the table below) [Do Not Read Code List]

(a) Write Answer:

\section{Base: All respondents 6467}

Lack of rights / women's rights

Can't leave homes

Under control of men / men have power

Education / illiteracy

General health care

Pregnancy related health care

Forced marriages/ dowry

Domestic violence

Poverty

Security

Representation in Shura/ Jirga

Lack of job opportunities for women

Lack of professional courses

Lack of electricity and water

Suicide

Transportation problems

Lack of Bakery for women

Murder of literate women

Lack of shelter

Presence of Taliban

Government not paying attention to women

High prices

Cultural problems

Freedom and democracy

Lack of public baths

Corruption

Refused

Don't know 
Q-67. Some people say that women should have equal opportunities like men in education. Do you agree or disagree with this opinion? (Wait for response and then ask): Strongly or somewhat?

\begin{tabular}{l|c} 
Base: All respondents $\mathbf{6 4 6 7}$ & $\mathbf{( \% )}$ \\
\hline Agree strongly & 50 \\
Agree somewhat & 37 \\
Disagree somewhat & 7 \\
Disagree strongly & 4 \\
Refused & $*$ \\
Don't know & 2
\end{tabular}

Q-68. Some people say that women should be allowed to work outside the home. What is your opinion about this?

Base: All respondents 6467

Women should be allowed to work outside the home

Women should not be allowed to work outside the home

Refused

Don't know

Q-69. (ASK ALL) Do you think that political leadership positions should be mostly for men, mostly for women, or do you think that both men and women should have equal representation in the political leadership?

\begin{tabular}{l|c}
\hline Base: All respondents $\mathbf{6 4 6 7}$ & $\mathbf{( \% )}$ \\
\hline Mostly for men & 40 \\
\hline Mostly for women & 11 \\
\hline Equal for both men and women & 46 \\
\hline Other & $*$ \\
\hline Refused & $*$ \\
\hline Don't know & 2
\end{tabular}

Q-70. Are you opposed to a woman representing you in the following organizations?

Base: All respondents 6467

\begin{tabular}{|c|c|c|c|}
\hline Yes & No & Ref. & DK \\
\hline $\mathbf{( \% )}$ & $\mathbf{( \% )}$ & $\mathbf{( \% )}$ & $\mathbf{( \% )}$ \\
\hline 49 & 49 & $*$ & 1 \\
\hline 47 & 51 & $*$ & 2 \\
\hline 43 & 55 & $*$ & 2 \\
\hline 41 & 56 & $*$ & 2 \\
\hline 41 & 56 & $*$ & 2 \\
\hline
\end{tabular}

a) In National Parliament

b) In your Provincial Council

c) In your Community Development Councils

d) In your District Development Assembly

e) In your local Shura or Jirga

$\%)$
0
7
7
4
$*$
2




\section{DEMOGRAPHICS}

\section{D-1. Gender}

\begin{tabular}{|l|c|c|}
\hline & Base: All respondents $\mathbf{6 4 6 7}$ & $\mathbf{( \% )}$ \\
\hline Male & & 56 \\
\hline Female & 44 \\
\hline
\end{tabular}

D-2. (Ask All) How old were you on your last birthday? (Record actual age; if respondent refuses, please estimate)

\begin{tabular}{|c|c|}
\hline Base: All respondents 6467 & $(\%)$ \\
\hline 18-24 Years old & 26 \\
\hline 25-34 Years old & 27 \\
\hline 35-44 Years old & 23 \\
\hline 45-54 Years old & 14 \\
\hline Over 65 years & 10 \\
\hline
\end{tabular}

D-3. Are you now working, a housewife (ask only women), retired, a student, or looking for work?

\begin{tabular}{|l|c|c|} 
& Base: All reposndents $\mathbf{6 4 6 7}$ & $\mathbf{( \% )}$ \\
\hline 1 Working & & 44 \\
2 Retired & 1 \\
3 Housewife & 39 \\
\hline 4 Student & 7 \\
\hline 5 Unemployed & 9 \\
\hline
\end{tabular}

D-4. (Filtered. Ask if working or retired): What is your main occupation? (Write down and then code. If retired, ask for previous occupation and then code)

Occupation:

\begin{tabular}{|l|c|}
\multicolumn{1}{|c|}{ Base: Working or retired 2883 } & $\mathbf{( \% )}$ \\
\hline 1 Farmer (own land / tenant farmer) & 34 \\
2 Farm laborer (others' land) & 13 \\
3 Laborer, domestic, or unskilled worker & 6 \\
\hline 4 Informal sales/ business & 10 \\
\hline 5 Skilled worker/artisan & 10 \\
6 Government Office - Clerical worker & 3 \\
7 Private Office - Clerical worker & 1 \\
8 Government Office - Executive/ Manager & 1 \\
9 Private Office - Executive/ Manager & $*$ \\
10 Self employed Professional & 9 \\
11 Small business owner & 5 \\
12 School Teacher & 5 \\
13 University Teacher & $*$
\end{tabular}


14 Military/ Police

15 Don’t know

D-5. (Filtered. Ask if "Farmer", code '1' in D-4) How much land do you farm?

\begin{tabular}{|c|c|}
\hline Base: All respondents 6467 & $(\%)$ \\
\hline Less than 1 Jerib & 8 \\
\hline 1 - 2 Jerib & 21 \\
\hline 2.1- 3 Jerib & 29 \\
\hline More than 3 Jerib & 39 \\
\hline Don't know & 3 \\
\hline
\end{tabular}

D-6. (ASK ALL) What is the highest level of school you completed? (Write down response and code)

Education :

Base: All respondents 6467

$(\%)$

Never went to school

Primary School, incomplete (classes 1 to 5)

Primary School, complete (finished class 6 )

Secondary education, incomplete (classes 7 to 8)

Secondary education, complete (finished class 9)

5

High School (classes 10 to 12)

\section{4}

University education or above

3

Refused

Don't know

D-7. Which languages can you speak? (Multiple response. Code each mentioned)

\begin{tabular}{|c|c|}
\hline Base: All respondents 6467 & $(\%)$ \\
\hline Pashto & 29 \\
\hline Dari & 36 \\
\hline Uzbeki & 2 \\
\hline Turki & 1 \\
\hline Urdu & 2 \\
\hline Hindi & * \\
\hline English & 6 \\
\hline Arabic & 2 \\
\hline Russian & $*$ \\
\hline Other & $*$ \\
\hline Cant read & 59 \\
\hline
\end{tabular}


D-8. Are you married or single?

\begin{tabular}{l|c|c|} 
& Base: All respondents $\mathbf{6 4 6 7}$ & $\mathbf{( \% )}$ \\
\hline Single & 19 \\
\hline Married & 78 \\
\hline Widower/ Widow & 2 \\
\hline
\end{tabular}

D-9. Which ethnic group do you belong to? SINGLE RESPONSE ONLY

\begin{tabular}{|c|c|}
\hline & $(\%)$ \\
\hline Pashtun & 42 \\
\hline Tajik & 31 \\
\hline Uzbek & 9 \\
\hline Hazara & 10 \\
\hline Turkmen & 2 \\
\hline Baloch & 1 \\
\hline Kirghiz & * \\
\hline Nuristani & 1 \\
\hline Aimak & 2 \\
\hline Arab & 2 \\
\hline Pashaye & * \\
\hline
\end{tabular}

D-10. (Ask All) How many people live here at this address? (Record Number Below)

\begin{tabular}{|c|c|}
\hline Base: All respondents 6467 & $(\%)$ \\
\hline 1-5 persons & $1 \backslash 2$ \\
\hline 6-7 persons & 20 \\
\hline 8-9 persons & 25 \\
\hline $10-11$ persons & 19 \\
\hline Over 12 persons & 25 \\
\hline Refused & $*$ \\
\hline
\end{tabular}

D-11. (ASK ABOUT BOTH MALES AND FEMALES) Would you tell me how many men/women are there in your household and how old is each of them? [INTERVIEWER: Write number of people for each category] 


Base: All male $\mathbf{3 5 9 7}$
$0-5$
$6-10$
$11-17$
$18-29$
$30-44$
$45-60$
$61+$
Total
Refused
Don't Know

Base: All female 2870

0-5

6-10

11-17

18-29

30-44

45-60

$61+$

Total

Refused

Don't Know

D-12a. For statistical purposes only, we need to know your average monthly household income. Will you please tell me which of the following categories best represents your average total family monthly income? (Show Card and read out)

\section{Base: All male 3597}

Less than 2,000 Afs

$2,001-3,000$ Afs

$3,001-5,000$ Afs

5,001 - 10,000 Afs

$10,001-15,000 \mathrm{Afs}$

$15,001-20,000$ Afs

20,001 - 25,000 Afs

25,001 - 40,000 Afs

more then 40,000 Afs

Refused

Don't know

D-12b. Do female members of the family contribute to this household income?

\begin{tabular}{|l|c|}
\hline Base: All respondents $\mathbf{6 4 6 7}$ & $\mathbf{( \% )}$ \\
\hline Yes & 16 \\
\hline No & 84 \\
\hline
\end{tabular}


Refused

Don't know

D-12c. [ASK IF YES AT D-13b] How much of your household's total income comes from female members of the household?

\begin{tabular}{l|c|}
\hline Base: Female members of the family contributes to Household & (\%) \\
income1022 & 57 \\
\hline Less than 25(\%) (up to one quarter) & 30 \\
\hline Between 26(\%) and 50(\%) (up to one half) & 4 \\
\hline Between $51(\%)$ and $75(\%)$ (up to three quarters) & 3 \\
\hline Between $76(\%)$ to $100(\%)$ (more than three quarters) & $*$ \\
\hline Refused & 6 \\
\hline Don't know &
\end{tabular}

D-13. (Interviewer code): Record number of people present for the interview:

\begin{tabular}{|l|c|}
\hline Base: All respondents $\mathbf{6 4 6 7}$ & $\mathbf{( \% )}$ \\
\hline Two & 30 \\
\hline Three & 41 \\
\hline Four & 19 \\
\hline Five & 6 \\
\hline Six & 2 \\
\hline Seven & 2 \\
\hline Eight & $*$ \\
\hline Nine & $*$ \\
\hline Ten and more than ten & $*$ \\
\hline
\end{tabular}

RECORD THE TIME (USING 24 HOUR CLOCK) INTERVIEW WAS COMPLETED AND THE LENGTH OF THE INTERVIEW (M-15 AND M-16)

\section{Read Closing Statement to the Respondent:}

"Thank you for participating in our survey. Do you have any questions? In the next few days my supervisor may contact you to evaluate the quality of my work and answer any other questions you may have. To help him do that, could I have your name and address?"

\section{Respondent Information:}

Name:

Address: 
"I certify that I have completed this interview according to the instructions provided me by the Afghan Center for Socio-economic and Opinion Research.

Signed

Date

D-14. (Interviewer code): Code household status. Based on your impressions from the dwelling of the household, the environment, the appearance of its members, please rate the living standard of this household:

Base: All respondents 6467
The household is well-off; its standard is by all accounts well
above the average
The household is enjoying a fair well-being, but generally, the
features of luxury are missing, they are not rich
The household is not denying itself the most important, vital
goods of life, but the environment bears indications of moderate
existence; they can't indulge in any excesses
The household is not denying itself the most important, vital
goods of life, but the physical infrastructure of the household is
in bad condition or in need of repair
Property-wise the household is more or less OK, but there is an
apparent problem with incomes; they are obviously surviving and
living with difficulty
The household bears all signs of poverty; living in misery, with
privations

D-15. (Interviewer code): Which of the following statements do you think best describes the level of comprehension of the survey questionnaire by the respondent?

$\begin{array}{lc}\text { Base: All respondents } \mathbf{6 4 6 7} & (\mathbf{\%}) \\ \text { The respondent understood all of the questions } & 66 \\ \text { The respondent understood most of the questions } & 27 \\ \begin{array}{l}\text { The respondent understood most of the questions but with some } \\ \text { help }\end{array} & 6 \\ \begin{array}{l}\text { The respondent had difficulty understanding most of the questions, } \\ \text { even with help from me }\end{array} & 1\end{array}$


D-16. (Interviewer code): Which of the following statements best describes the level of comfort or unease that the respondent had with the survey questionnaire?

Base: All respondents 6467

The respondent was comfortable (at ease) with the entire questionnaire

The respondent was comfortable with most of the questions

The respondent was comfortable with only some of the questions

The respondent was generally uncomfortable with the survey questionnaire

\section{To Be Completed By The Supervisor:}

D-17. Was the interview subject to quality control/back-check?

1. Yes

2. No

D-18. Method of quality control/back-check

1. Direct supervision during interview

2. Back-check in person by supervisor

3. Back-check from the central office

4. Not applicable 


\section{Appendix 4 : Afghanistan Provincial and Regional map-Direction of the country}

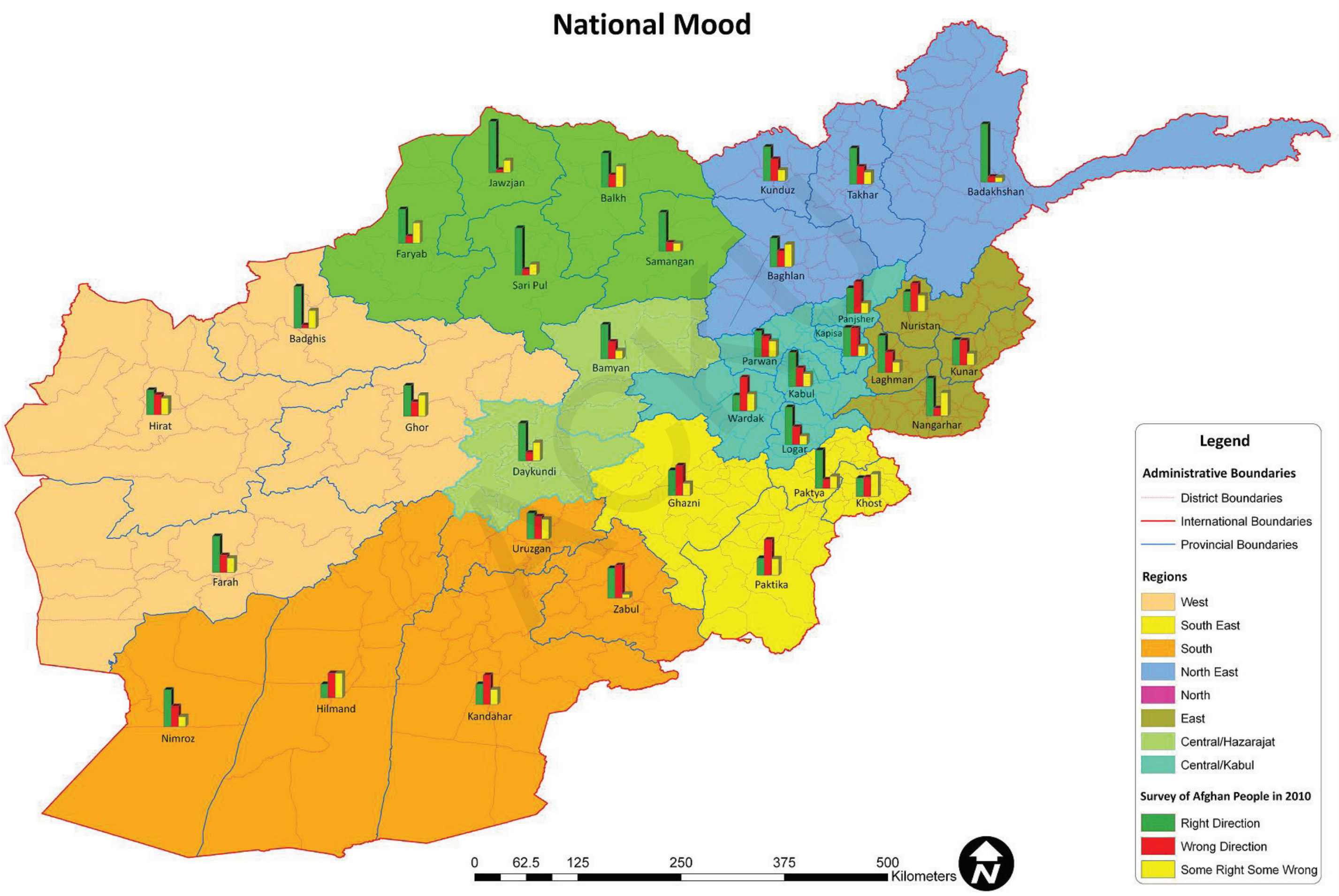




\section{Q The Asia Foundation}

House \# 48 \& 50 • Street No. 1, Hajji Yaquob Square, Kabul, Afghanistan

www.asiafoundation.org
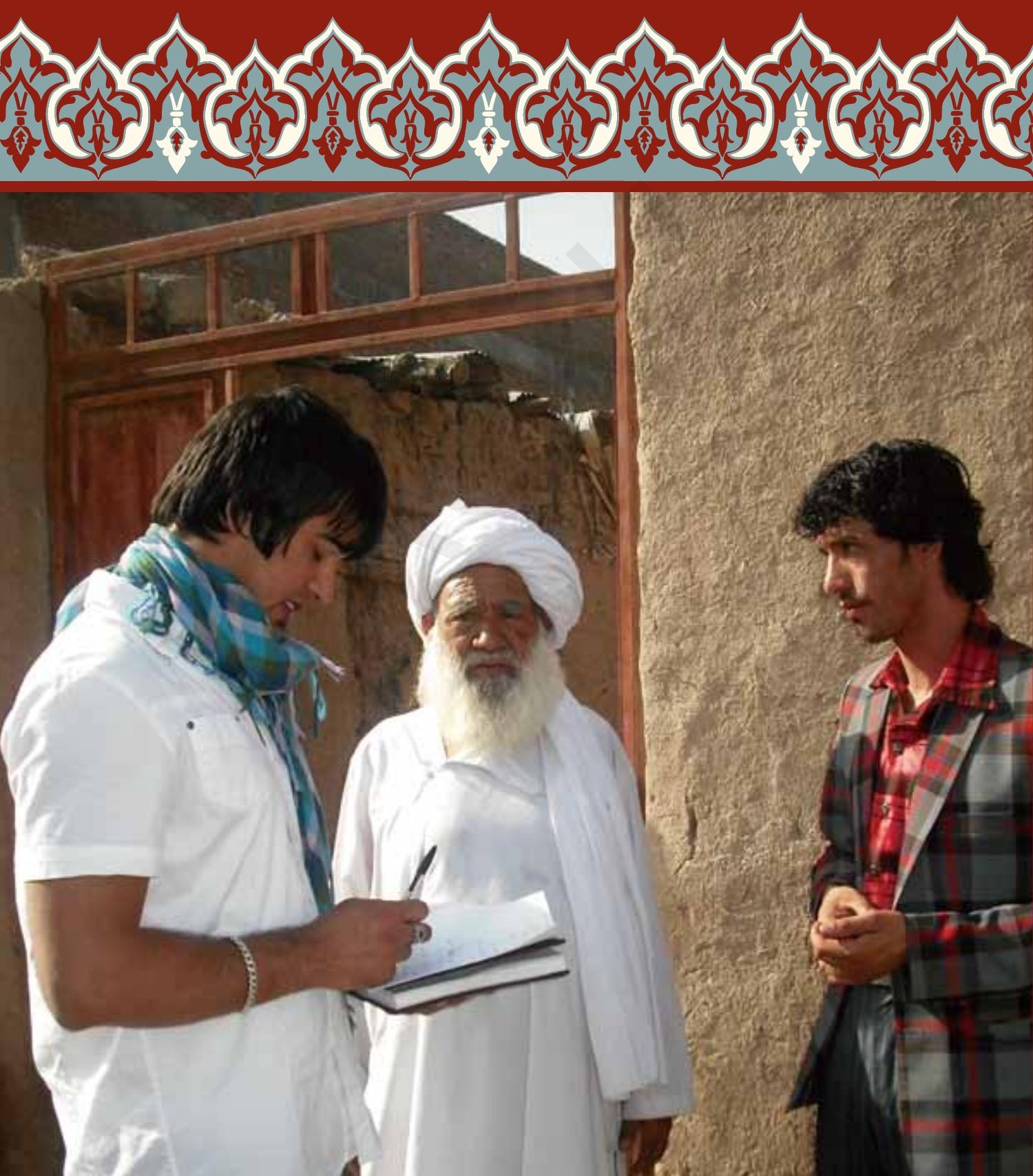